Historic, Archive Document

Do not assume content reflects current scientific knowledge, policies, or practices. 


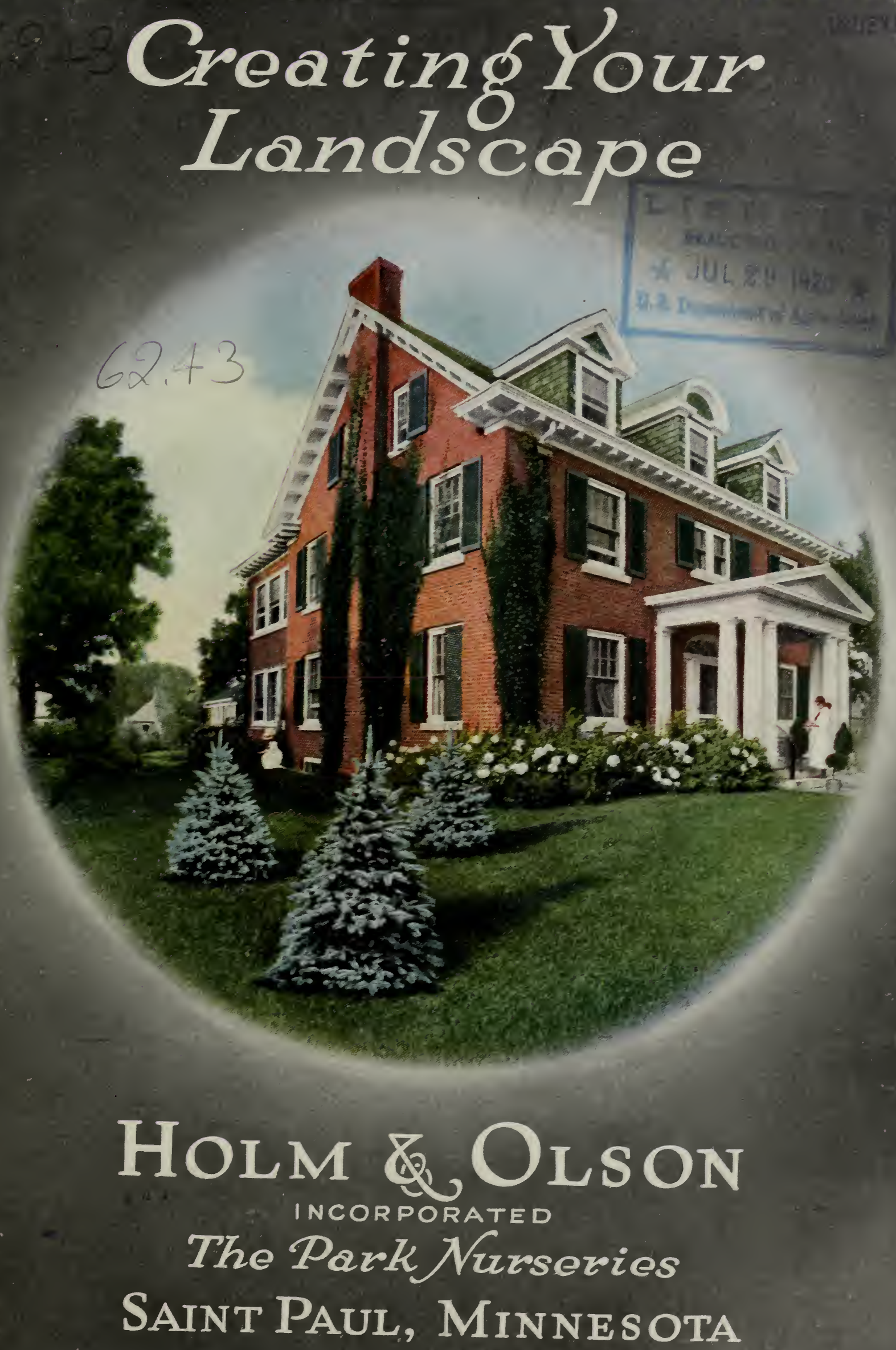




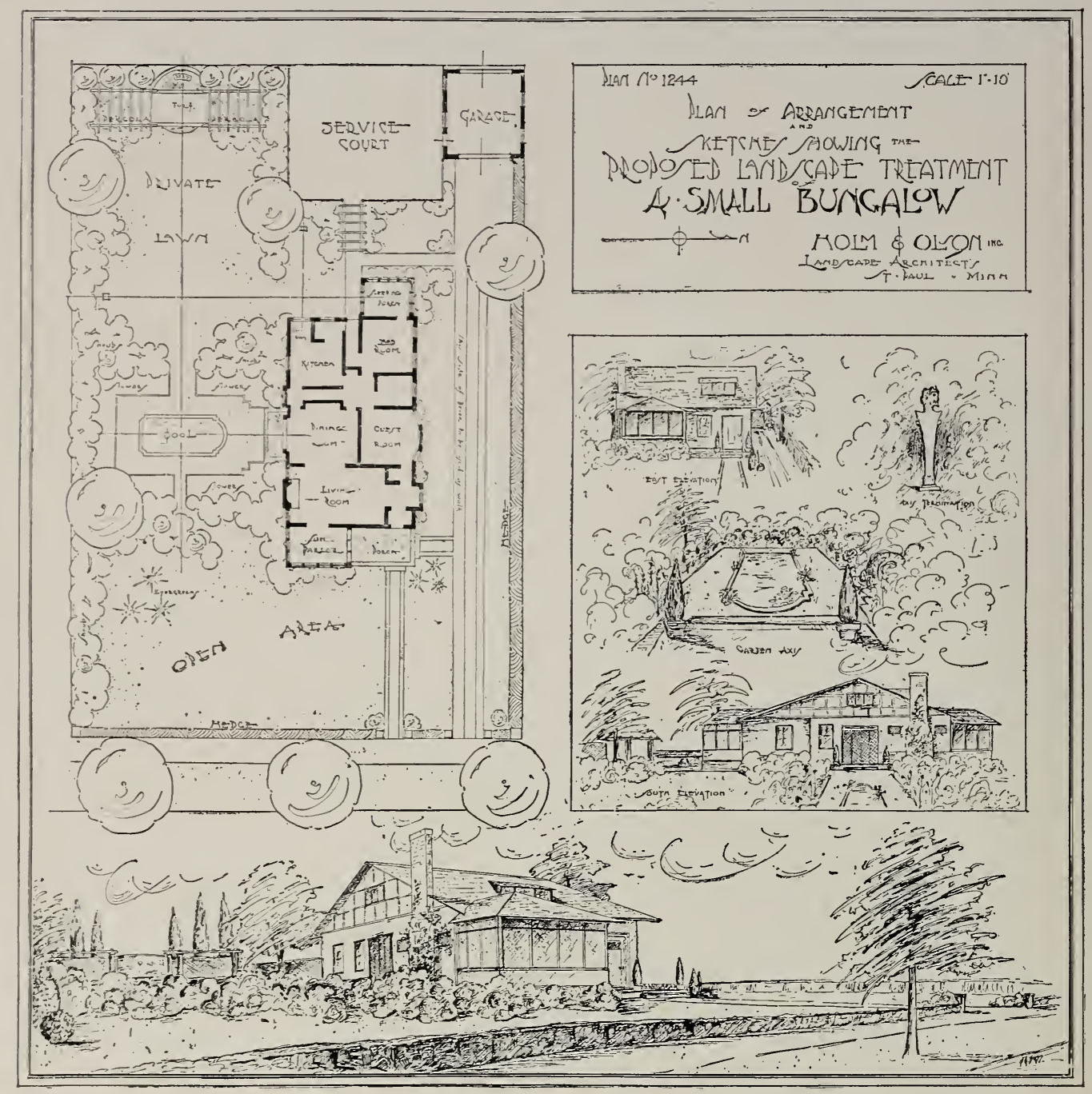

Prospective plan for small grounds, designed by the $H$. of $O$. Service

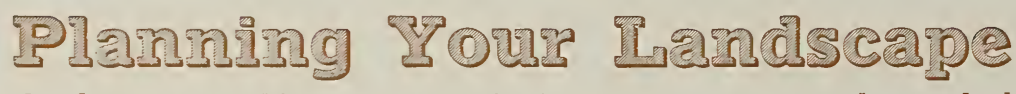

An attractively planted ground in any community is a force that cannot be overlooked; it has a tendency to make people desire to live in such a neighborhood, and also to increase property values. The beauty of the house does not lie wholly in the architectural design, the building can be made to do its part in the completed picture only when set in the proper surroundings. Too of ten the owner forgets this when arranging the landscape, and the result is unattractive. The planting about the bungalow and the colonial house must be entirely different, and designed to harmonize with the architecture.

A Landscape Plan. Every landscape proposition should have a plan. The beauty of a planting does not depend so much on the trees or plants used as it does on having them properly located, having in mind making the grounds look Iarger than they really are, with a broad, open lawn, keeping the planting around the outside borders. Another important object is the use of proper material about the foundation "to pin the house to the ground," and work out a solution for the service portion of the premises so you may have the necessary privacy.

The Cost of Planning. We make no charge for the plans where we furnish the material for the planting. It is understood, however, that where we send you the blue-prints you are charged 10 per cent of the cost of the material. If the material for the planting amounts to $\$ 100$, we charge you $\$ 10$ for the plans; if the material amounts to $\$ 500$, we charge you $\$ 50$ for the plans. This is credited to you on your order when booked. The making of the plans "free of charge" is a part of the "H. \& O. Service" but we find it necessary to protect ourselves.

Cost of Material. We grow and furnish the best material that can be secured, delivered on board cars at St. Paul. We do not enter competitions either in Iandscape work or in the sale of the material. We offer you a "service" that is not maintained by any other frrm in the West. We plan and design your grounds free of charge; furnish you with the material grown in our own nurseries; furnish you with a competent landscape gardener who superintends the planting, so that everything will be correctly planted. We guarantee satisfactory results, and will replace any trees or shrubs that fail to grow when planted by our employees.

H. \& O. Service. Write us at once for charts showing how to take measurements, giving the exact Iocation of your house on the lot. With these measurements, and photographs, we can arrange your planting. If the grounds are large, and you need advice as to grading, walks, drives, etc., then it will be necessary to make a personal visit. Our Iandscape men are on the road most of the year, and by writing us in advance we can arrange to have them caIl; but when special trips are necessary we charge for the service and the expenses.

LECTURES. - Civic clubs and improvement societies may arrange with us for illustrated lectures on landscape gardening and similar topics. Write us, telling the character of the meeting, and what is desired. 


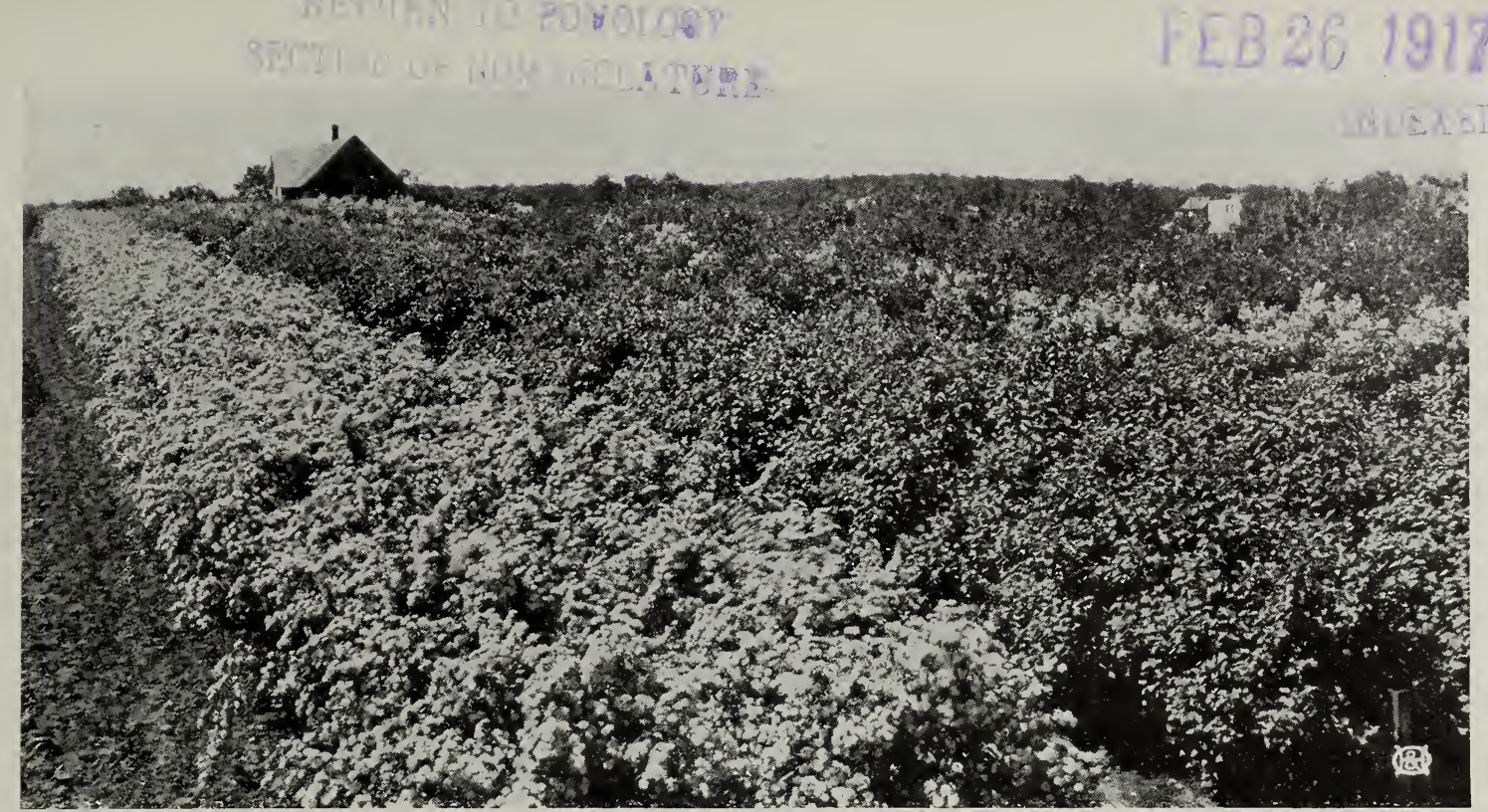

Notice the size of the Spireas that we can furnish. Such plants are effective from the very first

\section{The Park Nurseries}

Just on the border of the residence section of St. PauI, and adjacent to the boulevard that connects the Twin Cities, are the frelds and packing-grounds of The Park Nurseries. It was a happy thought that induced the founders of the business to select a location convenient to both cities, for the Nurseries are extremely interesting to our friends who desire to know the trees, shrubs and plants that are hardy in this section. It was important also that the Nurseries be located nearby, so that the large specimen trees and shrubs could be transplanted quickly, thus insuring safe growth and effective appearance from the very beginning.

How to Reach the Nurseries

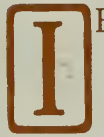

toring or driving, use Lexington Avenue, south of Summit, to St. Clair Street.

From any down-town point take St. ClairHope car. This line takes you within two blocks of the Nurseries. Coming from Minne- apolis, use either Como-Harriet, St. Paul-Minneapolis, or Selby-Lake lines, transferring at Snelling Cross-town to the Grand Avenue line; get off at Lexington Avenue, and walk south to St. Clair Street.

We invite aII patrons, as well as all prospec-

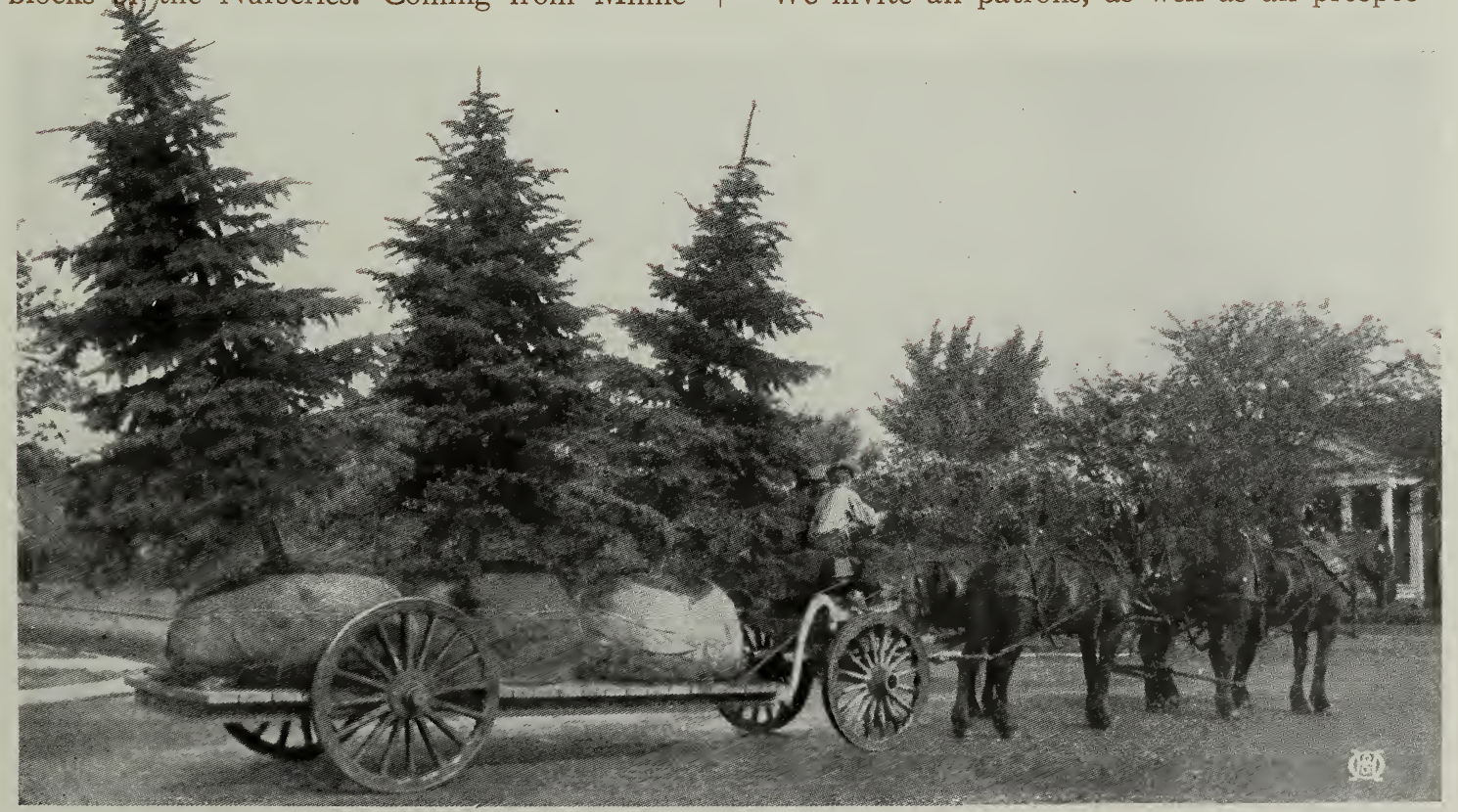

Big trees on the way to the grounds of the Overland automobile factory. See next page 
tive patrons, to pay us a visit and become better acquainted with "Quality" stock, to see how the trees, shrubs and plants are grown, to get an idea how they will appear in their own grounds. Our superintendent will be pleased to explain or give any information relative to the hundreds of varieties of trees, shrubs and plants we grow.

Most nursery goods are bought without seeing them, or having an idea of their value, therefore, one of the important features of having a nursery near home is the certainty that whatever you buy is suited to this section and is acclimated. Many get the idea that trees and plants are kept in cold storage. Here at the nursery you see them as they are growing. You can make your selection, knowing the sizes, and you have no disappointments. Many of our customers travel hundreds of miles to make their selections, that they may know how certain trees and bushes will look when they are transplanted. Hence, at your door is located a nursery producing just what thousands of persons building new homes are looking for.

\section{The Home Gounds}

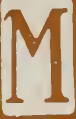

SSIVE marble walls, ornate carvings and elaborate architectural efforts do not, by any means, make an attractive public building nor an inviting home. There seems to be a lack of harmony with the surround- ings, the sense of restfulness and comfort is disturbed, and you instinctively turn away to a more pleasing view of the grounds that are adorned with grass and trees and shrubs.

The colonial houses of New England owe fully as much of their beauty to their surroundings as to the lines of the buildings. Without the clinging vines, the boxwood hedges, the old-fashioned flowering shrubs and the wide arches of the elms, they would lose much of their quaint beauty.

The grass, the shrubs, the trees, the flowers, have a distinctive value in the landscape, and through their use alone can the conception of the architect and the builder be brought out and developed to the utmost. The combined effect makes the imposing public building, the stately mansion and the home-like cottage. Some of the most pretentious homes fail to arouse admiration solely because the trees and shrubs do not harmonize with the perspective lines of the houses, or because the plants do not harmonize with each other; some of the most desirable and beautiful plants may not have a proper setting and therefore cannot exhibit their full beauty. One may have a perfect lawn, rare trees and shrubs, with a splendid collection of plants, yet destroy the effect of the complete planting by a careless or unwise arrangement.

Another important thing for the home-owner to consider is that a well-arranged landscape plan

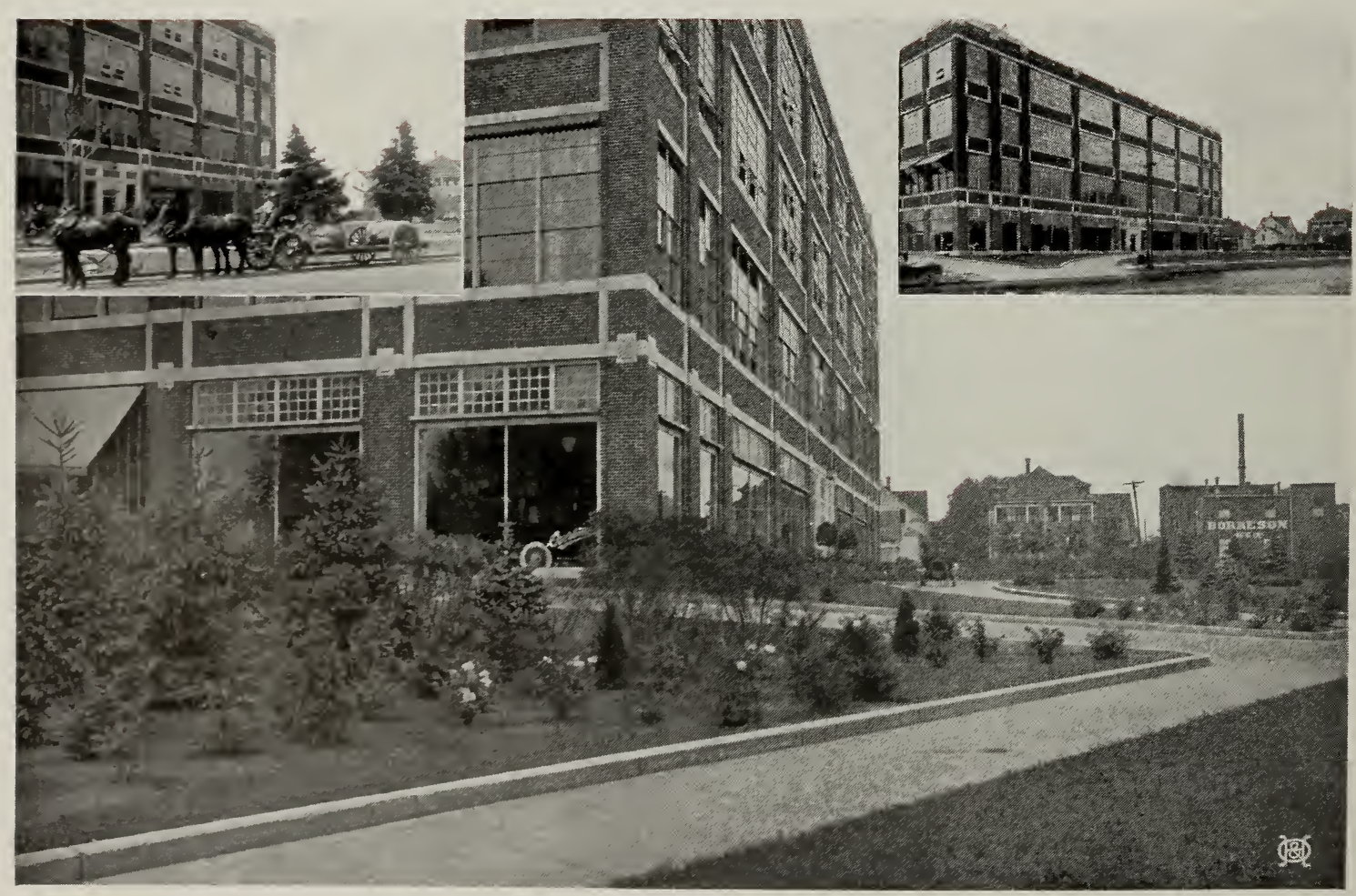

This illustration shows the Overland factory before and after the H. of O. Service planned the surroundings 

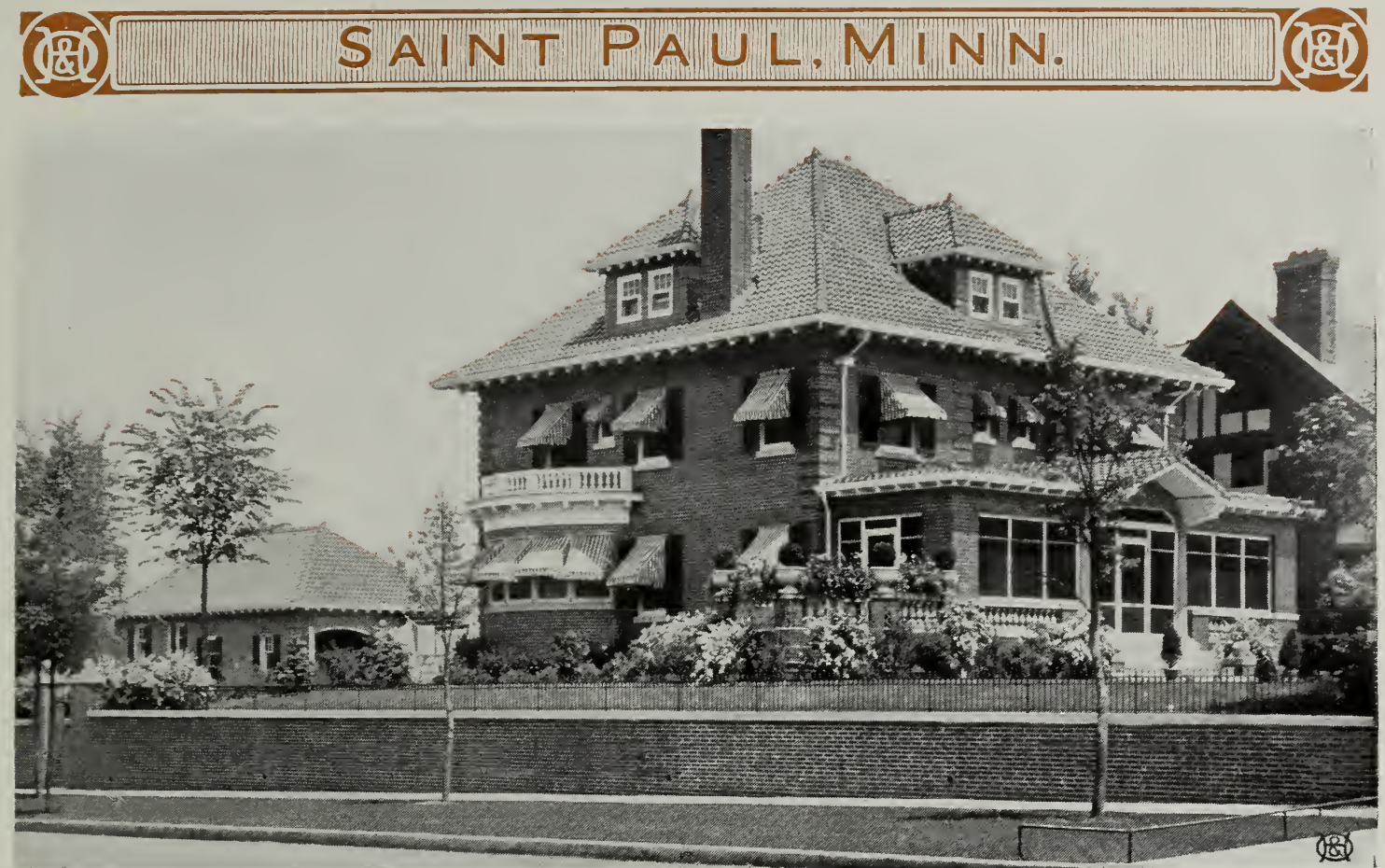

The retaining wall, topped with an artistic railing, and the pleasing shrub planting, give a distinct appearance of privacy

adds to the actual value of the property far more than the cost of the trees and shrubs plus the labor of planting. It is a well-known fact among real-estate men that an expenditure of $\$ 50$ or $\$ 100$ in evergreens, shade trees and flowering shrubs will increase the selling price of the property from $\$ 300$ to $\$ 500$; and the purchaser pays the price willingly, for the flowers and shade in summer, with the deep green evergreens breaking the expanse of snow in winter, appeal to his sense of beauty and fitness.

\section{You Should Have Your Grounds Planned}

W HETHER you are building a home and need planting plans prepared from the beginning, or whether you simply want to rearrange what has already been done, we are at your service with practical suggestions and facilities for executing these plans in a thoroughly satisfactory manner.

Several years ago we saw that if the best results were to be secured from our trees and shrubs it would be necessary to supply suitable plans for planting, and so the H. \& O. landscape Service was organized. We thoroughly believe that every landscape problem must be considered by itself; it is impossible to make one design fit every condition. The architecture of the grounds needs the same careful thought that is bestowed on the buildings, and the plan must have a definite purpose, otherwise the final result will be far from artistic and satisfactory. With a smaIl investment, and a carefully worked-out sketch, you can add a considerable sum to the value of your property. Let us show you a suggestive plan, together with an estimate of the amount needed to beautify your grounds.

Where the amount of work to be done is of considerable extent, we will lay out and design your entire grounds, beginning, if you wish, with the bare, unimproved plot of ground, and planning and superintending the grading. We will give the proper setting to the sun-dial and pergola, design and locate the entrance, etc.; we will locate trees, shrubs and plants, and design the garden.

\section{Plantings That Fit}

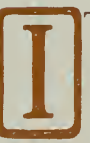

$\mathrm{T}$ is on an unimproved plot of ground that the Iandscape designer's ability shows to the best advantage. In a city's great park, or on the large estate, he has money at his disposal, material to draw from, and almost unlimited possibilities. But around the home grounds he must be governed by the space, the surroundings and a limited sum of money. Here is his opportunity-will he rise to it, or will the result be only ordinary? That our organization has proved itself competent in landscape work is shown by the illustrations in this book, which are views of our plantings in and about St. Paul and adjoining territory.

In addition to and supplementing our work as landscape architects, we are growing trees, plants and shrubs that succeed in this locality, and knowing these thoroughly is part of our business. Our understanding of how they should be 
arranged for proper effects is worth a great deal to our clients, and it is freely at the command of those who engage our services.

Our advice means much to your success. We tell you if you should not plant a certain thing, when it is not hardy or where it would not suit. Use our Service; we are glad to advise and assist those who do not know, or who have not studied tree and plant life, and show them how to plant, when to plant, and what to plant.

\section{The H. \& O. Service}

[] $T$ is not necessary, under our system, to purchase plans for your grounds, for we complete the entire work. Many landscape architects sell their plans, charging for this service of designing the grounds. Under such conditions it is necessary to purchase trees, shrubs, plants, etc., from another source, and secure the service of someone else to plant. If, for any reason, the results are not to your liking, it is the fault of the one supplying the stock or of the man who planted it. Our Service does away with all responsibility; no one is to blame but ourselves if results are not satisfactory.

Located close by the St. Paul Hotel, the H.\& O. Stores are known throughout the country as "The Home of Flowers," the Iargest flower-stores in America, as well as the best-arranged and most beautiful interiors. This part of our business

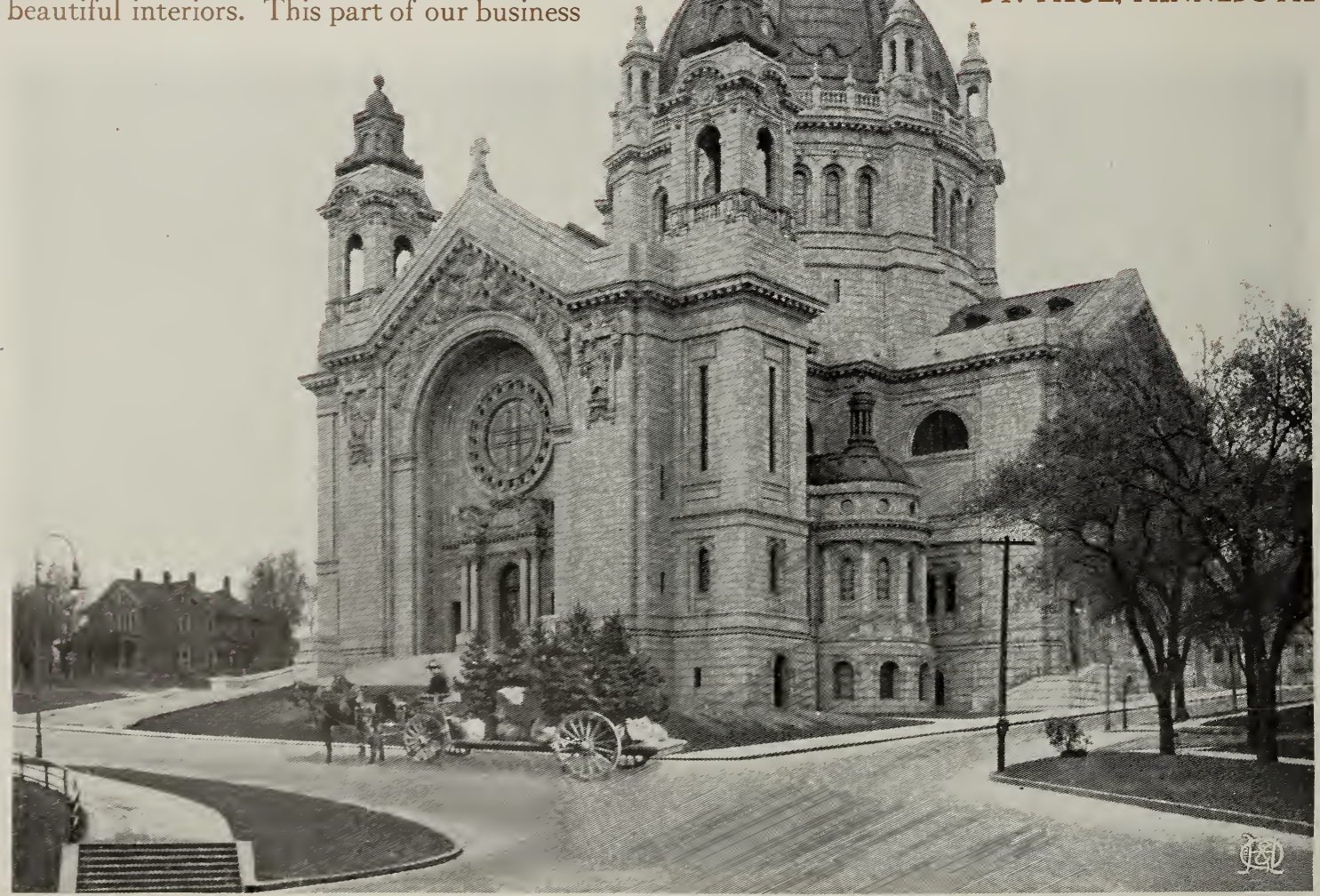

The magnificent St. Paul's Catbedral-one of the most imposing edifices in the northwest. The H. 0 O. Service bas just begun the planting about the grounds, and the beauty of the building will be greatly emphasized by the evergreens and sbrubs to be set around the foundation. had a small beginning, but Quality and Service give us the distinction we hold today. These essential principles, so successful in the flower business, have been used in our Nursery and Landscape Business, but to a greater degree, our earlier experience having given us valuable knowledge.

Quality in any commodity creates demand. Quality plus Service, and especially in this business, does away with failure when one does not know nor have experience. We design your grounds; tell you what will harmonize with the building and lot; experienced men, who know how it should be done, do the planting, and give you results that are pleasing, and make you a friend, all of which helps develop our business. If you are undecided what to plant or where to plant it, we furnish the information, also arrange the planting so that it fits that particular part of the grounds. We not only do the planting so that you have something in bloom at all seasons, but so that you have a variety in foliage of different shades.

\section{HOLM \& OLSON, Inc.} The Park Nurseries 20-24 WEST FIFTH STREET ST. PAUL, MINNESOTA

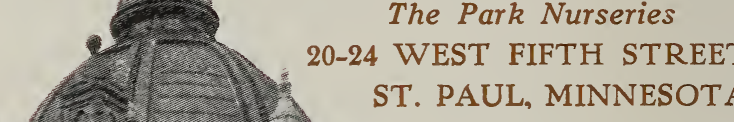




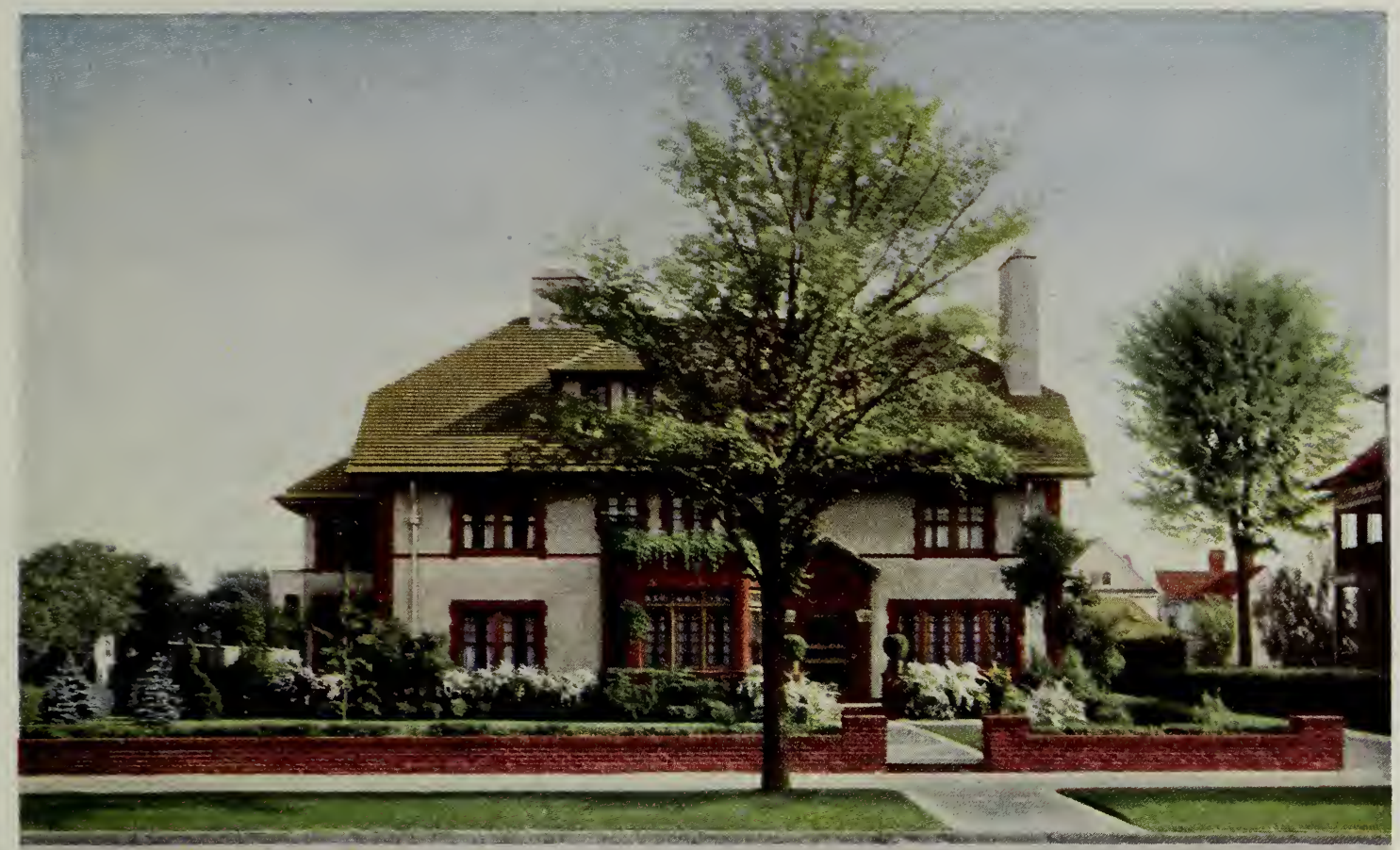

A distinctive arrangement of shrubs around the bome of Mr. E. N. Saunders, Jr., Summit Avenue

\section{ORNAMENTAL TREES}

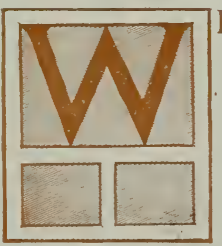

E strongly urge the importance of the proper preparation of the soil before planting. The usual method practised by many planters is to dig holes much too small for the tree that took years to grow; if this is done, its life is cut off or the growth is checked. With the acknowledgement of each order we send instructions how to plant and prune and care for the trees.

Transplanted Trees. The question is often asked, "What do you mean by Transplanted Trees?" Just this: We are not what is termed a "Commercial Nursery;" we grow nursery stock from a landscape standpoint, making a specialty of ornamentals for beautifying city and country homes. We transplant our trees and shrubs into nursery rows, setting them twice and three times the usual distances apart, cutting them back to make them put on a bushy head and heavier stem, and, most important, a better root-system. Such nursery stock withstands the shock of transplanting much better than the ordinary, and responds much more quickly.

What Are Specimen Trees? Specimen trees are selections that have been transplanted from time to time, have grown into large sizes, and can be moved safely, giving quick results. Ordinarily, large trees in a nursery are "culls" left over, or unsold; but, having never been transplanted, they are of Iittle or no value.

Alder, European (Alnus glutinosa). Foliage roundish, wedge-shaped, wavy. Quick grower. 30 to 60 feet high.

5 to $6 \mathrm{ft}$.

6 to $8 \mathrm{ft}$.

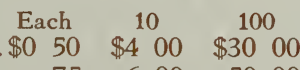

8 to $10 \mathrm{it.}, 11 / 2$ in. diam., transplanted.......... $125 \quad 1000 \quad 8000$ 10 to $12 \mathrm{ft.}, 2$ in. diam., transplanted.

\section{$200 \quad 1800$}

Ash, American White (Fraxinus Americana). Our forest tree, tallest of the species, growing to 120 feet high, with straight, clean trunk, smooth gray bark and glossy leaves. Useful for parks and streets.
Prices of American White Ash Each $10 \quad 100$ 6 to $8 \mathrm{ft}$. $\$ 075 \$ 600 \quad \$ 5000$

8 to $10 \mathrm{ft} ., 1 \frac{1}{4}$ to $11 / 2 \mathrm{in}$. diam., transplanted...... $100 \quad 800 \quad 7500$

10 to $12 \mathrm{ft}$., $1 \frac{1}{2}$ to $2 \mathrm{in}$. diam., transplanted...... $150 \quad \begin{array}{lllll}50 & 12 & 00 & 100 & 00\end{array}$

10 to $12 \mathrm{ft}$., 2 to $2 \frac{1}{2} \mathrm{in}$. diam., transplanted...... $200 \quad \begin{array}{llllll} & 00 & 00 & 160 & 00\end{array}$

12 to $14 \mathrm{ft} ., 2 \frac{1}{2}$ to $3 \mathrm{in}$. diam., transplanted. ... $300 \quad 2500$

12 to $14 \mathrm{ft} ., 3$ to $4 \mathrm{in}$. diam., transplanted...... $500 \quad 4500$ Specimen trees......\$5 to 700

Box Elder (Acer Negundo). See Ash-leaved Maple, page 9. 


\section{(बien) THE PARK NURSERIES (18)}

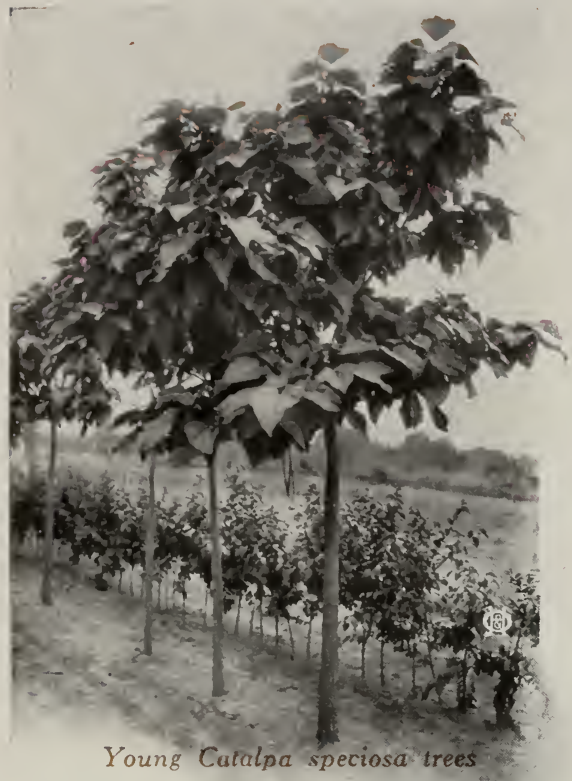

ORNAMENTAL TREES, continued

Birch, Black (Betula lutea). Yellowish gray bark, which peels off in layers; young stems have spicy taste and odor.

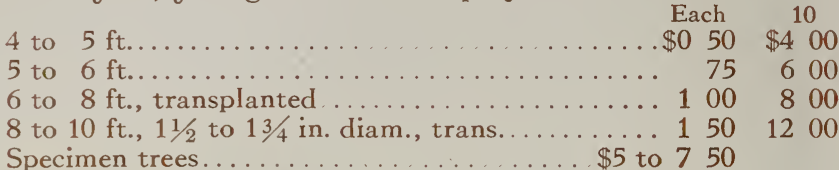

Birch, European White (Betula alba). Our native Birch; common along every roadside. Its white bark makes it attractive and very effective in groups.

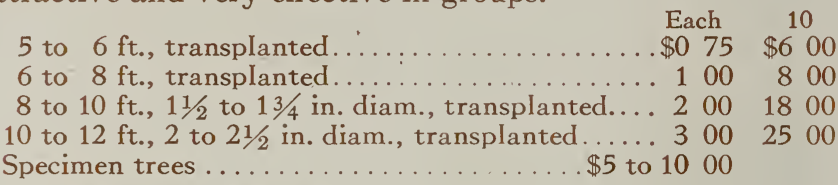

Birch, Paper or Canoe (Betula papyrifera). The brilliant white bark is wonderfully effective, particularly in winter and when planted against evergreens.

5 to $6 \mathrm{ft}$....

Each 10

6 to $8 \mathrm{ft}$, transplanted................. $150 \quad 1200$

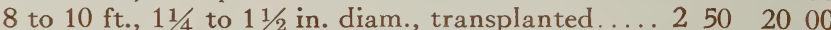

Specimen trees...................\$3 to 500

Butternut (Juglans cinerea). This lofty, spreading tree is valued for its tropical appearance, beautiful wood, and its nuts, which are large, oily and nutritious.

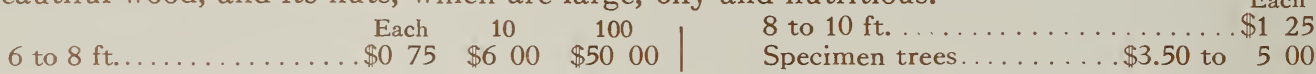

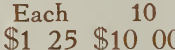

Catalpa bignonioides. Valuable for its quick growth, extreme hardiness and the beauty and fragrance of its flowers. A large tree is a magnificent sight when in full bloom. Grows to 50 feet in height under favorable conditions

6 to $8 \mathrm{ft}$., $\operatorname{trans....\$ } \$ 075 \quad \$ 600 \quad \$ 5000$

8 to $10 \mathrm{ft} ., 11 / 2 \mathrm{in}$.

diam., transplanted $150 \quad 1200 \quad 10000$

Catalpa speciosa (Western Catalpa). Well adapted for forest and ornamental planting. The coarse-grained, soft wood is durable, and useful for railroad ties, fence-posts, etc. Blooms earlier than the other varieties of Catalpa and grows to be a large tree, often becoming 100 feet high. In late summer, its great crop of Jong, narrow "beans" is very effective; the pods usually hang on the tree all winter.

$$
\begin{aligned}
& 6 \text { to } 8 \mathrm{ft} . \ldots \ldots \ldots \$ 0 \quad 50 \quad \$ 400 \quad \$ 3000 \\
& 8 \text { to } 10 \mathrm{ft} \text {., } 11 / 2 \text { in. }
\end{aligned}
$$

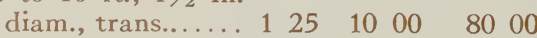

$$
\begin{aligned}
& 10 \text { to } 12 \mathrm{ft} \text {., } 11 / 2 \text { to } 2 \\
& \text { in dram., trans.... } 200 \quad 1800 \quad 150 \quad 00 \\
& 10 \text { to } 12 \mathrm{ft} \text {., } 2 \text { to } 21 / 2 \\
& \text { in. diam., trans.... } 3002500 \\
& \text { Specimen trees } \$ 5 \text { to } 2500
\end{aligned}
$$

Catalpa Bungei. Dwarf. The trees grow 10 to 12 feet high and the heads when grcwn are about 12 feet across. They grow in this shape without any trimming. The foliage is deep green, forming a beautiful roof of leaves. Each 10

2-yr. heads............ \$1 50 \$12 00

3-yr. heads, transplanted.... 2502000

Specimen trees.

500

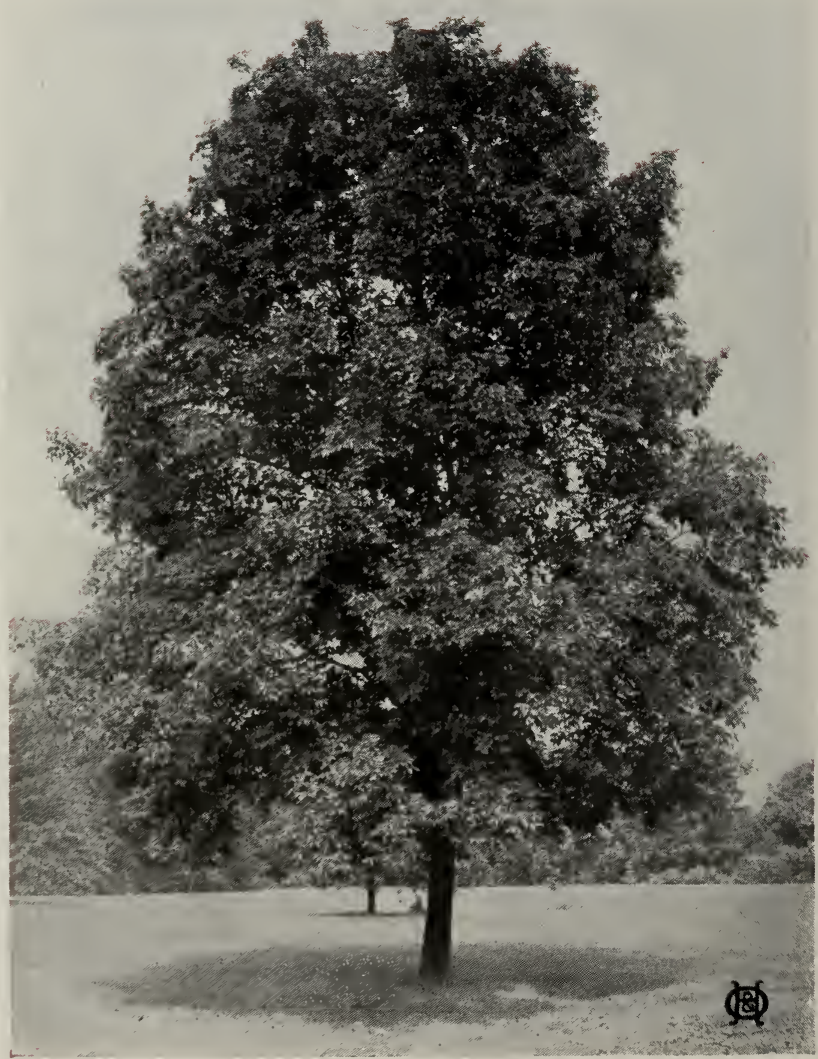

The American White Ash makes a majestic tree (see page 5) 
ORNAMENTAL TREES, continued

Cherry, American Bird (Cerasus serotina). Its flower racemes are white and fragrant; its leaves glossy and fruits black.

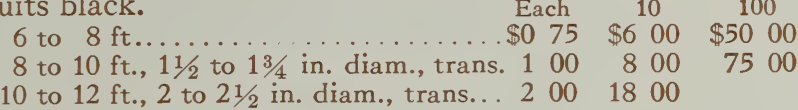

10 to $12 \mathrm{ft}$., 2 to $2 \frac{1}{2} \mathrm{in.}$ diam., trans.. . 2001800

Cherry, European (Cerasus alium flore pleno alba). In May it is covered with double blossoms, resembling roses, so numerous as to conceal the branches. A beautiful and attractive round-headed, dwarf tree.

4 to $5 \mathrm{ft}$. Each
$\$ 075$

5 to $6 \mathrm{ft}$. .

125

10 $\$ 600$

Chestnut, American (Castanea Americana). This native tree is a rapid grower. Should be closely pruned when transplanted.

4 to $5 \mathrm{ft}$.

Each 10

5 to $6 \mathrm{ft}$.

$\$ 050 \$ 400$

$75 \quad 600$

Crab, Bechtel's Flowering (Pyrus angustifolia). Seldom over 20 feet high; covered in late spring with myriads of delicate pink flowers, resembling the daintiest double roses. Blooms when quite young.

3 to $4 \mathrm{ft}$.

Each 10

$\ldots \ldots 100 \quad \$ 800$

4 to $5 \mathrm{ft}$., transplanted................. $150 \quad 1200$

Specimens ................. \$3.50 to 500

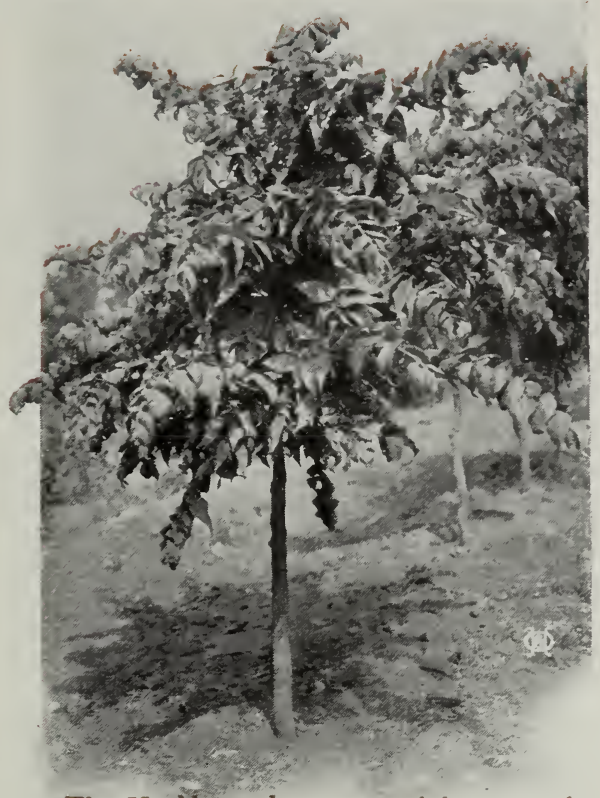

The Hackberry bas a graceful crown of broad foliage (see page 8 )

Crab, Floribunda (Pyrus floribunda). A distinct and very pretty variety, with long, slender branches. Flowers are produced in great abundance, and change from carmine to white when open Fruit small and ornamental. A splendid early-flowering tree.

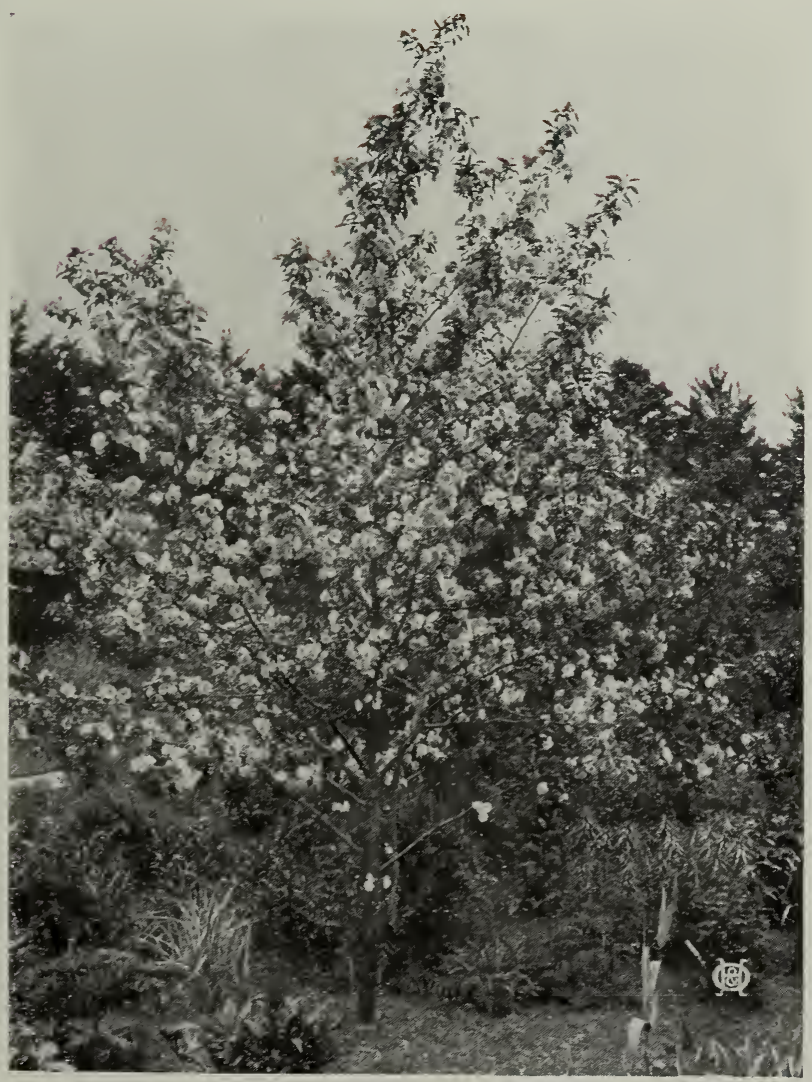

The delicate pink blossoms of Becbtel's Double-Flowering Crab are like little roses
3 to $4 \mathrm{ft}$., transplanted......\$075 $\$ 600$

4 to $5 \mathrm{ft}$., transplanted....... $100 \quad 800$

Crab, Kirkwood (Pyrus Kirkwoodii). A beautiful hardy flowering tree of the Northwest; its blossoms are fragrant, the flower is semi-double.

$$
\begin{aligned}
& 3 \text { to } 4 \mathrm{ft} \text {. } \\
& \text { \$0 } 75 \quad \$ 600 \\
& 4 \text { to } 5 \mathrm{ft} \text {. } \\
& 100 \quad 800
\end{aligned}
$$

Crab, Parkman's (Pyrus Parkmani). It flowers the whole length of the past season's growth and on the older spurs; rich carmine; double.

3 to $4 \mathrm{ft}$., transplanted......\$1 $00 \quad \$ 800$ 4 to $5 \mathrm{ft}$., transplanted........ $150 \quad 1200$

Crab, Soulard's (Pyrus Soulardii). Another beautiful native Flowering Crab. Fruit quite large, keeping until springtime, with a flavor much the same as the quince.

3 to $4 \mathrm{ft}$

Each 10

4 to $5 \mathrm{ft}$

$\$ 075 \quad \$ 600$

$100 \quad 800$

Elm, Huntingdon (Ulmus Huntingdoni). Clean, smooth bark; erect stately habit. Not so subject to attacks of insects as some kinds, and one of the very best ornamental trees.

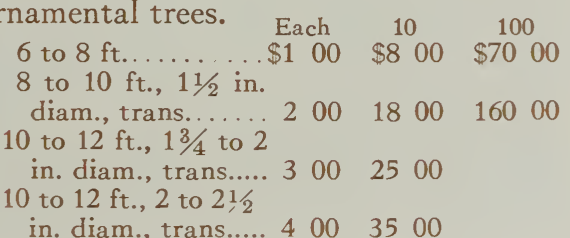




\section{ORNAMENTAL TREES, continued}

Elm, American (Ulmus Americana). The noblest and most dignified tree in the world for the street. Broad, arching branches with splendid dark green foliage, afford abundant shade. Easily grown and with wide diversity of form.

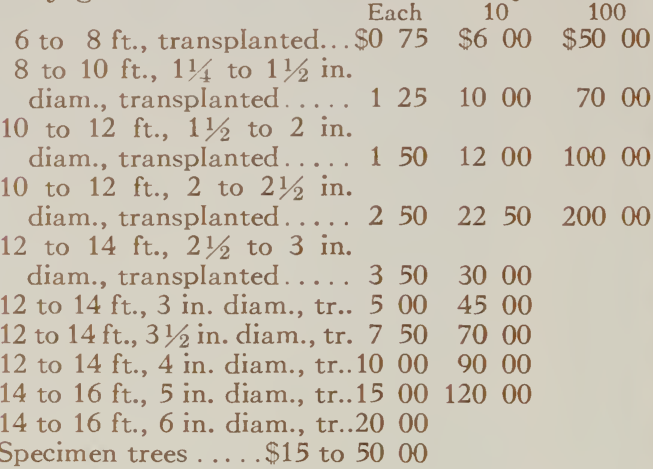

Elm, Scotch (Ulmus latifolia). A grand, spreading tree of rapid growth and variable habit. Attains a height of 100 feet and forms a broad, round-topped head.Each $\quad 10 \quad 100$

6 to $8 \mathrm{ft} \ldots \ldots \ldots \ldots \ldots$...... $\$ 075 \quad \$ 600 \quad \$ 50 \quad 00$

transplanted........... $150 \quad 1200 \quad 10000$

10 to $12 \mathrm{ft}$., 2 to $21 / 2 \mathrm{in}$.

diam., transplanted.... $300 \quad 2500$

12 to $14 \mathrm{ft} ., 3$ in. diam., tr.. 6005500

12 to $14 \mathrm{ft} ., 4$ in. diam., tr..10 009000

12 to $14 \mathrm{ft} ., 5$ in. diam., tr..15 0012500

Specimen trees....\$15 to 5000

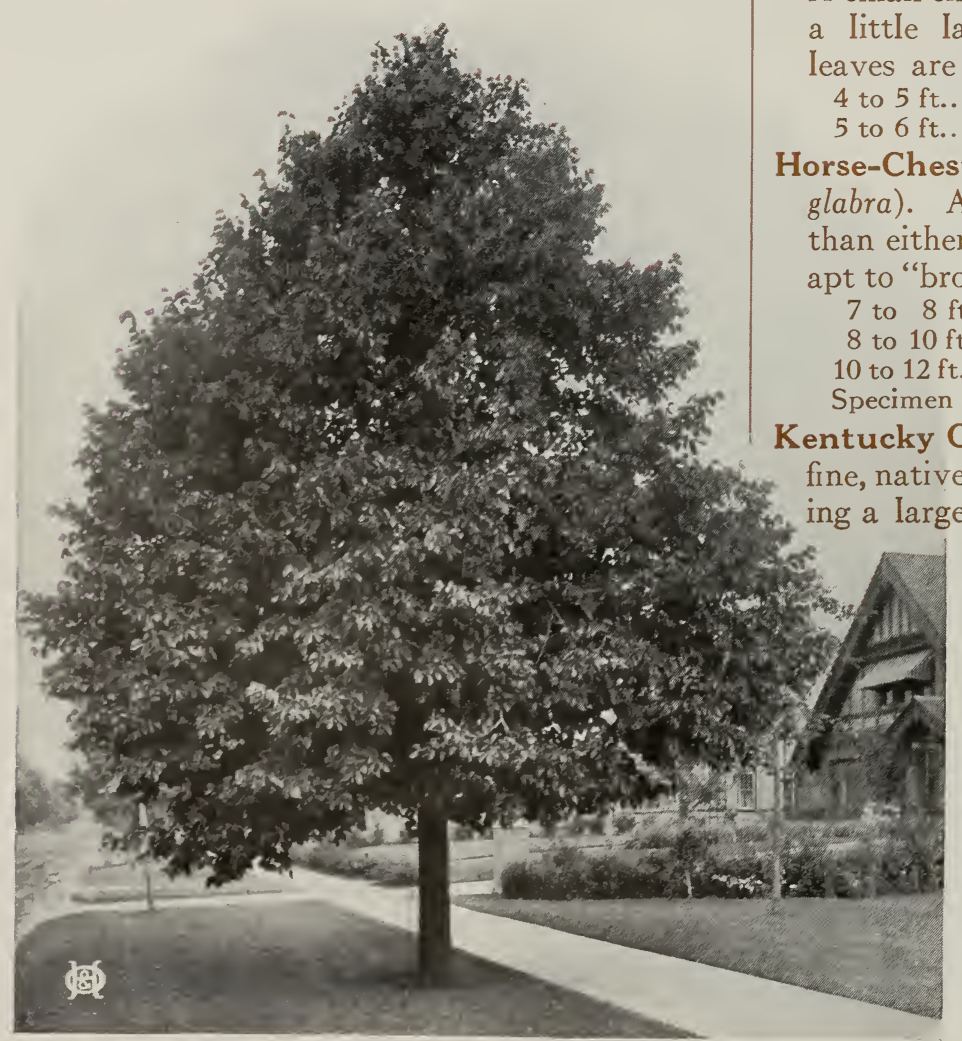

Few trees equal the American Linden for street planting (see page 9)
Ginkgo, or Maidenhair (Salisburia). A very peculiar tree both in its habit and foliage. Its leaves resemble those of the Maidenhair Fern. Its branches are rather upright but, as the tree ages, develop fully. Each 10 6 to $8 \mathrm{ft}$., transplanted......... \$1 $00 \quad \$ 800$

8 to $10 \mathrm{ft}$., transplanted.......... $150 \quad 1200$ 10 to $12 \mathrm{ft}$., transplanted, $1 \frac{1}{2}$ to $2 \mathrm{in}$.

diam.................... $300 \quad 2500$

Hackberry (Celtis occidentalis). A native tree, resembling the elm, but with rougher bark and slender branches covered with shapely pointed leaves.

6 to $8 \mathrm{ft}$.. $\begin{array}{lll}\text { Each } & 10 & 100\end{array}$

8 to $10 \mathrm{ft} ., 11 / 2$ in. diam.,

transplanted........... $150 \quad \begin{array}{lllll}50 & 12 & 00 & 110 & 00\end{array}$

10 to $12 \mathrm{ft.,} 2$ in. diam., tr.. 3002500

10 to $12 \mathrm{ft}$., $21 / 2 \mathrm{in}$. diam.,

transplanted.......... $500 \quad 4500$

10 to $12 \mathrm{ft}$., 3 in. diam., tr.. 7506500

Horse-Chestnut, White (Asculus Hippocastanum). A well-known tree with an abundance of white, fragrant flowers in May, produced in erect spikes. As a lawn tree or for the street it has no superior. Each 10

6 to $7 \mathrm{ft}$., transplanted........ $\$ 1 \quad 50 \quad \$ 1200$

7 to $8 \mathrm{ft}$., transplanted.........2 $200 \quad 1800$

8 to $10 \mathrm{ft} ., 13 / 4$ in. diam., trans... $400 \quad 3500$

10 to $12 \mathrm{ft} ., 2$ to $2 \frac{1}{2}$ in. diam., trans. 600

Specimen trees .......\$10 to 1500

Horse-Chestnut, Red (Asculus rubicunda). A small-sized tree, producing dark red flowers a little later than the preceding, and the leaves are of a darker green. Each 10 4 to $5 \mathrm{ft} . \ldots \ldots \ldots \ldots \ldots \ldots \ldots \ldots 200 \quad \$ 1800$ to $6 \mathrm{ft} . \ldots \ldots \ldots \ldots 2500$

Horse-Chestnut, Ohio Buckeye (Asculus glabra). A stronger and more rapid grower than either of the preceding. Leaves are less pt to "brown" after midsummer. Each 10

7 to $8 \mathrm{ft}$., trans. . . . . . . . . \$2 $00 \quad \$ 1800$

8 to $10 \mathrm{ft} ., 13 / 4$ in. diam., trans... . $400 \quad 3500$

to $12 \mathrm{ft}$., 2 to $2 \frac{1}{2}$ in. diam., trans. 600

entucky Coffee (Gymnocladus Canadensis). A fine, native tree of rapid, upright growth, forming a large, irregular, open specimen.

$$
\begin{aligned}
& \text { Each } 10 \\
& 6 \text { to } 8 \mathrm{ft} \text {., trans. } \$ 100 \$ 800 \\
& 8 \text { to } 10 \mathrm{ft} ., 11 / 4 \text { to } \\
& 11 / 2 \text { in. diam., tr.. } 1501200 \\
& 10 \text { to } 12 \mathrm{ft} ., 2 \text { to } \\
& 2 \frac{1}{2} \text { in. diam... } 300 \quad 2500
\end{aligned}
$$

Larch, European (Larix Europæa). An excellent, rapidgrowing, pyramidal tree, compact in growth; small branches with light green foliage, drooping in habit. Each 10 2 to $3 \mathrm{ft} \ldots \ldots \ldots \$ 0 \quad \ldots 0 \$ 400$

3 to $4 \mathrm{ft}$., trans... $75 \quad 600$

5 to $6 \mathrm{ft}$., trans... 2502000

6 to $8 \mathrm{ft}$., trans. specimens .... 500 

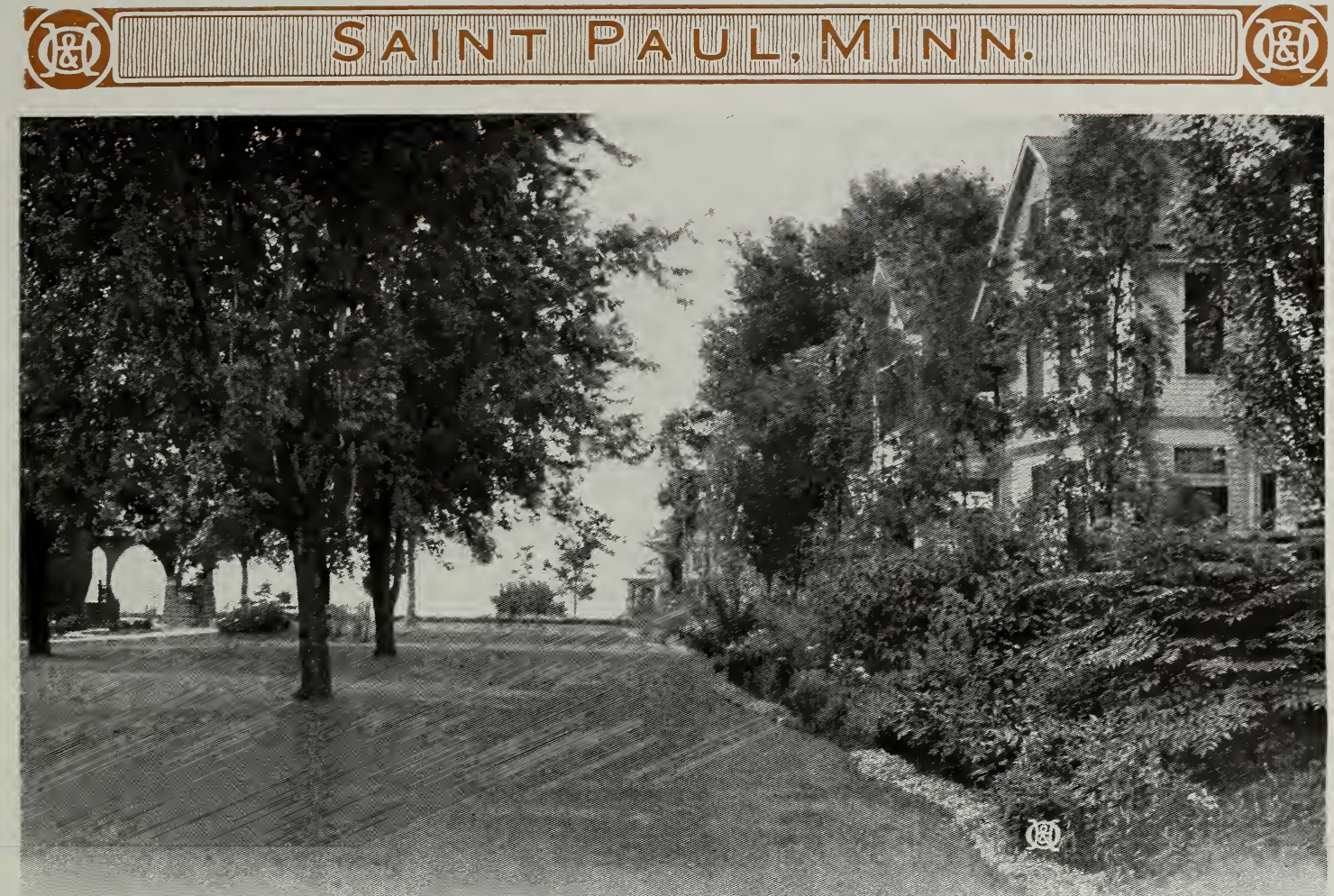

The bome of Mr. Ben Baer. The border of shrubs and perennials forms tbe frame around the grounds

ORNAMENTAL TREES, continued

Larch, Japan (Larix Kaempferi). Should be planted in moist soil. Tree of slender growth; pyramidal in form with horizontal branches; has a beautiful golden foliage in autumn. Foliage resembles that of the evergreens except that it drops in faII.

3 to $4 \mathrm{ft}$., transplanted.........\$1 $50 \quad \$ 1200$

4 to $5 \mathrm{ft}$., transplanted........... $200 \quad 1800$

Linden, American (Tilia Americana). The Basswood is a native forest tree of unusual, stately beauty. Growth rapid and upright, with smooth branches and broad, heart-shaped leaves; has curiously pendent and creamcolored flowers on long, winged peduncles in July, of delightful fragrance. Few trees equal this, with its rich green foliage and splendid habits of growth, adapting itself readily to various soils and conditions, making it useful for the lawn or street. Each $10 \quad 100$

\begin{tabular}{|c|c|c|c|}
\hline 6 to $8 \mathrm{ft}$. , transplanted..$\$ 1$ & 100 & $\$ 800$ & $\$ 6000$ \\
\hline 8 to $10 \mathrm{ft} .$, transplanted. . 1 & 150 & 1200 & 9000 \\
\hline $\begin{array}{l}10 \text { to } 12 \mathrm{ft} ., 11 / 2 \text { to } 13 / 4 \text { in. } \\
\text { diam., transplanted } \ldots \ldots 2\end{array}$ & 200 & 1800 & 12500 \\
\hline $\begin{array}{l}10 \text { to } 12 \mathrm{ft} ., 2 \text { to } 21 / 2, \mathrm{~m} \text {. } \\
\text { diam., transplanted } \ldots \because .3 \\
10 \text { to } 12 \mathrm{ft} ., 21 / 2 \text { to } 3 \mathrm{in} \text {. }\end{array}$ & 00 & 2500 & 20000 \\
\hline diam., transplanted .... 5 & & 45 & \\
\hline 10 to $12 \mathrm{ft} ., 3$ in. diam., tr.. 7 & 50 & 6000 & \\
\hline 10 to $12 \mathrm{ft} ., 4$ in. diam., $\operatorname{tr} . .10$ & 00 & 9000 & \\
\hline imen trees ... .\$10 to 40 & & & \\
\hline
\end{tabular}

Linden, European (Tilia Europæa). Famous the world over, as an avenue tree of great beauty and dignity. It closely resembles its American cousin, with smaller foliage and de-

\section{Linden, European, continued}

cidedly more compact growth. The pyramidal heads of unusual regularity make it a desirable lawn tree. It grows rapidly, attaining a height of 60 to 80 feet. Foliage is heart-shaped; a deep, rich green, turning to a beautiful yellow and brown in autumn.

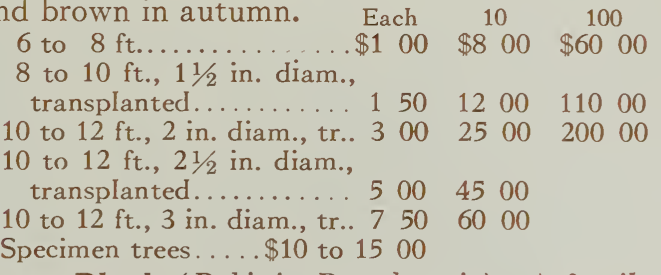

Locust, Black (Robinia Pseudacacia). A familiar tree of rapid growth, that thrives in any place. The pinnate foliage is light and airy. In June the tree is fragrant with panicles of white flowers, and very ornamental. Valuable for planting where quick results are desired.

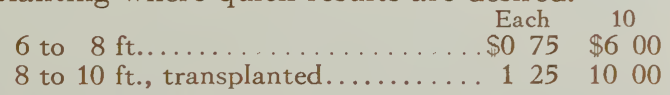

Maple, Ash-leaved (Acer Negundo). Grows rapidly into a Iarge, spreading tree, 70 feet high, found valuable for planting timber claims, shelter-belts, etc., in the West, where it endures both drought and cold. Each $10 \quad 100$

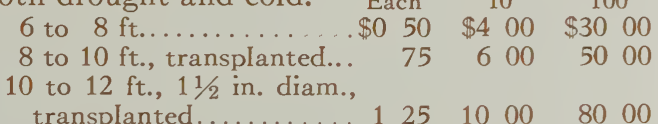
10 to $12 \mathrm{ft} ., 2$ in. diam., tr.. 2001800 10 to $12 \mathrm{ft}$., $3 \mathrm{in.} \mathrm{diam.,} \mathrm{tr..} 4003500$ 12 to $14 \mathrm{ft} ., 4$ in. diam., tr.. 6005500 


\section{ORNAMENTAL TREES, continued}

Maple, Geneva (Acer platanoides, var. Geneva). An exceedingly handsome, crimson-leaved variety of the Norway Maple. The growth is vigorous, and the head rounded and well supported. The leaves are the largest of the Maples, retaining their brilliant crimson-purple coloring all summer, blazing forth in autumn with wonderful shades of red, purple, and gold. Each 10

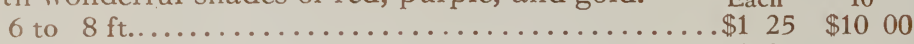

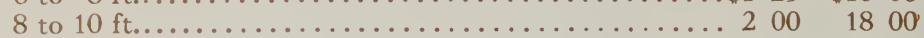

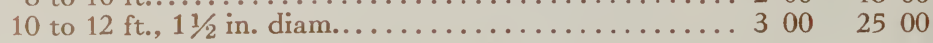

Maple, Norway (Acer platanoides). The compact, vigorous nature of this European tree renders it desirable for the street or lawn. The growth is fairly fast, the head massive and rounded, with rich green foliage of broad, palmately lobed leaves that change to a light yellow in the autumn. A magnificent tree for the avenue.

Each 10

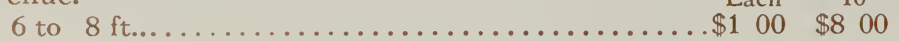

8 to $10 \mathrm{ft}$., transplanted..................... $150 \quad 12 \quad 50 \quad 11000$

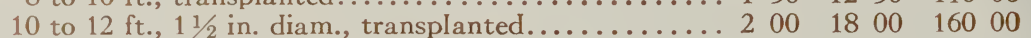

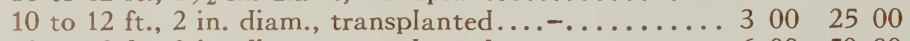

10 to $12 \mathrm{ft} ., 3$ in. diam., transplanted.................. $600 \quad 5000$

Specimen trees.................\$10 to 2000

Maple, Schwedler's (Acer platanoides Schwedleri). The Purple Norway Maple's beautiful leaves attract attention at all seasons, but are especially fine in spring, when their gleaming red and purple contrast brightly with the delicate green of other trees.

5 to $6 \mathrm{ft}$., transplanted.

Each

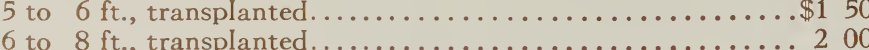

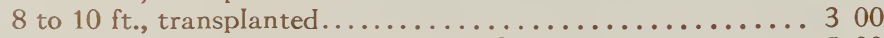

10 to $12 \mathrm{ft} ., 11 / 2$ in. diam., transplanted................ 500

10 to $12 \mathrm{ft} ., 2$ in. diam., transplanted.................. 750

Specimen trees................................ 2500

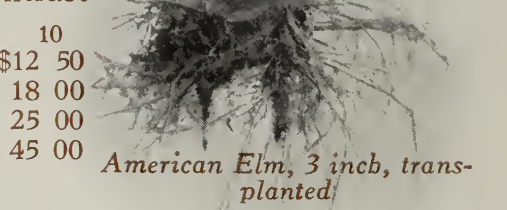

Maple, Silver (Acer dasycarpum). One of the most popular of American Maples, because of its rapid growth, large size and attractively rounded head, with a tendency to graceful arching when care-

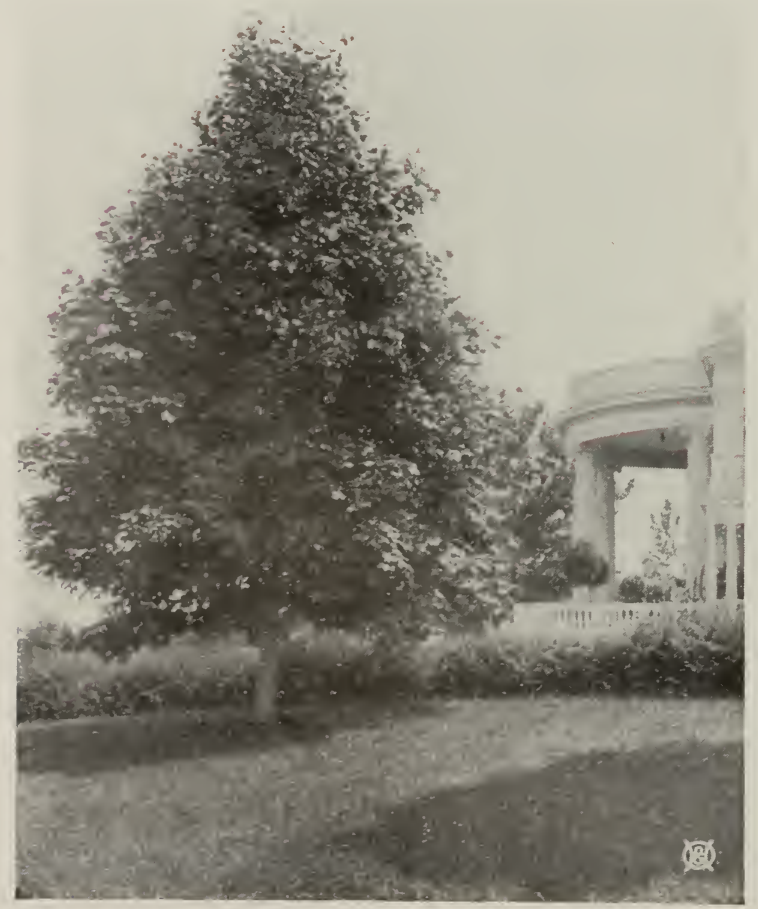

Scbwedler's Norway Maple, about 20 years old. Tbis variety is more erect in growtb than the old Norway Maple fully pruned. For immediate effects, indispensable. Foliage is luxuriant, bright green with silvery white beneath. A favorite for any place.

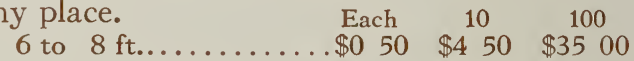

8 to $10 \mathrm{ft}$., transplanted. $100 \quad 800 \quad 7000$ 10 to $12 \mathrm{ft} ., 11 / 2$ in. diam.,tr. $150 \quad 120011000$ 10 to $12 \mathrm{ft} ., 2$ in. diam.,tr. 200180016000 10 to $12 \mathrm{ft} ., 21 / 2$ in. diam., transplanted.........3 $300 \quad 2500$ 12 to $14 \mathrm{ft} ., 3$ in. diam., tr. 5004500 12 to $14 \mathrm{ft} ., 4$ in. diam., tr. 10009000 14 to $16 \mathrm{ft}$., 5 in. diam., tr. 1500 Specimen trees....\$10 to 4000

Maple, Sugar (Acer saccharum). The Rock or Sugar Maple is one of the most symmetrical and well-rounded trees native to America. A straight grower, vigorous, stately, inclined to form a spreading head when given plenty of room. A regal tree for the avenue, a lifelong friend on the home grounds, and a specimen for the parks. Deeply lobed red and green foliage, changing to orange and red tints in autumn. Each $10 \quad 100$

6 to $8 \mathrm{ft} . \ldots \ldots \ldots \ldots . \$ 100 \quad \$ 800 \quad \$ 7000$ 8 to $10 \mathrm{ft}$., transplanted. $150 \quad 12 \quad 00 \quad 11000$ 10 to $12 \mathrm{ft}$., $1 \frac{1}{2}$ in. diam.,

transplanted......... $2 \quad 50 \quad 22 \quad 50$

10 to $12 \mathrm{ft} ., 2$ in. diam., tr. 4003500

Specimen trees.... \$5 to 1500 


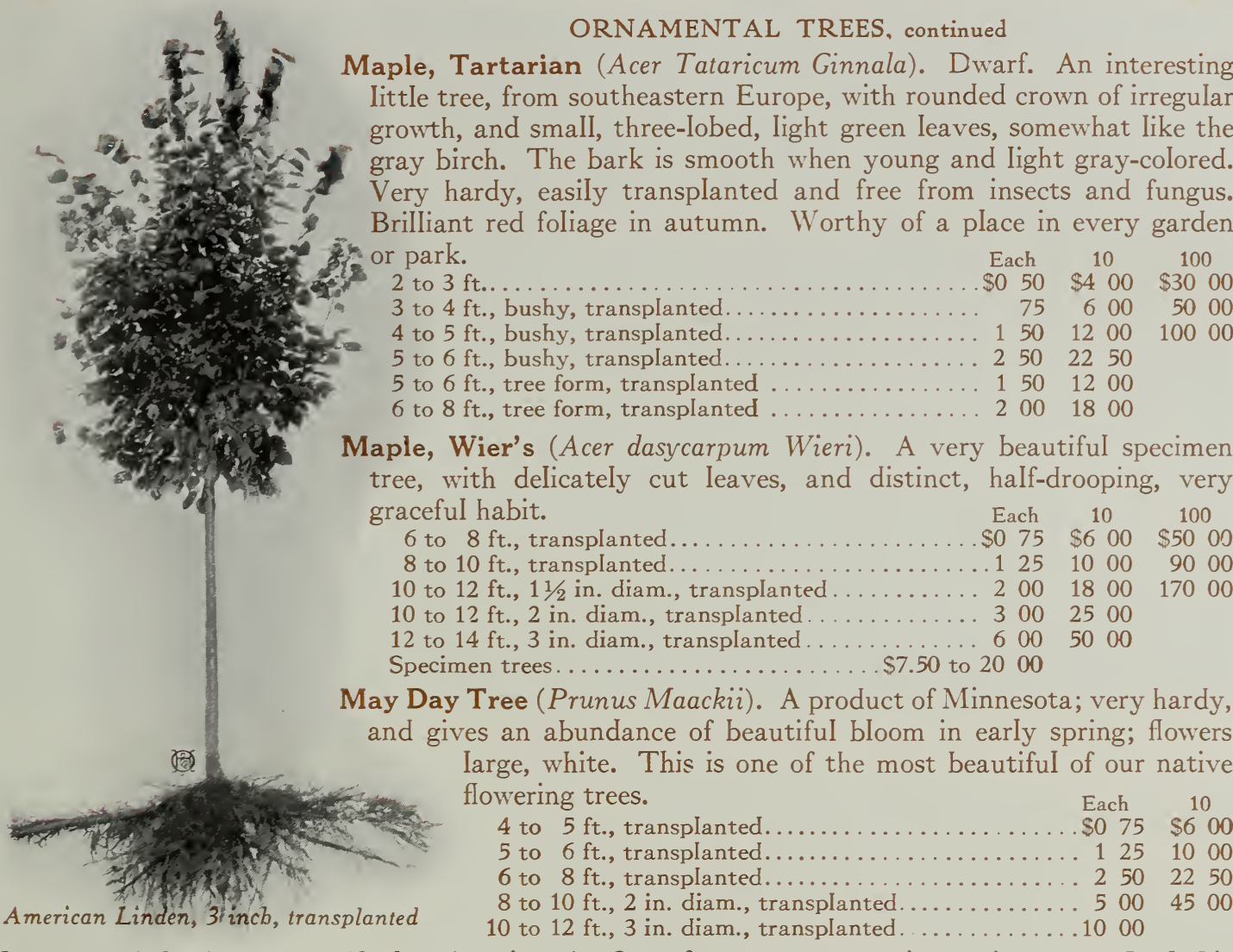

Mountain Ash, American (Sorbus Americana). One of our most attractive native trees. Its habit is much the same as the European variety but is much hardier and the bark is lighter in color. It produces its berries when quite young, which are in large clusters and of orange-color. Especially fine for planting among tall shrubbery, with its brilliant berries.

6 to $8 \mathrm{ft}$., transplanted........ $\$ 100 \quad \$ 800$

8 to $10 \mathrm{ft} ., 11 / 2$ in. diam............. $200 \quad 1800$

10 to $12 \mathrm{ft} ., 2$ to $3 \mathrm{in}$. diam...... 4003500

Specimen trees .........\$5 to 1000

Mountain Ash, European (Sorbus Aucuparia). Very beautifuI, with straight, smooth trunk. Foliage deep green, turning yellow in autumn. Erect growth, 20 to 30 feet high. White flowers in May, followed by bright orange-red berries which cling all winter. Very interesting for lawn or park. Each $\quad 10 \quad 100$

6 to $8 \mathrm{ft}$., transplanted. $\$ 100 \quad \$ 800 \quad \$ 6000$

8 to $10 \mathrm{ft}$., transplanted.. $125 \quad 1200 \quad 8000$

10 to $12 \mathrm{ft}$., $1 \frac{1}{2}$ to $2 \mathrm{in}$.

diam., transplanted.... $200 \quad 1800 \quad 15000$

10 to $12 \mathrm{ft}$., 2 in. diam., tr. 3002500

10 to $12 \mathrm{ft}$., $2 \frac{1}{2}$ to 2 in.

diam., transplanted.... $400 \quad 3500$

12 to $14 \mathrm{ft} ., 3$ in. diam., tr. 6005500

Specimen trees. $\$ 7.50$ to 1500

Mountain Ash, Golden (Sorbus aurea). A golden-leaved variety; dwarf in growth. An excellent tree for constant color in grouping.

5 to $6 \mathrm{ft}$., transplanted....... Each 00

6 to $8 \mathrm{ft}$., transplanted......... 150

8 to $10 \mathrm{ft}$., 2 in. diam., trans. . 300

Specimen trees.........\$5 to 1500

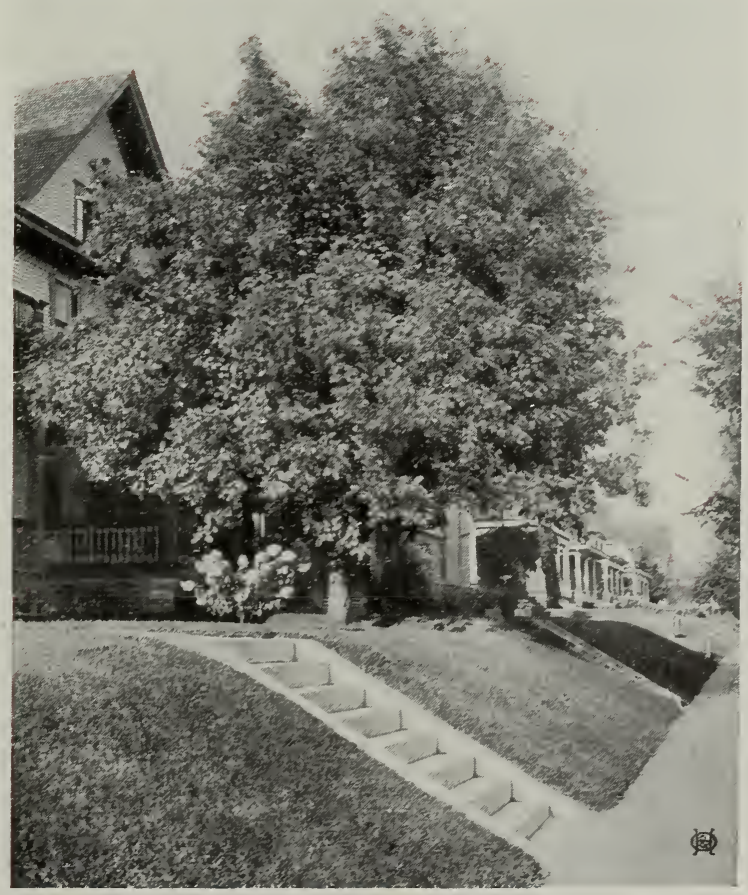

An American Mountain Asb on one of St. Paul's streets 


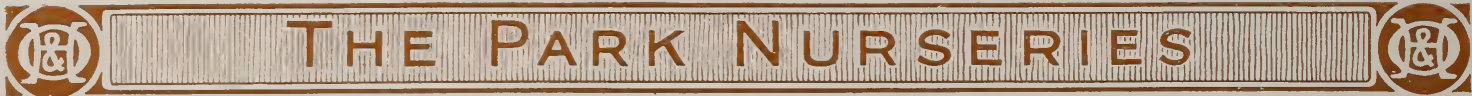

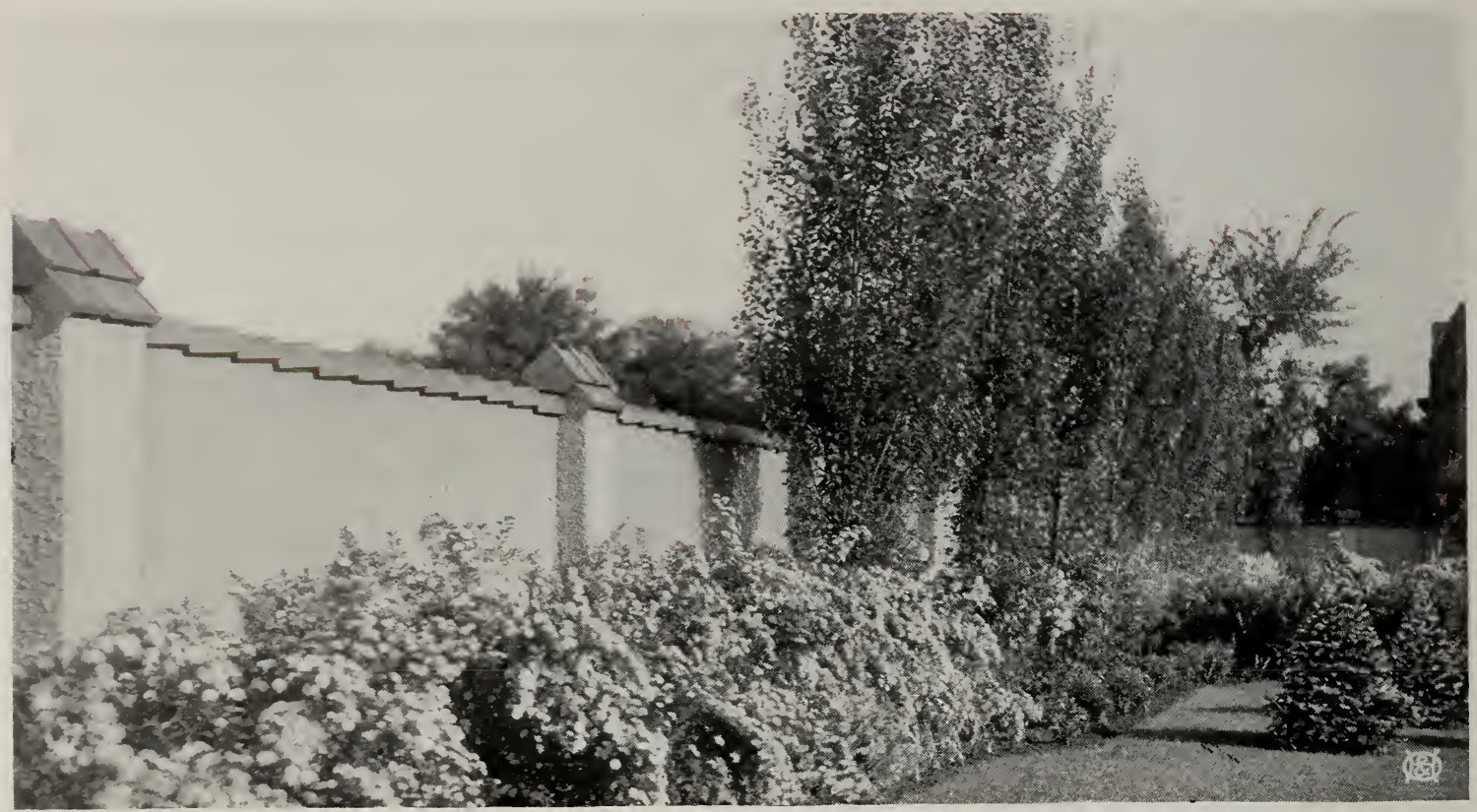

Sbowing a practical use of Lombardy Poplars to screen unsigbtly objects

ORNAMENTAL TREES, continued

Mountain Ash, Oak-leaved (Sorbus quercifolia). Of the same fine habit, but with dark, Iobed leaves, downy underneath.

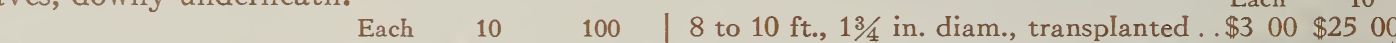

6 to $8 \mathrm{ft}$., transplanted...\$1 $00 \quad \$ 800 \quad \$ 7000 \quad 8$ to $10 \mathrm{ft}$., 2 in. diam., transplanted . . $500 \quad 4500$

8 to $10 \mathrm{ft}$., transplanted ... $150 \quad 1200 \quad 11000 \quad$ Specimen trees.............\$5 to 1000

Mulberry, Russian (Morus Tatarica), A very rapid-growing tree; bears well; fruit sweet, variable in size and color; leaves dark green and of very different shapes; some. are birch-shaped, others cut and notched as much as any of our oaks, and in as many different shapes as all the varieties put together. Will stand almost any amount of drought.

4 to $5 \mathrm{ft}$., transplanted, bushy

5 to $6 \mathrm{ft}$., transplanted, bushy

6 to $8 \mathrm{ft}$., transplanted, bushy

Specimen trees.

$\$ 3$ to 600

\begin{tabular}{rrrr} 
Each & \multicolumn{1}{c}{10} \\
$\$ 0$ & 50 & $\$ 4$ & 00 \\
& 75 & 6 & 00 \\
1 & 25 & 10 & 00
\end{tabular}

Oak, Pin (Quercus palustris). We consider this and Coccinea the best two Oaks. It is distinguished by its elegant growth and the drooping tendency of its limbs, and fine, deeply cut foliage, which, in the faII, colors brilliantly. Being one of the easiest Oaks to transplant, it is in great favor as a street tree. Each 10
4 to $5 \mathrm{ft}$.
$\$ 100 \quad \$ 800$
5 to $6 \mathrm{ft}$
8 to $10 \mathrm{ft} ., 1 \frac{1}{2}$ in. diam., transplanted
$\begin{array}{llll}125 & 10 & 00\end{array}$
Specimen trees
$\$ 5$ to 1000

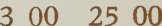

Oak, Scarlet (Quercus coccinea). There is no better Oak than this variety. It forms a large tree of fine proportions, the large, leathery leaves turning to a fiery scarlet in autumn. A good street tree. 4 to $5 \mathrm{ft}$....

5 to $6 \mathrm{ft}$.

8 to $10 \mathrm{ft}, 11 / 2$ in. diam., transplanted.

Each

$\$ 100$

Specimen trees.

$\begin{array}{llll}1 & 25 & 10 & 00\end{array}$

3002500

$\$ 5$ to 1000

Oak, White (Quercus alba). A weIl-known, grand, old native tree, with broad, spreading head. It grows easily in almost any soil, and, contrary to general belief, does not grow slowly. Seldom requires trimming or attention, and will reach a ripe old age.

4 to $5 \mathrm{ft}$., transplanted

Each 10

5 to $6 \mathrm{ft}$., transplanted

$\$ 100 \quad \$ 800$

8 to $10 \mathrm{ft}$., $11 / 2$ in. diam., transplanted.

$\begin{array}{llll}1 & 25 & 10 & 00\end{array}$

Specimen trees.

$300 \quad 2500$

$\$ 5$ to 1000
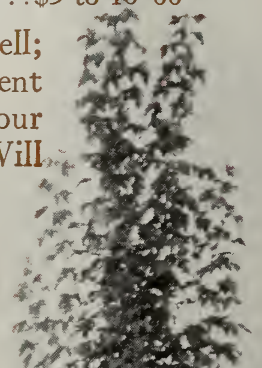


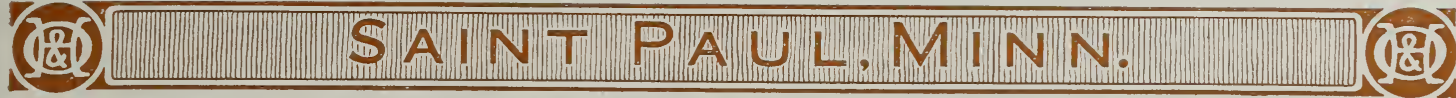

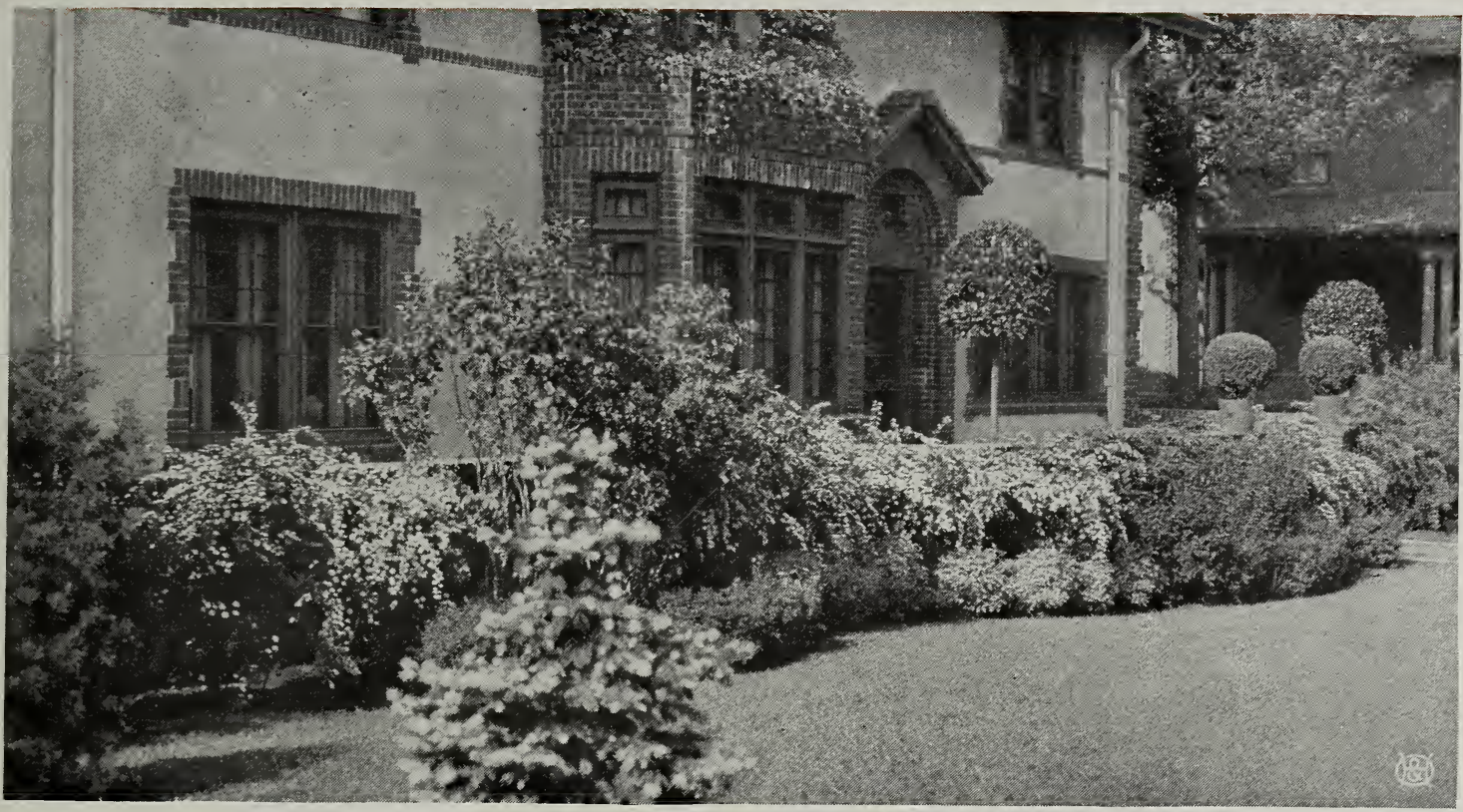

A planting of evergreens and shrubs that is distinct in character. Note the use of Bay Trees and Box

\section{ORNAMENTAL TREES, continued}

Plum, Purple (Prunus Pissardi). Handsome form, with purple Ieaves and wine-red fruits; one of the best of the smaIl purple-leaved trees, retaining its color until fall. Hardy wherever the common Plum will stand.

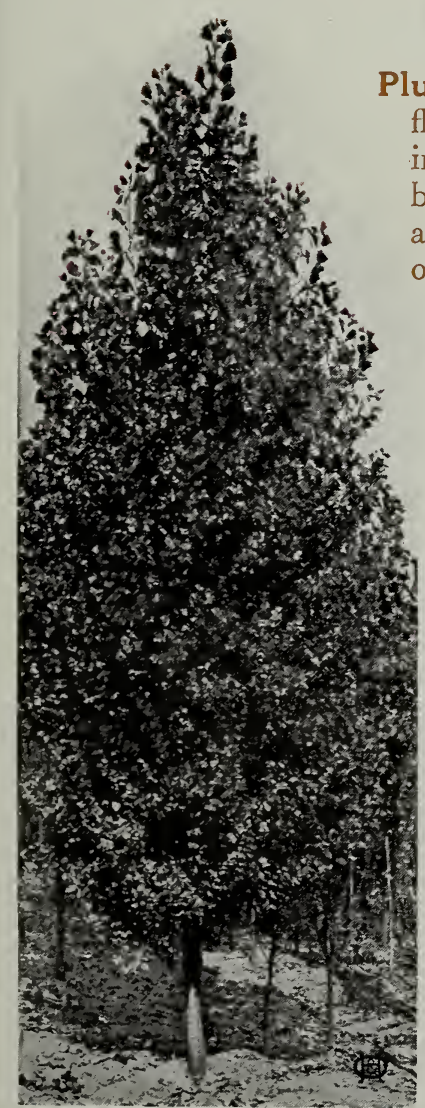

Lombardy Poplar (see page 14)
4 to $5 \mathrm{ft}$. . . .

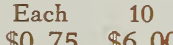

5 to $6 \mathrm{ft}$..

$100 \quad 800$

Plum, Double-flowering (Prunus triloba). A very desirable and beautiful flowering shrub coming from China. It resembles the flowering almond in its blossoms, also in the manner in which it blooms. Early in the spring, before its leaves appear, its beautiful, delicate pink petals begin to unfold and when fully open resembles a miniature rose. Its branches are a mass of blossoms, and bend gracefully with their weight.

2 to $3 \mathrm{ft}$..

3 to $4 \mathrm{ft}$., transplanted

4 to $5 \mathrm{ft}$., transplanted

Specimen trees

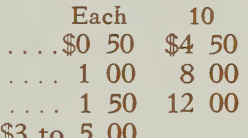

$\$ 3$ to 500

Poplar, Balsam, Balm of Gilead (Populus balsamifera). A handsome native, with thick, dark, ovate leaves, silvery beneath. The flowers come in early spring, in catkin-like form. The spicy gum of the buds is used medicinally.

6 to $8 \mathrm{ft}$. .

8 to $10 \mathrm{ft}$., transplanted

10 to $12 \mathrm{ft}$., $11 / 2 \mathrm{in}$. diam., transplanted

10 to $12 \mathrm{ft} ., 2 \mathrm{in}$ diam., transplanted.

10 to $12 \mathrm{ft}$., $2 \frac{1}{2} \mathrm{in}$. diam., transplanted Specimen trees.

Poplar, Bolleana (Populus alba, var. Bolleana). This splendid upright silver Poplar resembles the Lombardy in growth, but more desirable, as it is longer-lived. A tree of lofty and inspiring habits, suitable for tall screening and architectural emphasis. Should be planted advisedly.

6 to $8 \mathrm{ft}$..

8 to $10 \mathrm{ft}$. , transplanted

10 to $12 \mathrm{ft} ., 11 / 2 \mathrm{in}$. diam., transplanted

10 to $12 \mathrm{ft}$., 2 in. diam., transplanted

12 to $14 \mathrm{ft} ., 21 / 2$ in. diam., transplanted

12 to $14 \mathrm{ft}$., $3 \mathrm{in}$. diam., transplanted.

Specimen trees.

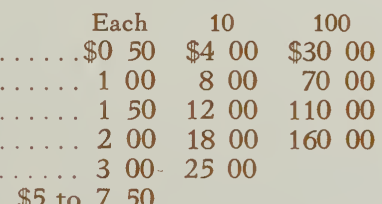

$\begin{array}{lll}\text { Each } & 10 & 100\end{array}$

$\begin{array}{llllll}\$ 1 & 00 & \$ 8 & 00 & \$ 70 & 00\end{array}$

$\begin{array}{llllll}150 & 12 & 00 & 110 & 00\end{array}$

$\begin{array}{llllll}2 & 00 & 18 & 00 & 170 & 00\end{array}$

$\begin{array}{llll}3 & 00 & 2500\end{array}$

$400 \quad 3500$

$600 \quad 5500$

$\$ 10$ to 1500 


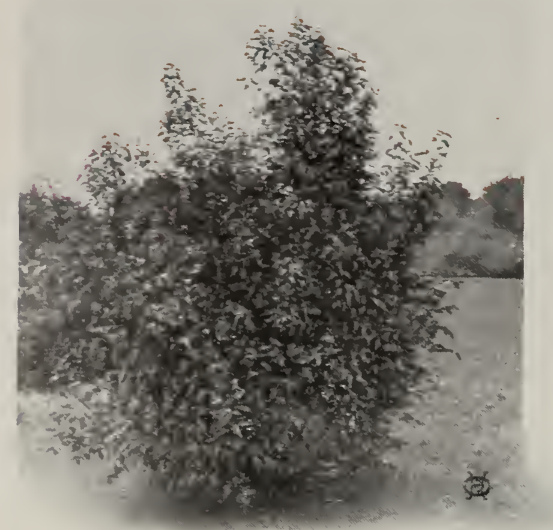

The Tartarian Maple is distinguished by brilliant autumn foliage (see page 11)
ORNAMENTAL TREES, continued

Poplar, Carolina (Populus monilifera). Unexcelled for quick growth and effect, its rapid growth giving an air of Iuxuriance to places where other trees appear starved. Showy and cheery from the constant movement of its glossy, silver-lined leaves, yet always casting a dense, close shade. If weIl pruned back, during the frrst few seasons, it makes a strong, durable tree.

$\begin{array}{lll}\text { Each } & 10 & 100\end{array}$

6 to $8 \mathrm{ft}$., transplanted............. \$0 $50 \quad \$ 400 \quad \$ 2500$

8 to $10 \mathrm{ft}$., transplanted............ $75 \quad 600 \quad 5000$

10 to $12 \mathrm{ft} ., 11 / 2$ in. diam., transplanted... $100 \quad 800 \quad 7500$

10 to $12 \mathrm{ft}$., 2 in. diam, transplanted...... $150 \quad 1200 \quad 11000$

10 to $12 \mathrm{ft} ., 21 / 2 \mathrm{in}$. diam, transplanted... 2502200

12 to $14 \mathrm{ft} ., 3 \mathrm{in}$. diam., transplanted.... $400 \quad 3500$

12 to $14 \mathrm{ft} ., 4 \mathrm{in.} \mathrm{diam.,} \mathrm{transplanted....} 600 \quad 5000$

Specimen trees..............\$6 to 1000

Poplar, Lombardy (Populus fastigiata). Few trees add so much to a landscape as this European importation. Adapts itself rapidly to aII conditions and soils. Leaves serrated, deep glossy green and nearly triangular, tremulously nodding with the wind, and borne on erect, long, slender branches. The erect, vigorous and fuII spiry form of 100 to 150 feet lends a charm and dignity to a street, boundary or landscape, which is inspiring and refreshing, after turning from the monotonous and unbroken

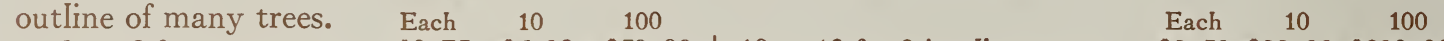
6 to $8 \mathrm{ft} . \ldots \ldots \ldots \ldots \ldots \ldots \$ 75 \$ 600 \$ 5000 \mid 10$ to $12 \mathrm{ft} ., 2 \mathrm{in.}$ diam., trans...\$2 $50 \$ 2200 \$ 200 \quad 00$

8 to $10 \mathrm{ft}$., transplanted. $100 \quad 800 \quad 7000 \quad 12$ to $14 \mathrm{ft}$., $2 \frac{1}{2} / 2$ in. diam., trans. $350 \quad 3000$

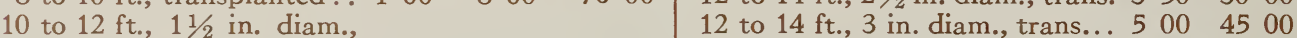

transplanted .......... $150 \quad 1200 \quad 11000$ Specimen trees.......\$5 to 1000

Poplar, Norway (Populus certinensis). This true Russian or Siberian Poplar deserves wider planting. With all the best characteristics of the Carolina Poplar, it is hardier and far more picturesque. The tree has a strong central trunk, and heavy, dense foliage. Growth is close and erect. The leaves are distinguished by crinkled edges, presenting a very curious appearance.

Each $\quad 10 \quad 100$

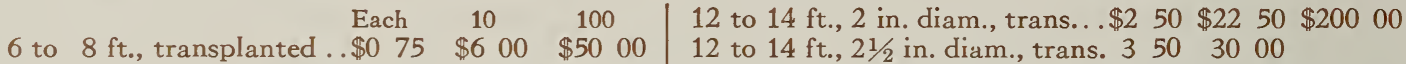

8 to $10 \mathrm{ft}$ transplanted. 12 to $14 \mathrm{ft}$., $21 / 2$ in. diam., trans. 3503000

12 to $14 \mathrm{ft} ., 3$ in. diam., trans... 5004500

10 to $12 \mathrm{ft}$., $11 \frac{1}{2}$ in. diam., tr. $1501200 \quad 11000$ Specimen trees.......... \$5 to 1000

Poplar, Silver (Populus alba). A very rapid grower, inclined to spread; smooth, gray bark, Ieaves deeply Iobed, dark glossy green on upper side and snowy. white beneath. The contrast of white against the green is pleasing and attractive. Desirable for color effects on large estates or parks only, as inclined to sprout where unattended. Each 10

6 to $8 \mathrm{ft}$., transplanted......\$0 $75 \$ 600$

8 to $10 \mathrm{ft}$., transplanted....... $100 \quad 800$

8 to $10 \mathrm{ft}$., $1 \frac{1}{2}$ in. diam., tr... 1501200

8 to $10 \mathrm{ft}$., $2 \mathrm{in.} \mathrm{diam.,} \mathrm{trans..} 3002500$

Specimen trees......\$5 to 750

Sumac, Smooth (Rhus glabra). Excellent foliage. The flowers are borne in panicles at the ends of the branches, and are followed in autumn with prominent crimson heads of seed which remain nearly all winter. This Sumac is desirable for massing; the brilliant coloring of the foliage in autumn is especially attractive.

4 to $5 \mathrm{ft}$.

Each 10

$\begin{array}{llll}\$ 0 & 50 & \$ 400\end{array}$

5 to $6 \mathrm{ft}$., transplanted...... $75 \quad 600$

6 to $8 \mathrm{ft}$., transplanted ........ $100 \quad 800$

Specimen trees .......\$3 to 500

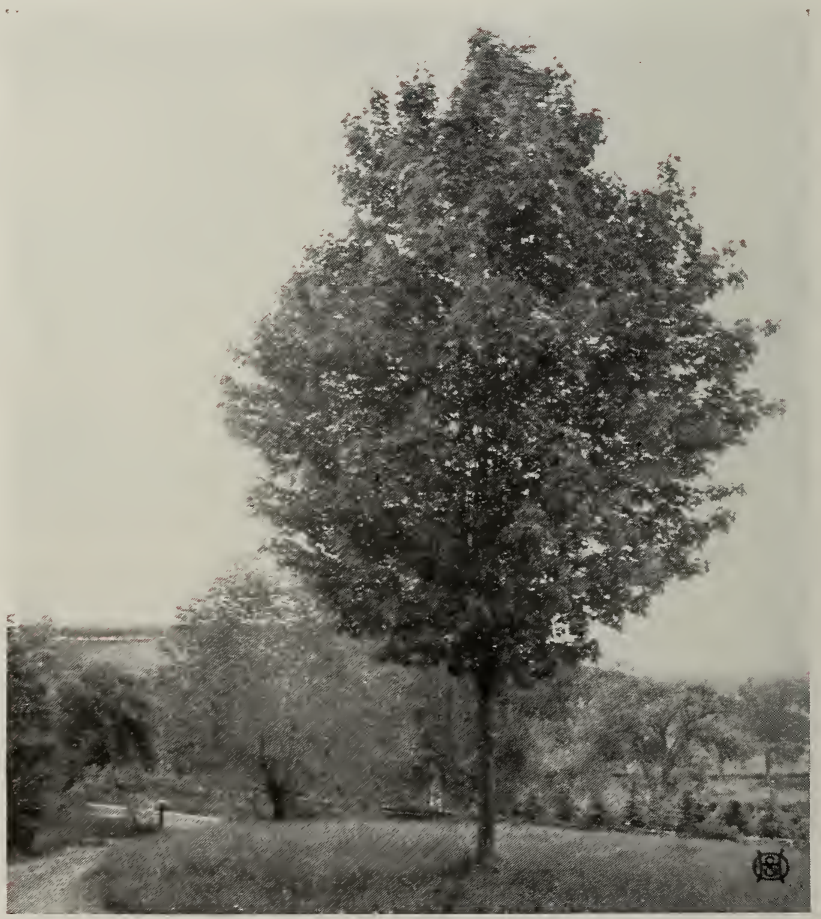

The Sugar Maple becomes a life-long friend (see page 10) 
ORNAMENTAL TREES, continued

Sumac, Cut-leaved (Rbus typhina). Grows generally in bush form to 10 feet in height; the foliage is compound, light green and of large size; in autumn is brilliantly colored. A most effective plant for grouping in masses; thrives on poor soil.

3 to $4 \mathrm{ft}$., transplanted.

Each 10

.................. \$0 $50 \$ 400$

4 to $5 \mathrm{ft}$., transplanted.................... $75 \quad 600$

Specimen trees .................. $\$ 3$ to 500

Walnut, Black (Juglans nigra). No grander tree in America. Lofty height and shapely crown, with beautiful compound foliage consisting of thirteen to seventeen leaflets. Trunk well rounded. Bark dark and deeply ridged. Becoming rare because of value of its wood. Bears large, edible nuts. Conspicuously ornate and useful for lawn or park planting. Requires deep soil to attain best growth. Each $10 \quad 100$ 5 to $6 \mathrm{ft} . \ldots \ldots \ldots \ldots \ldots \ldots \ldots \ldots \ldots$.............. $50 \$ 400 \$ \$ 3000$ 6 to $8 \mathrm{ft}$, transplanted............. $100 \quad 800 \quad 7000$ 8 to $10 \mathrm{ft}$., transplanted............. $150 \quad 1200$

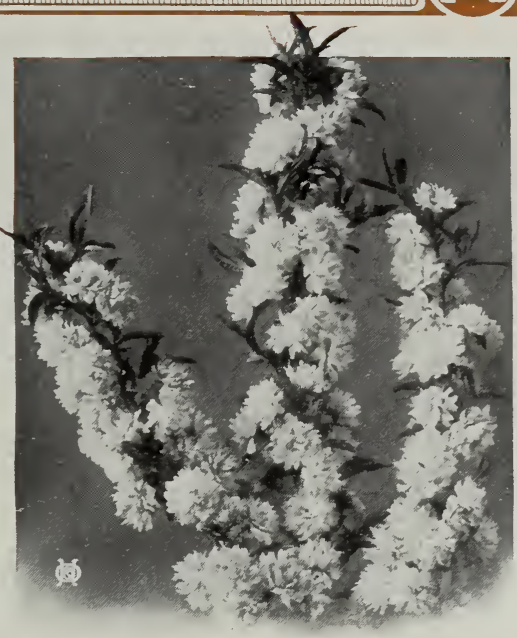

Graceful flower-laden brancbes of the Double-flowering Plum (see page 13)

Willow, Golden (Salix vitellina aurea). For winter effects, the Golden Willow is invaluable. A rapid grower, with branches of rich golden bark. The younger growth produces the brightest wood, hence should be severely pruned. Handsomely contrasts with red osier, etc. Useful for screen plantings on estates or parks.

\begin{tabular}{cccc|cccccc} 
Each & 10 & 100 & 10 to $12 \mathrm{ft} ., 11 / 2 \mathrm{in}$. diam., trans. $\$ 150$ & $\$ 1200$ & $\$ 110$ & 00
\end{tabular}

8 to $10 \mathrm{ft}$., transplanted... $100 \quad 800 \quad 7000$ Specimen trees..........\$4 to 800

Willow, Laurel (Salix pentandra). Grown in tree and bush forms. Highly ornamented with light brown branches and foliage of deep, glossy green, ovate leaves. Useful for screening and for foliage color effects. Grows rapidly in any soil and especially in sandy situations. Stands harsh pruning for bush effects. A most desirable Willow.

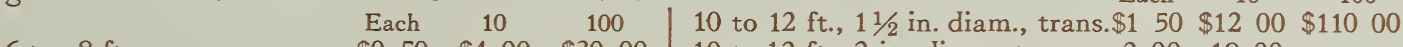
6 to $8 \mathrm{ft} . \ldots \ldots \ldots \ldots \ldots \$ 0 \quad 50 \quad \$ 400 \$ 3000 \quad 10$ to $12 \mathrm{ft} ., 2 \mathrm{in}$. diam., trans.. $200 \quad 1800$

8 to $10 \mathrm{ft}$., transplanted... $100 \quad 800 \quad 7000$ Specimen trees.........\$4 to 800

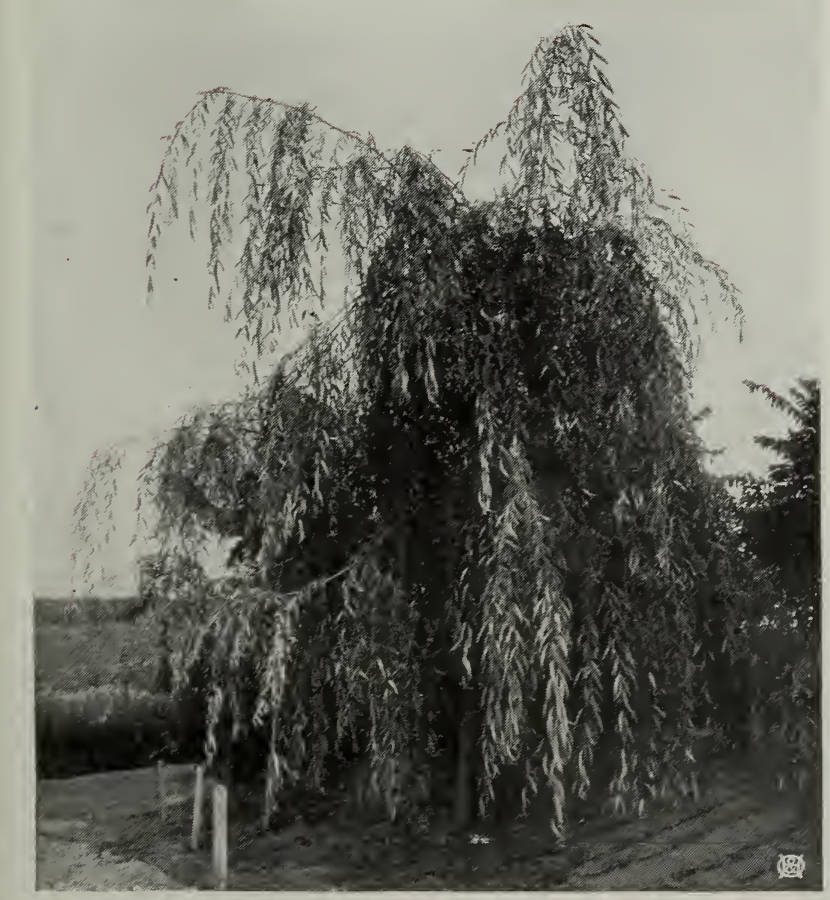

Niobe Willow growing in The Park Nurseries. Sucb trees transplant readily

Willow, Niobe (Salix Niobe). A golden barked Willow of decided weeping habit, yet not a headed tree, as its branches weep from its own stem. This is quite an acquisition to the Northwest, as all the weeping varieties are tender. Professor Hansen, of the South Dakota Experimental Station, found this variety in Northern Europe and gave it its name. The tree is a good grower, has long, pendulous branches that almost reach the ground; in winter the wood is a bright yellow, making a very effective contrast in working out color schemes. $\quad$ Each $10 \quad 100$

6 to $8 \mathrm{ft}$., trans...... \$1 $00 \quad \$ 800 \quad \$ 7000$ 8 to $10 \mathrm{ft}$., trans.... $150 \quad 1200 \quad 11000$ 10 to $12 \mathrm{ft}$., trans.. $250 \quad 2000$ Specimen trees, $\$ 5$ to $\$ 25$ each.

We have some beautiful specimens, almost 10 feet across, with branches touching the ground.

We pay especial attention to having our trees all correct as to name, and they are planted in the nursery rows sufficiently far apart for them to develop into first-class specimens. This is an important feature in growing trees. 


\section{(1900) THE PARK NURSERIES (1906)}

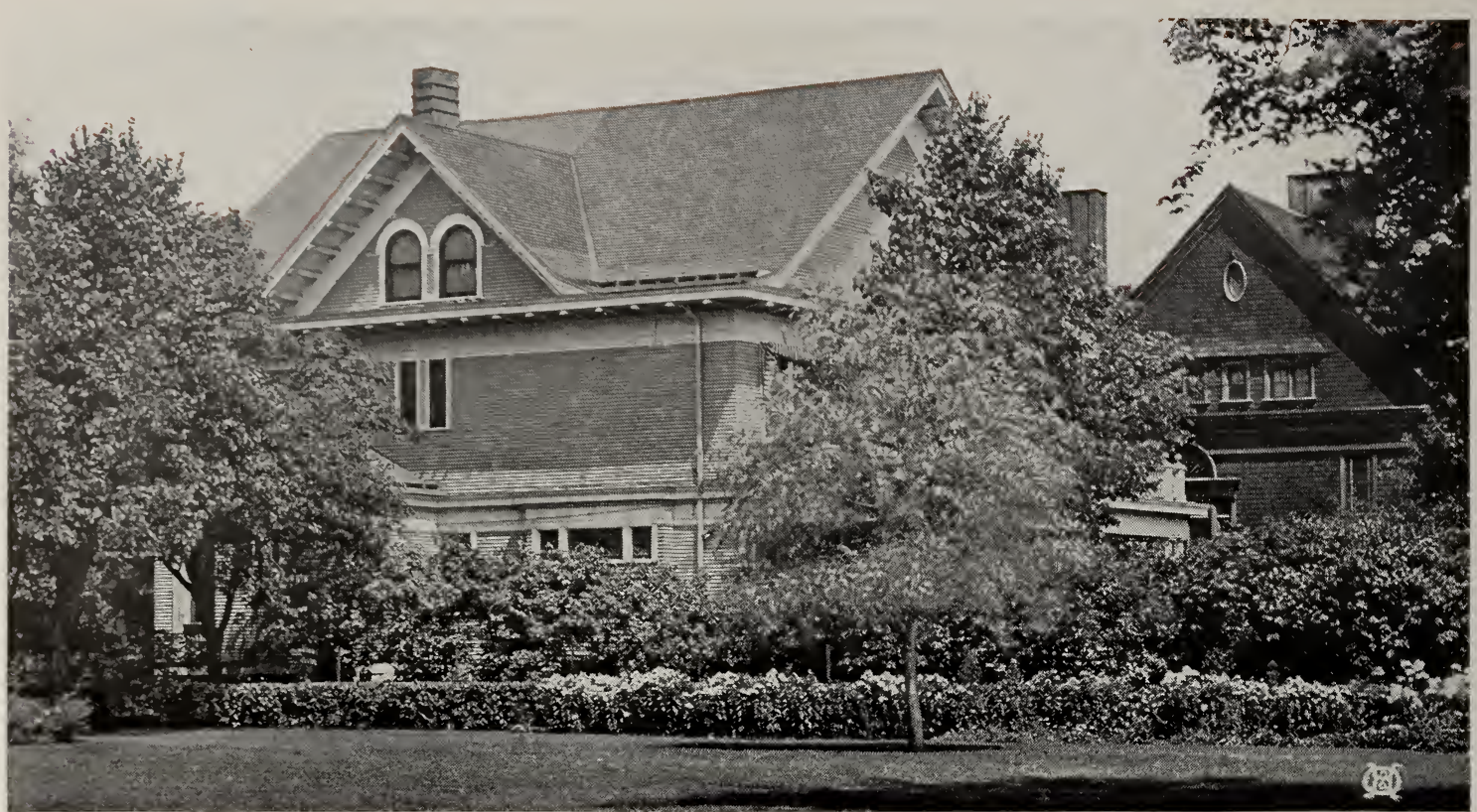

Niobe weeping willow is a beautiful lawn tree. This specimen, 5 inches in diameter, was planted in Spring, 1916

\section{WEEPING TREES}

7 REES of this class are not mournful, as the expression would seem to imply, but the tendency of their growth is drooping. Trees of their habit are great acquisitions to the ornamentals. Certain characteristics about them are very striking and make them attractive; they are interesting from their oddity, and indispensable for landscape effects.

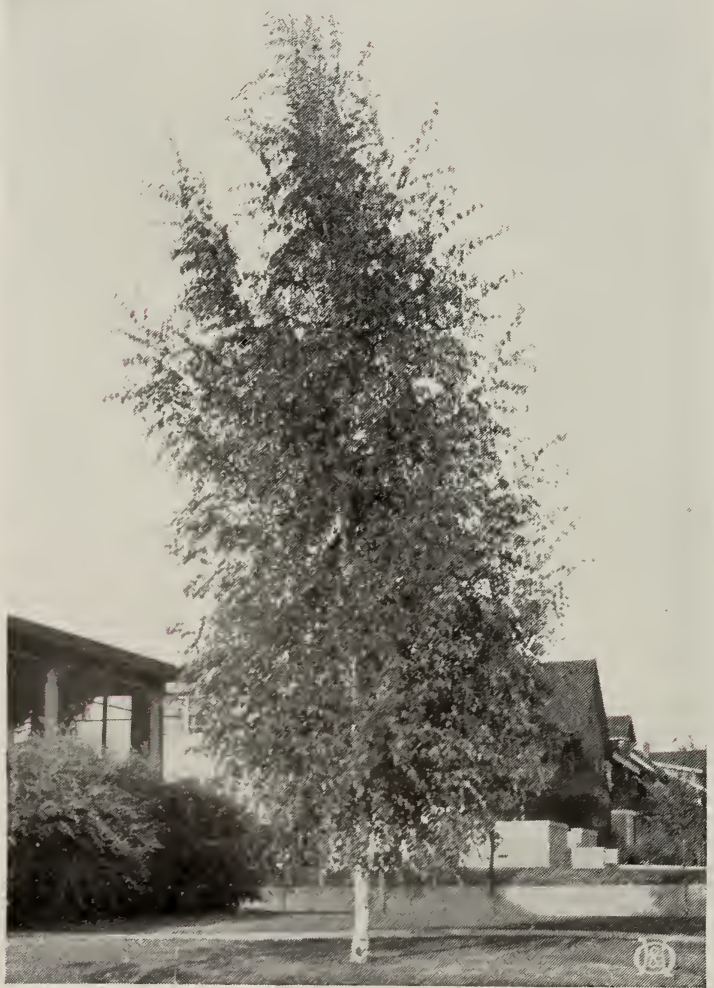

Cut-leaved Weeping Birch

Birch, Cut-leaved Weeping (Betula laciniata pendula). One of the most beautifuI and desirable trees for the lawn, with delicately cut foliage. The bark is silvery white, forming a beautiful contrast with the foliage. It makes a rapid growth, and is perfectly hardy everywhere. Mr. Scott, in his "Suburban Home Grounds," says of it: "No engraving can do it justice; like the palm trees of the tropics, it must be seen in motion-swaying in the lightest breeze, its white bark glistening through the bright foliage and sparkling in the sunto enable us to form a true impression of its character." Each $10 \quad 100$

5 to $6 \mathrm{ft} . \ldots \ldots \ldots \ldots \ldots . \$ 100 \quad \$ 800 \quad \$ 7000$

6 to $7 \mathrm{ft} . \ldots \ldots \ldots \ldots \ldots \ldots \ldots \ldots$

7 to $8 \mathrm{ft} . \ldots \ldots \ldots . \ldots 2001800 \quad 17000$

7 to $8 \mathrm{ft}$., transplanted.... $2 \quad 50 \quad 2200$

8 to $10 \mathrm{ft}$., transplanted ... $300 \quad 2500$

8 to $10 \mathrm{ft} ., 1 \frac{1}{2}$ in. diam., tr. 5004500

Specimen trees.... $\$ 10$ to 2500

Elm, Camperdown (Ulmus pendula). A remarkably picturesque weeping tree, that cxtends its branches horizontally until it forms a complete arbor. It does not grow over 15 feet high, while its branching head often

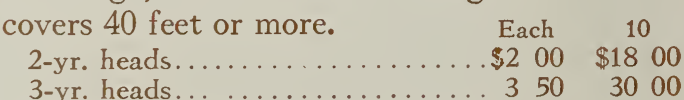

Specimen trees. budded, 10 and $12 \mathrm{ft} \ldots \ldots \ldots \ldots \ldots \ldots \$ 10$ to 2000 


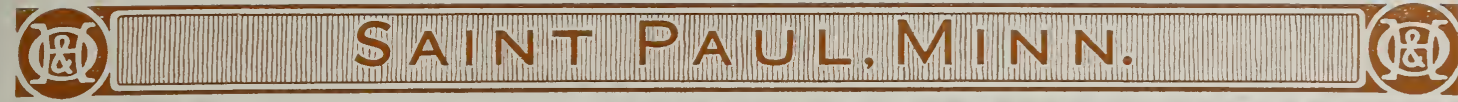

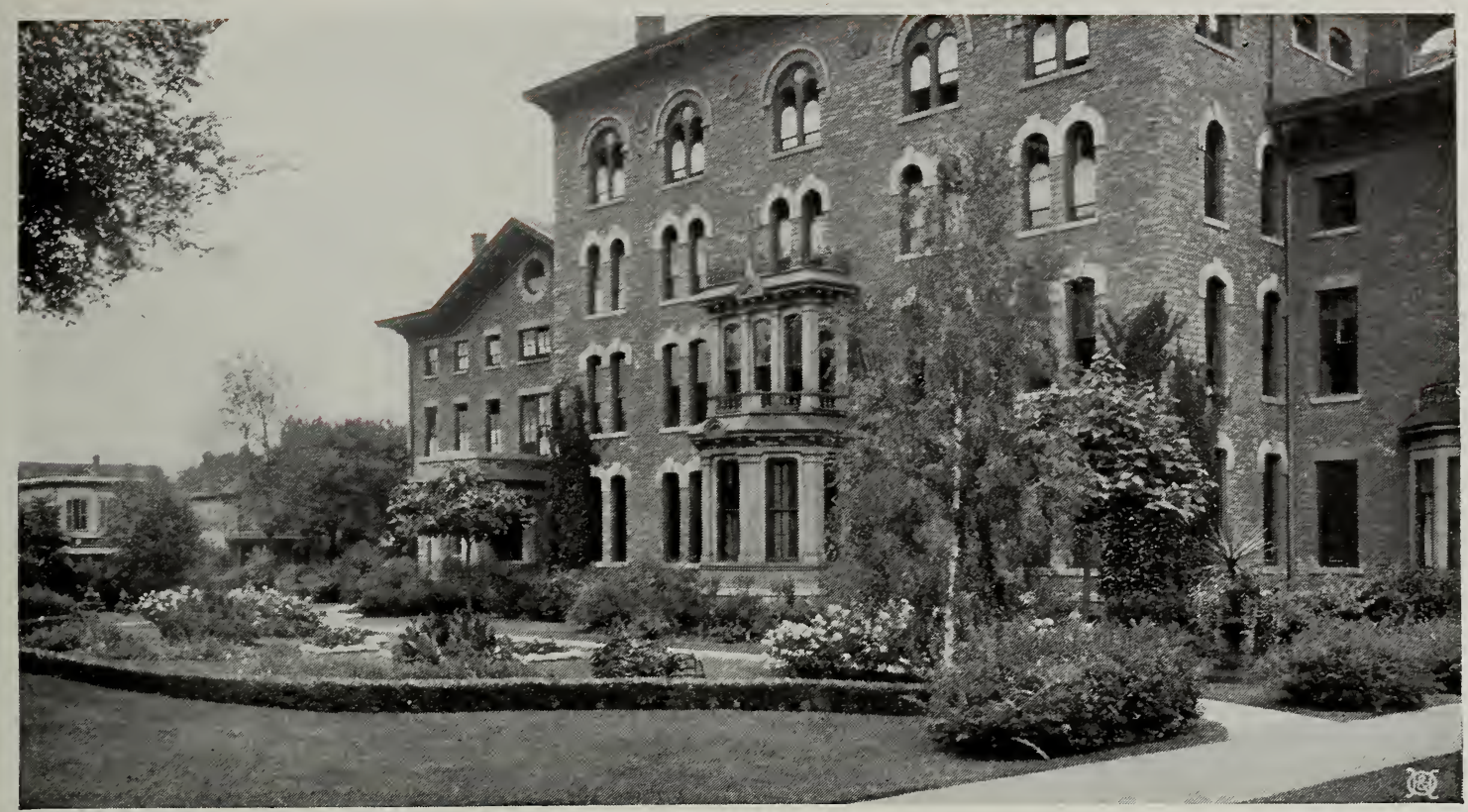

The grounds about the St. Joseph Academy were treated by the H. \& O. landscape service

WEEPING TREES, continued

Maple, Wier's Cut-leaved Weeping (Acer dasycarpum Wierii). One of the most rapid- and graceful-growing of weeping trees, forming beautiful specimens in a short time. Its foliage is deeply cut, and is borne upon long, recurving, pendulous branches. Can be pruned severely. Each 10

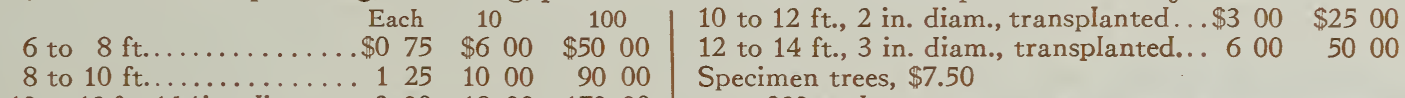

10 to $12 \mathrm{ft}$., $1 \frac{1}{2}$ in., diam., tr. $200180017000 \quad \begin{array}{r}\text { to } \$ 20 \text { each. } \\ \text { to }\end{array}$

Mountain Ash, Weeping (Sorbus Aucuparia pendula). The pendent character, turning and twisting in every direction, each branch apparently struggling to be as different from its neighbor as possible, producing a pleasing effect. Like the other varieties of the family, the tree bears many clusters of bright red berries, which hang all winter. The pinnate foliage is distinctively beautiful.

2 -yr. heads. .

3-yr. heads, transplanted

Each 10

Specimen trees...........

$\$ 150 \$ 1200$

$300 \quad 2500$

$\$ 5$ to 1000

Mulberry, Teas' Weeping (Morus Tatarica pendula). We cordially recommend this as one of the thriftiest, hardiest and most beautiful of weeping trees. Grafted on a straight stem, 6 to 8 feet high, its branches sweep the ground, forming a beautiful tent of green; it forms a delightful play-house for the children. It transplants easily and is appropriate for both large and small places. The leaves are Iustrous and distinctly lobed, much like the typical Mulberry leaf.

2-yr. heads. .

3-yr. heads. .

$\begin{array}{lc}\text { Each } & 10 \\ \ldots \ldots \$ 200 & \$ 1800 \\ \ldots 5 \text { to } 1000 & 2500\end{array}$

Specimen trees

Willow, New American Weeping (Salix Americana pendula). Dwarfer than the Kilmarnock Willow, and much more gracefuI and satisfactory as a lawn tree. The long, drooping branches fairly sweep the ground and make a veritable canopy of rich green foliage. This is one of the most graceful of the weeping trees, and is particularly fine for small places.

Each 10 2-yr. heads. .

.$\$ 150 \$ 1200$

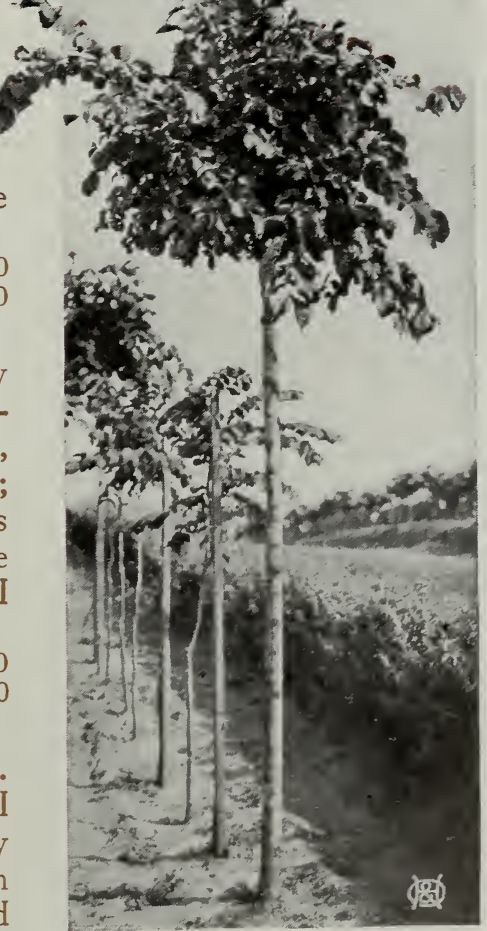

Young Camperdown Elms in Tbe Park Nursery (see page 16) 


\section{EVERGREENS}

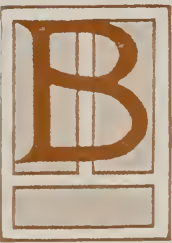

EAUTIFUL groupings can be made by carefully selecting such varieties as go well together; but one must know the habit of growth and be able to contrast the different foliage so that the real beauty will stand out. Only in recent years have we begun to discover new uses for evergreens, and no longer are these trees used only for screens or classed as fit only for cemeteries.

They furnish backgrounds for flowering shrubs; and the winter landscape is not complete without the cheerful colors of the various shades of the evergreens.

Our evergreens are given special care, handled carefully and transplanted frequently, so there is no danger in moving them from our nurseries. Each tree is planted so that it grows symmetrically and develops into a shapely specimen. AII evergreens are priced balled with earth and wrapped in burlap, so that they reach customers in good condition.

Arborvitæ, American (Thuya occidentalis). The well-known screen and hedge plant. Grows naturally to a tree 40 feet tall, but can be kept down to any size by shearing, which it stands without loss of vigor. Will grow even in wet soiIs.

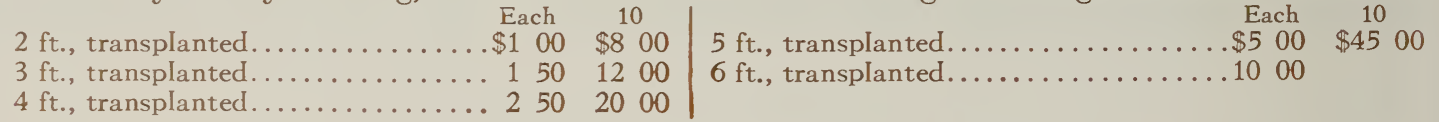

Arborvitæ, Compact (Thuya compacta). Dwarf and compact in its growth. Good for outside border in evergreen groups. It is one of those pleasing types of tree that everybody likes. Each 10
$2 \mathrm{ft}$., transplanted.
Each $10 \quad 21 / 2 \mathrm{ft}$. , transplanted............... \$3 $00 \quad \$ 2500$

Arborvitæ, Douglas Golden (Thuya Douglasii aurea). One of the best golden colors in evergreens. A compact form and very striking in group plantings.
$2 \mathrm{ft}$., transplanted.
$\$ 250$
$\$ 2000$
Each 10
$\$ 500 \$ 4500$

Arborvitæ, Globe (Thuya globosa). Very dwarf and compact; grows naturally into a rounded, almost ball-like form, that makes it useful in groupings for specimens, vases, or for formal planting about garden walks, etc. Each 10

\begin{tabular}{|c|}
\hline 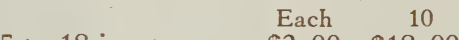 \\
\hline
\end{tabular}

Arborvitæ, Pyramidal (Thuya pyramidalis). Its columnar habit makes it especially valuable for plantings, giving height and uneven lines. No other variety is better suited for formal plantings or working in formal gardens. It is the hardiest of the Arborvitæs, and should be used extensively.

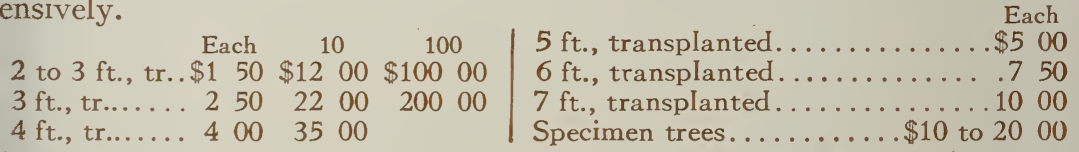

Arborvitæ, Rivers' (Thuya Riversii). Of pyramidal form, broad at the base and upright in growth, having a beautiful green color; adds distinction to groups.

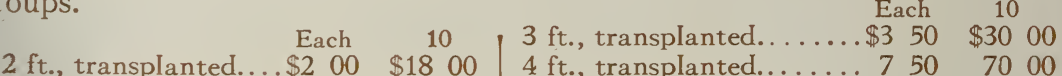

Arborvitæ, Rosenthal's (Thuya pyramidalis Rosenthalii). A new variety of the pyramidal type, darker green, growing more compact; in fact, a beautiful and graceful tree.
$2 \mathrm{ft}$, transplanted....\$3 00
$3 \mathrm{ft}$., transplanted.... 500
$\$ 2500 \mid 4 \mathrm{ft} .$, transplanted.............. $\$ 1000$
Each
\begin{tabular}{r|l}
4500 & Specimen trees...............\$10 to 2000
\end{tabular}

Arborvitæ, Siberian (Thuya Wareana Sibirica). Grows very compact and of pyramidal form, foliage rich dark green and very dense.

Pyramidal Arborvitæ

(Tbuya pyramidalis)

$2 \mathrm{ft}$., transplanted....\$2 50

$\$ 2000$

$\$ 350$

10 
EVERGREENS, continued

Arborvitæ, Siberian (Thuya Sibirica). Of low, compact growth, much like a dwarf. The branches are heavier, and its dark, rich green foliage, which is very dense, makes it most desirable.

18 in., transplanted......... Each $\quad 25 \quad \$ 1000$

$2 \mathrm{ft}$, transplanted.............2 $200 \quad 1800$

Fir, Balsam (Abies balsamea). A regular, symmetrical tree, assuming the cone shape when quite young. Leaves dark, lighter beneath.

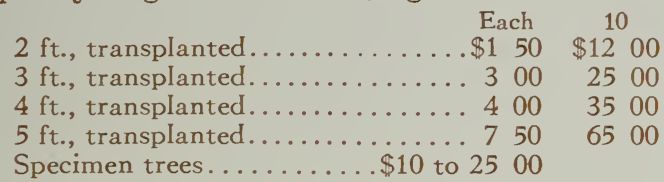

Fir, Double Balsam (Abies Fraseri). This variety is much more desirable than Balsam Fir. Its foliage is double and its silvery line in the sun is very attractive. Its dark green color with its silvery lining and symmetrical form make it attractive in the landscape.

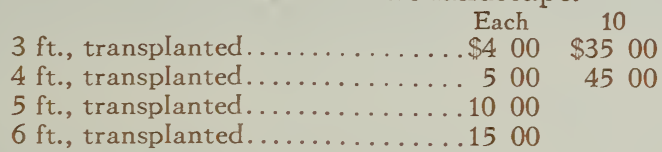

Fir, Douglas' (Abies Douglasii). A Colorado species. Forms a large, spreading pyramid of light green foliage, 80 to 100 feet in height.

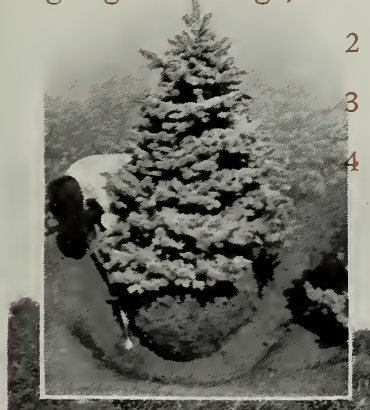

$$
\begin{aligned}
& 2 \text { ft., trans- } \\
& \text { planted ... } \$ 200 \quad \$ 1800 \\
& 3 \text { ft., trans- } \\
& \text { planted ... } 300 \quad 2500 \\
& \text { ft., trans- }
\end{aligned}
$$
planted ... $500 \quad 4500$

Fir, Nikko (Abies bracbyphylla). Comes from Japan and gives promise of being one of our best evergreens. Growth is quite rapid and is suited for background in groups. Each 10 $2 \mathrm{ft}$., transplanted.............. \$4 $00 \$ \$ 3500$ $3 \mathrm{ft}$., transplanted............. $500 \quad 4500$

Fir, White (Abies concolor). The White Fir of the Rocky Mountains is one of the most beautiful species in cultivation, growing 80 to 100 feet in height. It withstands heat and drought better than any other Fir, is very hardy and grows rapidly.

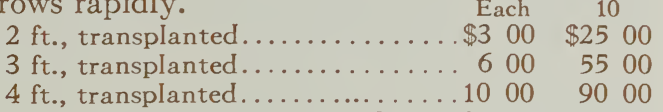

Specimen trees..........\$15 to 2500

Juniper, Glauca (Jiniperus Virginiana glauca). Sometimes called the Blue Juniper; its rich, light blue, silvery foliage makes it attractive the entire season, and is one of the finest blue types of the evergreen family. Each 10

$2 \mathrm{ft}$., transplanted, bushy........\$3 $00 \quad \$ 2500$

$3 \mathrm{ft}$., transplanted, bushy........4 $400 \quad 3500$

$4 \mathrm{ft}$., transplanted, bushy........ $600 \quad 5500$

$5 \mathrm{ft}$., transplanted, bushy........10 00

Specimen trees.........\$10 to 2000

Juniper, Golden (Juniperus Chinensis aurea). A low-growing type, similar in growth to Savin Juniper, except that its foliage is tipped with golden yellow.

$2 \mathrm{ft}$., trans- Each 10

planted .\$3 $00 \$ 2500$

$3 \mathrm{ft}$., trans-

planted . $500 \quad 4500$

Spec. trees.

$\$ 10$ to 1500
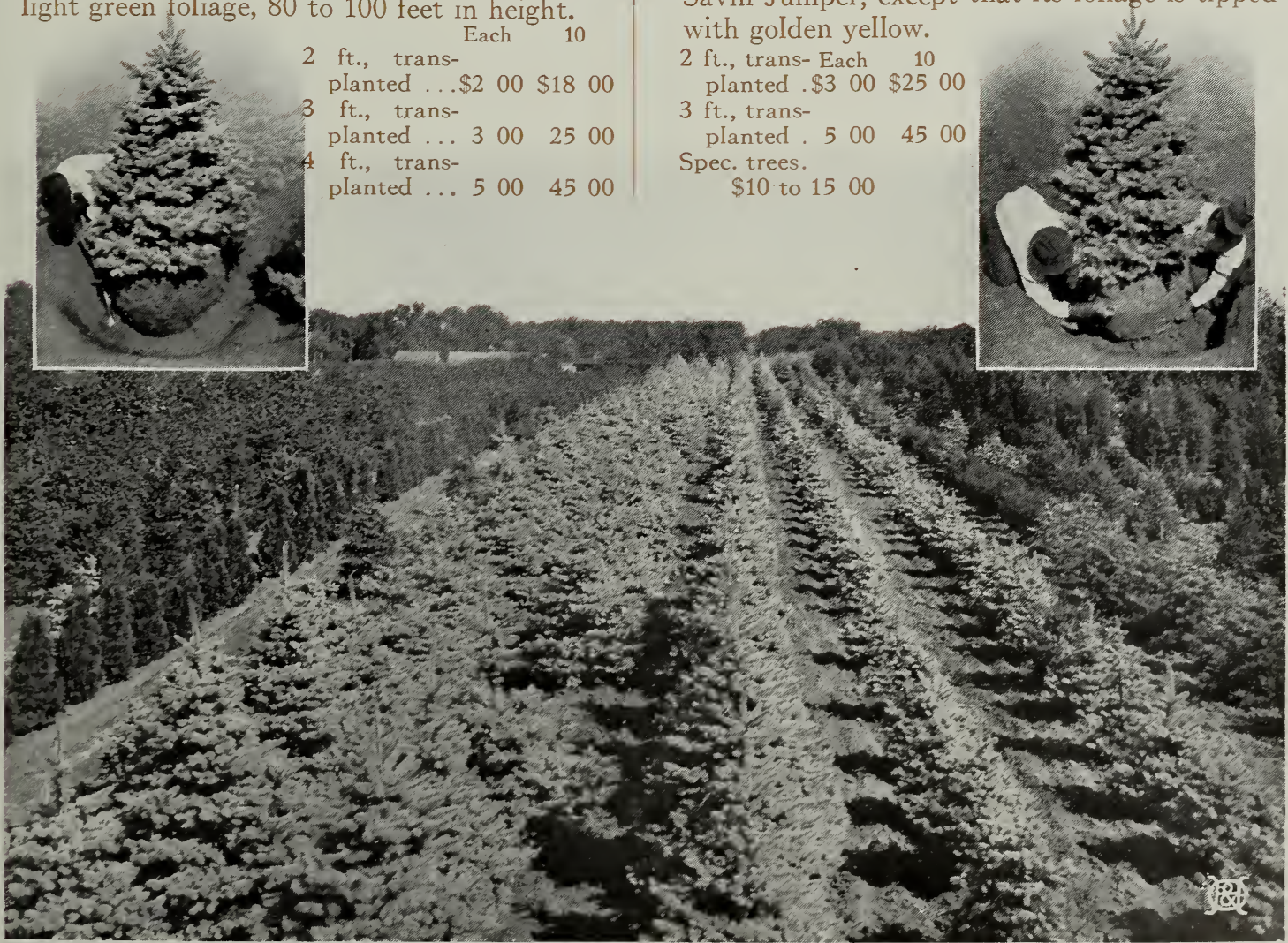

A block of Koster's Blue Spruce from 5 to 8 feet bigh. Note that "H. es O." qualitl, and the manner in wbich they are made ready to ship 


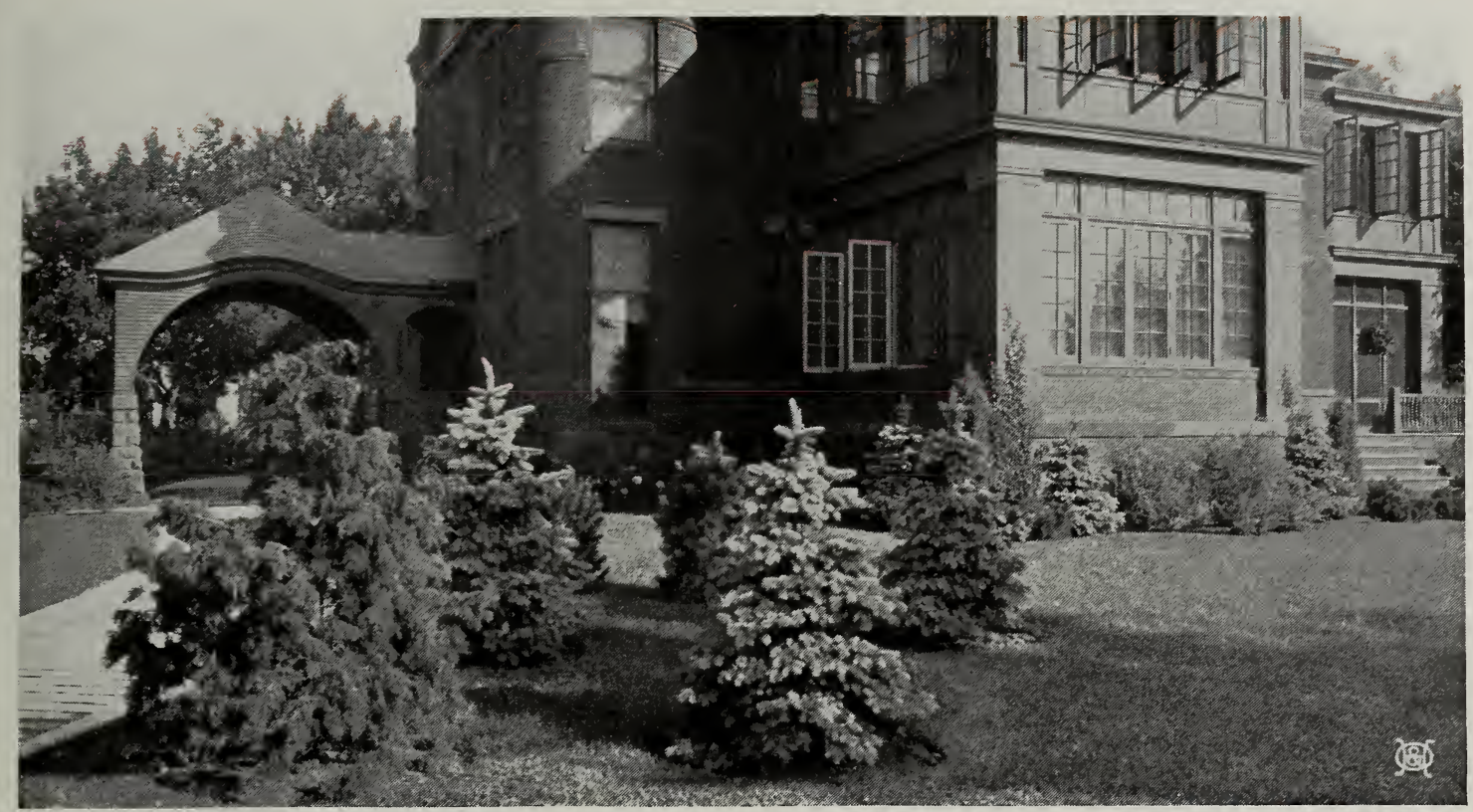

Plantings that are so much admired are results of the knowledge of trees and plants possessed by the H. 0 O. service

EVERGREENS, continued

Juniper, Swedish (Juniperus Suecica). Resembles the Irish Juniper in habit, and is a great acquisition in this climate, owing to its hardiness. Nothing gives the same pyramidal effect as this variety.

Each 10

18 in., transplanted.

$\$ 200 \quad \$ 1800$

Juniper, Trailing (Juniperus procumbens). Planting these trees in groups, they form a mat over the ground. They máke an attractive planting for hillsides or are good for rock-gardens.

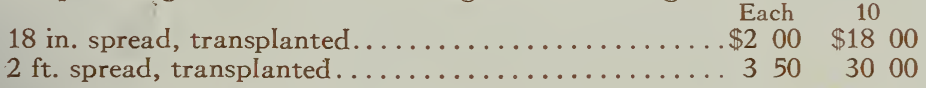

Pine, Dwarf Mugho (Pinus Mugbus). A unique Alpine species, broader than its height and sometimes almost prostrate, forming a dark, dome-shaped bush, 5 to 8 feet high. Used for planting on rocky banks, terrace slopes, smaIl lawns, and particularly effective when grown at the corners of entrances, either singly or in company with other evergreens.

Each 10

12 in., transplanted..........\$1 50 \$1200

18 in., transplanted.............2 $50 \quad 2200$

24 in., transplanted.............. $500 \quad 4500$

Specimen trees ........\$7.50 to 1000

Pine, Swiss Stone (Pinus Cembra). A distinct type, resembling somewhat the White Pine, but its needles are not so long and it is a much better lawn tree. Foliage very dark green. Grows conical and makes an excellent-shaped tree, adding a touch of very attractive color to the winter landscape.

$3 \mathrm{ft}$., transplanted............\$5 $00 \quad \$ 4500$

$4 \mathrm{ft}$., transplanted.............7 $550 \quad 7000$

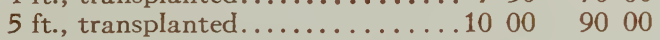

Specimen trees.........\$15 to 2000

Note.-Owing to the presence of White Pine Blister in the eastern sections of the United States, we have concluded not to offer the fivefingered Pines in our Catalog. We have a quantity now, but will stop growing them for the present. 


\section{EVERGREENS, continued}

Spruce, Colorado Blue (Picea pungens). Magnificent, with a silvery blue sheen. Hardy in any exposure, of vigorous growth and elegant habit, with broad branches.

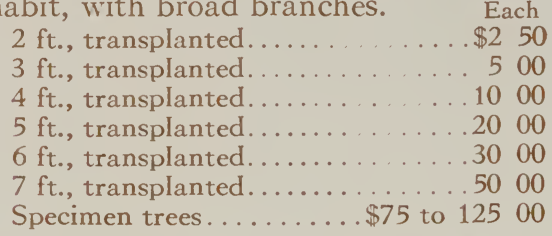

Spruce, Koster's Colorado Blue (Picea pungens Kosteriana). The best and most attractive of the Blue Spruces. Foliage a silvery blue, densely crowded on the many branches. Our blocks of this variety are a sight to behold; they show distinction and quality. Each tree is a specimen of its size. The trees are planted sufficiently far apart that they may develop; have plenty of light and sunshine, making them perfect in shape. Our trees were direct importations from Mr. Koster, the originator; planted in our nurseries, they have developed

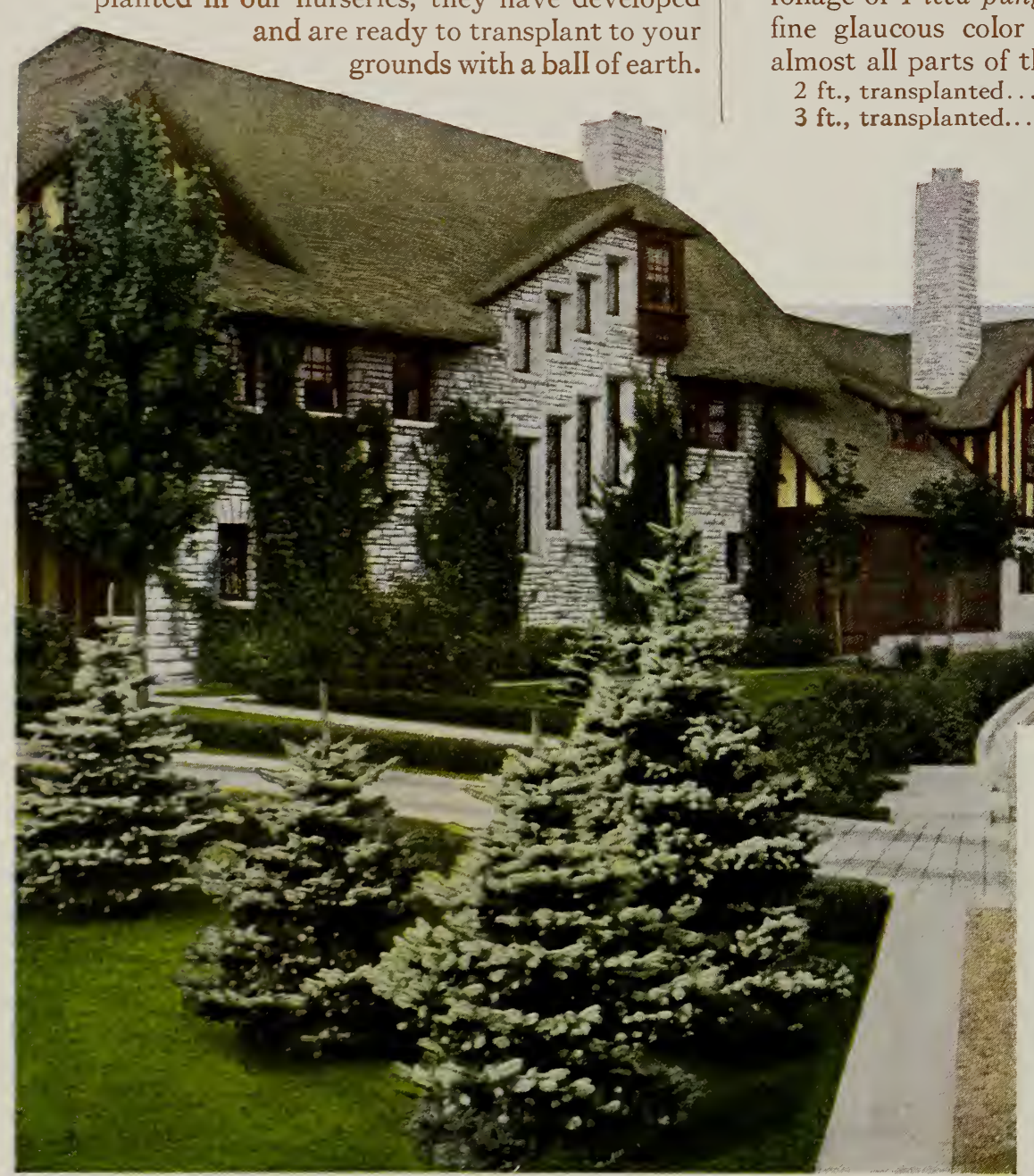

Planned and planted by the H. of O, Landscape Department
Prices of Koster's Spruce

18 in., transplanted.

$2 \mathrm{ft}$., transplanted.

$21 / 2 \mathrm{ft}$., transplanted

$3 \mathrm{ft}$. , transplanted.

$31 / 2 \mathrm{ft}$., transplanted.

$4 \mathrm{ft}$., transplanted.

$41 / 2 \mathrm{ft}$., transplanted.

$5 \mathrm{ft}$., transplanted.

$51 / 2 \mathrm{ft}$., transplanted

$6 \mathrm{ft}$. , transplanted.

Specimen trees.

Each 10

$\$ 300 \quad \$ 2500$

$\begin{array}{llll}500 & 4500\end{array}$

$\begin{array}{llll}750 & 70 & 00\end{array}$

$1000 \quad 9000$

1500

2000

.2500

3000

4000

5000

$\$ 75$ to 15000

Spruce, Black Hills (Picea Canadensis). A handsome, small tree, with slender, pendulous branches; dense and compact; valuable for cold climates and light, dry soils. Each 10

18 in., transplanted.....

$2 \mathrm{ft}$., transplanted.

$3 \mathrm{ft}$., transplanted.

$4 \mathrm{ft}$., transplanted.

Specimen trees

$\begin{array}{llll}\$ 2 & 00 & \$ 18 & 00\end{array}$

$350 \quad 3000$
6

$.600 \quad 5500$

1000

$\$ 15$ to 5000

Spruce, Engelmann's (Picea Engelmanni). A choice and valuable Rocky Mountain tree, of dense, pyramidal growth. Has the stiff foliage of Picea pungens and in most cases the fine glaucous color of the latter. Hardy in Imost all parts of the country. Each 10

$2 \mathrm{ft}$., transplanted............\$3 $50 \quad \$ 3000$ $500 \quad 4500$

$4 \mathrm{ft}$., transplanted, $\$ 10$ each. $5 \mathrm{ft}$., transplanted, $\$ 20$ each. Specimen trees, $\$ 25$ to $\$ 40$ each. 


\section{(1900) SAINT PAUL,MINN. (180)}

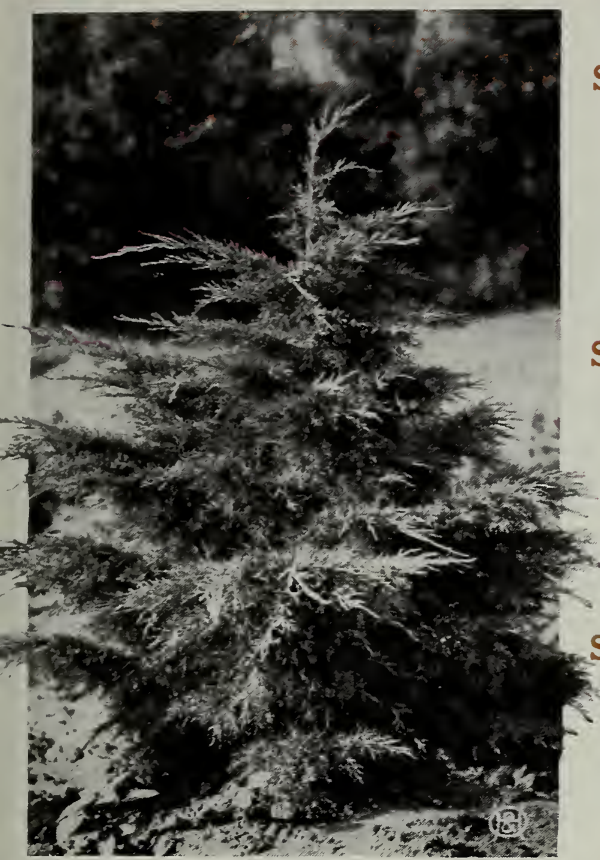

Juniperus Pfitzeriana (see page 20)

EVERGREENS, continued

Spruce, Omorika (Picea Omorika). A new variety from Europe, with foliage silvery underneath; very unique and attractive in appearance.

$2 \mathrm{ft}$. , transplanted $\$ 300 \$ 2500$

$3 \mathrm{ft}$., transplanted $400 \quad 3500$

Specimens. $\$ 10$ to 2000

Spruce, Douglas (Pseudotsuga Douglasii). This is a very hardy evergreen which looks very much like a Spruce but is different botanically. Its habit is symmetrical and quite full.

$2 \mathrm{ft}$., transplanted.

$3 \mathrm{ft}$. , transplanted.

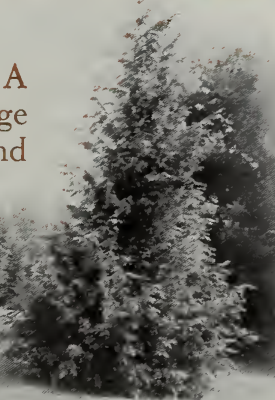

Hemlock Spruce (Tsuga Canadensis)

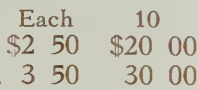

Spruce, Doumett's Black (Picea nigra Doumetti). A dwarf variety of beautiful, dark green, and suited for foreground planting in groups of evergreens. This type is attracting much attention at our nurseries from all interested in this class of plantings. They are valuable for planting close to the buildings, when evergreen effects are wanted. Each 10

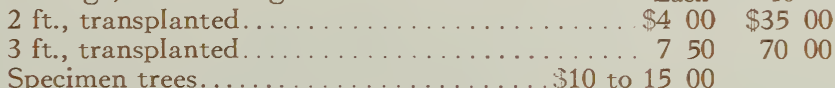

Spruce, Norway (Picea excelsa). The most generally used of evergreen trees. Useful for screens and windbreaks on account of its rapid growth. It makes a tall tree, and, as an individual tree, with room to develop, is of pyramidal, symmetrical growth, its lower branches sweeping the ground.

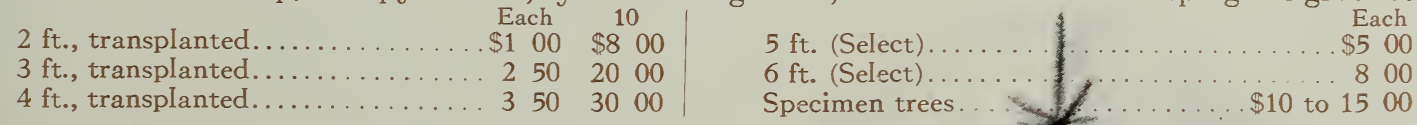

Spruce, White (Picea alba). Compact, upright, long-lived, retaining its branches to the ground; aromatic, droughtresisting; color light green to glaucous blue.

18 in., transplanted.

$2 \mathrm{ft}$., transplanted.

$3 \mathrm{ft}$., transplanted.

$4 \mathrm{ft}$. (Select)....

$5 \mathrm{ft}$. (Select)...

Specimen trees.

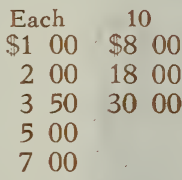

$\$ 10$ to 2500

Yew, Canadian (Taxus Canadensis). Yews grow rather small, like a shrub. Attractive in mass plantings and borders.

12 in., transplanted

15 in transplanted

Each 10

$\$ \begin{array}{llll}\$ 1 & 50 & \$ 12 & 00\end{array}$

$\begin{array}{llll}2 & 00 & 18 & 00\end{array}$

18 in., transplanted

$300 \quad 2500$

Yew, Japanese (Taxus cuspidata brevifolia). Hardier than the English varieties. Foliage beautiful and of irregular outline.

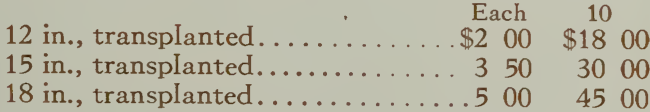

Yew, Spreading (Taxus repandens). This is the hardiest of all prostrate varieties and will grow in almost any location. Rich dark green; excellent for planting on banks. Each 10
12 in., transplanted.
$\$ 200 \quad \$ 1800$
15 in., transplanted.
$\begin{array}{llll}3 & 50 & 30 & 00\end{array}$
18 in., transplanted.
\begin{tabular}{l}
$500 \quad 4500$ \\
\hline
\end{tabular}

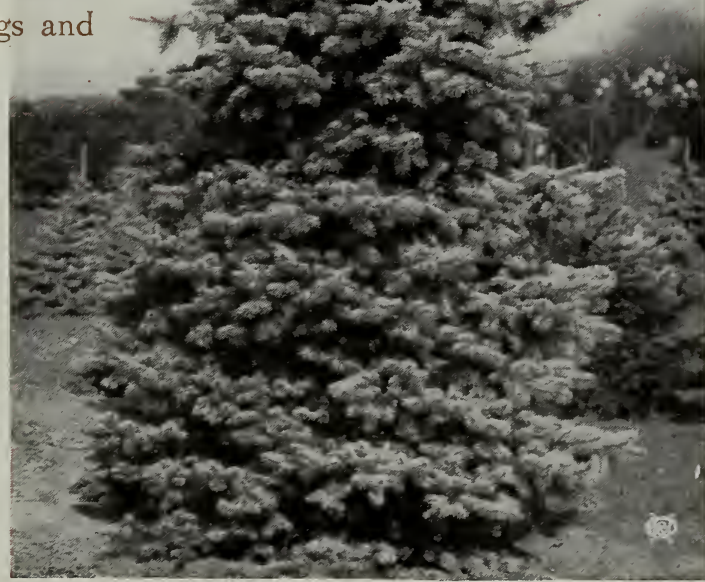

We can transplart large specimens of Koster's Blue Spruce witbout difficulty (see page 22) 

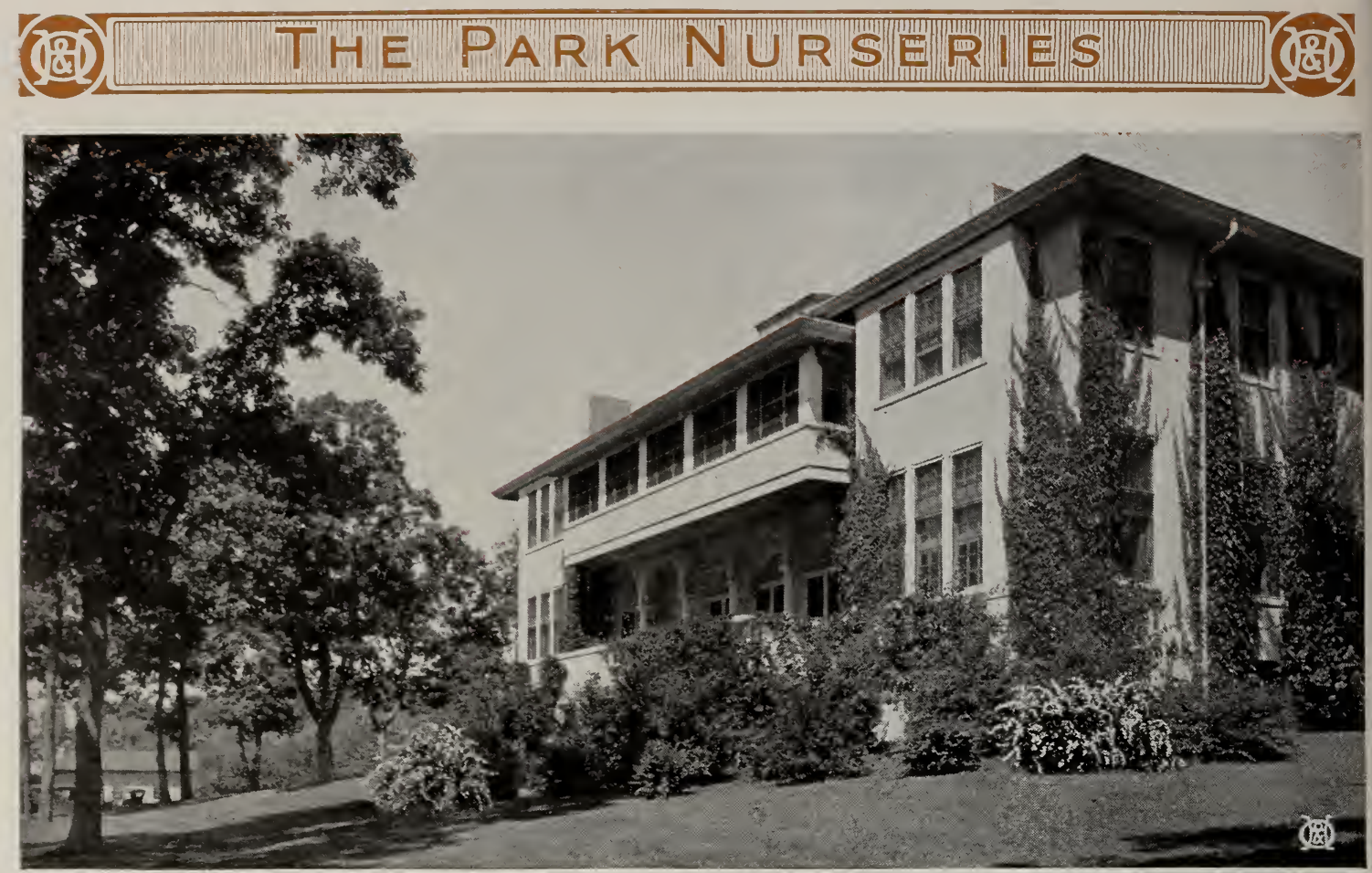

The bome of Mr. A. H. Stem, Dillwood, White Bear Lake
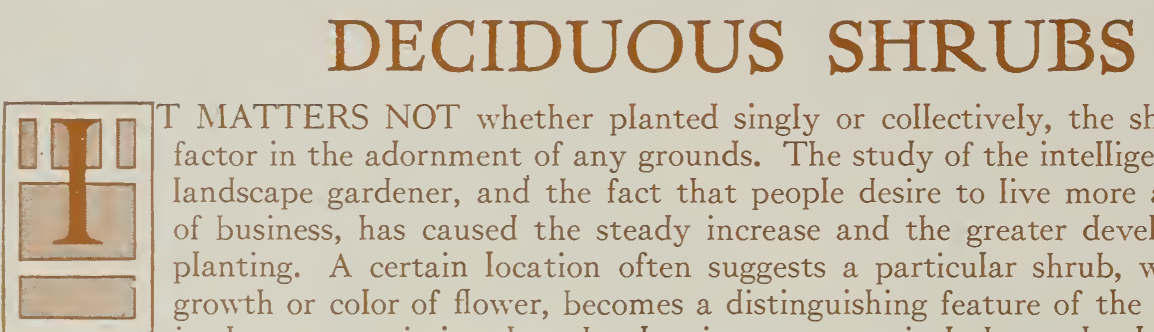

T MATTERS NOT whether planted singly or collectively, the shrub is the important factor in the adornment of any grounds. The study of the intelligent use of these by the landscape gardener, and the fact that people desire to live more away from the center of business, has caused the steady increase and the greater development in the art of planting. A certain location often suggests a particular shrub, which, by its habit of growth or color of flower, becomes a distinguishing feature of the planting. When this is the case, varieties that develop into symmetrical shape should be used. In many locations their gracefulness and beauty are greatly admired.

When groups are formed, they can be made to bring out some feature of the lawn. If the desire is to screen some unsightly object, or to soften some strong or stiff line, such as a fence or hedge, or break the harsh and prominent feature of foundation walls, there is nothing that can take the place of shrubs.

Along the edge of the lawn, drives or walks, plant borders of shrubs that will give flowers in succession, blooming from early spring until frost. Besides these blooming plants, there can be intermingled those of different foliage, such as purple, yellow or golden, and silvery leaves-these add and give contrast as weIl as character to the plantings. After the frosts have come, and the leaves have dropped, the brilliant stems and the fruits and berries that cling to the branches make them very attractive, and add much to the winter's landscape charm. The proper planting of shrubs adds both beauty and value to the grounds. A property judiciously planted is always in demand.

Nursery-row Shrubs. We are asked how they differ from other shrubs. Nursery-row shrubs are those that are planted 6 to 8 inches apart in the row when they come from the seedling or cutting bed. They have one, two and three stems, just what you get from other nurseries.

Transplanted Shrubs. These are the nursery-row plants dug and transplanted into rows, set $11 / 2$ to 2 feet apart, and cut back so they may make a bushy top and a good root-system. It takes two years additional to accomplish this, but we get a plant of more than double value. They transplant with much less loss, and give a great deal better satisfaction. Ask any of our patrons.

Specimen Shrubs. These are large, fully developed plants that give results from the time they are planted. They are moved from time to time, and can be taken up with a ball of earth the same as evergreens. We can supply these in all sizes of most varieties. They range in price from $\$ 1.50$ to $\$ 7.30$ each. 


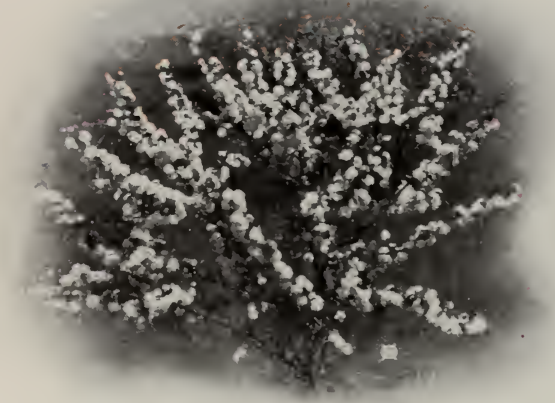

Double Flowering Almond

2 to $3 \mathrm{ft}$., nursery row.

2 to $3 \mathrm{ft}$., nursery row

\section{DECIDUOUS SHRUBS, continued}

Amelanchier alnifolia (Juneberry). White flowers. Suited for wild effects, also for partially shaded places and for shallow, rocky soils.

18 to 24 in., nursery row Each 10

2 to $3 \mathrm{ft}$., nursery row.

\$0 $25 \$ \$ 200$

2 to $3 \mathrm{ft}$., transplanted.

Specimen bushes.

$\$ 1$ to 200

Aralia Chinensis (Dimorphantbus Mandscburicus). Splendid for rocky banks, slopes and mass plantings. Slender, prickly branches. Shining green leaves. Luxuriant, Iustrous foliage until late autumn.

\begin{tabular}{cc|cc} 
Each & 10 & 3 to $4 \mathrm{ft}$., transplanted \\
$\$ 035$ & $\$ 300$ & 4 to $5 \mathrm{ft} .$, transplante $\mathrm{I}$
\end{tabular}

Each 10

$\$ 0$\begin{tabular}{lrr|rr}
35 & $\$ 3$ & 00 & 4 & to $5 \mathrm{ft} .$, transplante $\mathrm{I}$
\end{tabular}

$\$ 100 \quad \$ 800$

$\begin{array}{llll}125 & 1000\end{array}$

Aralia pentaphylla. SIender prickly branches, good crown, and beautiful autumn foliage. Does weII in shady places and can be used under trees. The flowers are a peculiar greenish white, borne in long clusters. The foliage is a rich glossy green, and quite beautiful. The mature plants

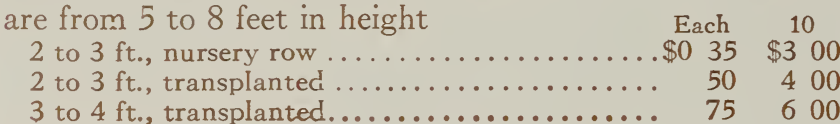

Artemisia Abrotanum (Old Man). This shrub is often used for hedges, growing thick and tall; its foliage somewhat resembles tamarix. Its fragrance is admired by many.

3 to $4 \mathrm{ft}$., transplanted

4 to $5 \mathrm{ft}$., transplanted

Specimen shrubs.

$\$ 075$

100

$\$ 1$ to 200

Barberry, Green (Berberis vulgaris). Vigorous habit; loose, open growth, with quantities of red berries in pendulous clusters in autumn and winter.
18 to 24 in. nursery row.
2 to $3 \mathrm{ft}$., nursery row.
2 to $3 \mathrm{ft}$., transplanted
3 to $4 \mathrm{ft}$., transplanteri.
Specimen shrubs

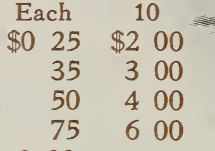
$\$ 1$ to 300

Barberry, Purple (Berberis purpurea). Deep purple foliage all summer. Valuable for color in planting and hedging.

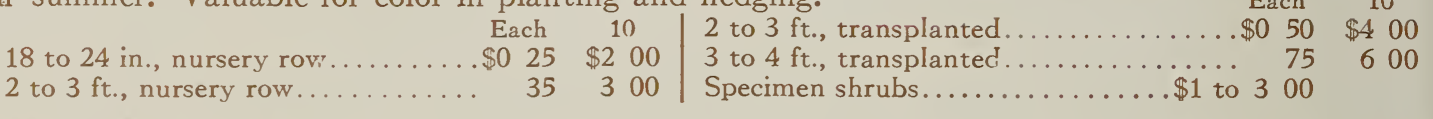

Barberry, Thunberg's (Berberis Thunbergii). A species from Japan, with round, drooping habit, spoon-shaped leaves, of a fine brilliant green in summer, with the growing shoots always of a lighter shade, and taking on, from early autumn till December, the most glowing colors. After the leaves faII, the branches are seen to be loaded down with scarlet-crimson berries. It is the very best of aII plants to form a hedge of 5 feet, being impenetrable and thickly set with spines, and never growing bare. Even in winter its closely interwoven branches and twigs are very interesting.

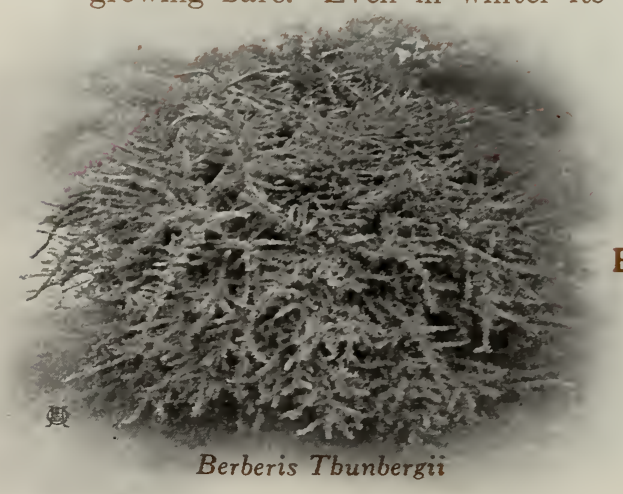

See, also, Deciduous Hedges.

12 to 18 in., nursery row.

18 to 24 in., nursery row.

18 to 24 in., transplanted

24 to 30 in., transplanted

30 to 36 in., transplanted

Specimen bushes.

$\ldots \ldots \$ 1$ to 200

Barberry, Japanese (Berberis Japonica). A type similar to Thunberg's, but has a more varied foliage, the new growth being a light green and more showy; otherwise the bush is nuch the same.

24 to 30 in., transplanted.

30 to 36 in., transplanted

Specimen shrubs.

Each 10

$\$ 100 \quad \$ 800$

$\begin{array}{llll}1 & 50 & 12 & 50\end{array}$

$\ldots \$ 2$ to 250 


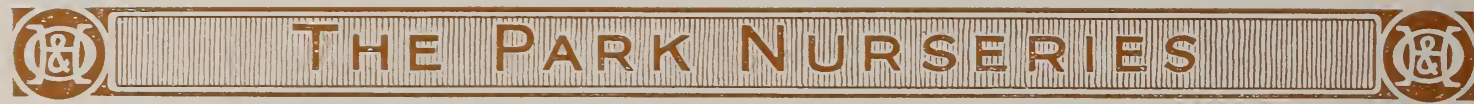

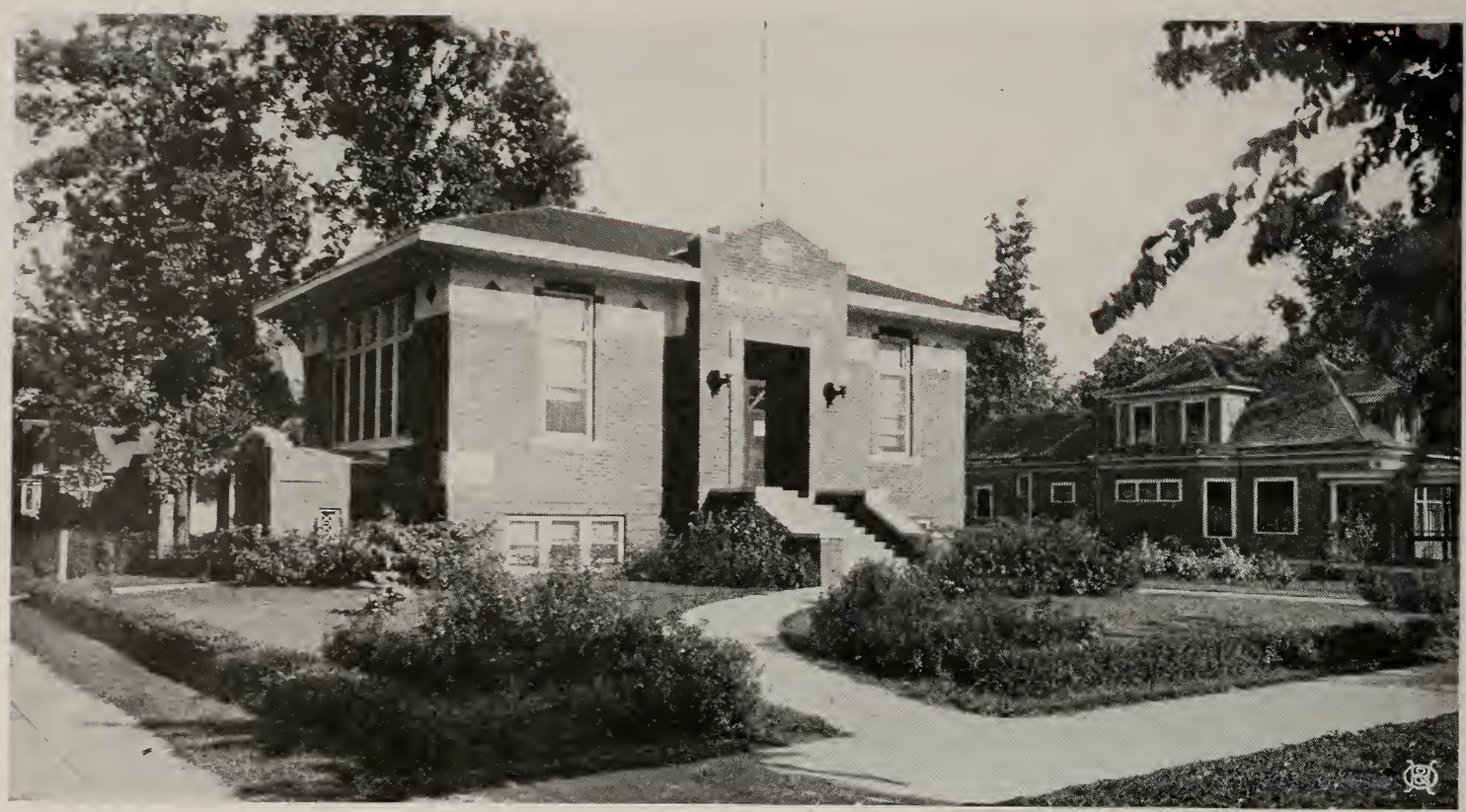

Public Library and grounds at White Bear Minn.- Are the grounds around your town Library as bandsome as these?

\section{DECIDUOUS SHRUBS, continued}

Deutzia, Pride of Rochester. A showy, early and large-flowering sort, that blooms in May before the others. Grows 6 to 8 feet tall. The white flowers are large and double. Each

18 to 24 in., nursery row.

2 to $3 \mathrm{ft}$., nursery row

2 to $3 \mathrm{ft}$., transplanted.

3 to $4 \mathrm{ft}$., transplanted.

Specimen shrubs....

$\$ 025 \$ 200$

35300

$50 \quad 400$

$75 \quad 600$

$\$ 1$ to 200

Dogwood, Silver (Cornus Sibirica variegata). A large, spreading shrub, 6 to 10 feet high, with clusters of white flowers in June, variegated foliage and coral-red bark. Nothing is more attractive in a shrub border; its white and light green leaves, so different from those of other

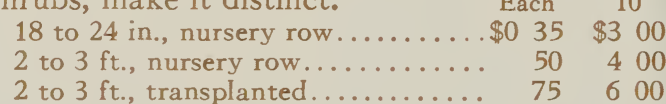

$\begin{array}{rrrr}2 & \text { to } 3 \mathrm{ft} \text {., transplanted............... } 75 & 6 & 00 \\ 3 \text { to } 4 \mathrm{ft} \text {, transplanted........ } & 00 & 8 & 00\end{array}$

Dogwood, Golden (Cornus Gouchaulti aurea). The foliage is richly marked with yellow. Distinct and valuable on account of the rich color of the foliage variegation.

18 to 24 in., nursery row.

2 to $3 \mathrm{ft}$., nursery row...

2 to $3 \mathrm{ft}$., transplanted.

Each 10

$\$ 035 \$ 300$

$50-400$

75600

Dogwood, Golden Bark (Cornus aurea). The stems are a bright golden yellow in the faII and winter, making a vivid contrast with the Siberian, which is crimson. The habit of the bush is more spreading, and foliage is about the same.

2 to $3 \mathrm{ft}$., nursery row.

2 to $3 \mathrm{ft}$., transplanted.

3 to $4 \mathrm{ft}$., transplanted

Specimen shrubs.

Each

$\$ 0 \quad 35 \$ 300$

$50-400$

75600

$\$ 1$ to 200
Dogwood, Panicled (Cornus paniculata). This bush is formed of gray branches, making it distinct as to coloring of stems. The flowers are small and white and borne very profusely in great panicles early in spring. It grows quite compact and is covered with white berries in fall, which persist for a long time, making the winter effect very pleasing.

18 to 24 in

2 to $3 \mathrm{ft}$., nursery row.......... $35 \quad 300$

2 to $3 \mathrm{ft}$., transplanted............. 50.400

3 to $4 \mathrm{ft}$., transplanted............ 75 . 600

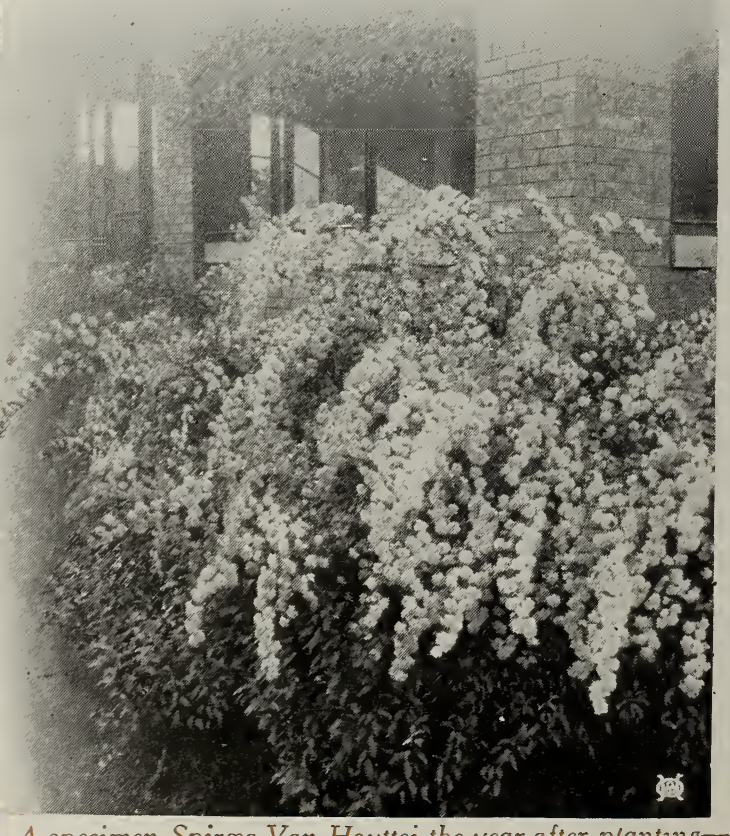

A specimen Spiræa Van Houttei the vear after plantzng- 


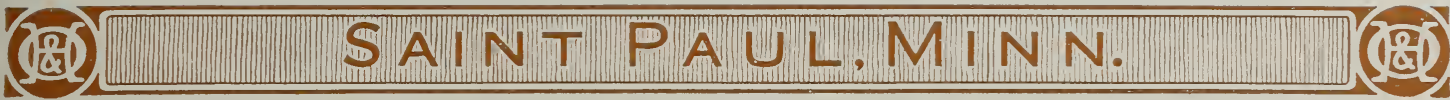

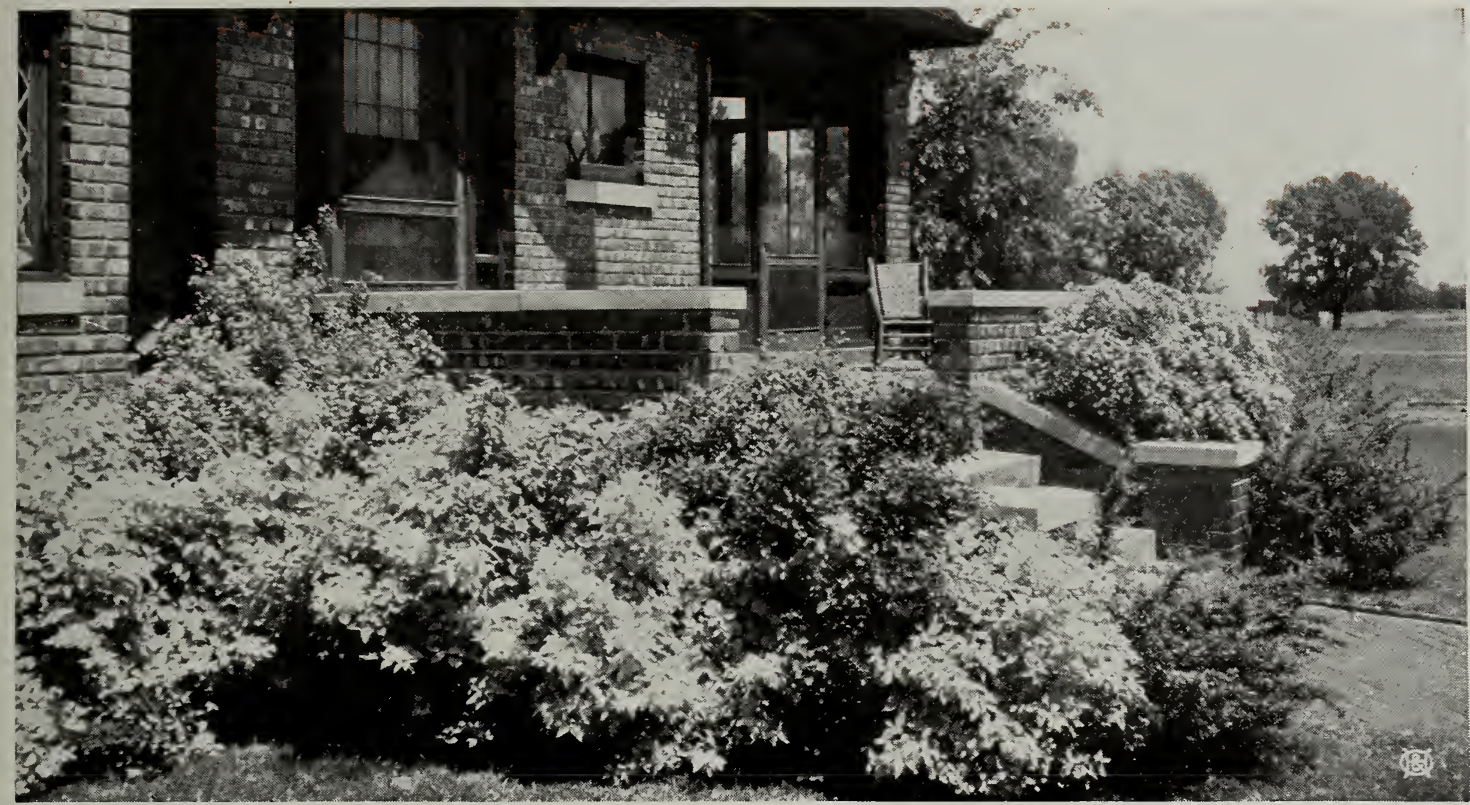

Shrubs of medium beight in the foreground, with taller growers against the bouse, barmonize with this type of bouse

\section{DECIDUOUS SHRUBS, continued}

Dogwood, Red-twigged (Cornus Sibirica alba). Free-growing, 6 to 10 feet tall, and very hardy; forms a smaII, handsome tree in some situations. Its clusters of smaIl, white flowers in early summer are very dainty, and its bark is a showy, dark red in spring. AII the Siberian Dogwoods bear in early fall a profusion of whitish blue berries, making them distinctly ornamental after the

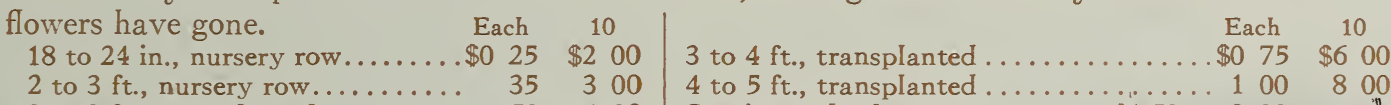

Dogwood, Red Osier (Cornus stolonifera). A medium-sized, spreading shrub, with dark red bark

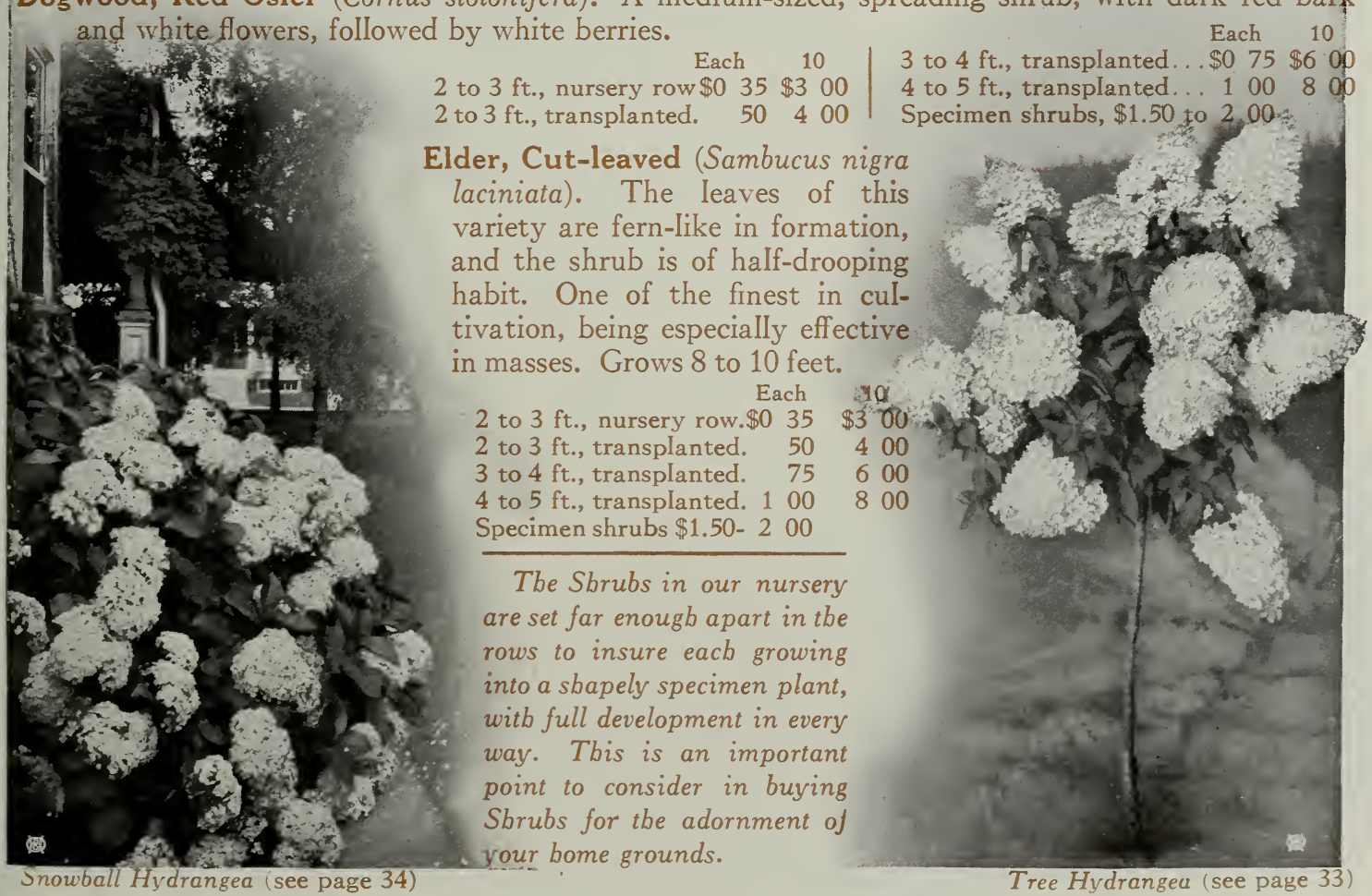




\section{(19id) THE PARK NURSERIES (18)}

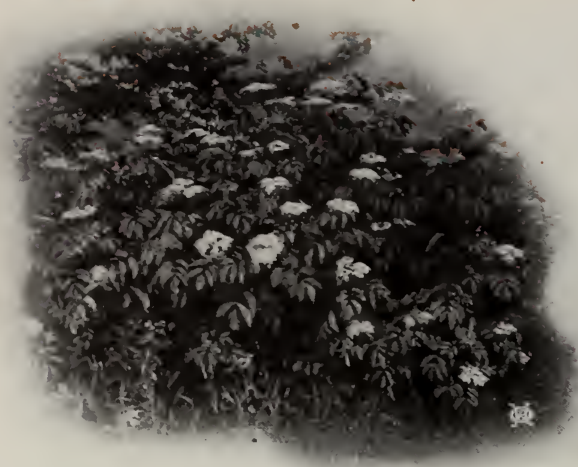

Cut-leaved Elder (see page 29)

\section{DECIDUOUS SHRUBS, continued}

Elder, Golden (Sambucus aurea). Contrasted with other shrubs, the golden yellow leaves of this Elder give heightened effects in tone and color. Flowers white, in flattopped cymes in early summer. It can be pruned into a neat, compact little bush, or grows naturally to 10 to 15 feet. $\quad$ Each 10

2 to $3 \mathrm{ft}$., nursery row................. \$0 $35 \$ \$ 300$

2 to $3 \mathrm{ft}$., transplanted................... $50 \quad 400$

3 to $4 \mathrm{ft}$., transplanted.................. $75 \quad 600$

4 to $5 \mathrm{ft}$., transplanted................. $100 \quad 800$

Specimen shrubs...............\$1.50 to 250

Elder, Golden Plume (Sambucus plumosa aurea). Beautiful, golden, finely divided, fern-like foliage.

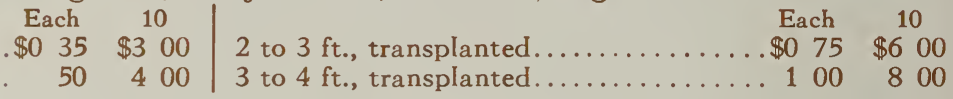

18 to 24 in., nursery row.

2 to $3 \mathrm{ft}$., nursery row.

Elder, Red-berried (Sambucus racemosus). Of somewhat stockier growth than the other varieties,
with white flowers in cymes, followed by red fruits. The foliage is particularly graceful and handsome. Blooms in early summer, and the berries are very much relished by the birds. Each 10

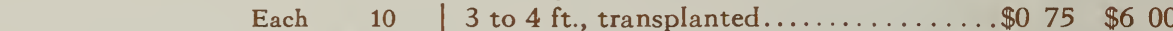
2 to $3 \mathrm{ft}$., nursery row..........\$0 $35 \$ \$ 300 \quad 4$ to $5 \mathrm{ft}$., transplanted............. $100 \quad 800$

2 to $3 \mathrm{ft}$., transplanted.......... $50 \quad 400$ Specimen shrubs...........\$1.50 600

Elder, Variegated (Sambucus variegata). A variety with green-andyellow foliage; good for borders of shrubbery.

2 to $3 \mathrm{ft}$., nursery row.

2 to $3 \mathrm{ft}$., transplanted.

3 to $4 \mathrm{ft}$., transplanted

4 to $5 \mathrm{ft}$., transplanted.

Specimen shrubs.

Euonymus Americana (Burning Bush). A very ornamental and showy shrub, whose chief beauty consists in its brilliant rose-colored berries, which hang in clusters from the branches until midwinter.

2 to $3 \mathrm{ft}$., nursery row.

2 to $3 \mathrm{ft}$., transplanted.

3 to $4 \mathrm{ft}$., transplanted.

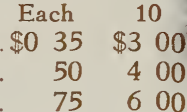

Euonymus, Corkbark (Euonymus elatus). A shrub different in character from others, having an individuality of its own. It is particularly ornamental and interesting on account of its curious corky bark. The small, delicate flowers of the spring are followed by attractive red berries in the fall. It is also valuable on account of its autumn foliage, which is scarlet, and favorably commented on by all that see it. Suitable for groups or individual planting. Each 10
2 to $3 \mathrm{ft}$., transplanted.
\begin{tabular}{ll|l} 
Each 10 & 3 to $4 \mathrm{ft}$., transplanted.
\end{tabular}
$\$ 150 \$ 1250 \quad$ Specimen shrubs..
$\$ 3$ to 500

2000

Elæagnus argentea (Russian Olive). Leaves are particularly handsome, willow-like and a rich, silvery white; flowers are smaII, golden yellow and fragrant, followed by yellow fruit covered with silyex segls. A most valuable hedge plant on account of its resistance to cold, heat and drought,

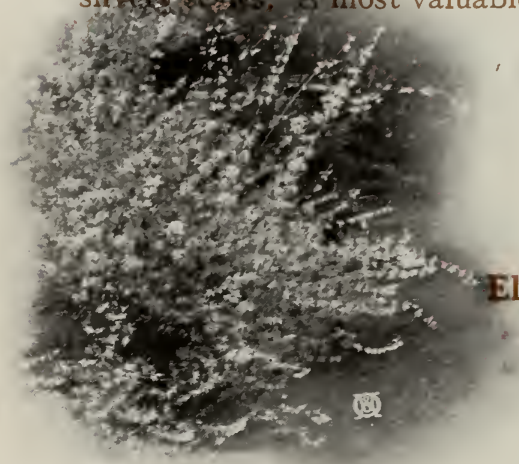

Goiden Bell (see page 31) and is a fine shrub for farm fences. See under Deciduous Hedges.

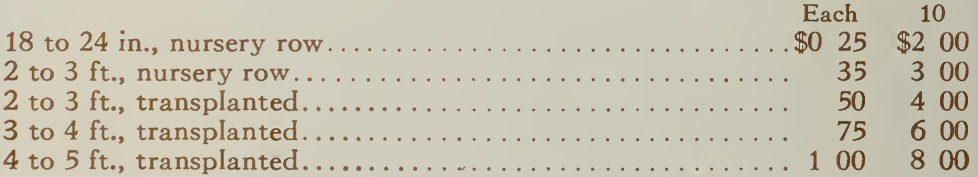

Specimen shrubs........................... $\$ 1.50$ to 500

læagnus angustifolia. An open bush, with narrow, silvery leaves and fragrant yellow flowers, followed by yellow fruits, which are sometimes used for jellies, etc.

18 to 24 in., nursery row..................... $\$ 025 \$ 200$

2 to $3 \mathrm{ft}$, nursery row........................ 35,300

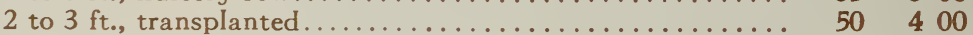

3 to $4 \mathrm{ft}$., transplanted ....................... $75 \quad 600$ 


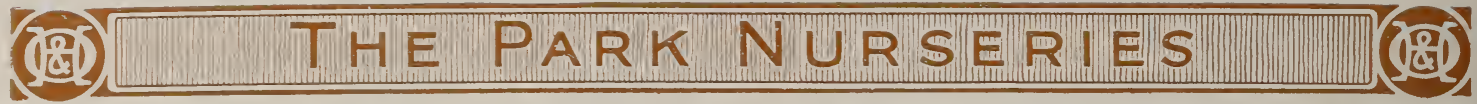

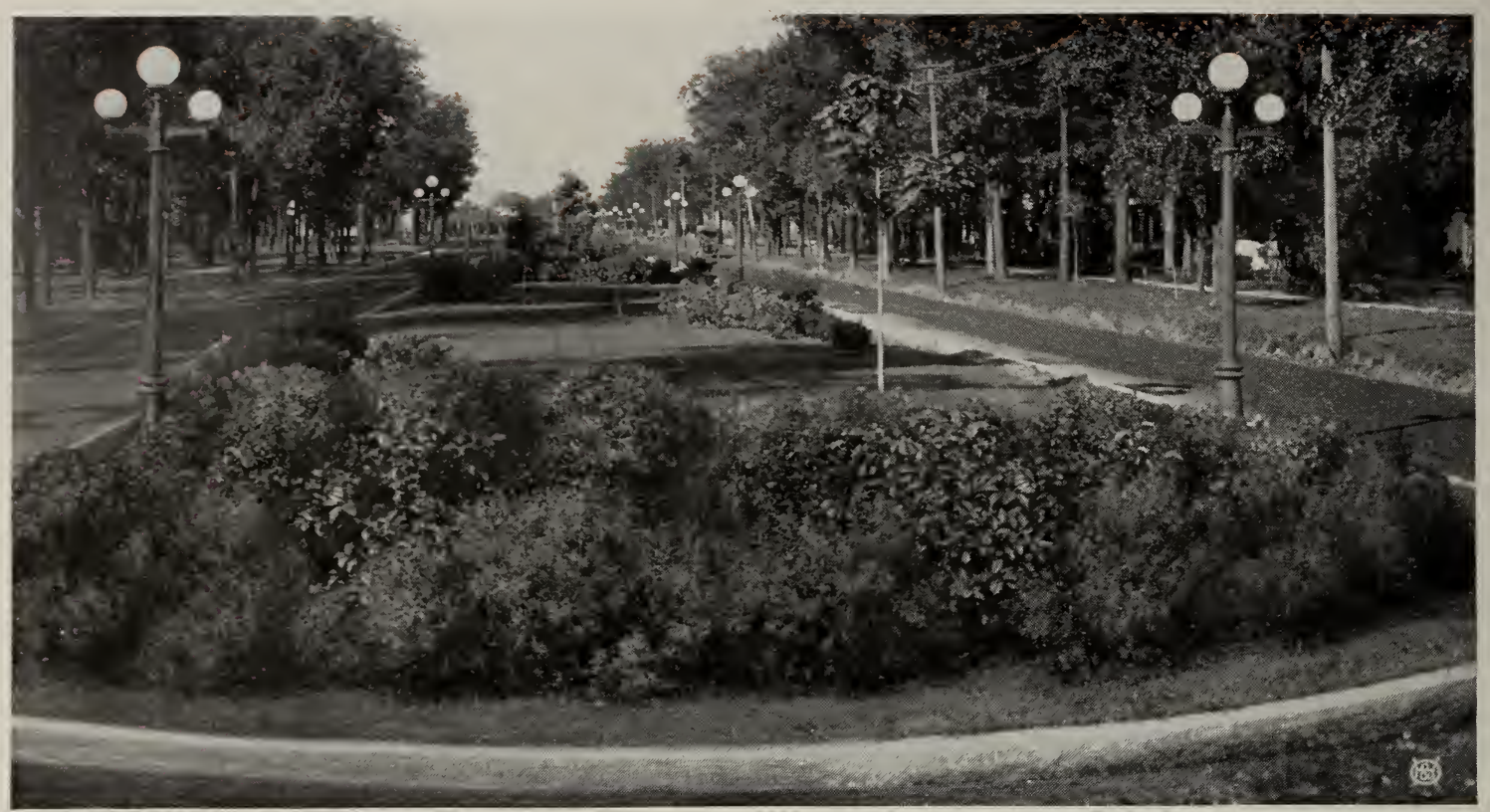

An arrangement of a street parkway at White Bear. Planned by H. \& O. Service

DECIDUOUS SHRUBS, continued

Honeysuckle, Red Tartarian (Lonicera Tatarica). 8 to 10 feet tall. In spring its pink flowers contrast beautifully with its green foliage, but its chief charm is its orange or red berries which cover the plant in summer and autumn. Each $10 \quad$ Each 10 18 to 24 in., nursery row..........\$0 $25 \$ \$ 200 \quad 3$ to $4 \mathrm{ft}$., transplanted.............. \$0 $75 \$ \$ 600$ 2 to $3 \mathrm{ft}$., nursery row........... $35 \quad 300 \quad 4$ to $5 \mathrm{ft}$., transplanted.............. $100 \quad 800$

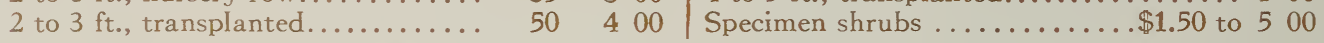

Honeysuckle, Pink Tartarian (Lonicera rosea). Bears a profusion of pink flowers. Otherwise the same as the red. Each 10 Each 10 18 to $24 \mathrm{in}$., nursery row.........\$0 $25 \$ \$ 200 \quad 3$ to $4 \mathrm{ft}$., transplanted.............\$0 $75 \$ \$ 600$

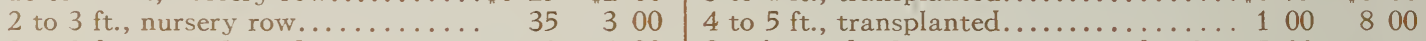

2 to $3 \mathrm{ft}$, transplanted........... $50 \quad 400$ Specimen shrubs..........\$1.50 to 500

Honeysuckle, White Tartarian (Lonicera alba). A beautiful, tall bush, with creamy white flowers in May and June. Like the others, it bears great ropes of brilliant red berries in late Each
Summer.

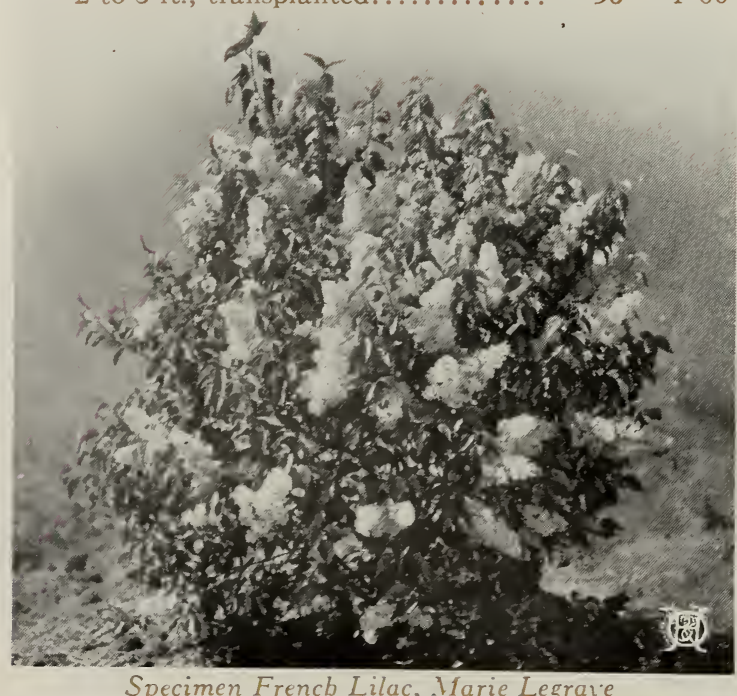
Specimen shrubs........... \$1.50 t9 400

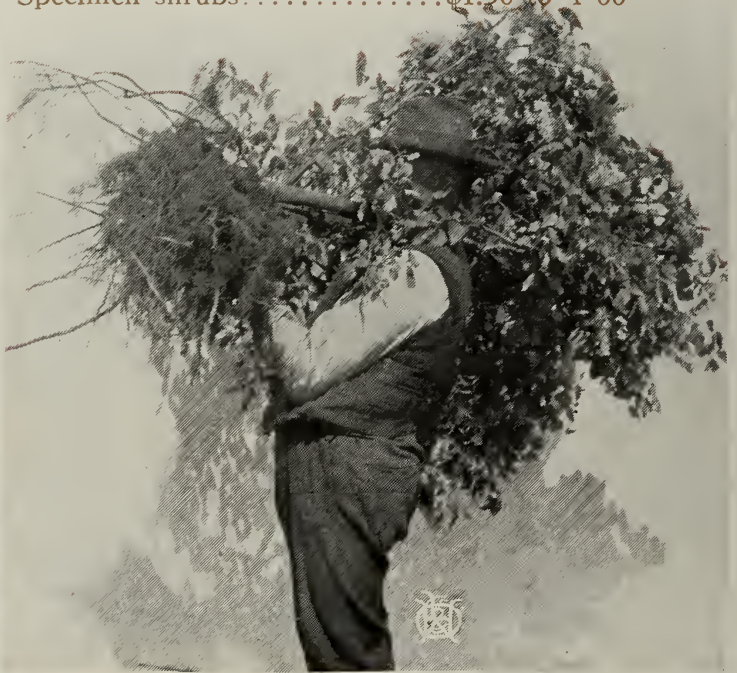

Specimen Frencb Lilac, .Marie Legraye 


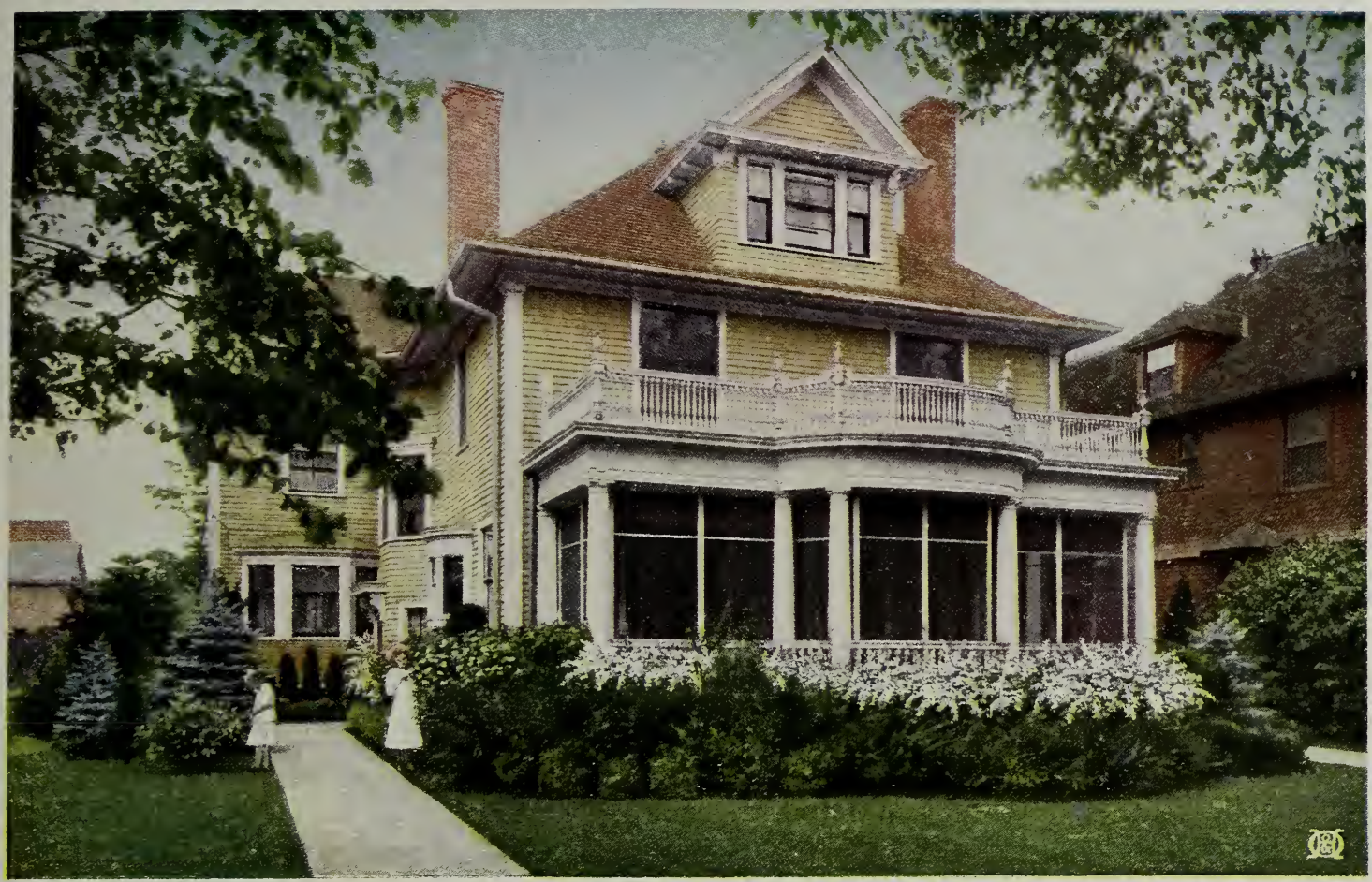

Thunberg's Barberry and Spiræa Van Houttei are two of the best shrubs for foundation plantings

DECIDUOUS SHRUBS, continued

Honeysuckle, Morrow's (Lonicera Morrowi). Grows only 4 to 6 feet, tall and spreading. It is valued chiefly for the brilliant red fruits which appear in August.

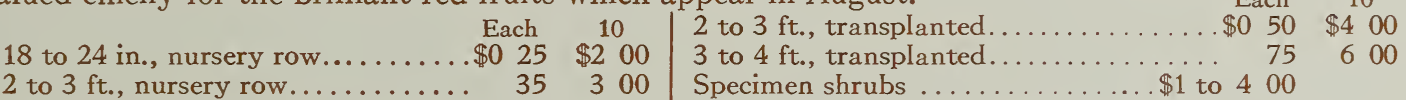

Horse-Chestnut, Dwarf (Esculus parviflora). A dwarf variety of Horse-Chestnut, which grows in shrub form, making a fine specimen and valuable for groups.

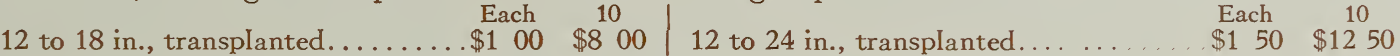

Hydrangea, Large-flowered (Hydrangea paniculata grandiflora). Bush form. One of the most conspicuous shrub in any collection during August and September. Its plumes of white flowers bend the branches with their weight, changing finally to pink and bronzy green.

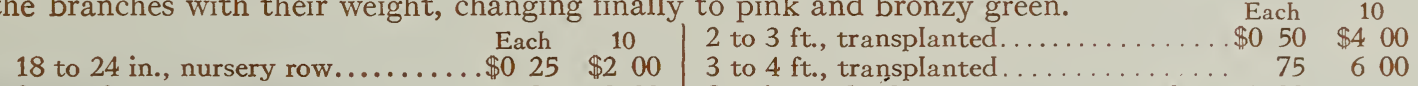
2 to $3 \mathrm{ft}$., nursery row...
\begin{tabular}{ll|l}
35 & 300 & Specimen shrubs
\end{tabular}
$\$ 1$ to 200

Hydrangea, Tree. Same as the former, but grown in tree form, and bears great trusses of flowers.

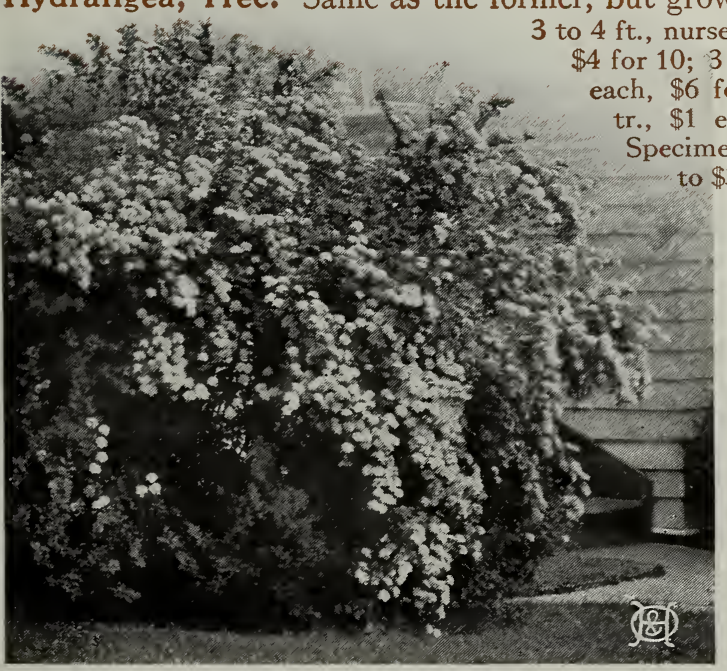

A graceful planting for side entrance
$\$ 4$ for $10 ; 3$ to $4 \mathrm{ft} .$, tr., $75 \mathrm{cts}$.

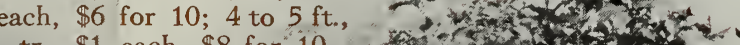

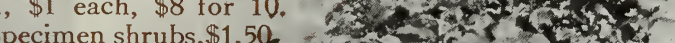

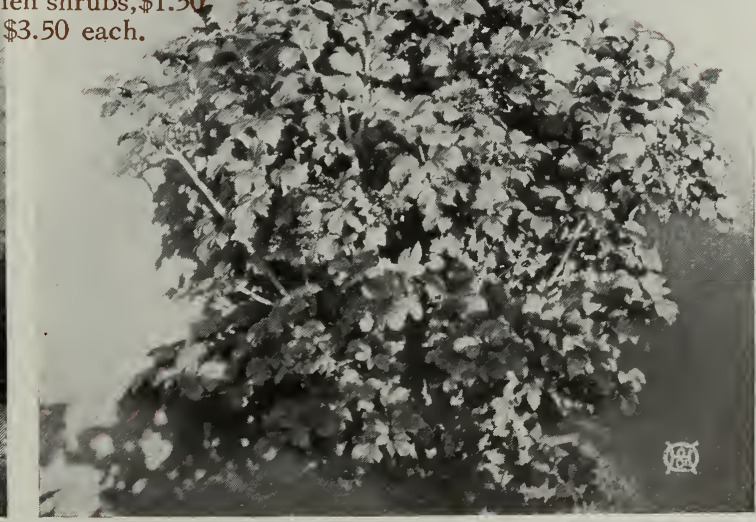

The High-bush Cranberry in bloom (see page 36) 


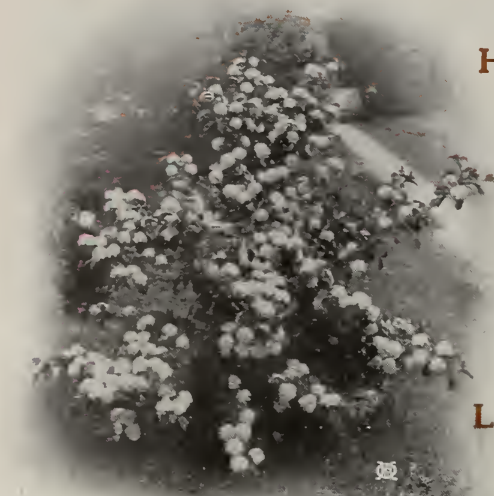

Common Snowball or Viburnum Opulus sterile (see page 35 )

\section{DECIDUOUS SHRUBS, continued}

Hydrangea arborescens grandiflora (Everblooming Snowball Hydrangea). This new American Hydrangea is believed to be the most beautiful hardy flowering shrub ever introduced. It blooms from early June till toward autumn frosts. The plant attains a height of 5 to 6 feet, with nearly the same breadth, and bears large trusses of beautifully formed flowers of dazzling whiteness, rendering this a plant of flawless beauty.
18 to 24 in., nursery Each
row.........\$ 50
10
$\$ 400$
600
Each
$\$ 800$

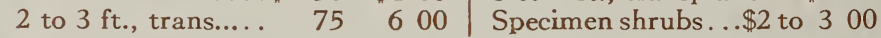

Lilac, Common Purple (Syringa vulgaris). The familiar species of all fine old gardens, with dense panicles of lilac flowers in May.
18 to 24 in., nursery Each
row.
$\$ 025$
$\begin{array}{rl}\$ 2 & 00 \\ 3 & 00 \\ 4 & 00\end{array}$
3 to $4 \mathrm{ft}$., trans........
4 to $5 \mathrm{ft}$., trans.....
Specimen shrubs, $\$ 1.50$
Each 10
2 to $3 \mathrm{ft}$., nursery row. 35
$\$ 075 \quad \$ 600$
2 to $3 \mathrm{ft}$., trans.

Lilac, Common White (Syringa vulgaris alba). Similar to above with pure white, fragrant flowers.

Each 10

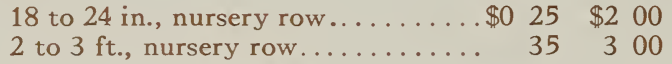

2 to $3 \mathrm{ft}$., transplanted........... $50 \quad 400$

3 to $4 \mathrm{ft}$., transplanted................ $75 \quad 600$

4 to $5 \mathrm{ft}$., transplanted........... $100 \quad 800$

Specimen shrubs........\$1.50 to 500

Lilac, Persian (Syringa Persica). Its pale lilac flowers are very fragrant, and borne in Iarge, loose panicles in late spring.

18 to 24 in., nursery row.

Each 10

2 to $3 \mathrm{ft}$., nursery row.

2 to $3 \mathrm{ft}$., transplanted.

3 to $4 \mathrm{ft}$., transplanted

4 to $5 \mathrm{ft}$., transplanted

Specimen shrubs

$\$ 0 \quad 25 \$ 200$

35300

$50 \quad 400$

75600

$\begin{array}{lll}100 & 800\end{array}$

Lilac, White Persian (Syringa Persica alba). Of similar habit to the former, with white flowers.

2 to $3 \mathrm{ft}$., nursery row.

2 to $3 \mathrm{ft}$., transplanted

3 to $4 \mathrm{ft}$., transplanted

Specimen shrubs

Each 10

$\$ 0 \quad 35 \$ 300$

$60 \quad 500$

$\begin{array}{lll}1 & 00 & 800\end{array}$

Lilac, Giant Tree (Syringa Japonica). The only tree form in the group, growing to 30 feet high. Blooms in June and July, with Iong, white, showy flower-plumes.

2 to $3 \mathrm{ft}$., nursery row
2 to $3 \mathrm{ft}$., transplanted.

3 to $4 \mathrm{ft}$., transplanted

4 to $5 \mathrm{ft}$., transplanted

Specimen shrubs

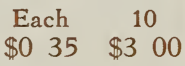

$50 \quad 400$

75600

$\begin{array}{lll}100 & 800\end{array}$

Lilac, Hungarian (Syringa Josikæa). Purple flowers in June after other Lilacs have done flowering.

2 to $3 \mathrm{ft}$., nursery row.

2 to $3 \mathrm{ft}$., transplanted

3 to $4 \mathrm{ft}$., transplanted

Specimen shrubs

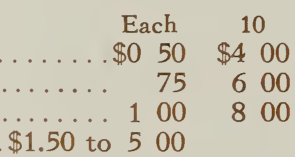

Lilac, Himalayan (Syringa villosa). A bushy shrub, with pinkish lilac flowers in long, slender panicles.

2 to $3 \mathrm{ft}$., nursery row

2 to $3 \mathrm{ft}$., transplanted.

3 to $4 \mathrm{ft}$., transplanted

Specimen shrubs.

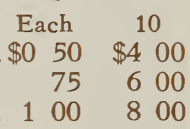

$\$ 1.50$ to 400

\section{NAMED FRENCH VARIETIES OF LILACS}

The named sorts are much superior to the old type of Common Purple and White and bloom much earlier.

2 to $3 \mathrm{ft}$., transplanted.

Each 10

3 to $4 \mathrm{ft}$., transplanted............. $100 \quad 800$

4 to $5 \mathrm{ft}$., transplanted.......... $150 \quad 1250$

Specimen shrubs.......\$1.50 to 500

4 to $5 \mathrm{ft}$., tree form.......... $150 \quad 1250$

Specimen trees ........... $\$ 2$ to 300

Alphonse Lavallee. Fine blue, shaded violet.

Belle de Nancy. Satiny rose, white center.

Charles X. Reddish purple; large.

Dr. Masters. Clear lilac; superb.

Ludwig Spaeth. Dark purplish red; superb.

Marie Legraye. One of the finest white Lilacs.

Michael Buchner. Dwarf; pale lilac.

Madame Lemoine. Fine, double, white Lilac.

President Carnot. Pale blue.

President Grevy. A beautiful blue.

President Viger. Bluish lilac; extra.

Rubra de Marly. Purplish red; fine.

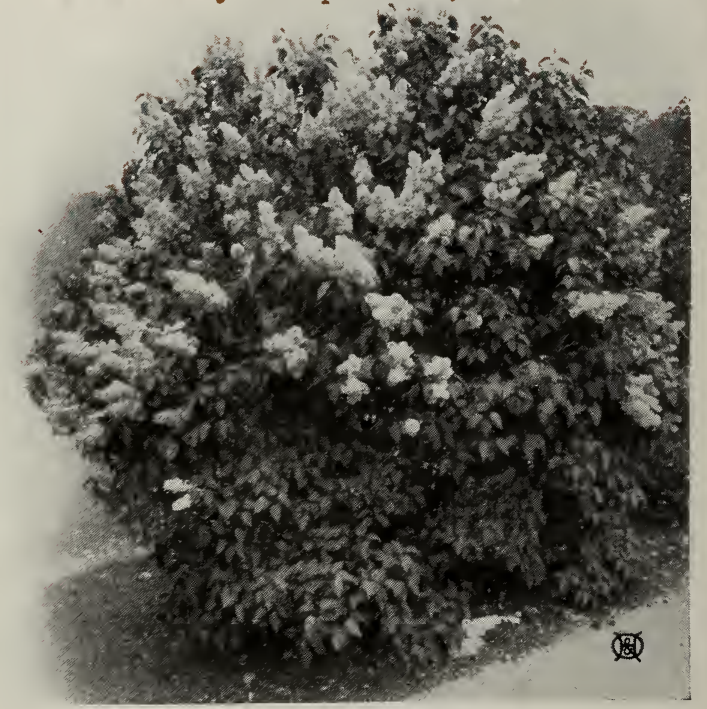

Madame Lemoine Lilac-large clusters of double white flowers 
DECIDUOUS SHRUBS, continued

Locust, Pink (Robinia hispida). Is valued for its elegant rose-colored flowers, in Iong, wisteria-like racemes, which expand toward the close of May.

2 to $3 \mathrm{ft}$., transplanted.

3 to $4 \mathrm{ft}$., transplanted.

Each 10

Specimen shrubs

$\$ 0 \quad 50 \quad \$ 400$

75600

Matrimony Vine (Lycium Chinense). A vigorous, hardy, climbing plant, with bright purple flowers, which are succeeded by brilliant scarlet berries. Fine for drooping over walls or growing on a trellis.

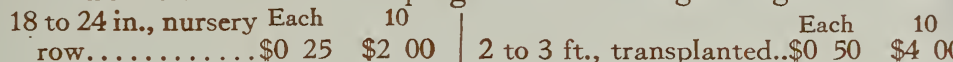

2 to $3 \mathrm{ft}$., nursery $\quad 3$ to $4 \mathrm{ft}$., transplanted.. $75 \quad 600$

row........... $35 \quad 300 \quad$ Specimen shrubs..\$1 to 200

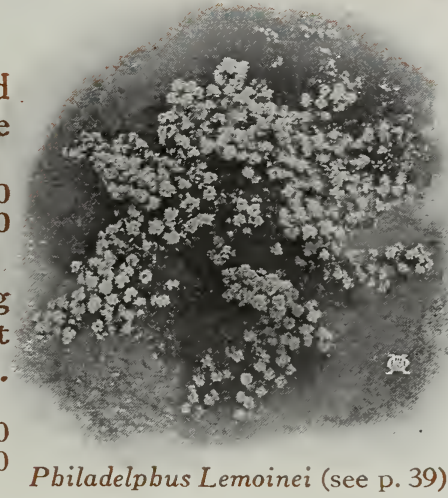

Plum, Double-flowering (Prunus triloba). The large, double, pink flowers resemble roses, and are crowded along the slender branches.

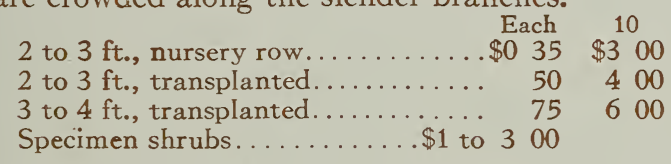

Potentilla fruticosa. Blooms all summer and, being of a dwarf habit, it is a suitable shrub for outside border plantings. Flowers are bright yellow.

12 to 18 in., nursery row........ $\$ 0 \quad 35 \quad \$ 300$

18 to 24 in., transplanted......... $50 \quad 400$

Privet, Regel's (Ligustrum Regelianum). Branches dense and droop gracefully, giving this variety a distinctly attractive appearance. In autumn the foliage turns a dark red. This plant is unexcelled for shrubbery borders and masses, park planting and hedges. The plants are strong growers and in many places are

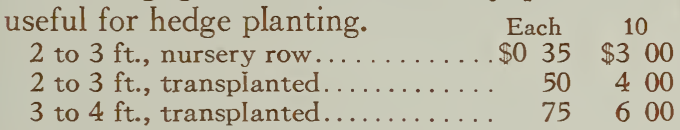

Privet, Ibota (Ligustrum Ibota). Reputed as being the hardiest of all Privets. A good hedge plant. Foliage turns a dark red in autumn.

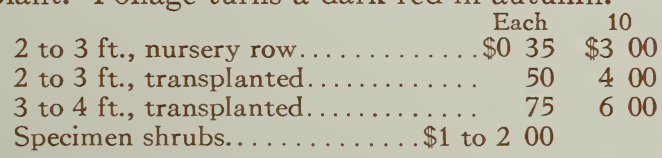

Pyrus arbutifolia (Choke Cherry). A tallgrowing shrub with clusters of small white flowers followed in August by bright red berries that hang until winter. Bright crimson autumn foliage.

Each 10

2 to $3 \mathrm{ft}$., nursery row...........\$0 $35 \$ 300$

2 to $3 \mathrm{ft}$., transplanted............. $50 \quad 400$

3 to $4 \mathrm{ft}$., transplanted............ $75 \quad 600$

Specimen shrubs........\$1.50 to 400

Siberian Pea Tree (Caragana arborescens). Bright green foliage and numerous small clusters of bright yellow flowers. Each 10

18 to 24 in., nursery row.........\$0 25 $\$ 200$

2 to $3 \mathrm{ft}$, nursery row.......... $35 \quad 300$

2 to $3 \mathrm{ft}$., transplanted.......... $50 \quad 400$

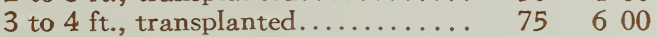

4 to $5 \mathrm{ft}$., transplanted........... $100 \quad 800$

Specimen shrubs........\$1.50 to 500

Snowball, Carles' (Viburnum Carlesii). Of recent introduction from Korea, producing a delicate spice-scented flower in May and June. Buds are pink, changing to pure white, and last through the season.

2 to $3 \mathrm{ft}$., transplanted.......... \$1 $00 \$ 800$

3 to $4 \mathrm{ft}$., transplanted............ $150 \quad 1200$

Snowball, Common (Viburnum Opulus sterile).

Clusters of pure white flowers. Each 10

18 to 24 in., nursery row.........\$0 25 $\$ 200$

2 to $3 \mathrm{ft}$., nursery row.......... $35 \quad 300$

2 to $3 \mathrm{ft}$., transplanted........... $50 \quad 400$

3 to $4 \mathrm{ft}$., transplanted............ $75 \quad 600$

4 to $5 \mathrm{ft}$., transplanted........... $100 \quad 800$

Specimen shrubs.......\$1.50 to 500

Snowball, Tree or Standard. The same shrub trained into a plant with one stem. Each 10 4 to $5 \mathrm{ft}$., transplanted........... \$1 $00 \quad \$ 800$

Snowball, Arrow-wood (Viburnum dentatum). Glossy, handsome leaves; white flowers; fine steel-blue berries in fall.

2 to $3 \mathrm{ft}$., nursery row.......... $\$ 035 \quad \$ 300$

2 to $3 \mathrm{ft}$., transplanted............. $50 \quad 400$

3 to $4 \mathrm{ft}$., transplanted........... $75 \quad 600$

Specimen shrubs ..........\$1 to 300

Snowball, Wayfaring Tree (Viburnum Lantana). Red fruit turning black. Each 10

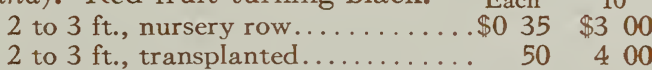

3 to $4 \mathrm{ft}$., transplanted........... $75 \quad 600$

Specimen shrubs ........\$1.50 to 500

Snowball, Lentage Sheepberry (Viburnum Lentago) A large-growing shrub; leaves bronze when young, glossy green in midsummer, and brilliant orange and red in autumn. Flowers creamy white, with dark blue berries in autumn on red stems.

Each 10

2 to $3 \mathrm{ft}$., nursery row.........\$0 $35 \quad \$ 300$

2 to $3 \mathrm{ft}$., transplanted........... $50 \quad 400$

3 to $4 \mathrm{ft}$., transplanted............ $75 \quad 600$ 


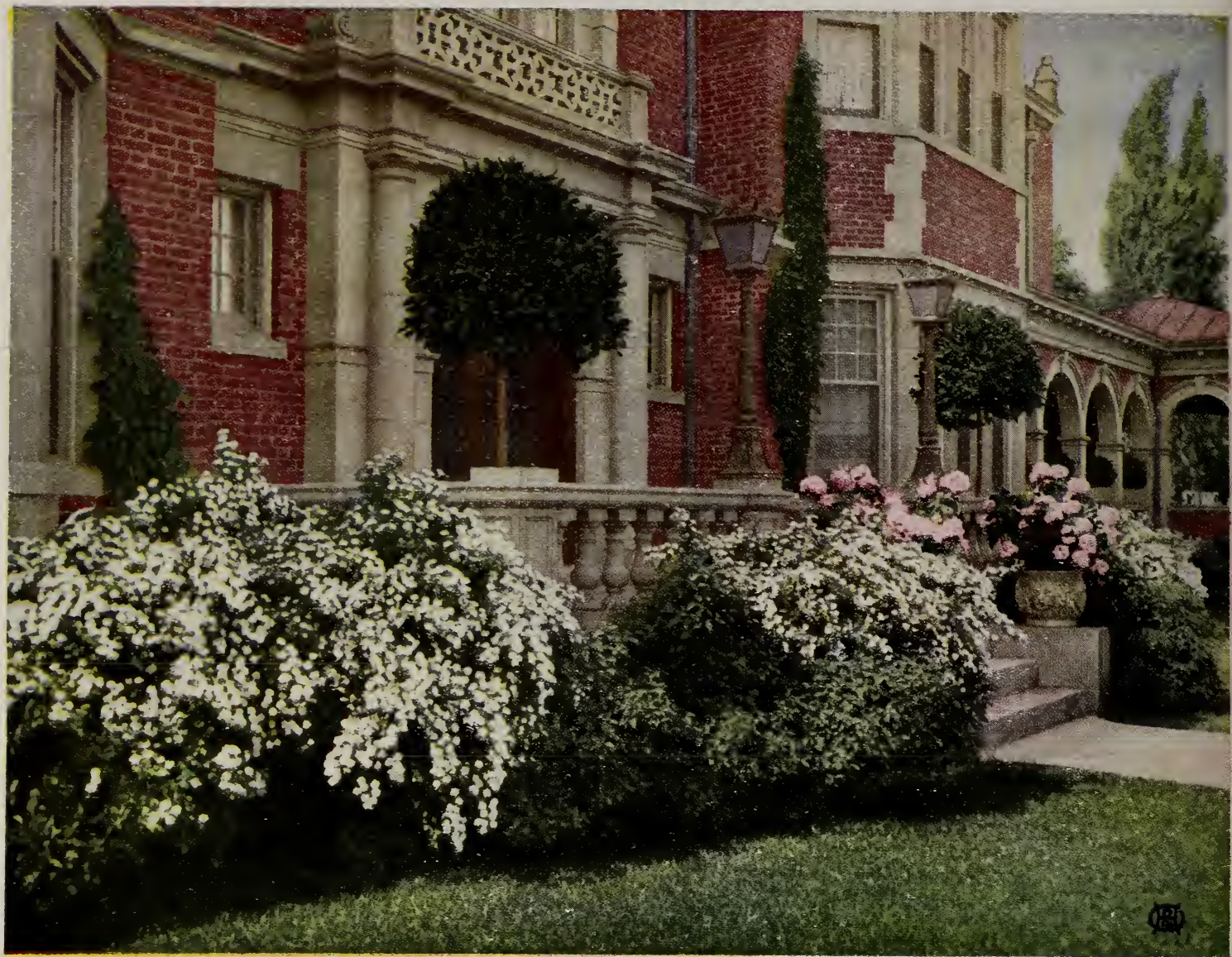

A picturesque planting all the year. The gray trimmings of the bouse seem to make the white flowers of the Spireas even whiter; the Bay trees and Engelmann's Ivy furnish the needed beight for the planting

\section{DECIDUOUS SHRUBS, continued}

Snowball, High-bush Cranberry (Viburnum Opulus). One of the best.

18 to 24 in., nursery row......... \$0 25 \$2 00

2 to $3 \mathrm{ft}$., nursery row............ $35 \quad 300$

2 to $3 \mathrm{ft}$., transplanted.............. $50 \quad 400$

3 to $4 \mathrm{ft}$., transplanted........... $75 \quad 600$

4 to $5 \mathrm{ft}$., transplanted................ $100 \quad 800$

Specimen shrubs........\$1.50 to 500

Snowball, High-bush Cranberry (Viburnum Opulus), American Type. Quite different from the regular type; leaves glossy green with red stems, and are free from insects. Each 10

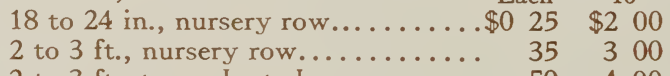

2 to $3 \mathrm{ft}$., transplanted......... $50 \quad 400$

3 to $4 \mathrm{ft}$., transplanted............... $75 \quad 600$

4 to $5 \mathrm{ft}$., transplanted............ $100 \quad 800$

Specimen shrubs........\$1.50 to 500

Snowball, Dwarf Cranberry (Viburnum Opulus nanum). Very hardy, and, in the colder climates where boxwood cannot be depended upon, will answer the same purpose. Each 10

10 to 12 in., transplanted......... \$0 $50 \$ 400$ 12 to 15 in., transplanted.......... $75 \quad 600$

Snowball, Japanese (Viburnum tomentosum plicatum). Flowers pure white, borne along the branch in flat cymes.

2 to $3 \mathrm{ft}$., nursery row.......... \$0 $35 \$ 300$

2 to $3 \mathrm{ft}$., transplanted................ 50 400

3 to $4 \mathrm{ft}$., transplanted............ $75 \quad 600$
Snowberry, Red, or Indian Currant (Symphoricarpos vulgaris). Red-fruited. The berries are reddish purple and hang all winter.

18 to 24 in., nursery row.......... Each $\$ 25 \quad \$ 200$

2 to $3 \mathrm{ft}$., nursery row............. $35 \quad 300$

2 to $3 \mathrm{ft}$., transplanted............... $50 \quad 400$

3 to $4 \mathrm{ft}$., transplanted............. $75 \quad 600$

Specimen shrubs..........\$1 to 350

Snowberry, White (Symphoricarpos racemosus). Small pink flowers, and large white berries which are produced in great quantities.

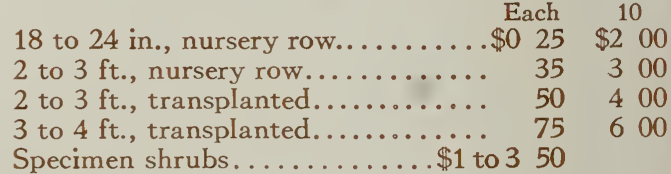

Snowberry, Variegated (Symphoricarpos variegatus). Yellow and green leaves. Each 10 18 to 24 in., transplanted..........\$0 $50 \$ 400$ 2 to $3 \mathrm{ft}$., transplanted............ $75 \quad 600$

Spiræa, Anthony Waterer. Dwarf. Bears flat heads of brilliant rosy blossoms all through the latter part of the summer; an exceedingly free-blooming variety.

Each 10 12 to 18 in., nursery row......... \$0 25 $\$ 200$ 18 to 24 in., nursery row......... $35 \quad 300$ 18 to 24 in., transplanted........ $50 \quad 400$ Specimen shrubs .........\$1 to 200 


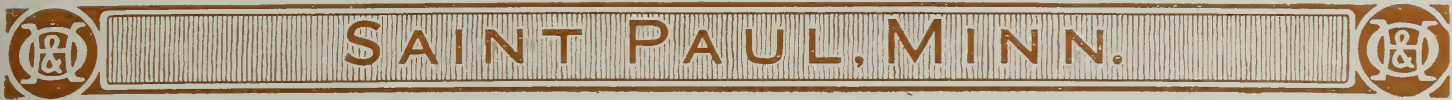

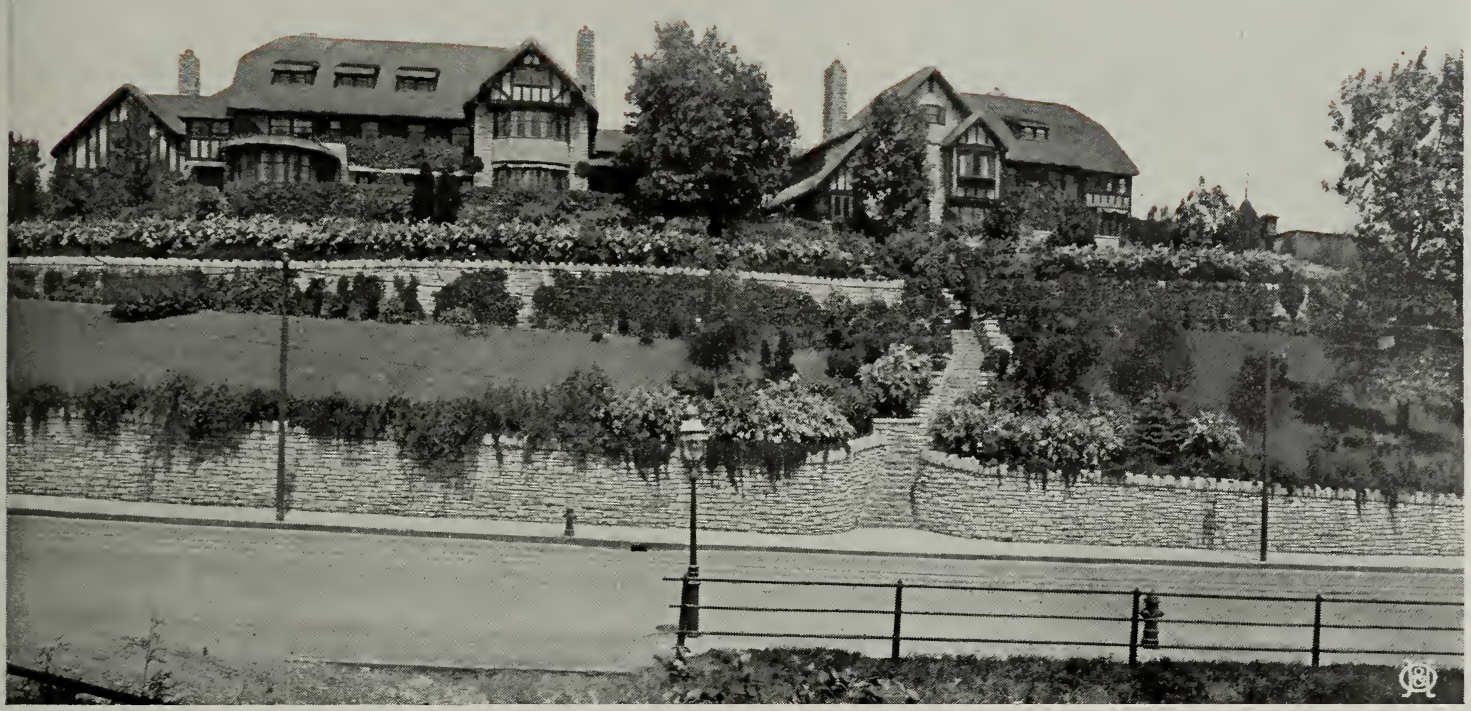

Small shrubs and vines were planted bere five years ago. Notice the wonderful development

\section{DECIDUOUS SHRUBS, continued}

Spiræa arguta. Large flowers borne on comparatively upright stems. One of the best Spireas.

2 to $3 \mathrm{ft}$., nursery row.......... \$0 $35 \$ \$ 300$

2 to $3 \mathrm{ft}$., transplanted.............. $50 \quad 400$

3 to $4 \mathrm{ft}$., transplanted........... $75 \quad 600$

Specimen shrubs..........\$1 to 200

Spiræa aurea (Golden Spirea). One of the best of our yellow-leaved shrubs. Holds its color all summer.

2 to $3 \mathrm{ft}$., nursery row.......... $\$ 035 \$ 300$

2 to $3 \mathrm{ft}$., transplanted............... $50 \quad 400$

3 to $4 \mathrm{ft}$., transplanted............ $75 \quad 600$

4 to $5 \mathrm{ft}$., transplanted........... $100 \quad 800$

Specimen shrubs .......\$1.50 to 350

Spiræa Billiardii. Narrow, dense spikes of bright pink flowers. A strong grower; useful in shrubberies.

2 to $3 \mathrm{ft}$., nursery row............ \$0 $35 \quad \$ 300$

2 to $3 \mathrm{ft}$., transplanted................ $50 \quad 400$

3 to $4 \mathrm{ft}$., transplanted............. $75 \quad 600$

4 to $5 \mathrm{ft}$., transplanted........... $100 \quad 800$

Specimen shrubs........\$1.50 to 250

Spiræa Bumalda. Dwarf. Showy, rose-colored flowers all summer. One of the best for growing in front of tall shrubs.

12 to 18 in nursery row ........ Each 10

18 to 24 in., nursery row......... $35 \quad 300$

18 to 24 in., transplanted....... $50 \quad 400$

Specimen shrubs ..........\$1 to 200

Spiræa callosa alba. Dwarf. Pure white; one of the best dwarfs; blooms all summer; can be planted as a margin to the shrubbery border, or as a single specimen.

10 to 12 in., nursery row.

12 to 18 in., transplanted.

18 to 24 in., transplanted.

Specimen shrubs

Each 10

\$0 $25 \quad \$ 200$

$50 \quad 400$

$\$ 1$ to 200
Spiræa callosa rubra. Deep rose-red flowers in close clusters, nearly all summer.

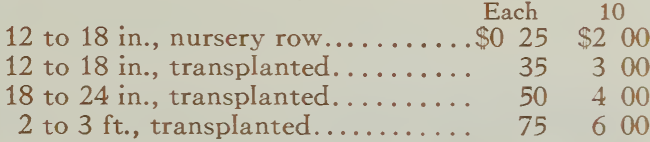

Spiræa Douglasii. A Iow-growing shrub, with deep rose-colored flowers.

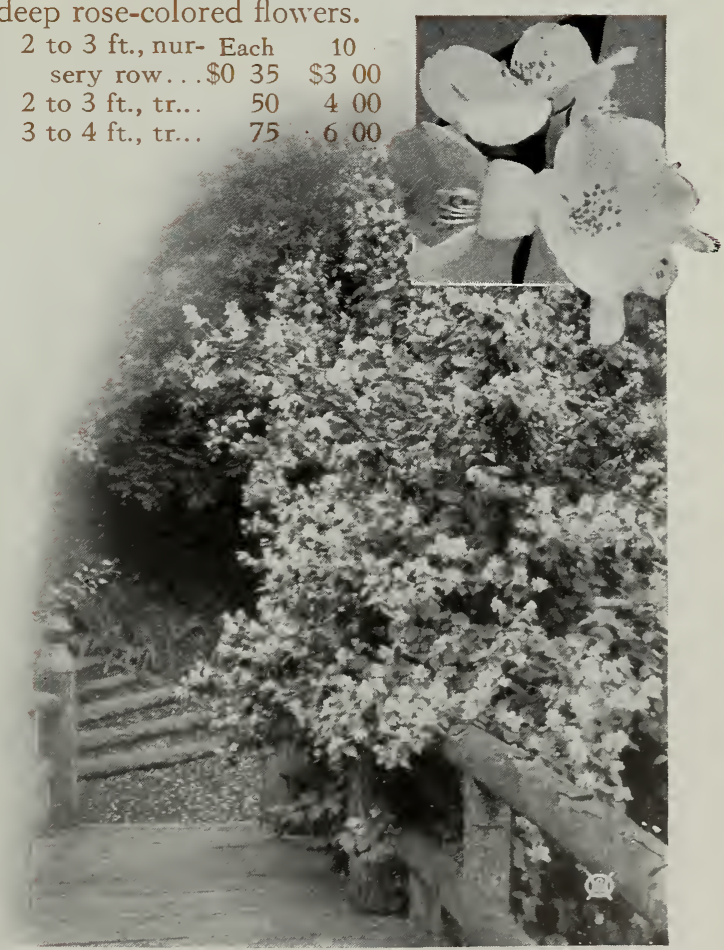

Plant and balf-sized bloom of Syringa (see page 39) 


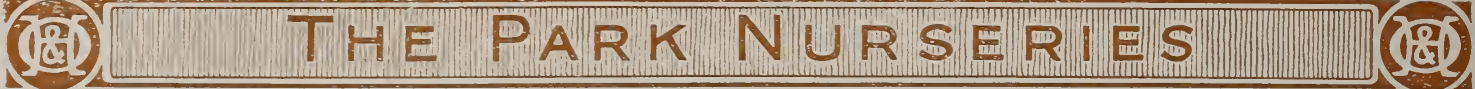

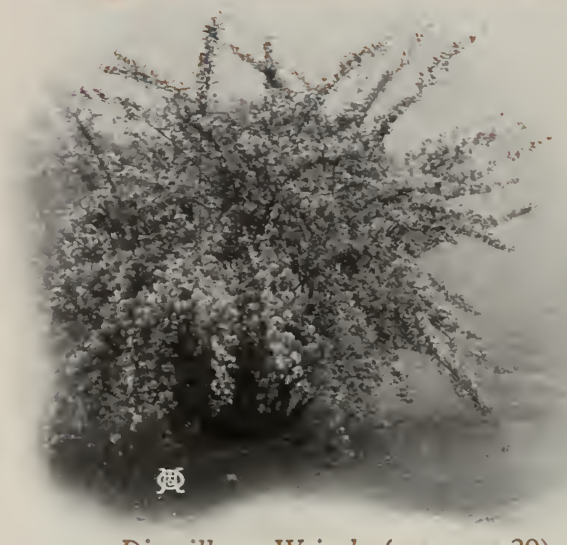

Diervilla or Weigela (see page 39)

\section{DECIDUOUS SHRUBS, continued}

Spiræa opulifolia. It grows rapidly upright, to 10 feet, aIthough its branches droop when laden with white flowers.

\begin{tabular}{|c|c|c|}
\hline 2 to $3 \mathrm{ft}$., nur- Eac & $\$ 33^{10}$ & 4 to $5 \mathrm{ft}$ trons \\
\hline sery row.....\$0 3 & $\$ 300$ & 4 to $5 \mathrm{ft}$., trans... \\
\hline $\begin{array}{l}2 \text { to } 3 \mathrm{ft} \text {., trans. } \\
3 \text { to } 4 \mathrm{ft} \text {., trans. }\end{array}$ & $\begin{array}{l}400 \\
600\end{array}$ & $\begin{array}{l}\text { cimen shrubs.... } \\
\$ 1.50 \text { to } 250\end{array}$ \\
\hline
\end{tabular}

Spiræa prunifolia. As the leaves are opening, small, snowwhite, double flowers wrap themselves along the branches in a lavish display of bloom.

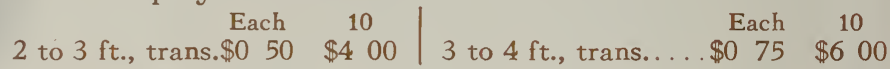

Spiræa Reevesii. Round clusters of white flowers. A charming shrub. Each $10 \quad$ Each 10 18 to 24 in., nur. row.\$0 $25 \$ 200 \mid 2$ to $3 \mathrm{ft}$., trans.... \$0 50 \$4 00 2 to $3 \mathrm{ft}$., nursery row.. $35300 \quad 3$ to $4 \mathrm{ft}$., trans.... $75 \quad 700$

Spiræa Reevesii flore pleno. An equally fine, Prices of Spiræa Thunbergii 18 to 24 in., nursery row. double form of the former.

18 to 24 in., nursery row.

2 to $3 \mathrm{ft}$., nursery row.

2 to $3 \mathrm{ft}$., transplanted

3 to $4 \mathrm{ft}$., transplanted

Each 10

$\$ 0 \quad 25 \$ 200$

35300

$50 \quad 400$

75600

Spiræa sorbifolia. Long, showy panicles of white flowers. A fine Spirea.

18 to 24 in., nursery row.

2 to $3 \mathrm{ft}$., nursery row

2 to $3 \mathrm{ft}$., transplanted.

3 to $4 \mathrm{ft}$., transplanted

Specimen shrubs

$\$ 1$ to 250

$\begin{array}{rrr}\text { Each } & 10 \\ \$ 025 & \$ 200 \\ 35 & 300 \\ 50 & 400 \\ 75 & 600\end{array}$

Spiræa Thunbergii. Low-growing, rounded. Abundant small white flowers in May.

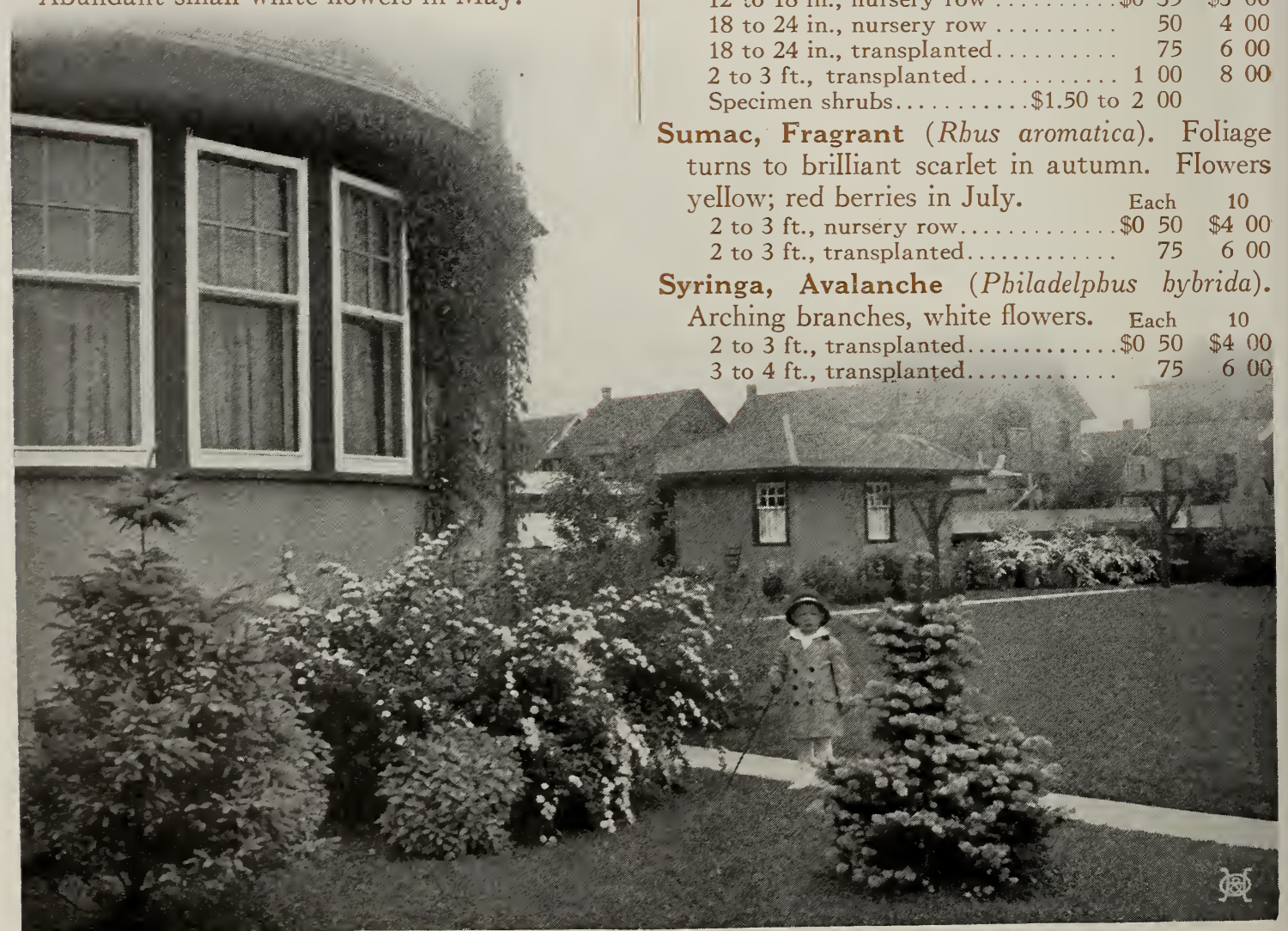

18 to 24 in., transplanted. ........... $50 \$ 700$ 2 to $3 \mathrm{ft}$., transplanted........... $75 \quad 600$

Spirza Van Houttei (Bridal Wreath). Pure white flowers in clusters.

18 to 24 in., nursery row.

2 to $3 \mathrm{ft}$. nursery row.

2 to $3 \mathrm{ft}$., transplanted.

3 to $4 \mathrm{ft}$., transplanted.

4 to $5 \mathrm{ft}$., transplanted.

Specimen shrubs ...

Each 10

$35 \quad 300$

$\begin{array}{lll}50 & 4 & 00\end{array}$

$\begin{array}{lll}75 & 600\end{array}$

$100 \quad 800$

Sumac, Cut-leaved (Rbus glabra laciniata). Fern-like leaves, dark green above, glaucous beneath; rich red in autumn.

12 to 18 in., nursery row

18 to 24 in., nursery row

18 to 24 in., transplanted.

2 to $3 \mathrm{ft}$., transplanted.

umac, Fragrant (Rbus aromatica). Foliage turns to brilliant scarlet in autumn. Flowers ellow; red berries in July.

2 to $3 \mathrm{ft}$., nursery row...

Each 10

$035 \$ 300$

400

00

更 
DECIDUOUS SHRUBS, continued

Syringa, Golden Dwarf (Pbiladelpbus aureus). that remains bright through the season.

10 to 12 in., nursery row

12 to 18 in., nursery row

12 to 18 in., transplanted.

18 to 24 in., transplanted.

Syringa grandiflora (Pbiladelphus grandiflorus).

flowers in June. Each 10

2 to $3 \mathrm{ft}$., nursery

row.......

$\$ 035$

10

3 to $4 \mathrm{ft} .$, trans.
4 to $5 \mathrm{ft}$. , trans.
Spec.

$50 \quad 400$

Spec. shrubs.

2 to $3 \mathrm{ft}$, trans..

\section{(Philadelphus L}

fine; semi-double; fragrant; June.

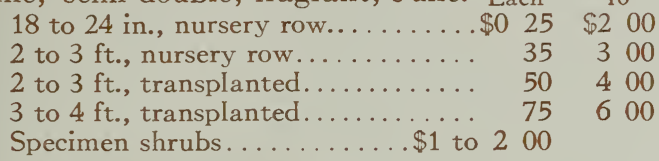

Specimen shrubs.

\$1 to 200

Syringa, Mock Orange (Pbiladelphus coronarius). Its Iarge, showy white flowers are delightfully scented.

2 to $3 \mathrm{ft}$., nursery row

2 to $3 \mathrm{ft}$., transplanted.

3 to $4 \mathrm{ft}$., transplanted.

4 to $5 \mathrm{ft}$., transplanted.

Specimen shrubs.

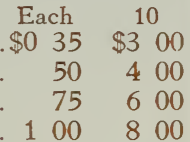

Syringa, Mont Blanc (Pbiladelphus Mont Blanc). Choice and distinct flowers, large and fragrant. Bush medium size.

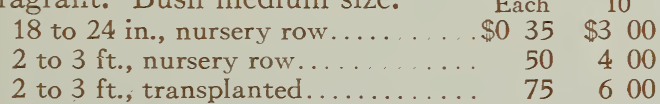

Tamarix Odessana. Longer racemes of flowers.

2 to $3 \mathrm{ft}$., nursery row

2 to $3 \mathrm{ft}$., transplanted.

3 to $4 \mathrm{ft}$., transplanted.

Specimen shrubs.

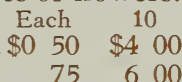

$100 \quad 800$

Tamarix hispida æstivalis. Blooms when few other shrubs are in flower, and its feathery, delicate, soft pink sprays of blossoms are exceedingly attractive.

2 to $3 \mathrm{ft}$., nursery row

2 to $3 \mathrm{ft}$., transplanted.

3 to $4 \mathrm{ft}$., transplanted.

Specimen shrubs.

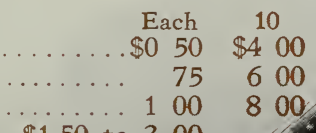

$\$ 1.50$ to 300

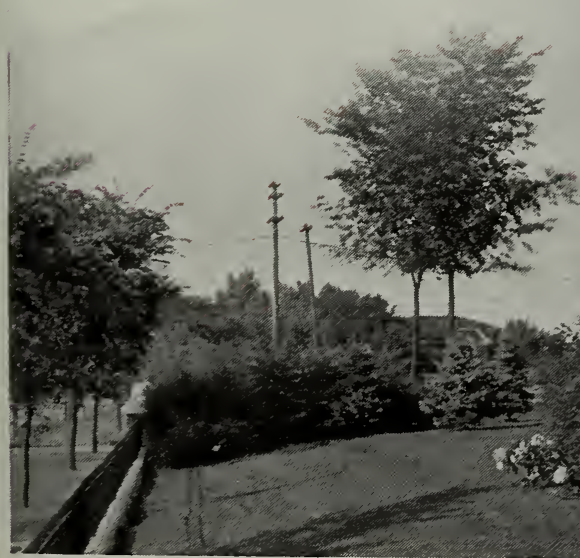

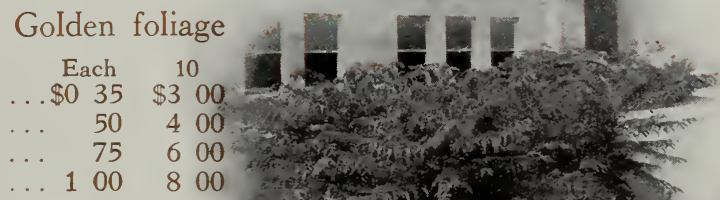

Fragrar

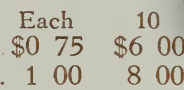

Flowers large and

Cut-leaved Sumac (see page 38)

Weigela Desboisii (Diervilla bybrida). Deep

rose-colored flowers borne freely. Each 10

18 to 24 in., nursery row.........\$0 $25 \$ \$ 200$

2 to $3 \mathrm{ft}$., nursery row.......... $35 \quad 300$

2 to $3 \mathrm{ft}$., transplanted............ $50 \quad 400$

3 to $4 \mathrm{ft}$., transplanted..................... $75 \quad 600$

Specimen shrubs .........\$1 to 250

Weigela, Eva Rathke (Diervilla bybrida). Free bloomer; brilliant crimson.
18 to 24 in., nursery row.
2 to $3 \mathrm{ft}$., transplanted.
3 to $4 \mathrm{ft}$., transplanted.
$\$ 035 \$ 300$
$\begin{array}{lll}50 & 4 & 00\end{array}$
75600

Each 10

Specimen shrubs

Weigela rosea (Diervilla rosea). Flowers pink,

rose and white; May and June. Each 10

18 to 24 in., nursery row

$\$ 0 \begin{array}{lll}\$ 0 & 25 & \$ 200\end{array}$

2 to $3 \mathrm{ft}$., nursery row.

2 to $3 \mathrm{ft}$., transplanted.

3 to $4 \mathrm{ft}$., transplanted

Specimen shrubs.

35300

400

75600

Weigela rosea nana variegata. Silvery varicgated leaves and pale pink flowers. Each 10

18 to 24 in., nursery row......... $\$ 025 \quad \$ 200$

2 to $3 \mathrm{ft}$., nursery row......... $35 \quad 300$

2 to $3 \mathrm{ft}$., transplanted........... $50 \quad 400$

3 to $4 \mathrm{ft}$., transplanted............ $75 \quad 600$

Specimen shrubs ............ \$1 to 250

00
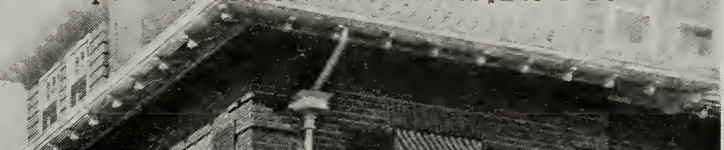

1.
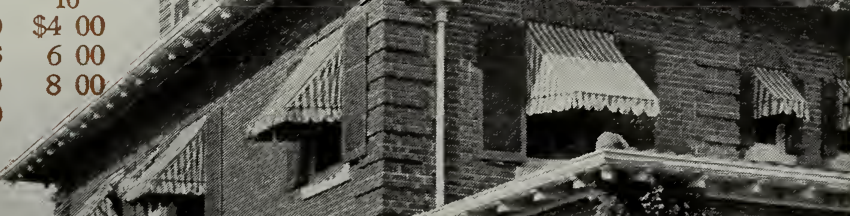

cting
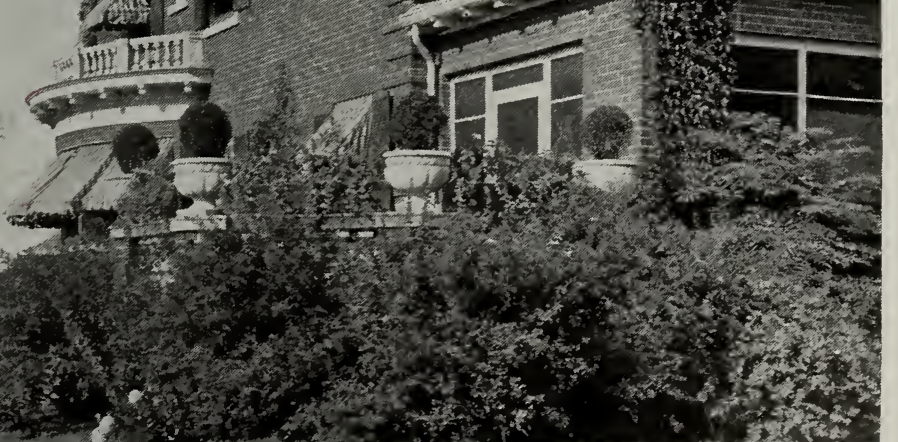

A pleasing effect secured in tbree years, by using a few specimen shrubs 


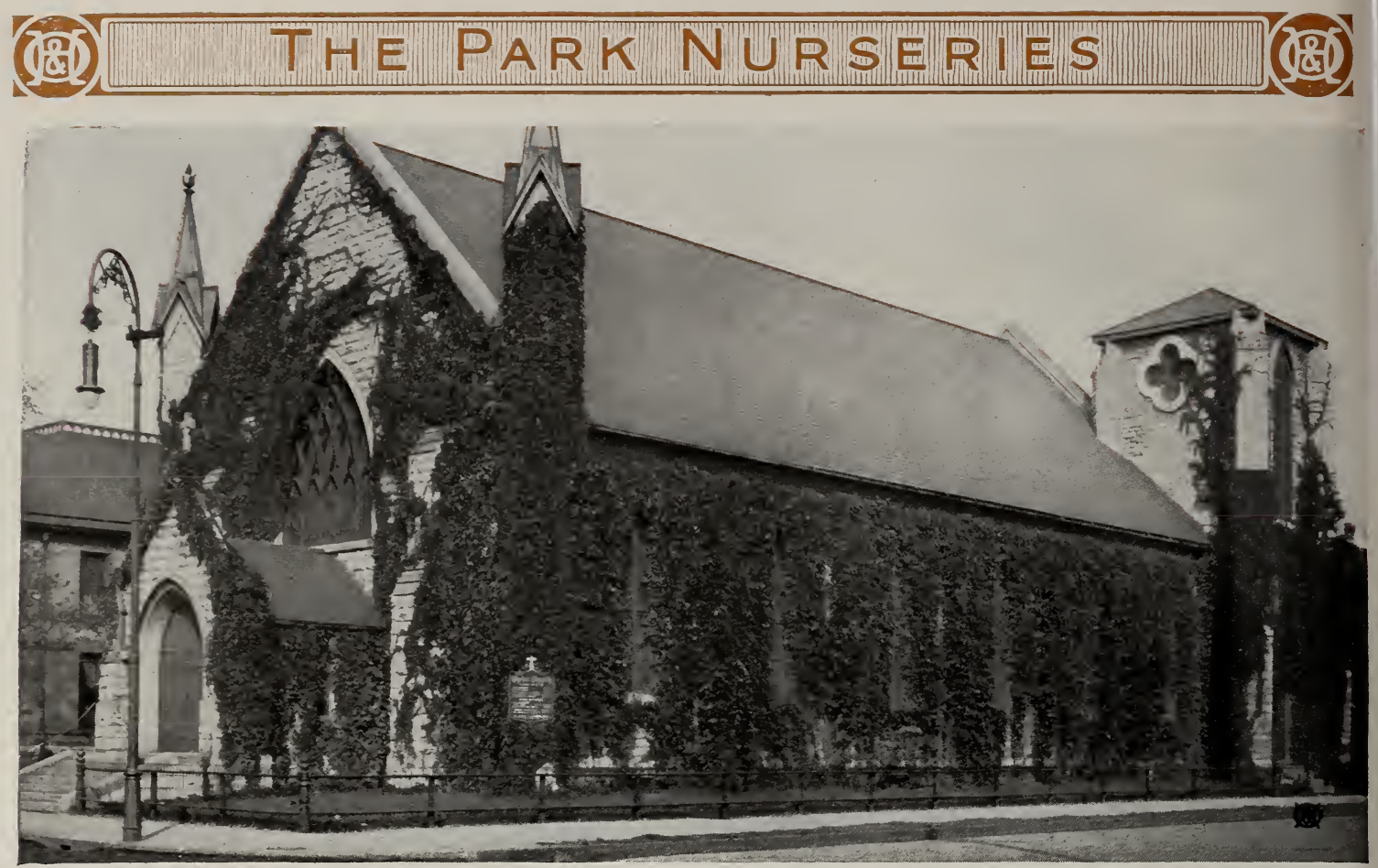

Cbrist Cburch, one of St. Paul's landmarks, is almost bidden by the luxuriant growth of Ampelopsis Engelmanni

\section{CLIMBING VINES AND CREEPERS}

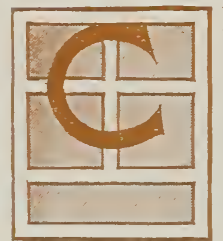

LIMBING VINES are just as necessary in the beautifying of grounds as shrubs, trees or grass; they have their important part in the planting of every place.

Around new buildings, they give shade quickly and are very cooling and cheerful. For verandas or trellises, there is nothing that adds more beauty than a proper selection of vines, and, by covering summer-houses, or trunks of dead trees, a strikingIy wild, naturalistic effect is secured.

Vines are often used for covering stone walls, rocky banks and steep slopes, where not only are they attractive, but the fragrance from the flowers is very pleasing. Certain species of vines are adapted for clinging to brick and stone walls, and thus tone down their rough effect and soften the lines of architecture. Innumerable uses for vines will suggest themselves when improving a property. The ideas given here are practical and tried. Perhaps we can help you.

Ampelopsis Engelmanni (Engelmann's Ivy). A type

of the Virginia Creeper, but different in growth as

well as foliage. It has much shorter joints, and very

much smaller and thicker foliage. This

is the only Ampelopsis that is perfectly

hardy in Minnesota, and that will cling

to brick, stone or plaster. It is

equipped with sufficient tendrils by

which it clings to walls to hold it

very close and firm. This variety is

a rapid grower, has a beautiful dark green foliage, and in the fall has a beautiful autumn effect, the leaves changing to almost crimson. It is used to great advantage on churches and Iarge buildings of all kinds, to break the hard stone and brick effects.

2 yrs., nursery row.

2 yrs., transplanted.

3 yrs., transplanted. ..... 75
Extra-strong plants. $\$ 1$ to 150

Each
$\$ 035$

$\$ 300$

400

600

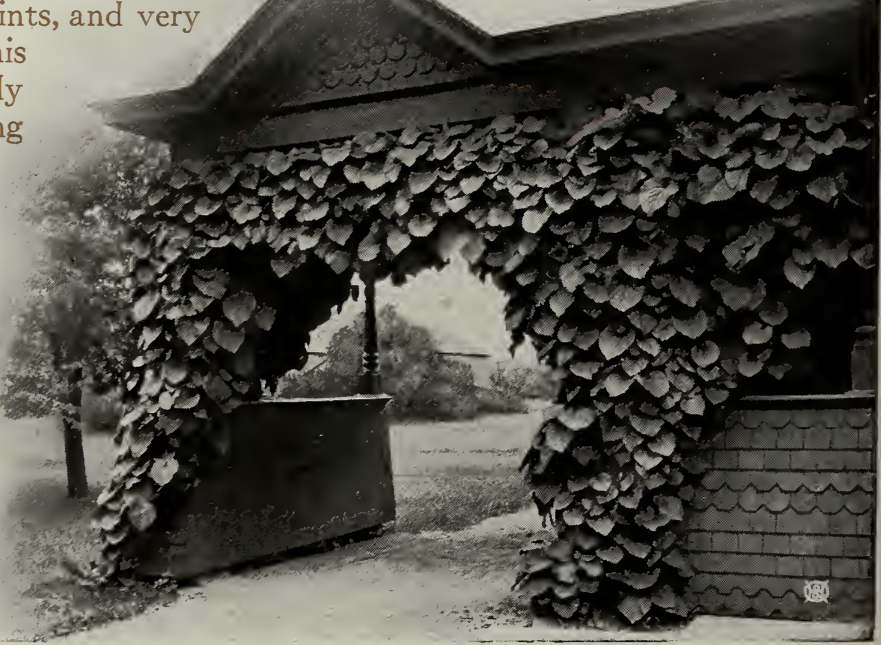

The Dutcbman's Pipe is bardy, a rapid grower, witb few equals as a porcb screen (see page 43 ) 


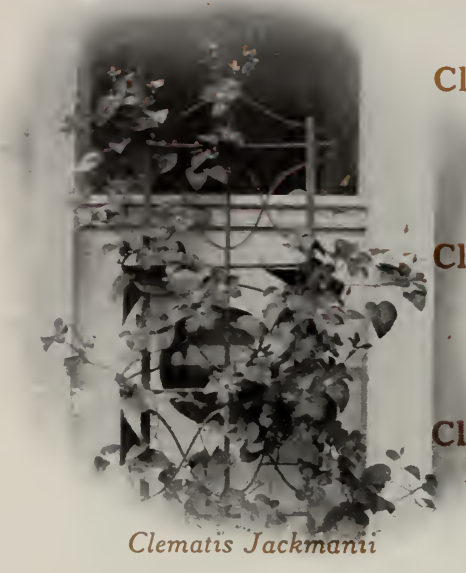

CLIMBING VINES AND CREEPERS, continued

Clematis coccinea (Scarlet Clematis). A very handsome, hardy climber, bearing thick, bell-shaped flowers of bright coral-red. Blooms with wonderful profusion from June until frost. 2 yrs., strong Each 10 3 yrs., strong $\$ 0 \quad 50 \$ 400$ (and and Jackmanii are grown together, the contrast of the large white and blue flowers makes a brilliant and charming effect. 3 yrs., strong.

Each 10 Potted plants

$17 \$ 600$

Clematis Henryi. Creamy white; Iarge and of fine shape; a free grower and bloomer. One of the finest of the large-flowered Clematis. The foliage is very handsome and sets off the white flowers beautifully. Each 10 3 yrs., strong. .
Potted plants.

$\$ 075 \$ 600$

Clematis Jackmanii. Flowers, when fully expanded, are 4 to 6 inches in diameter, intense violet-purple, with a rich, velvety appearance, distinctly veined. It blooms continually from July until cut off by frost. 3 yrs., strong. Each 10 Potted plants. $\$ 075 \$ 600$ $100 \quad 800$

Clematis, Madame Edouard Andre. Has been called the Crimson Jackmanii. The plant is a strong, vigorous grower, and very free in bloom. Color a distinct crimson-red. Entirely distinct from all other varieties. Each 10 3 yrs., strong..............\$0 75 \$6 00 Potted plants. 100800

Clematis montana rubens. This beautifuI, hardy, new Clematis begins to bloom early in June, when a profusion of soft rosy red blooms, resembling those of the Japanese anemone, are produced As the flowers are borne on the young wood, they appear more or less freely until frost. A First-class Certificate was awarded to this plant by the Royal Horticultural Society of London.

3 yrs., strong.

Potted plants.

Each 10

$\$ 075 \$ \$ 600$ $100 \quad 800$

Clematis paniculata. Of very rapid growth, quickly covering trellises and arbors with handsome, clean, glossy foliage. The flowers are of medium size, fragrant, pure white, borne in immense sheets in September, when very few other vines are in bloom.

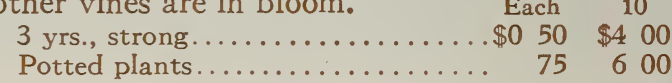

Clematis, Ramona. A strong, rampant grower and a true perpetual bloomer, flowers appearing on the last year's growth and on the new shoots, giving an abundance of bloom aII through the season. Color deep, rich Iavender.

$$
\begin{aligned}
& \text { Each } 10 \\
& 3 \text { yrs., strong............... \$0 75 \$6 } 00 \\
& \text { Potted plants.................. } 100 \quad 800
\end{aligned}
$$

Clematis Virginiana. One of the most rapid growers, producing quantities of greenish white flowers, succeeded by brown, hair-like seed-plumes.

3 yrs., strong. Each 10 Potted plants $\$ 0 \quad 50 \$ 400$

The proper placing of trees and otber growing tbings about the bome is an art in itself, and the "H. eo O. Service" stands ready to advise just what and bow to plant. Tbis service is at your disposal, for we want our patrons to get all the possible joy of their garden and otber plantings. Send us an idea of your requirements, and we will be glad to belp you, supplying complete plans.

A beautiful effect obtained with Clematis paniculata 
CLIMBING VINES AND CREEPERS, continued

Dutchman's Pipe (Aristolocbia Sipho). A magnificent hardy vine of rapid growth, with very large, heart-shaped leaves and brownish flowers, resembling in shape a miniature pipe. Splendid for archways or verandas, as it is a very rapid grower and forms a dense, cool shade on the hottest summer days.

$$
2 \text { yrs., strong. }
$$

3 yrs., strong.

Honeysuckle, Hall's Japan (Lonicera Halliana). More generally used than any other variety. Deep green foliage, which is almost evergreen through the winter, the fragrant yellow and white flowers blooming until frost. Its flowers are much beloved by humming-birds, which can be seen hovering over them all summer.

$$
\begin{aligned}
& 2 \text { yrs., strong, transplanted... } \\
& 3 \text { yrs., strong, transplanted... }
\end{aligned}
$$

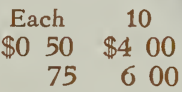

Honeysuckle, Scarlet Trumpet. (Lonicera sempervirens). This bears during the summer clusters of scarlet, tubular flowers, and is one of the freest and best varieties. Handsome in foliage and fruit.

2 yrs., strong, transplanted.

Each 10

3 yrs., strong, transplanted.

$\$ 050 \$ 400$

75600

Matrimony Vine (Lycium Chinense). A hardy plant that serves as a vine or shrub. Slender; drooping branches. Bears pink and purpleflowers, from June until September, that are succeeded in winter by scarlet and orange fruits. The illustration shows the treatment of festooning a stone waIl, which is very pleasing, besides breaking the hard lines of the wall. See page 41 .

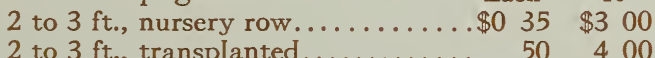

2 to $3 \mathrm{ft}$., transplanted........... $50 \quad 400$

3 to $4 \mathrm{ft}$., transplanted.

75600

Vitis, or Hardy Wild Grape. A strong, rapidclimbing vine, with large, thick leaves; berries are large, purplish black to reddish brown, with musky flavor.

2 yrs., strong, transplanted......... $\$ 0 \quad 50 \quad \begin{array}{llll}\text { Each } & 00\end{array}$

3 yrs., strong, transplanted......... $75 \quad 600$

Specimen plants...........\$1 to 200 flowers.$$
\begin{array}{cc}
\text { Each } & 10 \\
\$ 075 & \$ 600
\end{array}
$$

$100 \quad 800$

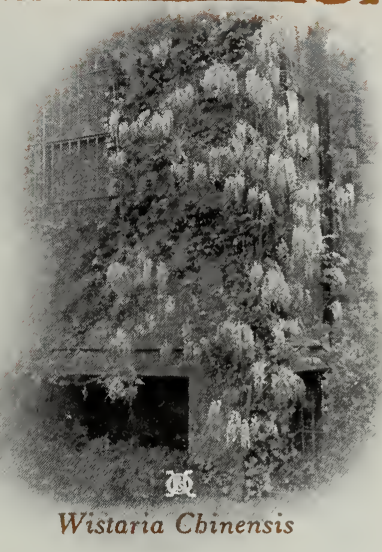

Vitis, Beta (Grape). The fruit is of as good quality as the Janesville. Northern nurserymen are offering it as a fruiting Grape for exposed locations, but as it is a vigorous climber and with good foliage, it is also a valuable addition to the ornamental list. . Each 10 2 yrs., strong, transplanted.......\$0 75 \$6 00 3 yrs., strong, transplanted......... $100 \quad 800$ Specimen plants........\$1.50 to 200

Wistaria Chinensis (Chinese Purple Wistaria). May and August. The most popular Wistaria. Pale blue flowers in pendulous clusters. AII the Wistarias are fine for growing as an embellishment to a second-story porch, as they are aII high climbers. Each 10 2 yrs., strong, transplanted........ \$0 $75 \$ \$ 600$ 3 yrs., strong, transplanted........... $100 \quad 800$

Wistaria Chinensis alba (Chinese White Wistaria). White-flowered variety of the former. 2 yrs., strong, transplanted........ $\$ 100 \quad$\begin{tabular}{cc} 
Each & 10 \\
\hline 8 & 00
\end{tabular} 3 yrs., strong, transplanted......... $150 \quad 12 \quad 50$

Wistaria frutescens (American Wistaria). An American variety. Not so free as the Chinese form, but a rapid grower. Fragrant, pale blue

2 yrs., strong, transplanted........\$0 50 \$4 00 3 yrs., strong, transplanted........ $75 \quad 600$

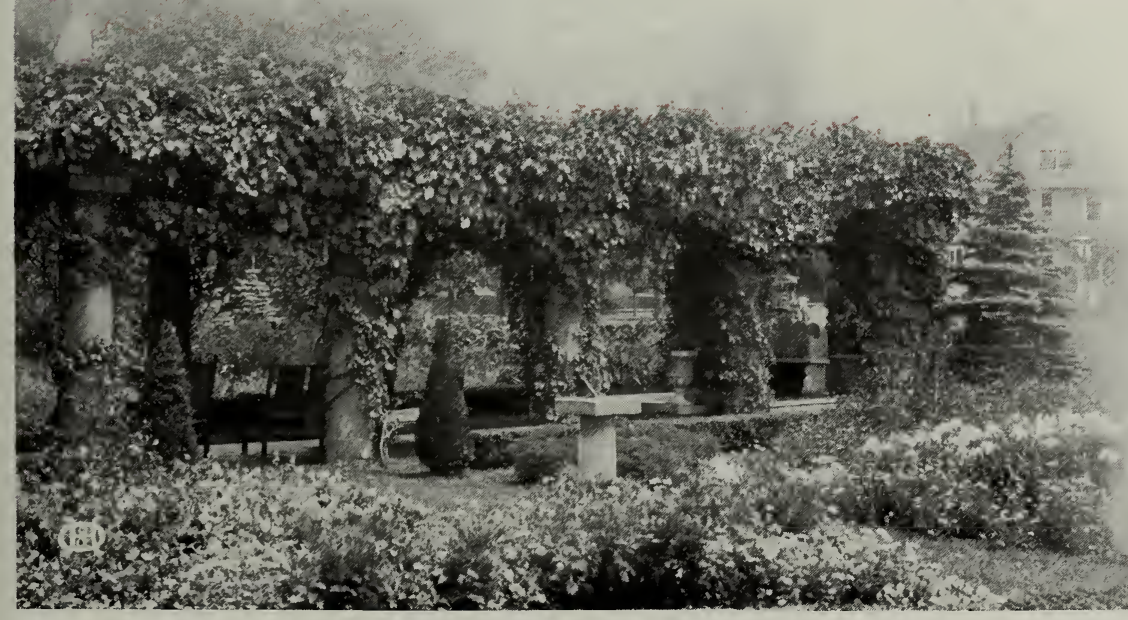

Combining beauty and utility-the pergola supports a number of Beta Grapevines
The largest assortment of specimen trees, sbrubs and vines to be bad in the country. Note from the illustrations bow they are grown. Eacb a specimen representing "H. \& O. Quality." These are admirably adapted to producing immediate effects about the bome, and will at once convert an otherwise barren spot into a place of beauty, witbout waiting for the slow processes of nature. 


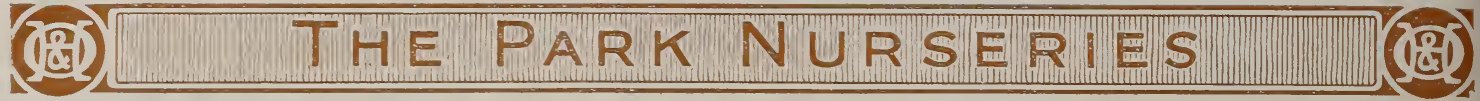

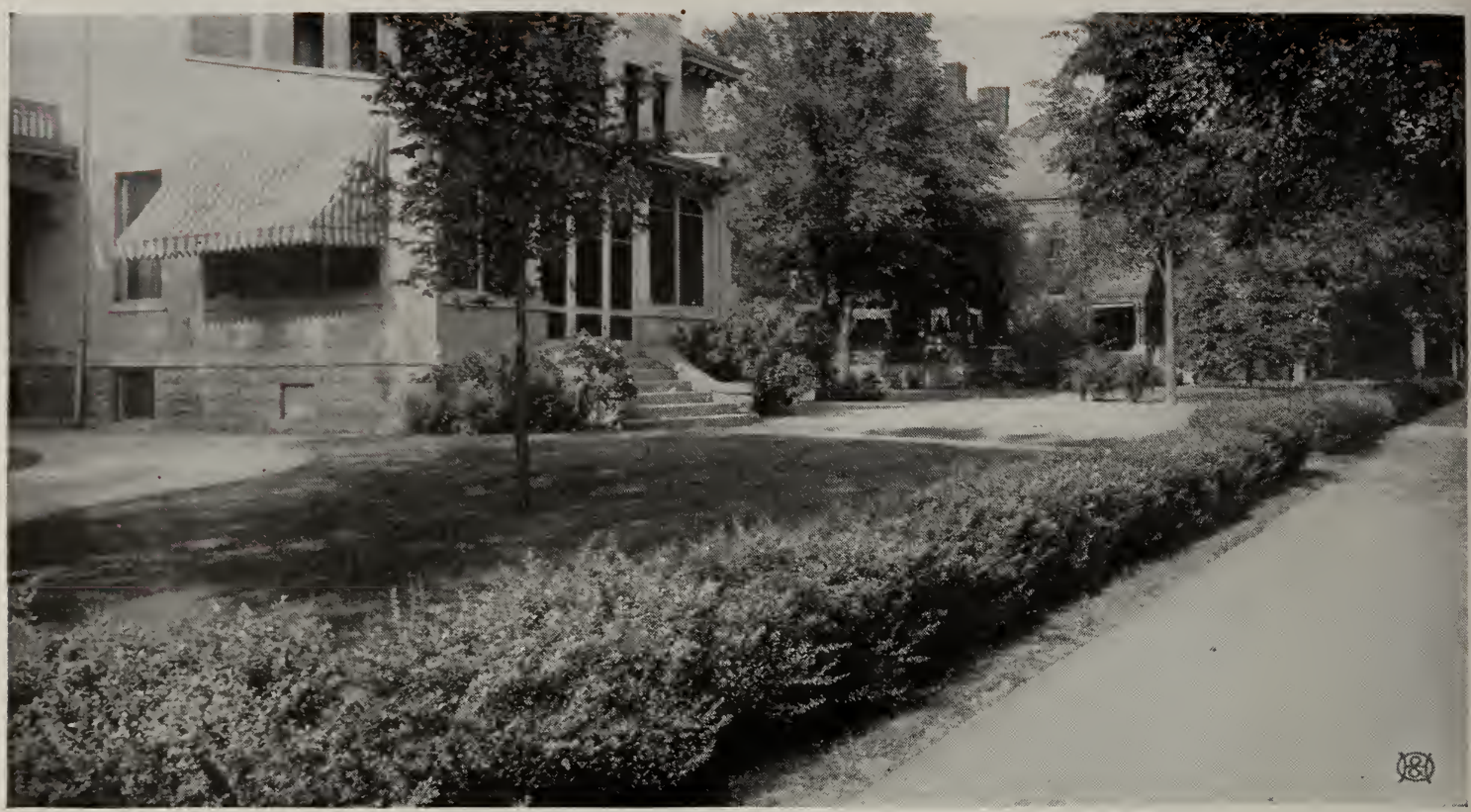

Tbunberg's Barberry makes a splendid low bedge for the street line. It grows quite dense, and offers considerable resistance to intruders. The red berries in winter are pleasing and attractive

\section{DECIDUOUS HEDGES}

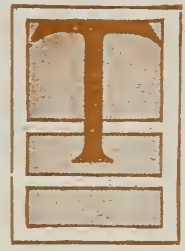

HERE is nothing quite so effective for the boundaries of a Iawn or property division as a hedge. It does not decay, nor does it require paint, but grows more beautiful and effective each year. The first cost of installing a hedge is its only cost, so that, from an economical standpoint, it is less expensive than a fence.

When a hedge is desired for screening, high-growing varieties should be used that do not require trimming; but when it is to act as a border or division, use shrubs of low, dense-growing habit.

We recommend Buckthorn as being the best for the Northwest, with compact, dense growth and dark green foliage. Where a formal effect is wanted, this can be trimmed in any manner desiredrounded or flat on top, with square sides. It is very hardy, withstanding our severe winters.

When a low hedge is wanted, we recommend Thunberg's Barberry - this is one of the most attractive and ornamental hedges there is. It is much admired for its beautiful foliage, compact growth, and red berries in the fall. Shrubs.

For fuller descriptions, see under Deciduous

Barberry, Green (Berberis vulgaris). Flowers yellow; berries dark red. Grows upright, 5 to 8 feet high, with light green foliage.

18 to 24 in., nursery row...... $\$ 200$
18 to 24 in., transplanted...... 2550
2 to $3 \mathrm{ft}$., transplanted........ 3000
3 to $4 \mathrm{ft}$., transplanted........ 3550

Barberry, Purple (Berberis purpurea).

Similar to Berberis vulgaris in habit, but with fine purple leaves that contrast beautifully with its flowers and with other shrubs. $\quad 10 \quad 100$

18 to $24 \mathrm{in}$., nursery row.. $\$ 200 \$ 1500$

18 to 24 in., transplanted. $250 \quad 2000$

2 to $3 \mathrm{ft}$., transplanted... $300 \quad 2500$

3 to $4 \mathrm{ft}$., transplanted... 350,3000

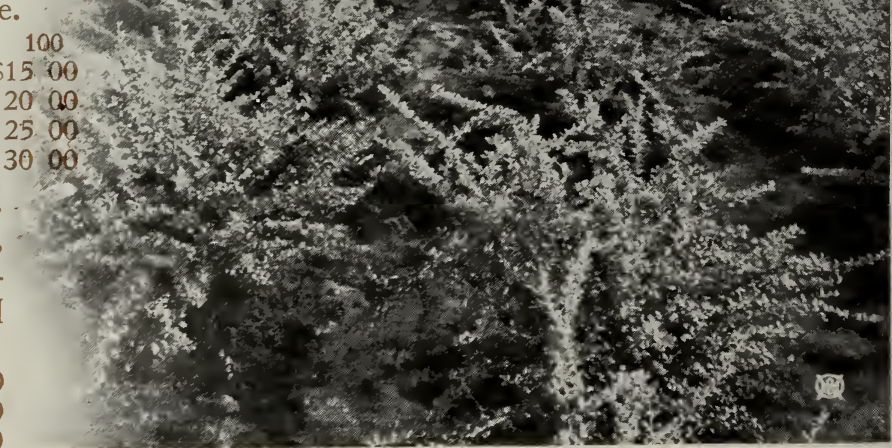

A block of Thunberg's Barberry-at The Park Nurseries (see p. 45) 


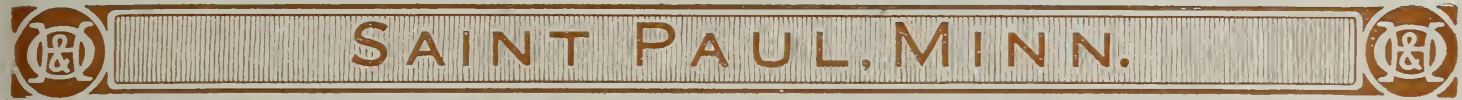

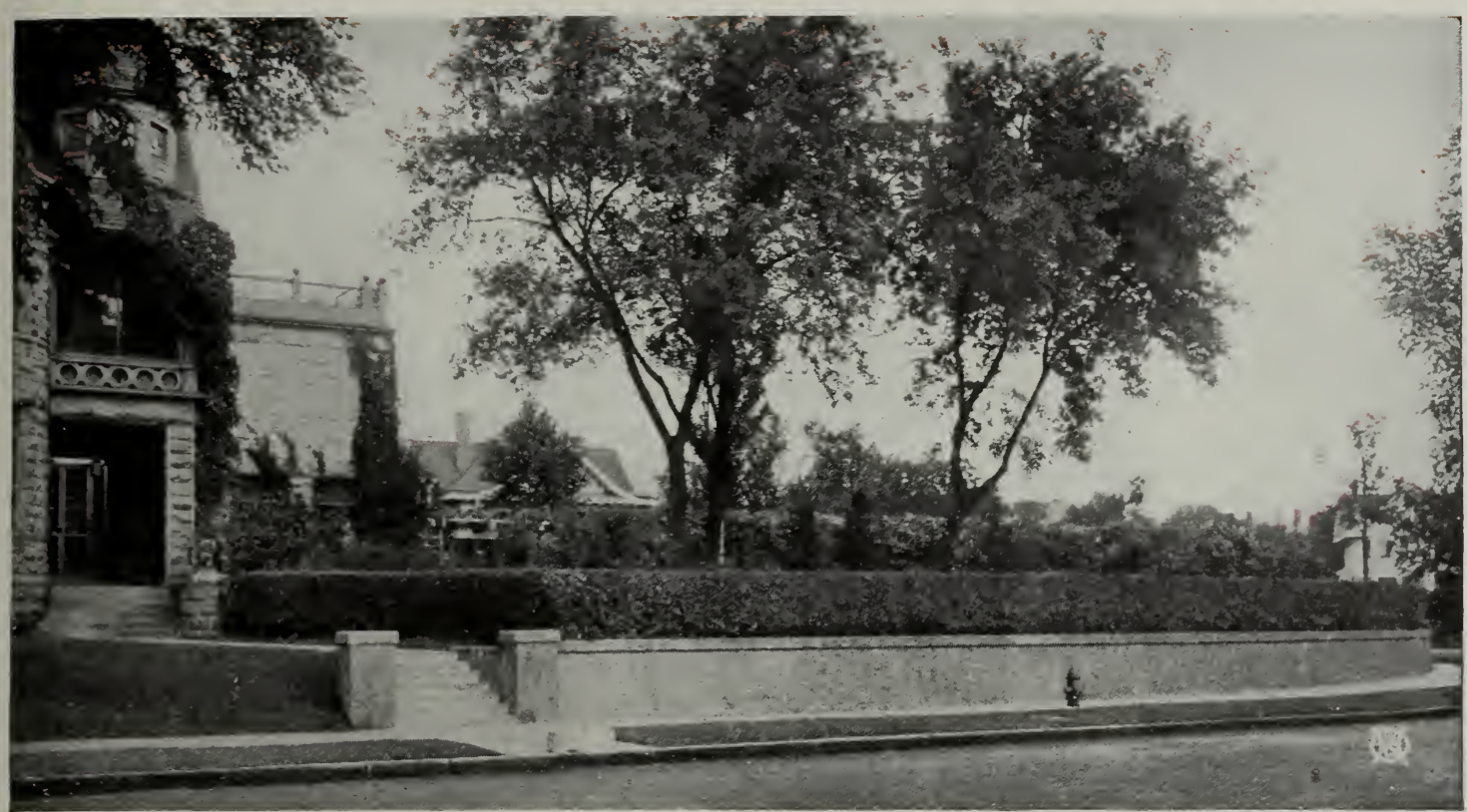

The Buckthorn makes one of the finest bedges for our section. The foliage grows clear to the ground, and the plants can be trimmed to almost any form

\section{DECIDUOUS HEDGES, continued}

Barberry, Thunberg's (Berberis Thunbergii). Inimitably neat and dense in growth, barely 3 feet high under the best conditions, yet quite graceful because of its drooping branches.
12 to 18 in., nursery row..

18 to 24 in., nursery row...

18 to 24 in., transplanted.

24 to 30 in., transplanted.

30 to 36 in., transplanted.
Prices of Buckthorn

18 to 24 in., nursery row.

18 to 24 in., transplanted.

2 to $3 \mathrm{ft}$., transplanted. . .

3 to $4 \mathrm{ft}$., transplanted.

4 to $5 \mathrm{ft}$., transplanted.

5 to $6 \mathrm{ft}$., trans., heavy, bushy.
$\$ 1250$

$\begin{array}{llll}2 & 00 & 17 & 00\end{array}$

2502000

$350 \quad 2500$

$500 \quad 4000$

Buckthorn (Rbamnus catbarticus). This is probably the hardiest of all our hedge plants; when trimmed it makes a beautiful hedge, and can be shaped as desired.

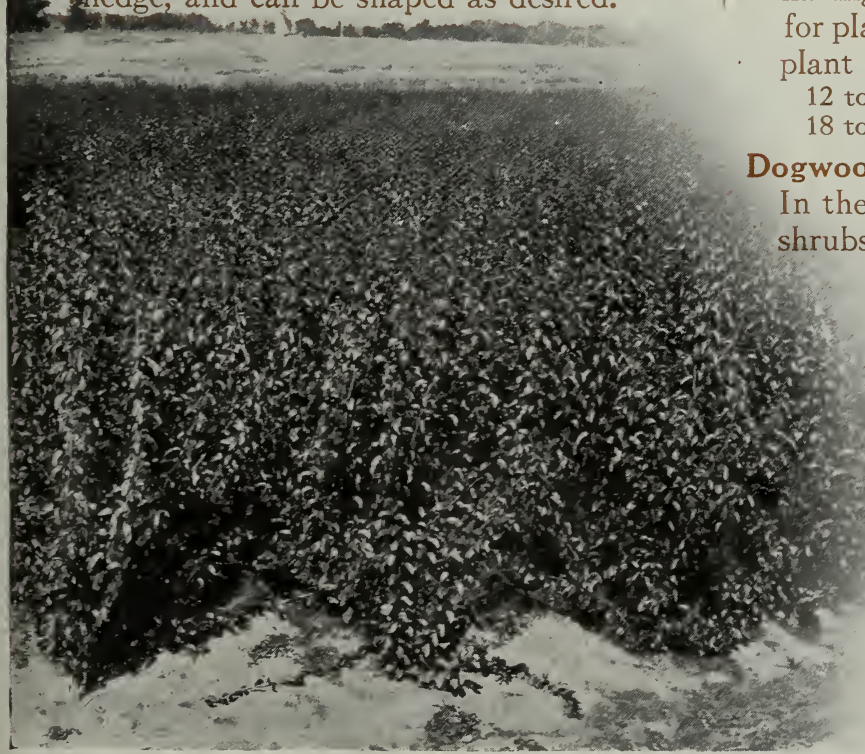

Bucktborn plants like this make superior bedges $\$ 150 \quad \$ 1200$ $200 \quad 1500$ $250 \quad 2000$ $300 \quad 2500$

$500 \quad 4000$

$600 \quad 5000$

Cotoneaster acuminata. A dense-growing shrub with dark green, glossy, oval leaves. The best hedge plant for the Northwest. Perfectly hardy and resembles Privet, which is used so extensively in the East but which is not hardy here. We are offering this for the first time, having a few thousand plants that are ready for planting, but predict it is the coming hedge plant for this section. $\quad 10 \quad 100$

12 to 18 in., transplanted........\$3 $00 \$ \$ 2500$

18 to 24 in., transplanted......... $400 \quad 3500$

Dogwood, Red-twigged (Cornus Sibirica alba). In the winter this is the most showy of all the hrubs, standing out bright and cheerful with its brilliant red bark. $\quad 10 \quad 100$ 2 to $3 \mathrm{ft}$., nursery row...\$2 $00 \quad \$ 1700$

2 to $3 \mathrm{ft}$., transplanted. . $250 \quad 2000$ 3 to $4 \mathrm{ft}$., transplanted. . $300 \quad 2500$

4 to $5 \mathrm{ft}$., transplanted, extra-heavy, bushy... $500 \quad 4000$

Honeysuckle, Red Tartarian (Lonicera Tatarica). One of our hardiest and best-known shrubs in the Northwest. It should be planted only in small sizes, so as to make them branch close to the ground. $10 \quad 100$ 2 to $3 \mathrm{ft}$., nursery row...\$2 $00 \quad \$ 1700$ 2 to $3 \mathrm{ft}$., transplanted. $250 \quad 2000$ 3 to $4 \mathrm{ft}$., transplanted. . $300 \quad 2500$ 4 to $5 \mathrm{ft}$., transplanted. . $500 \quad 4000$ 


\section{(웅) THE PARK NURSERIES (18)}

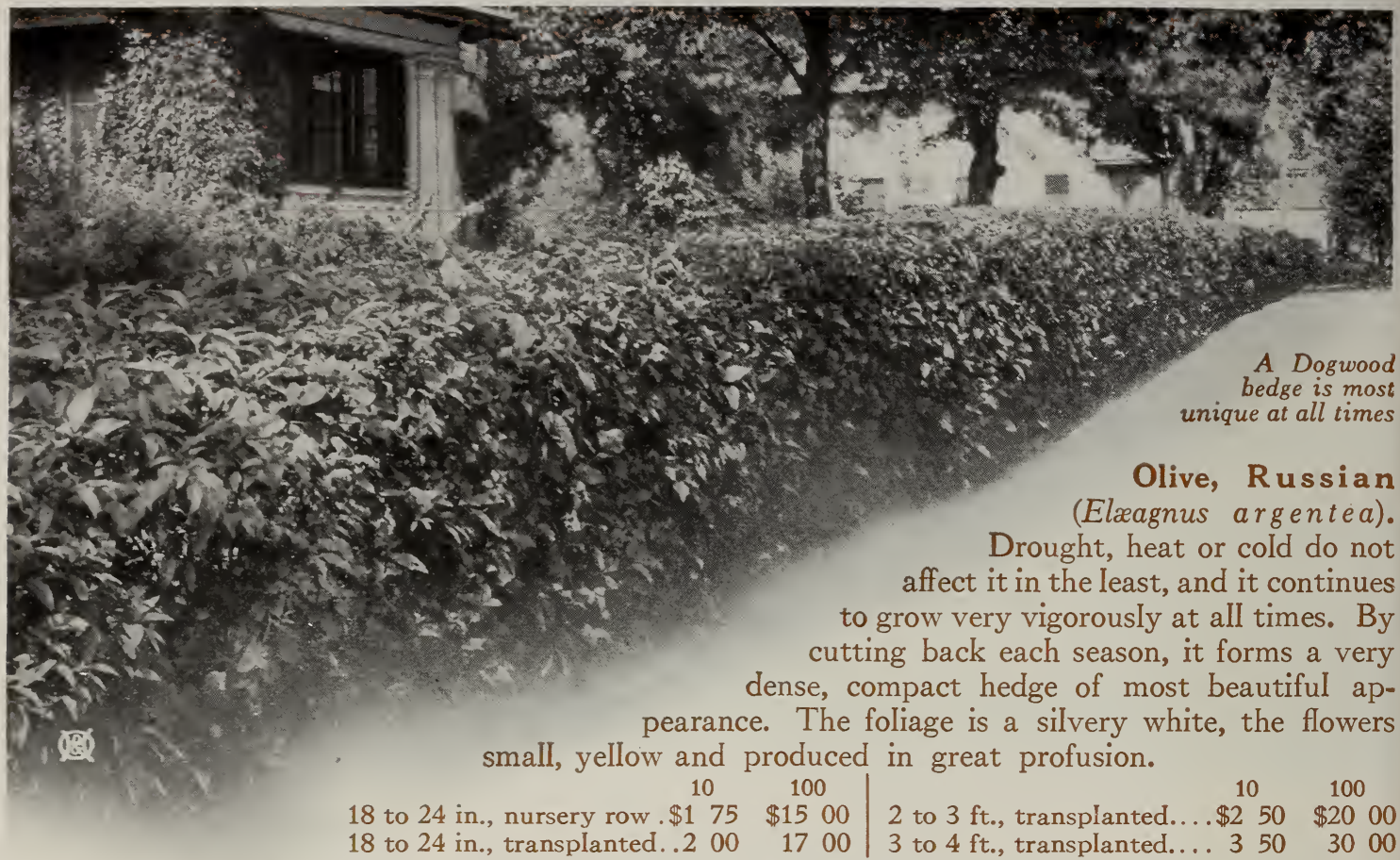

Privet, California (Ligustrum ovalifolium). Its dark green foliage, hanging weIl into the winter, makes it almost an evergreen, and is very attractive. We cannot recommend this in the Northwest, as it is not sufficiently hardy, but we can recommend it south of central Iowa. North of that \begin{tabular}{lll|rr} 
something else should be used. 10 & 100 & 10 & 100
\end{tabular} 2 to $3 \mathrm{ft}$., nursery row......... \$2 $50 \quad \$ 1500 \mid 3$ to $4 \mathrm{ft}$., nursery row ...........\$3 $00 \quad \$ 2000$

Privet, Ibota (Ligustrum Ibota). Dark, oval foliage, contrasting well with the prominent racemes \begin{tabular}{ccc|ccc} 
of white, fragrant flowers. & 10 & 100 & & 10 & 100 \\
2 to $3 \mathrm{ft}$., transplanted.......... $\$ 2$ & 50 & $\$ 20$ & 00 & 3 to $4 \mathrm{ft}$., transplanted............. $\$ 350 \quad \$ 3000$
\end{tabular}

Privet, Regel's (Ligustrum Regelianum). A low, dense shrub, with almost horizontally spreading branches; it is absolutely hardy, graceful and suffciently dense for hedge purposes without any trimming. $\quad 10 \quad 100 \quad \begin{array}{lllll}10 & 10\end{array}$ 18 to 24 in., nursery row ........ $\$ 200 \$ 1500 \mid 2$ to $3 \mathrm{ft}$., nursery row $\ldots \ldots \ldots \ldots \ldots \$ 250 \$ 2000$

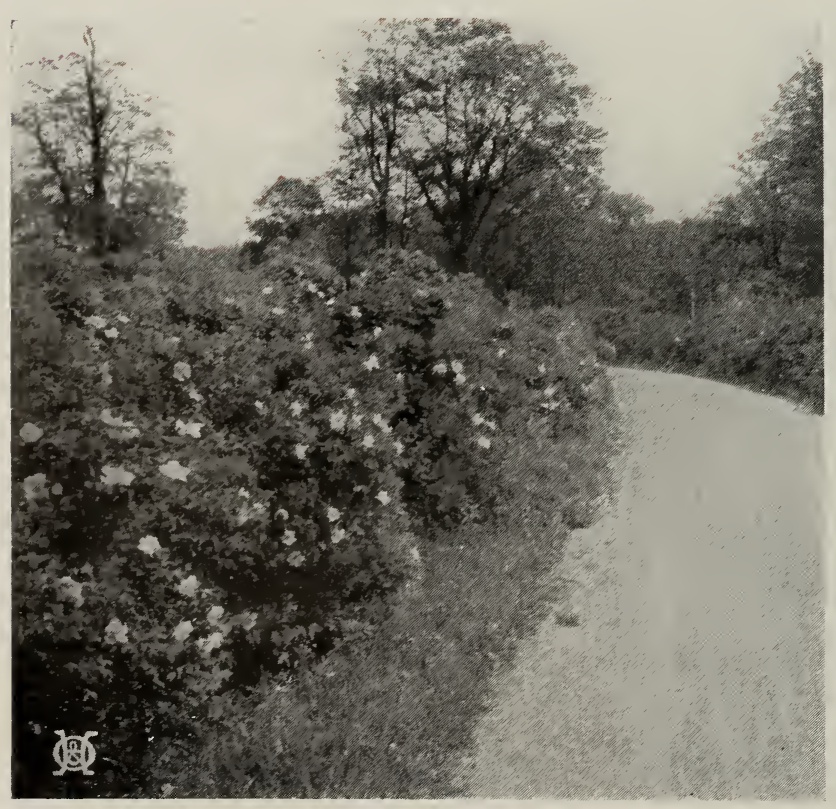

The Rosa rugosa makes a good border for drive or walk
Quince, Japan (Cydonia Japonica). The brilliant crimson flowers are very showy and attractive, and are produced before the glossy green leaves in the spring.

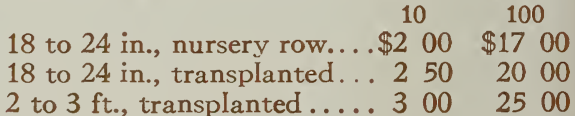

Rosa rugosa (Japanese Rose). Forms a beautiful hedge; large, dark green, glossy foliage; terminal clusters of ten to twelve flowers, each 3 inches in diameter.

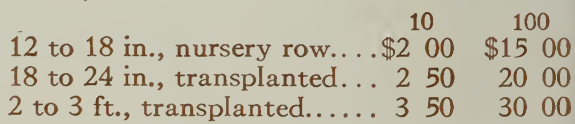

Spiraa Van Houttei. One of the most desirable shrubs known. Can be used effectively in almost any planting or grouping.

$10 \quad 100$

18 to 24 in., nursery row... \$2 $\$ 20 \$ 1500$

2 to $3 \mathrm{ft}$., nursery row....... $250 \quad 2000$

3 to $4 \mathrm{ft}$., nursery row.......... $300 \quad 2500$

3 to $4 \mathrm{ft}$. , transplanted...... $500 \quad 4000$ 


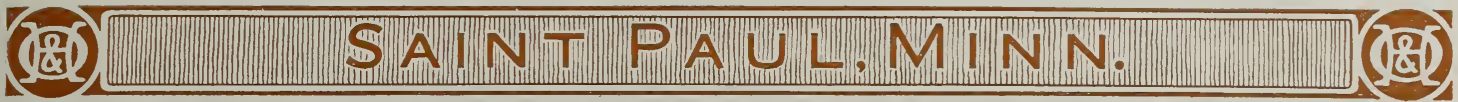

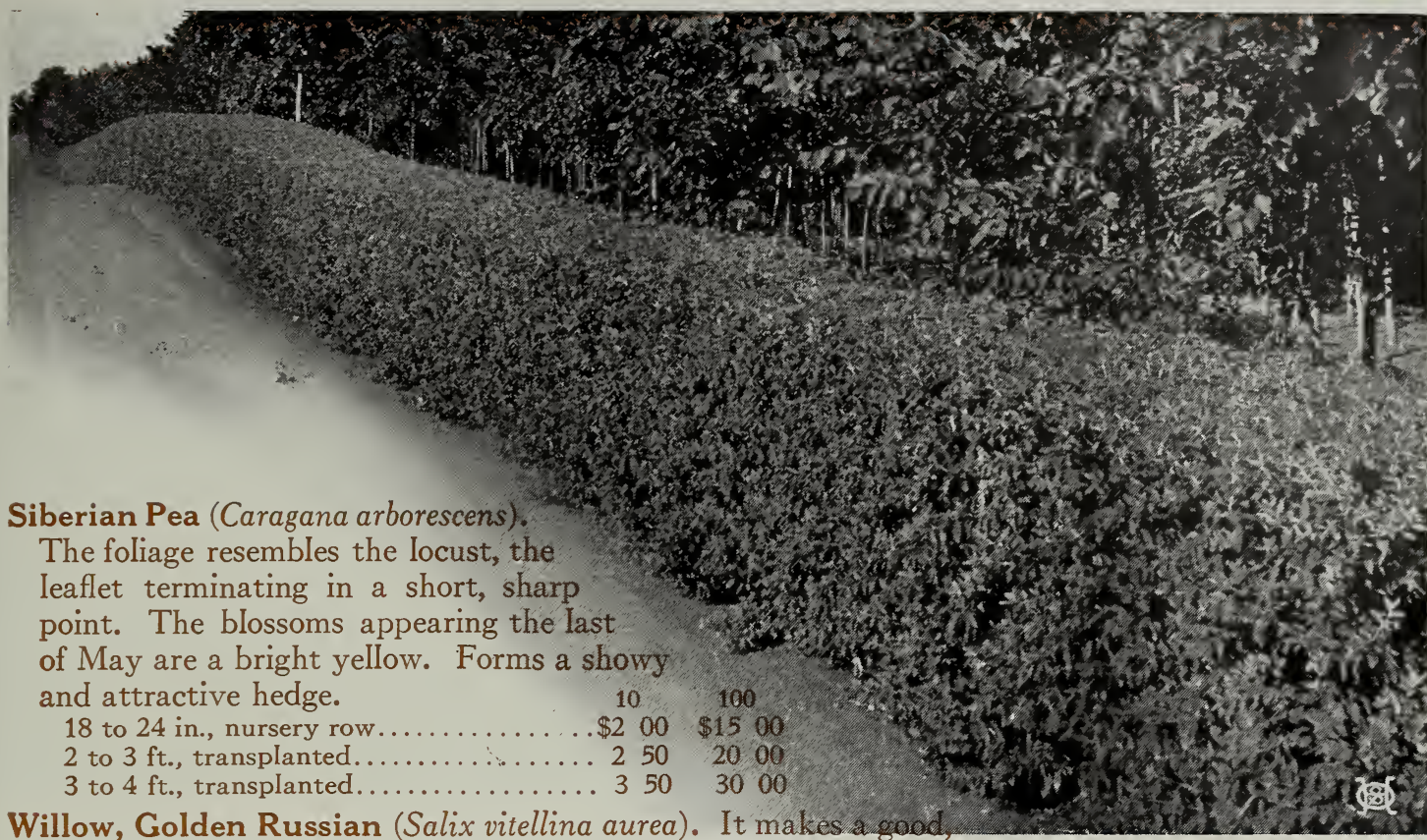

Willow, Golden Russian (Salix vitellina aurea). It makes a good, practical tree of symmetrical form. One of its strongest ornamental features is the bright, clear golden yellow bark, which offers a pleasing contrast wherever it is used.

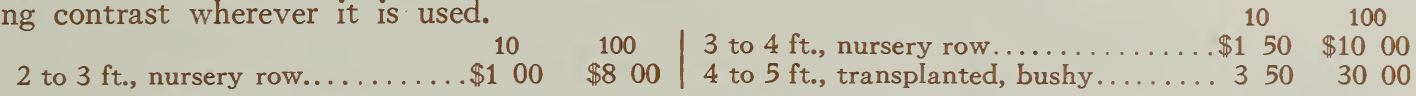

Willow, Laurel (Salix pentandra). Bark is brownish green. Foliage is a deep, shining green, closely resembling that of the Iaurel. Thrives equally well on high or low ground. An especially desirable plant for forming hedges near the water.

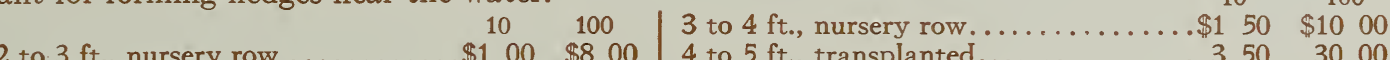

\section{EVERGREEN HEDGES}

Arborvitæ, American (Thuya occidentalis). The American Arborvitæ is one of our best-known American Evergreens. It is perfectly hardy, and adapts itself very readily to hedge purposes.

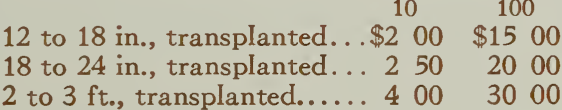

Spruce, Norway (Picea excelsa). This tree is perhaps the most popular member of the Spruce family, planters being very familiar with its habits. Norway Spruce is a very fast grower, and is very hardy, adapting itself to almost any and all soils. One of the finest. $10 \quad 100$

12 to 18 in., transplanted... \$2 $00 \quad \$ 1500$ 18 to 24 in., transplanted... 2502000 2 to $3 \mathrm{ft}$., transplanted..... $400 \quad 3000$

Spruce, White (Picea alba). A very hardy variety, used largely in ornamental groups. Resembles the other members of the Spruce family in its habits and growth. A fairly rapid grower; foliage light green in color. $\quad 10 \quad 100$

12 to $18 \mathrm{in}$., transplanted. . \$2 $00 \quad \$ 1500$

18 to 24 in., transplanted... $350 \quad 2500$

2 to $3 \mathrm{ft}$., transplanted .... $600 \quad 4500$

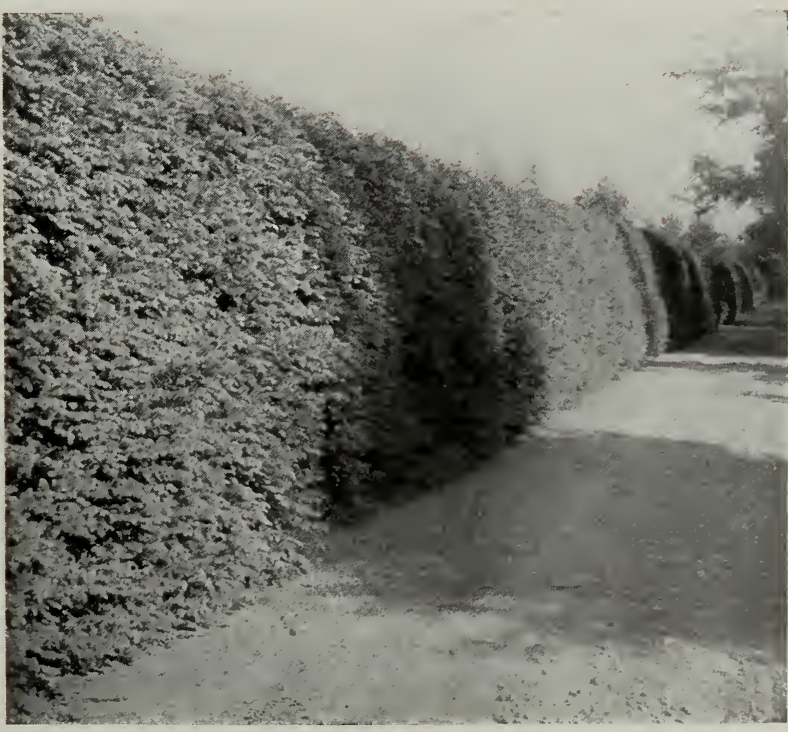

Wbite Spruce Hedge 


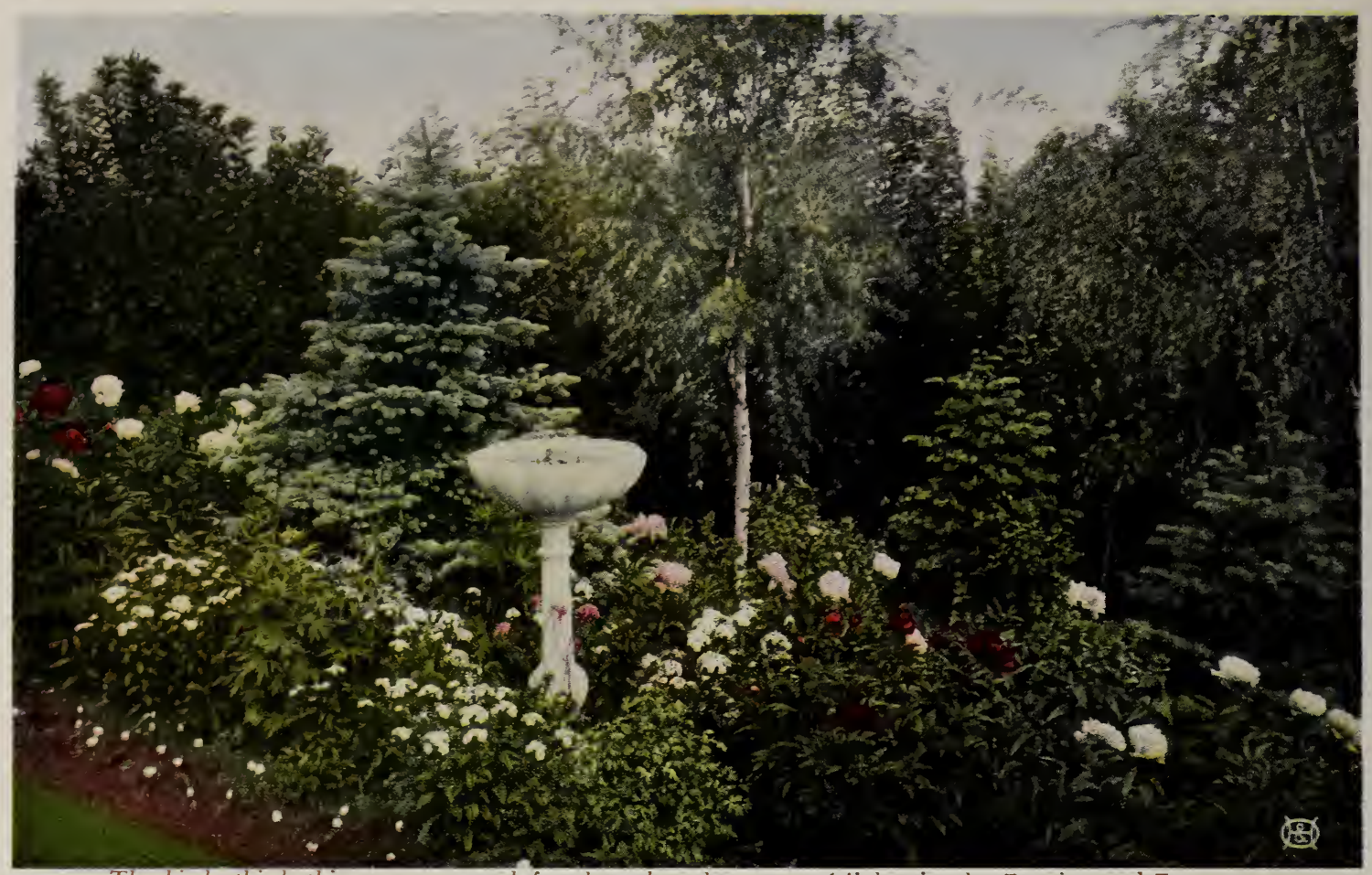

The birds tbink tbis was prepared for tbem, but the owner deligbts in the Peonies and Evergreens

\section{HARDY PERENNIALS}

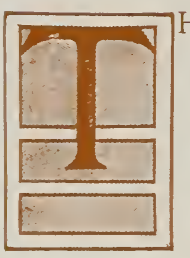

HE RETURN to popular favor of the oId-fashioned flowers infuses into our gardens a peculiar charm, rare beauty and fragrance, that is possible only with hardy perennials. Each day, from the time the tree-buds first burst in the spring until the leaves are gone, the hardy perennial garden is of constant interest and delight. All the old favorites are found here, with the new hybrids and selections.

Ideas differ widely among experts as to the best methods of care and arrangement of the hardy garden or border. Much depends upon the location and size of the grounds at one's disposal, while the owner's individual taste must be carefully considered.

Situation. - The most effective location is a good, open border, backed by a hedge, fence, trellis or building. Some of the taller-growing kinds are used as a background; then other sorts of shorter growth, graduating down to the grass line. Perennials are frequently planted among, or in front of shrubs, giving bloom when many of the shrubs are through flowering and supplying a background for the perennial blossoms.

Soil and Planting.-Good cultivation and good soil are the secret of a beautiful garden. Each season the soil should be mulched with well-rotted manure, and, in the spring, spade this into the soil. Bone meal can be used, but we prefer the former as a fertilizer, as it leaves the soil looser, besides adding humus.

Excepting a few woody and robust perennials, the best time to plant in the Northwest is in the spring.

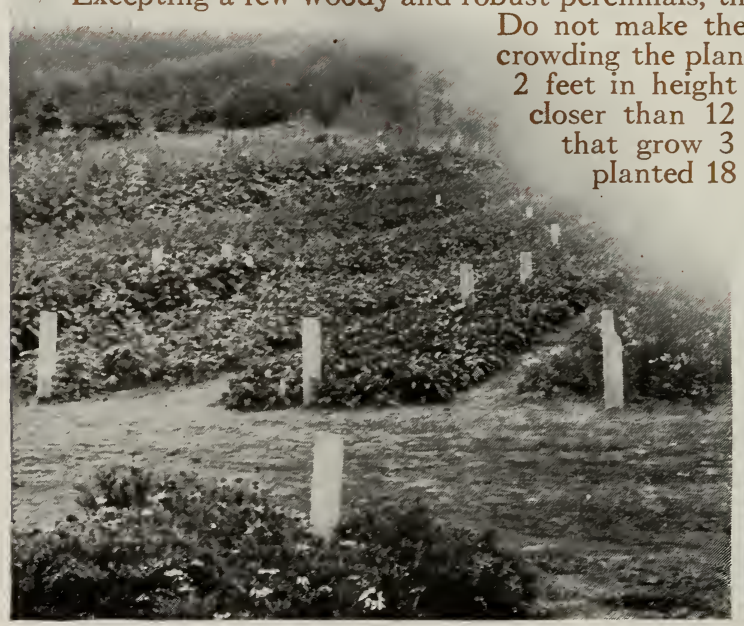

Do not make the common mistake of

rowding the plants. Those that grow

feet in height should not be set that grow 3 feet should be planted 18 inches apart. 1 .
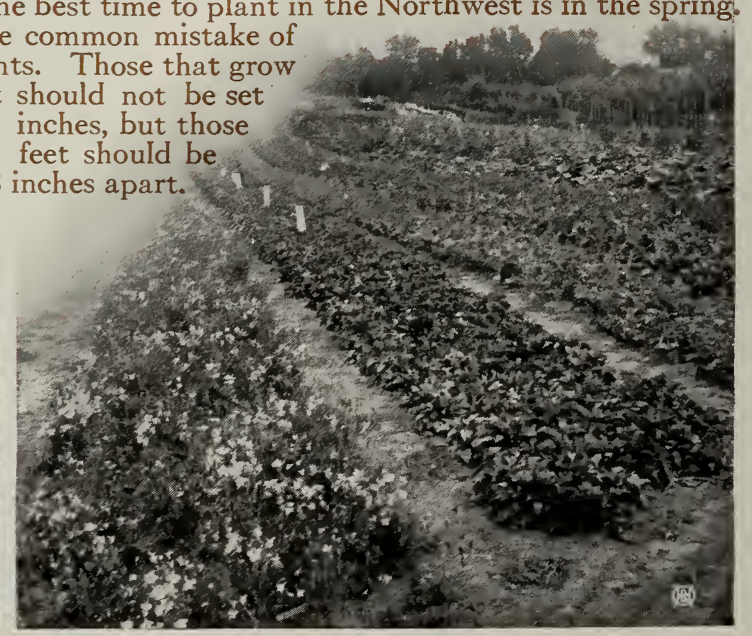

We grow Hardy Perennial Plants by the million in our nursery 

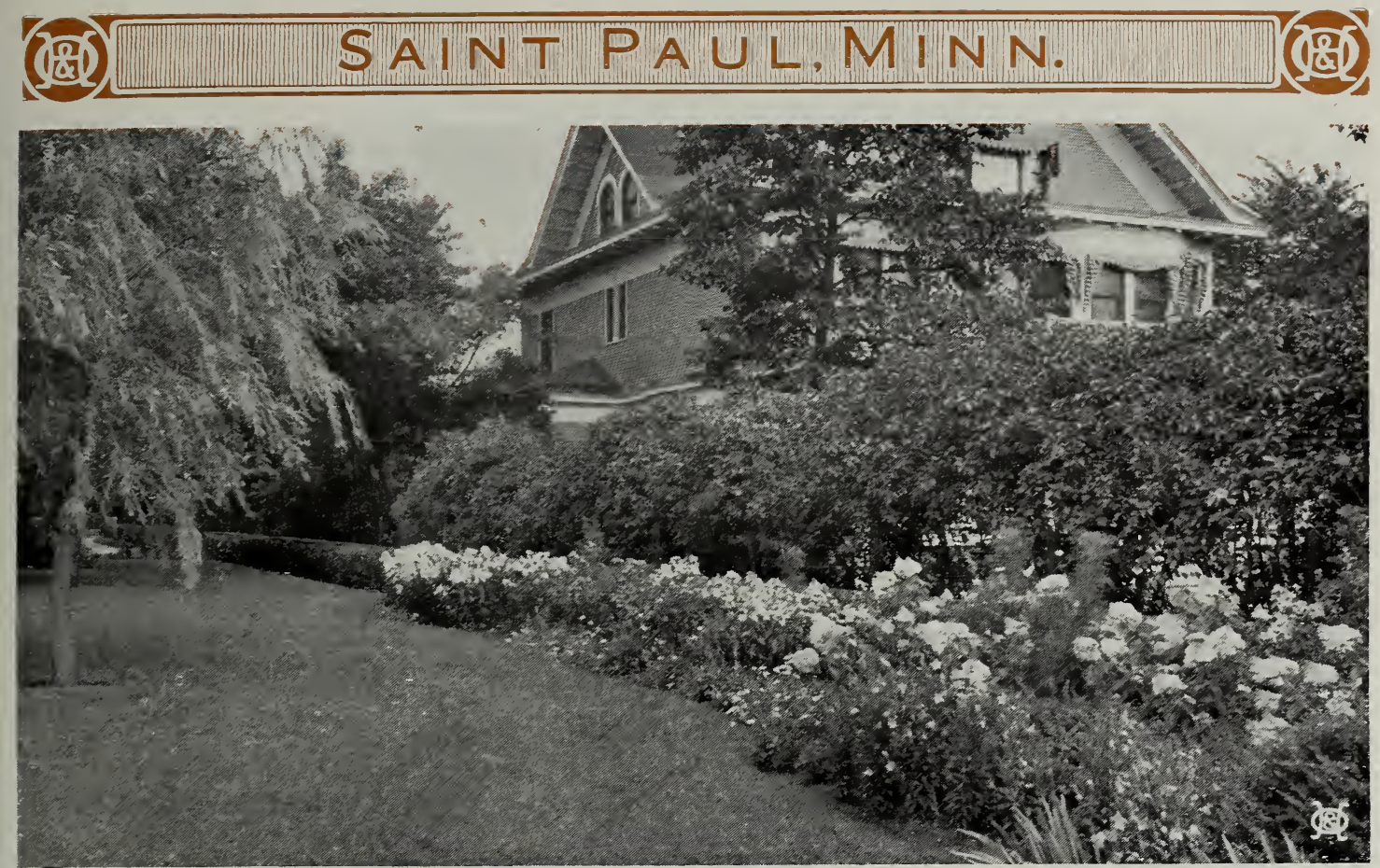

A perennial border that gives color during the entire summer

\section{HARDY PERENNIALS, continued}

Note.-We grow the very finest perennials, and agree to deliver in good condition, but they are sold with the understanding that, should any fail to grow, it is the purchaser's loss. Owing to the low price at which they are sold, we do not guarantee them to grow.

When the price is $15 \mathrm{cts}$. each.

When the price is $20 \mathrm{cts}$. each.

When the price is $25 \mathrm{cts}$. each.

When the price is $35 \mathrm{cts}$. each.

When the price is $50 \mathrm{cts}$. each

When the price is $50 \mathrm{cts}$. each............................ 6 will be furnished for $\$ 2.50$, I2 for $\$ 5$
Plants priced at I5 cts. are strong, one year old. "Strong," plants are two years old. All are more effective

6 will be furnished for $75 \mathrm{cts}$., I2 for $\$ \mathrm{I} .50$ 6 vill be furnished for $\$ 1$, I2 for $\$ 2$

6 will be furnished for $\$ 1.25$, I2 for $\$ 2.50$

6 will be furnished for $\$ I .75,12$ for $\$ 3.50$

6 will be furnished for $\$ 2.50$, I2 for $\$ 5.50$
Achillea, Boule de Neige (BaIl of Snow). An improvement on The Pearl; the flowers are of more perfect form, with fuller centers, which makes it appear purer in color. 15 cts.; strong, 25 cts.

A. Millefolium (Rosy Milfoil). Blooms aII summer. Has a rosy red flower on stems from 12 to 18 inches. The foliage is deeply cut and ornamental. Used in wild gardens; also with shrubbery. 15 cts.; strong, 25 cts.
Achillea Ptarmica, "The Pearl." (White Milfoil). Blooms in July and August. Height 2 feet; flowers small, but the plant is covered with a mass of white bloom; used for gardens and shrubbery. 15 cts.; strong, 25 cts.

A. tomentosa (Woolly Yarrow). Handsome, cut foliage and bright yellow flowers in a multitude of flat heads during June. Height about 12 inches. 15 cts.; strong, 25 cts.

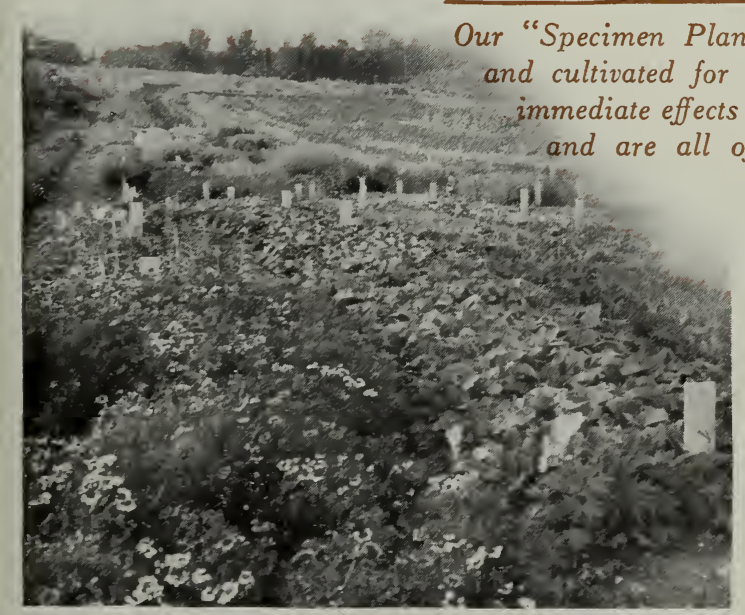

s" are especially grown

and cultivated for the purpose of creating immediate effects in the bome grounds,

The vigor and strengtb of our Hardy Perennial Plants is most remarkable

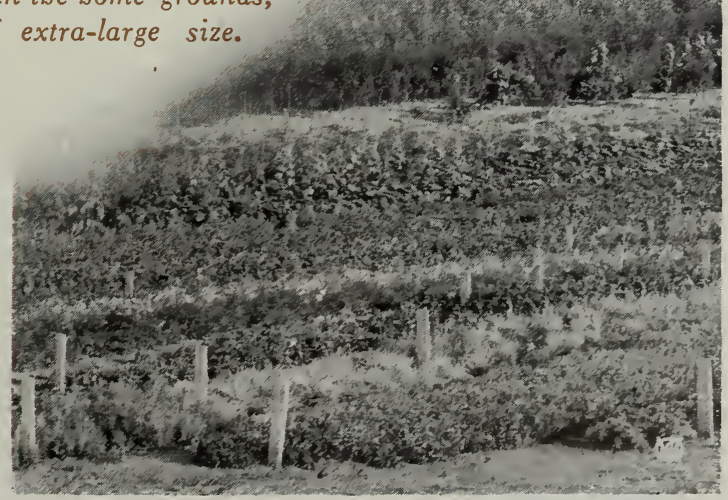




\section{(190.62) (1960)}

\section{HARDY PERENNIALS, continued}

Aconitum Storkianum (Monkshood, or Helmet Flower). Beautiful, rich, deep blue flowers in Iarge spikes. July and August. 15 cts.; strong, 25 cts.

Agrostemma (Rose Campion). Stout, erect-growing plants, with silvery foliage, which contrasts well with the showy flowers, which are produced during June and July. 15 cts.; strong, 25 cts.

Egopodium Podograria variegatum (Bishop's Weed). A rapidgrowing plant, with neat green-and-yellow variegated foliage, thriving in any soil; makes a frne border for a bed of shrubs or for covering waste ground; 1 foot. 15 cts.; strong, 25 cts.

Alyssum saxatile compactum (Golden Tuft, or Basket of Gold). Season of blooming, May and June. Height 8 to 10 inches. Golden yellow. An excellent low-spreading plant for rockery or border. 15 cts.; strong, 25 cts.

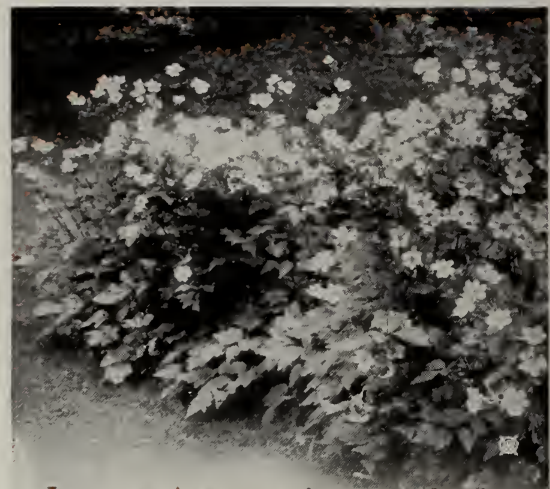

Japanese Anemones in mass planting

Anemone, Whirlwind (Wind Flower). Season of blooming, August to November. Height 2 to 3 feet. Flowers 2 to 3 inches across, very double, with several rows of petals. Creamy white. Plant needs cool, moist location. Can be planted in clumps or solid beds. 15 cts.; strong, 25 cts.

Anchusa Italica, Dropmore Variety (Sea Bugloss). A grand improvement on the old Italian Alkanet; grows 5 feet high and produces its pretty gentian-blue flowers throughout the entire summer; one of the best blue perennials. 25 cts.

A., Opal. Similar to the above, but lustrous, light blue in color. 25 cts.

Anthemis tinctoria Kelwayi (Hardy Marguerite). Blooms all summer. Height 18 to 24 inches. Gives a continuous showing throughout the season, of daisy-like flowers. Color of bloom golden yellow. 15 cts.; strong, 25 cts.

Aquilegia Canadensis (Columbine). Blooms from June to August. Height 2 feet. Flowers red and yellow, held gracefully on long stems. A strong-grower and free-bloomer. An old favorite, and does well in almost any location. 15 cts.; strong, 25 cts.

A. chrysantha (Golden-spurred Columbine). Blooms from June to August. Height 3 feet. Color golden yellow. Desirable to plant in partially shady places, or in borders. 15 cts.; strong, 25 cts.

A. cœrulea (Rocky Mountain Columbine). Blooms from May to July. Height 12 to 18 inches. Color pure blue. 15 cts.; strong, 25 cts.

A. Californica hybrida. Long-spurred flowers in a variety of coloring

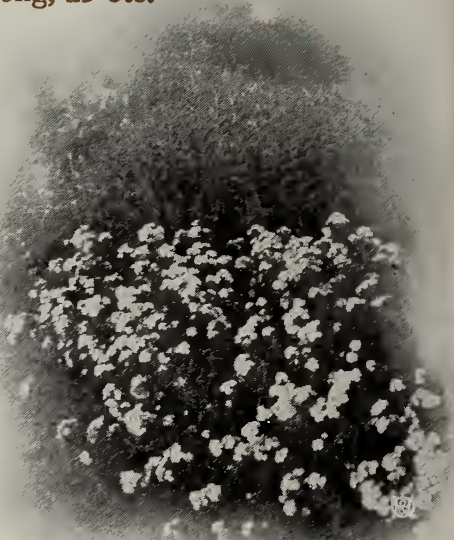

Acbillea Ptarmica, "The Pearl" (see page 49) such as yellow, pink, flesh, red, etc. These are very attractive and more beautiful than the standard types. 20 cts.; strong, 25 cts.

Arabis alpina (Rock Cress). Blooms from April to May. Height 6 inches. A very low-spreading plant, completely covered with pure white flowers. Used for borders or around walls or for rockery. Fine for massing. 15 cts.; strong, 25 cts.

Armeria formosa (Sea Pink). A fine variety, with deep crimson flowers, blooming through the summer. Fine for cutting purposes. $15 \mathrm{cts}$; strong, 25c.

Asclepias tuberosa (Butterfly Weed). Compact umbels of brilliant orange-colored flowers. 15 cts.

Aster, Hardy (Michaelmas Daisy, or Starwort). We offer a good selection in many colors. Asters are good for background planting, and bloom late. 15 cts.; strong, 25 cts.

A. Curtisii. Pale heliotrope; August and September. Height,

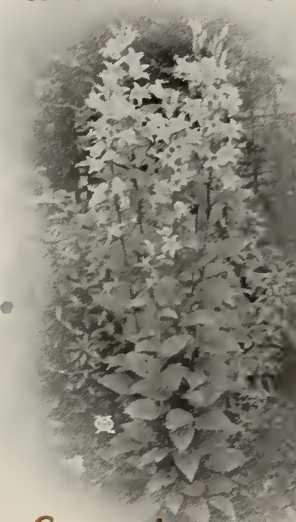

Campanula (see page 5 3 feet. 15 cts.; strong, 25 cts.

A. Novæ-Angliæ(New England Aster). Blooms late in summer. Height 4 feet. Color violet-purple. The finest and showiest of all Hardy Asters. Strong grower and free-bloomer. This is often used in background of plantings, making a showy and bright appearance. 15 cts.; strong, 25 cts.

A., Mrs. F. W. Raynor. Large, rich crimson-purple flowers. Height, 4 feet. 15 cts.; strong, 25 cts.

A. rosea. Bright purplish mauve. Height 4 feet. 15 cts.; strong, 25 cts.

A., Snowflake. Very free; pure white. Height 18 inches. 15c.; strong, 25c.

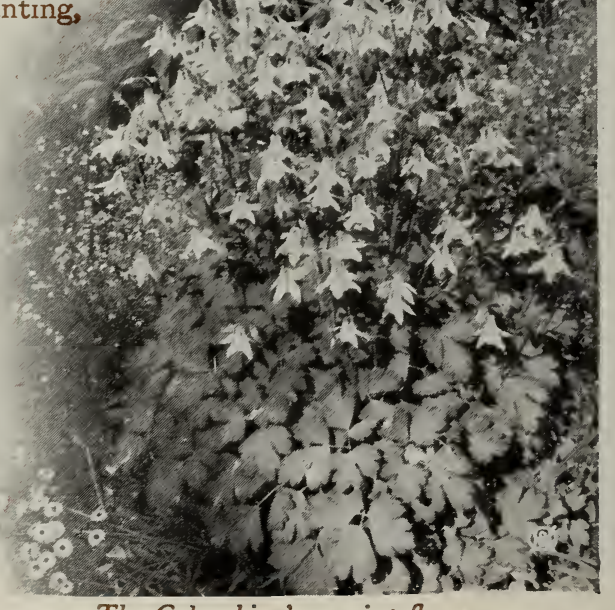

The Columbine's quaint flowers 


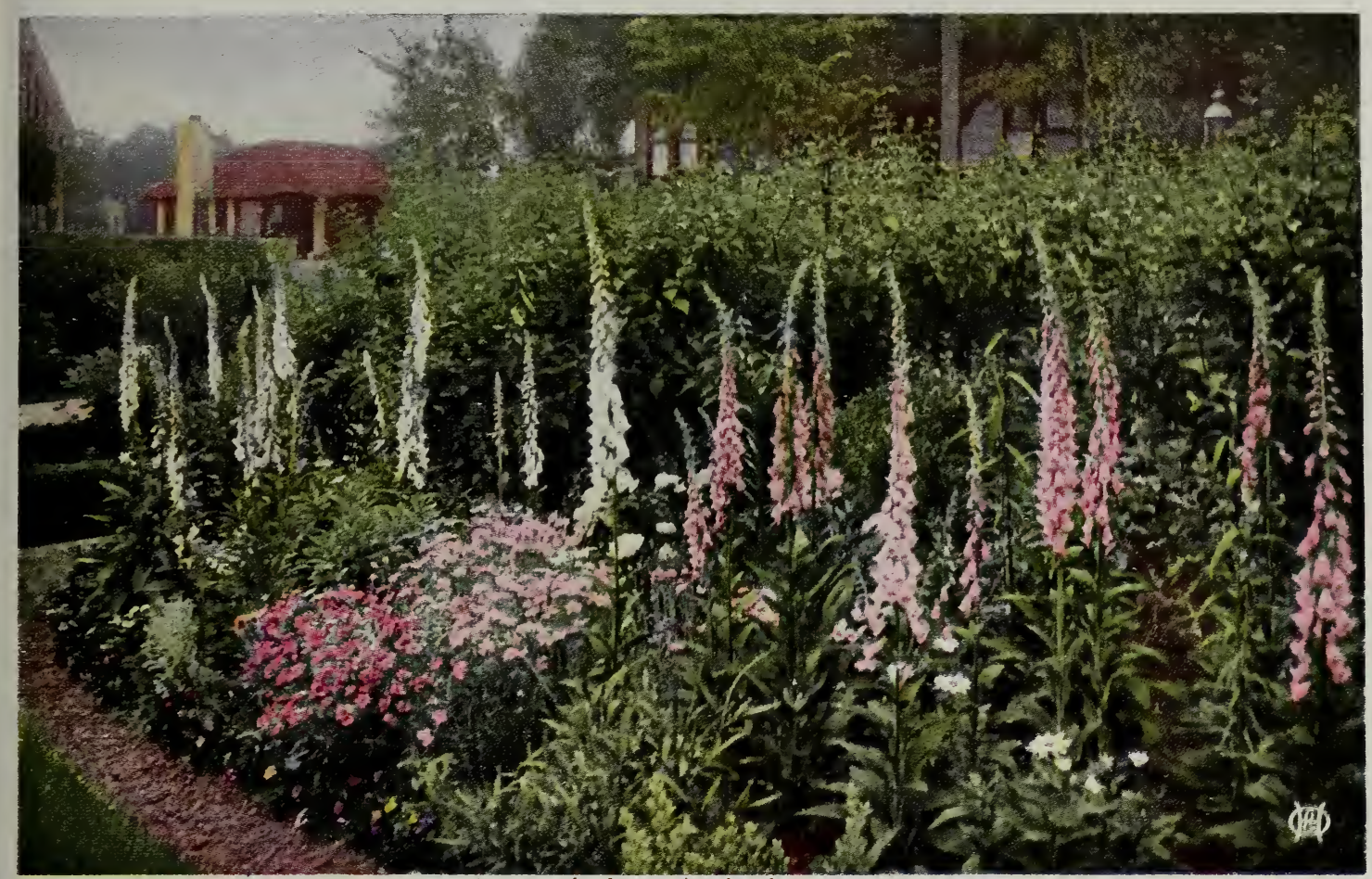

The charm of a bardy border is greatly increased when suitable plants are chosen. The stately spikes of the Digitalis rise like catbedral towers among the low-growing Daisies, Diantbus and Pansies

\section{HARDY PERENNIALS, continued}

Aster, White Queen. Fine, pure white. Height 4 feet. 15 cts.; strong, 25 cts.

Baptisia australis (FaIse Indigo). Blooms June and July. Height 2 to 3 feet. Color dark blue. 15 cts.; strong, 25 cts.

Bellis perennis (English Daisy). Blooms April to June. Height 6 inches. Red, white, and pink, double, very popular spring flowers. 15 cts.

Bleeding Heart. See Dielytra.

Bocconia cordata (Plume Poppy). Blooms July and August. Height 6 to 7 feet. Flowers creamy white. Fine for backgrounds. 15c.; strong, 25c.

Boltonia asteroides (FaIse Chamomile). Blooms July to October. Height 4 feet. Color white. A strong plant that is covered during the summer and autumn with hundreds of smaIl white flowers. 15 cts.; strong, 25 cts.

B. latisquama. The same as above, except that the flower is a pale pink. 15 cts.; strong, 25 cts.

Campanula Carpatica (Bellflower, or HarebeII). Blooms July to August. Height 8 inches. Color blue. Of dwarf habit, especially used for borders of beds or for edging; also for rockery. Its deep blue flowers are very attractive and almost always in bloom. 15 cts.; strong, 25 cts.

C. Carpatica alba. Same description as above, except flower is white. 15 cts.; strong, 25 cts.

C. calycanthema (Cup-and-Saucer; Canterbury BeII). Blooms July and August. Height 2 feet. Colors mixed-blue, rose and white. 15 cts.; strong, 25 cts.

C. glomerata (Clustered Bellflower). Blooms all summer. Height 18 inches. Color violet-blue. Profuse bloomer, and its bell-shaped flowers are always attractive. 15 cts.; strong, 25 cts.

C. Medium (Canterbury BeIIs). These come in blue, rose, white, and choice mixed colors. Height 3 feet. 15 cts.; strong, 25 cts.
Campanula persicifolia (Peach Bells). Blue and white flowers during June and JuIy. Height 2 feet. 15 cts.; strong, 25 cts.

C. pyramidalis (Chimney BeIlflower). Flowers in August. The most conspicuous of all the Campanulas, forming a perfect pyramid. Height 4 to 5 feet. 15 cts.; strong, 25 cts.

Centaurea montana (Perennial Cornflower). Grows 2 feet high, bearing Iarge, violet-blue flowers from July to September. 15 cts.; strong, 25 cts.

Chrysanthemum maximum (Moonpenny Daisy). Blooms JuIy to October. Height 3 feet. Color white. A strong grower, with a profusion of Iarge, daisy-like flowers. 15 cts.; strong, 25 cts.

C. hybridum (Shasta Daisy). Blooms all summer. Height 12 to 15 inches. Color white. The flowers are of Iarge size, often 4 inches in diameter, with numerous petals which are pure white, with a yellow center. 15 cts.; strong, 25 cts.

C. hybridum, Alaska. Blooms aII summer. Height 12 to 15 inches; color white. A great improvement over Shasta Daisy, being much larger, $41 / 2$ to 5 inches in diameter. Very free bloomer and much hardier than its parent. 25c.; strong, 50 cts.

Clematis, Shrubby. This type of Clematis is deserving of the greatest popularity. They form erect bushes 2 to 3 feet high; during their long period of bloom they are very attractive.

C. Davidiana. A most desirable variety, with fresh, bright green foliage and tubular, beIIshaped flowers of deep Iavender-blue during August and September; deliciously fragrant. 25c.; strong, 35 cts.

C. recta. Another fine variety, with handsome, pure white flowers in very large, showy clusters during June and July; very effective. 25 cts.; strong, 35 cts. 


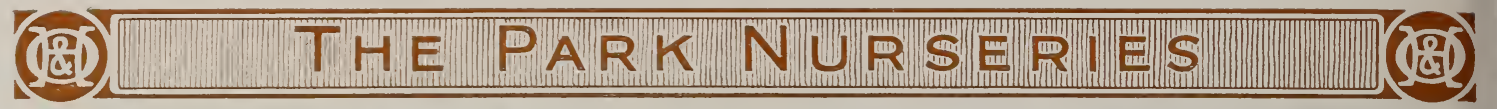

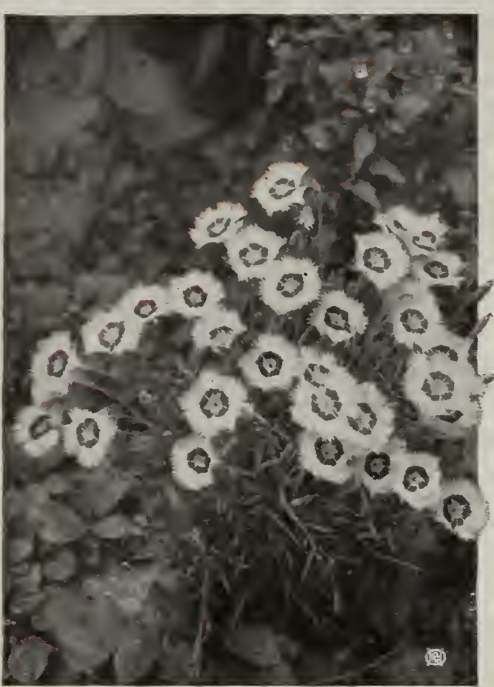

Brillant Hardy Pinks (see page 53)

HARDY PERENNIALS, continued

Coreopsis grandiflora. One of the most popular hardy plants. The flowers are a rich golden yellow, of graceful form and invaluable for cutting; the main crop comes during the latter part of June, but it continues in bloom the entire summer and autumn. It succeeds every-

C. lan ceolata (Tickseed). Blooms April to May. Height 2 feet. Color deep golden yellow. The best hardy yellow flowers for massing. Incessantly in bloom and one of the most attractive perennials.

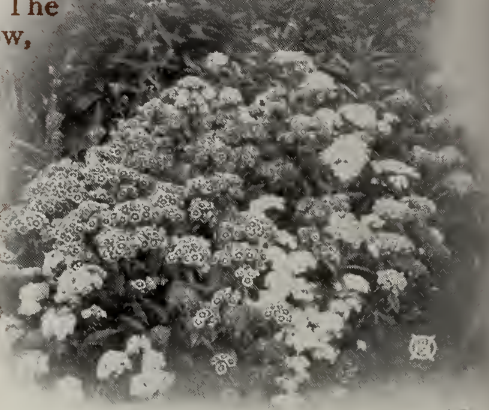

Sweet Williams (see page 53) It forms a compact clump, and is one of the best for cultivating. The flowers are on fairly long stems and are fine for cutting. 15 cts.; strong, 25 cts.

C. rosea. Blooms June to September. Height 12 inches. Color pink. A low-growing plant, used for borders of beds or clumps, or for rock-gardens. 15 cts.; strong, 25 cts.

Delphinium Chinense (Larkspur). Blooms June to August. Height 3 feet; color light blue. A lowgrowing variety, with pretty, fern-like foliage, and producing beautiful, deep blue flowers, which are very striking and attractive. Used largely for background. $15 \mathrm{cts}$; strong, $25 \mathrm{cts}$.

D. Chinense album. Similar to the above except that the bloom is white, and is very effective in large plantings when contrast in colors is desired. 15 cts.; strong, 25 cts.

D., Belladonna. The freest and most continuous blooming of all, never being out of flower from the end of June until cut down by hard frost. The clear turquoise-blue of its flowers is not equaled for delicacy and beauty by any other flower. 25 cts.; strong, 35 cts.

D. formosum. Blooms July to September. Height 4 feet. Color deep blue, with white eye. An old variety, but one of the most charming. Grows very tall, has a good, dark green foliage; is often used in background of gardens and is good for a low screen. This variety is unsurpassed in its deep, rich blue flowers. 15 cts.; strong, 25 cts.

D., Siberian Hybrids. These are the finest strain of mixed hybrids ever offered. Our original stock came from Siberia, and is of the hardiest type. Plants strong and vigorous, with large flowers; spikes vary from 18 to 24 inches in length, the flowers running to lighter shades of blue. 15 cts.; strong, 25 cts.

Dielytra spectabilis (Bleeding Heart). Blooms May to June. Height 2 feet. Flowers pink and white; heart-shaped. A well-known hardy perennial, producing its flowers freely in spring and early summer in graceful, drooping racemes, sometimes a foot in length. It has a beautiful foliage and is good for massing with shrubbery. 25 cts.; strong, 35 cts.

Digitalis purpurea (Foxglove). Blooms July to August. Height 4 feet. Colors, mixed. This old favorite is very well known and a general favorite. It gives abundance of bloom and is suited for background in plantings. 15 cts.; strong, 25 cts.

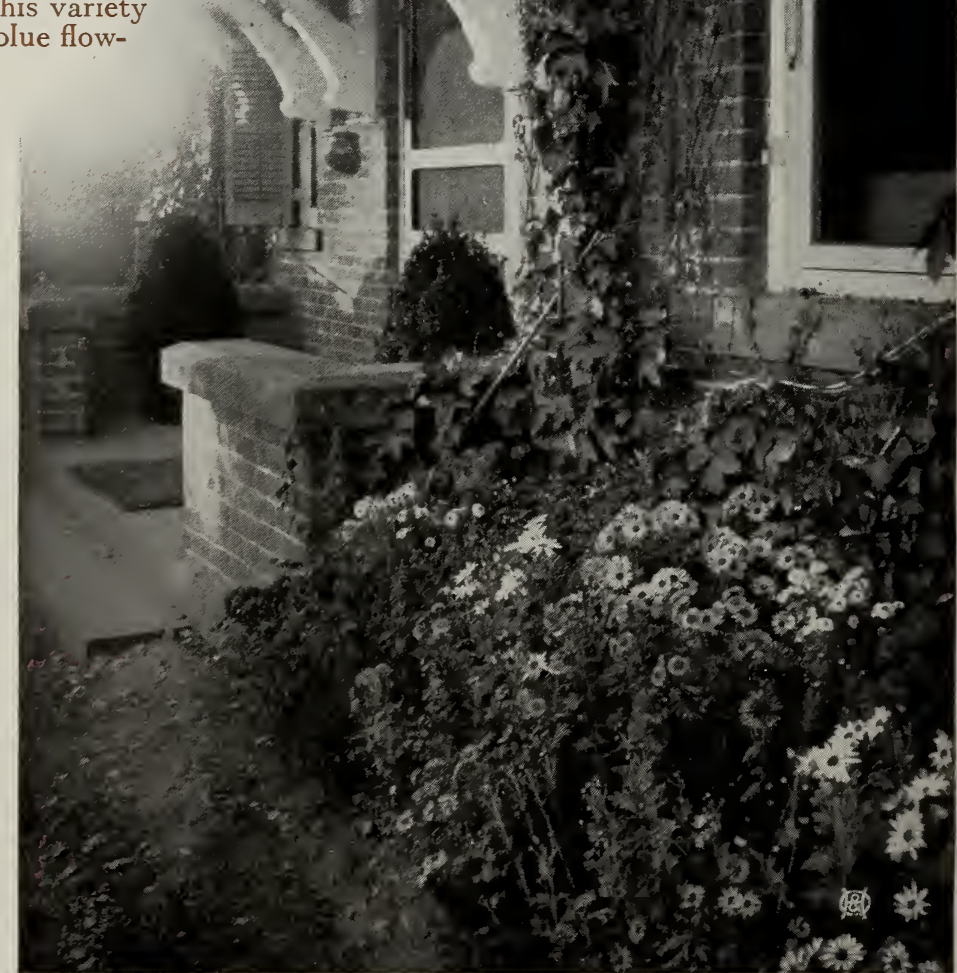

Shasta Daisies shine out effectively in the bardy border (see page 51) 
HARDY PERENNIALS, continued

Digitalis gloxiniæflora (Gloxinia-flowered Foxglove). A beautiful strain of finely spotted varieties. We offer them in White, Purple, Lilac, Rose or Mixed. 15 cts.; strong, 25 cts.

Dianthus barbatus (Sweet William). Blooms May to July. Height 12 to 18 inches; colors in assortment. Sweet Williams were usually one of the features in the gardens of our grandmothers and they continue just as popular today. With the improvement in recent years in size and coloring, they are one of the most attractive plants. We have these in an array of colors, single and double. These can be planted in masses or with shrubbery. 15 cts.; strong, 25 cts.

D. deltoides roseus (Hardy Pink). Blooms all season. Height 8 to 12 inches; light red. These old-time favorites need no description; they bloom all season and are very fragrant. Used for edging beds or in rockeries or wherever a low plant is needed. 15 cts.; strong, 25 cts.

D. deltoides albus. Blooms all season. Height 8 to 12 inches. Color white. 15 cts.; strong, 25 cts.

D. latifolius (Hybrid Sweet William). Blooms all summer. Height 15 inches. Color brilliant crimson. A beautiful summer bedding variety, producing masses of brilliant fiery crimson flowers throughout the entire season. 25 cts.; strong, 35 cts.

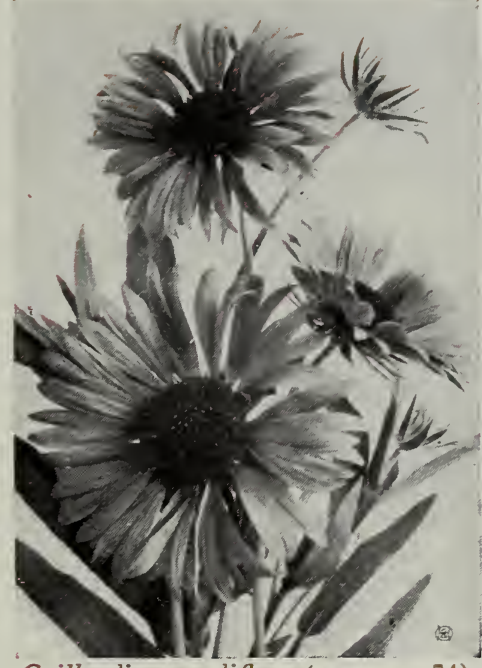

Gaillardia grandiflora (see page 54)

D. plumarius (Scotch Pink). Blooms all season. Height 8 to 12 inches. Colors mixed. Otherwise same as above. 15 cts.; strong, 25 cts.

Dianthus semperflorens (Everblooming Pink). Blooms all season. Height 8 to 12 inches. Colors mixed. 15 cts.; strong, 25 cts.

Dracocephalum Virginianum album (Dragon's Head). Terminal clusters of showy, pentstemonlike flowers. A cool situation is favorable to their growth. 2 feet. June and July.

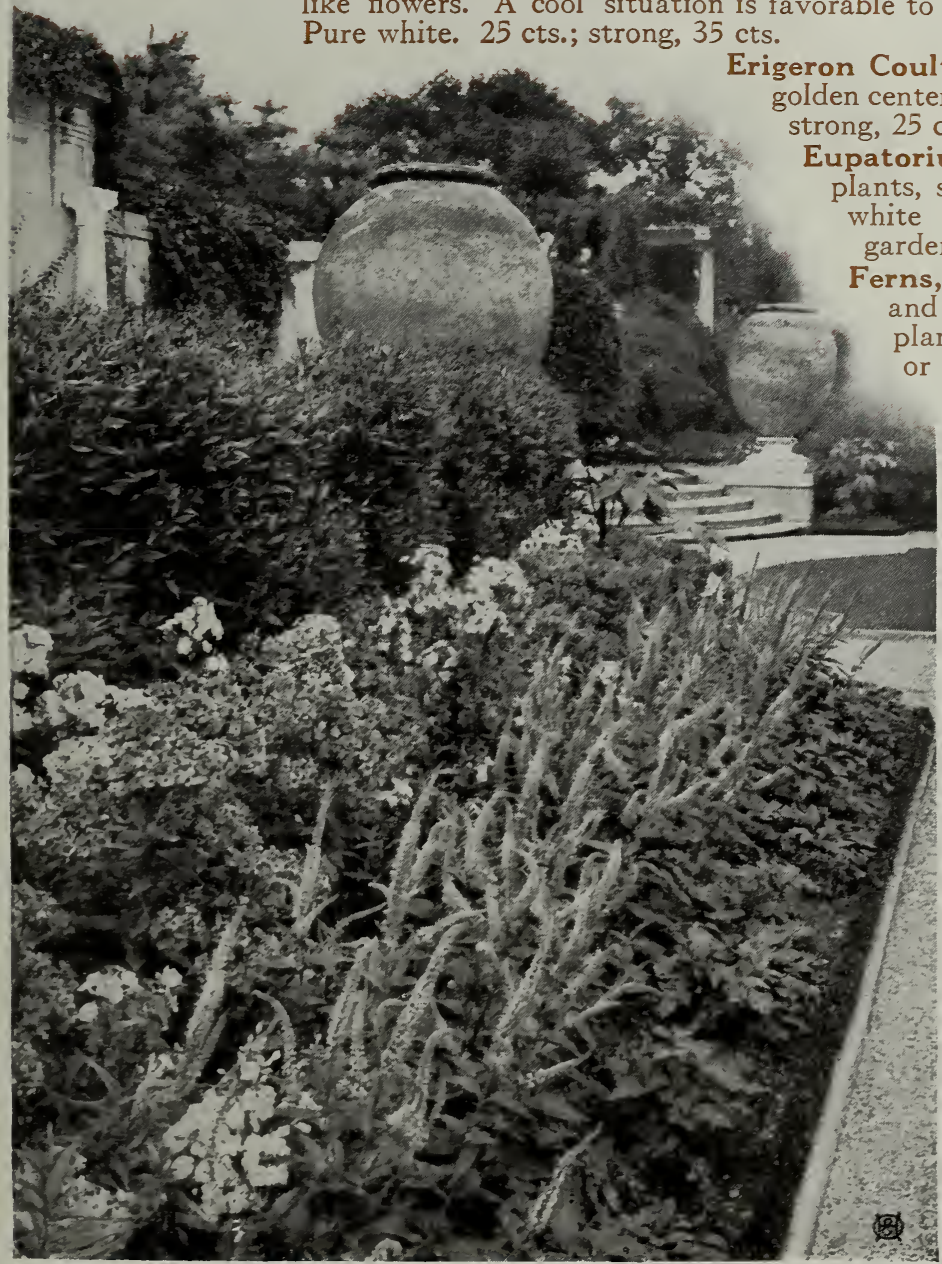

Veronica and Pblox make a cbarming combination of colors (see pages 57 and 62 ) 

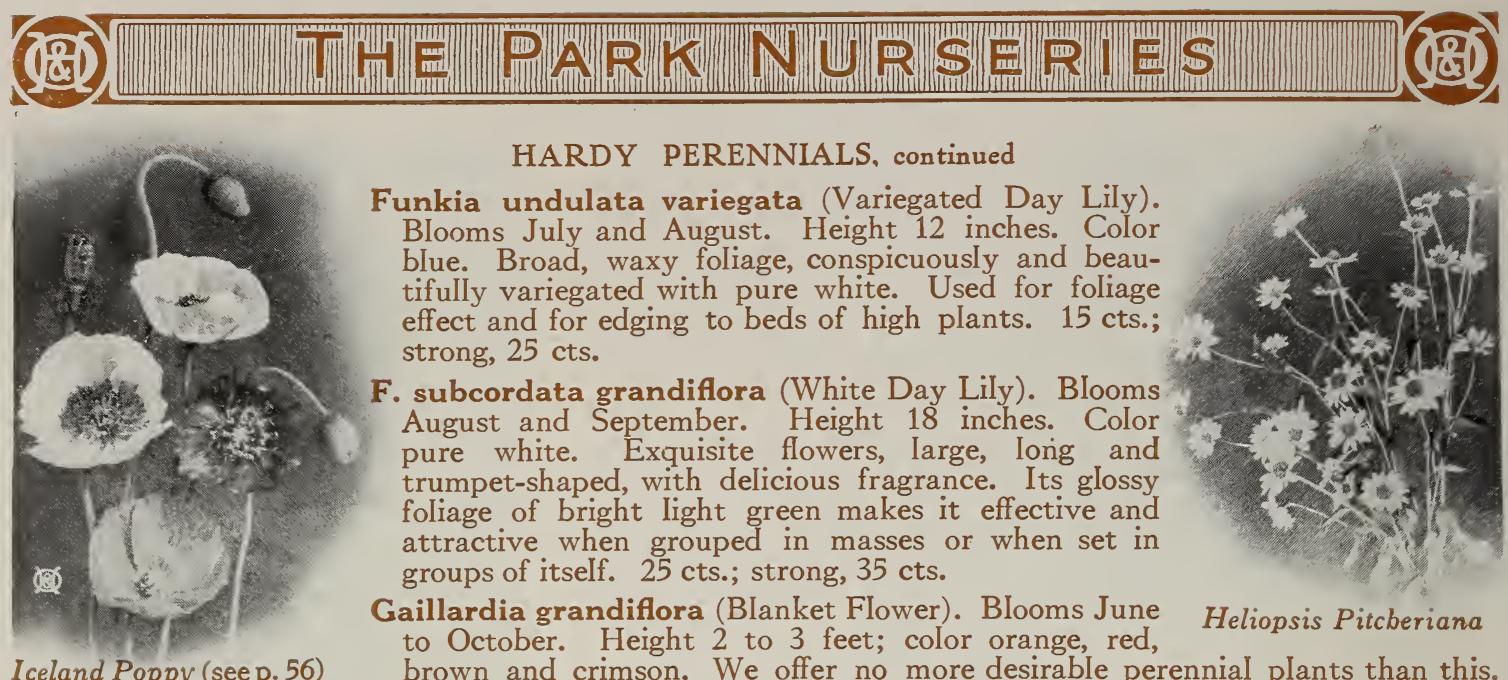

HARDY PERENNIALS, continued

Funkia undulata variegata (Variegated Day Lily). Blooms July and August. Height 12 inches. Color blue. Broad, waxy foliage, conspicuously and beautifully variegated with pure white. Used for foliage effect and for edging to beds of high plants. $15 \mathrm{cts}$; strong, 25 cts.

F. subcordata grandiflora (White Day Lily). Blooms August and September. Height 18 inches. Color pure white. Exquisite flowers, Iarge, Iong and trumpet-shaped, with delicious fragrance. Its glossy foliage of bright light green makes it effective and attractive when grouped in masses or when set in groups of itself. 25 cts.; strong, 35 cts.

Gaillardia grandiflora (Blanket Flower). Blooms June to October. Height 2 to 3 feet; color orange, red,

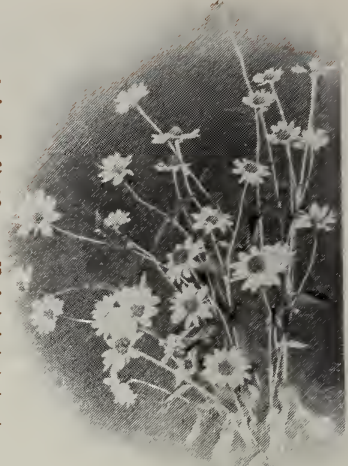

Heliopsis Pitcberiana

Iceland Poppy (see p. 56)

brown and crimson. We offer no more desirable perennial plants than this. It blooms the entire summer, and is' at home in all locations. Its flower is a bright golden yellow and rich reddish brown, going into all imaginable tints and shades. $15 \mathrm{cts}$; strong, 25 cts.

Golden Glow. See Rudbeckia.

Gypsophila paniculata (Baby's Breath). Blooms August to September. Height 3 feet. Color white. A favorite, delicately formed plant, that produces a profusion of tiny white flowers during the latter part of the summer. 15 cts.; strong, 25 cts.

G. paniculata fl. pl. The pretty, little, double, rosette-like flowers of this new variety, which are produced in much-branched panicles, are valuable for cutting and a most desirable addition to the hardy border. $25 \mathrm{cts}$.

G. rosea. A charming pink variety of Baby's Breath, with the same fairy-like grace of the white sort. 25 cts.; strong, 35 cts.

Hardy Pinks. See Dianthus.

Helenium (Sneezewort). All of these are desirable border plants, succeeding in any soil in a sunny location, with broad-spreading heads of flowers.

H. autumnale superbum. GoIden yellow flowers during the late summer and fall months. Height 5 to $6 \mathrm{ftt}$. 15 cts.; strong, 25 cts.

H. pumilum magnificum. A most useful perennial, about 18 inches high, and smothered with its golden yellow blossoms all summer. 15 cts.; strong, $25 \mathrm{cts}$.

Helianthus giganteus (Hardy Sunflower). A native variety, with medium-sized, bright canary-yellow flowers in September and October. Brightens the garden when colors are scarce, and the flowers are extra fine for home decoration. Height 6 feet. 15 cts.; strong, 25 cts.

H., Meteor. Large, double, orange-yellow flowers, with bold yellow guard petals; August and September. Height 5 feet. 15 cts.; strong, 25 cts.

H. multiflorus f. pl. (Double Hardy Sunflower). Large, double, dahlia-like, golden yellow flowers in great profusion during July and August. Especially fine for cutting, as they keep fresh a long time. Height 4 feet. 15 cts.; strong, 25 cts.

H. orgyalis. A tall variety, 6 feet high, with curious long, narrow foliage and bearing great clusters of medium-sized, single, golden yellow flowers during September.- Should always be planted in the back row of the border, and it is advisable to give the long stems some support. 15c.; strong, 25c.

H., Soleil d'Or. Deep golden yellow, quilled petals, not unlike a dahlia. One of the finest of all

Sunflowers to use for cutting, Iasting a long tim
August and September. 15 cts.; strong, 25 cts.

Heliopsis Pitcheriana (Orange Sunflower). Blooms June to September. Height 3 feet. Color orange. A continual bloomer from early summer until late in the season. The flowers are carried on long stems and are fine for cutting. Gives color to clumps of shrubbery or to perennial gardens. 15 cts.; strong, 25 cts.

H., Miss Mellish. September and October. Grows about 6 feet high; Iarge, single, golden yellow flowers, fine for cutting. 15 cts.; strong, 25 cts.

H. zinniæeflora. A new double-flowering form growing only 24 inches high and producing, in July and August, golden yellow flowers closely resembling a zinnia in form. Desirable for cutting. 25 cts.; strong, $35 \mathrm{cts}$.

Hemerocallis aurantiaca. One of the finest flowers whose color throughout June and July is a rich Indian yellow. Height 2 to 3 feet. 25c.; strong, 35c.

H. flava (Lemon Day Lily). Blooms during August and September. Height 3 feet. Color yellow. A profusion of Iarge, yellow lilies during the latter part of the summer gives color to clumps of shrubbery. 15 cts.; strong, 25 cts.

H., Florham. June and July; Iarge trumpet-shaped flower, rich golden yellow with Indian-yellow markings. Height 3 to $31 / 2$ feet. 25c.; strong, 35c.

H. Middendorfii. The earliest; flowers bell-shaped, rich chrome-yellow: Height 2 feet. Hardy and free-blooming. Early May. 15c.; strong, 25c. 


\section{(19iN) SAINT PAUL,MINN. (8)}

\section{HARDY PERENNIALS, continued}

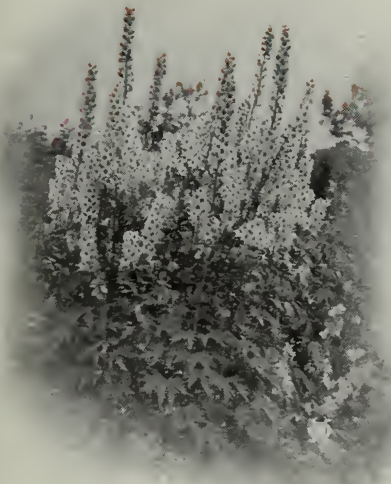

Delpbiniums (see page 52)
Hemerocallis Thunbergii. The latest to flower; rich buttercupyellow, funnel-shaped flowers throughout JuIy. Adds a distinctive touch of color to the garden. Height 4 feet. 15 cts.; strong, 25 cts.

Hibiscus, Crimson Eye (Marsh MaIIow). Blooms September to October. Height 4 feet. Color pure white, crimson center. A woody plant of rapid growth; likes moisture. In September it bears large flowers with crimson centers. 15 cts.; strong, 25 cts.

H. Moscheutos (Swamp Rose Mallow). Blooms September and October. Height 5 feet. Color pink. 15 cts.; strong, 25 cts.

H., Mallow Marvels. A robust type of upright habit; flowers of enormous size; rich shades of crimson, pink, and white. 25 cts.; strong, 35 cts.

Hollyhocks, Double (Althea). Blooms June to August. Height 4 to 5 feet. Colors mixed. Hollyhocks are undoubtedly among the most ornamental and handsome garden flowers, with their tall spikes dotted with large, double flowers of the most lovely shades of color. 20c.; strong, 25c.

H., Allegheny. Mammoth flowers, wonderfully formed of loosely arranged, fringed petaIs, which look as if made from the finest China silk. The colors vary from the palest shrimp-pink to deep red. The plants are of strong growth, sending up spikes 6 to 7 feet high. Mixed colors, also separate, in Pink, Yellow, Maroon and White. 20 cts.; strong, 25 cts.

H., Single. Many prefer the single-flowering Hollyhocks. They are usually of freer growth than the doubles, and present a very handsome appearance when covered with their artistic blossoms. Choicest mixed varieties in all colors. 20 cts.; strong, 25 cts.

Lilium speciosum album (Japanese Lily). Pure white, with beautiful recurved petals; very fragrant. 25 cts.; strong, 35 cts.; potted, 50c.

L. speciosum rubrum (Crimson-banded Lily). Once planted in a favorable location will last for years. Flowers are white, with a deep rosy crimson band on each petal; 5 to 6 inches in diameter. Are very fragrant and hardy. 25 cts.; strong, 35 cts.; potted, 50 cts.

Lilium tigrinum flore pleno (Double Tiger Lily). A double form of the well-known Tiger Lily; grows from 4 to 5 feet high, and produces a large number of bright orange flowers. 25 cts.; strong, 35 cts.; potted, 50 cts.

Linum perenne (Flax). Blooms all summer. Height 18 inches. Color blue. Graceful foliage, large blue flowers. A splendid plant for colony planting and with shrubbery. Most valuable in that it adds a much-needed touch of blue to the perennial border. 15 cts.; strong, 25 cts.

Lupinus polyphyllus (Lupine). These plants bloom from about the 20th of May for three weeks, and grow about 3 feet high, with handsome blue flowers. Perfectly hardy and free from attacks of insects. They require only well-prepared garden soil and to be kept watered. 15c.; strong, $25 \mathrm{c}$.
Incarvillea Delavayi (Hardy Gloxinia). One of the choicest perennial plants introduced in recent years. It produces large, gloxinia-like, rose-colored flowers, which last in perfection a long time; these are produced in clusters on stems 18 inches high; succeeds in sun or shade, but should be protected with a covering of leaves during the winter. 15 cts.; strong, 25 cts.

Iris. See page 61.

Lily-of-the-Valley (Convallaria majalis). Blooms May. Height 6 to 10 inches, Heavy dark green foliage, with smaIl, bell-shaped, pure white flowers in pretty racemes, graceful and extremely fragrant. Requires rich, moist soil. Succeeds best in partial shade. 15 cts.; strong, 25 cts.

Lilium auratum (Gold-banded Lily). Blooms July. Height 3 feet. Color ivory-white, thickly marked with reddish chocolate dots. Immense, bell-shaped flowers borne in clusters on long, stiff stalks. The most beautiful and popular variety of aII the Lily family and should be in every garden. 25 cts.; strong, 35 cts.; potted, 50 cts.

L. elegans (Orange Lily). Of dwarf habit; very hardy and produces large, showy flowers in great numbers. They range in color from orange to dark red, some being apricot-yellow, aII being beautifully dotted more or less with dark brown. $20 \mathrm{c}$; strong, $35 \mathrm{c}$.
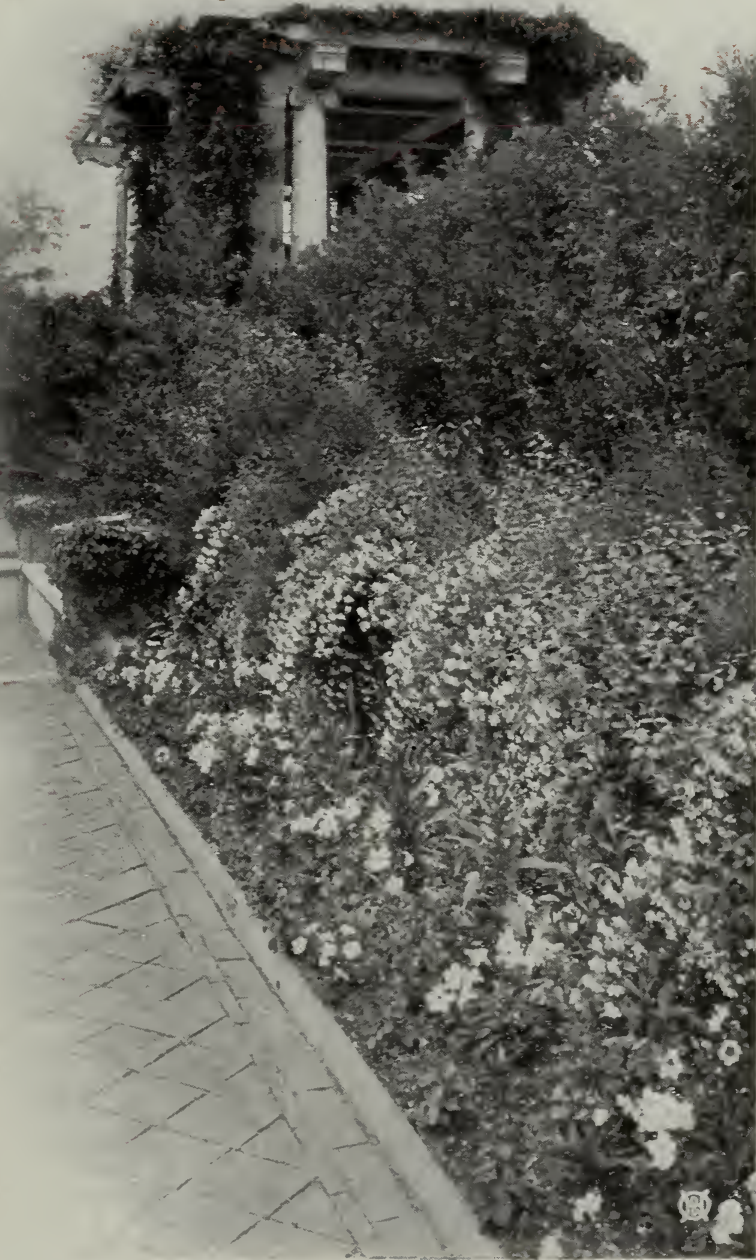

Perennials and Sbrubbery make a charming combination 


\section{(1960) THE PARK NURSERIES (186)}

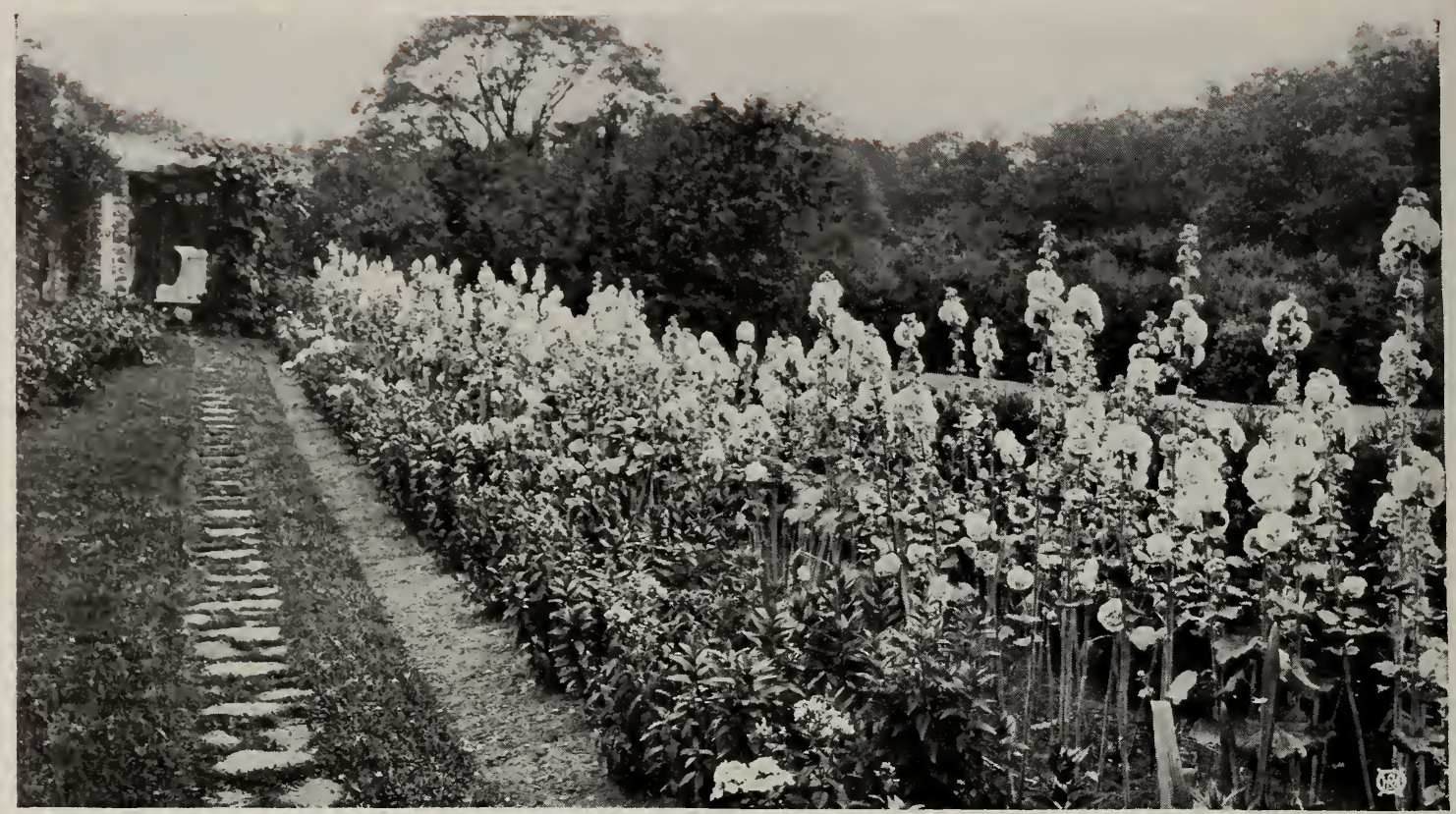

There is sometbing impressive about a stately row of Hollybocks (see page 55)

\section{HARDY PERENNIALS, continued}

Lychnis Chalcedonica (London Pride). Blooms JuIy to September. Height 3 feet. Color orangescarlet. Is an especially desirable perennial, with brilliant heads of flowers. 15 cts.; strong, 25 cts.

L. Haageana. A very showy perennial, remarkable for its striking flowers, nearly 2 inches across, of brilliant scarlet; hardy and easily grown. Height 1 foot. July and August. 15 cts.; strong, 25 cts.

Lythrum roseum superbum (Loosestrife). A vigorous perennial, with spikes of bright rosecolored flowers, thriving best in a damp situation; useful for cutting. Height 4 feet. July to September. 15 cts.; strong, 25 cts.

Mentha spicata (Spearmint). This is the hardy Spearmint, used largely for seasoning and making sauce. 15 cts.; strong, 25 cts.

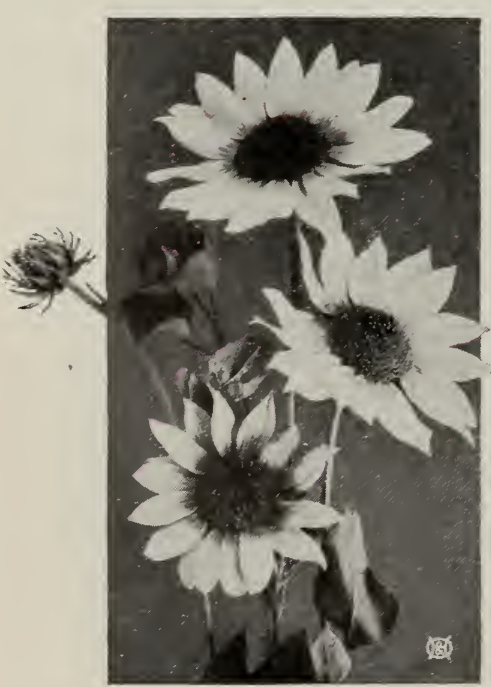

Hardy Sunflowers (see page 54)

Monarda didyma (Oswego Tea). Great clusters of brilliant scarlet flowers. 3 feet. June to September. 15 cts.; strong, 25 cts.

M., Cambridge Scarlet. Brilliant crimson-scarlet. July and August. 15 cts.; strong, 25 cts.

Myosotis palustris semperflorens (Forget-menot). Clusters of dainty blue flowers; useful in a shady border and for forcing. 15c.; strong, 25 cts.

Pachysandra terminalis. A trailing plant 6 to 8 inches high, forming broad mats of bright glossy green foliage and small spikes of flowers during May and June. 20 cts.; strong, 25 cts.

Peonies. See page 58.

Papaver orientale (Oriental Poppy). Blooms June and JuIy. Height 2 to 3 feet. Scarlet flowers with a center spot as black as night upon which the light changes color all the time. 15 cts.; strong, 25 cts.

Papaver nudicaule (Iceland Poppy). Blooms June and September. Height 12 inches. Colors mixed. The cup-shaped flowers vary in color from pure white to deep orange. $15 \mathrm{cts}$; strong, $25 \mathrm{cts}$.

Pentstemon barbatus Torreyi (Beard Tongue). A stately, brilliantflowering perennial, with long, loose panicles of bright scarlet flowers. 4 feet. July. 15 cts.; strong, 25 cts.

Phalaris arundinacea variegata (Ribbon Grass). Large, variegated foliage; valuable for bouquets and for edging large beds. 15 cts.; strong, 25c.

Phlox. See page 62.

Physostegia Virginica (False Dragon-Head). Grows into a dense bush, covered with heath-like, pink, tubular flowers. Showy and reliablè as a garden plant. 1 to 3 feet. JuIy and August. 15 cts.; strong, 25 cts.

P. alba. A fine pure white variety of the above. $15 \mathrm{cts}$; strong, $25 \mathrm{cts}$.

P. rubra. Beautiful soft pink flowers in spikes. 15 cts.; strong, 25 cts.

P. speciosa. A tall form, with bright pink, showy flowers. 2 feet. June. 15 cts.; strong, 25 cts.

Platycodon album (Japanese Bellflower). Blooms June to September. Height 18 inches. Color white. 15 cts.; strong, 25 cts.

P. grandiflorum. Deep blue, cupped, star-shaped flowers. 15c.; strong, 25c.

P. Mariesi. Blooms June to September. Height 18 inches. Color blue. Similar to Grandiflorum but the flowers are deeper blue. 15c.; strong, 25c.

Polygonum cuspidatum (Knotweed). August and September. A vigorousgrowing plant, 6 inches in height, with large, heart-shaped foliage and innumerable racemes of white flowers. Very useful for the wild garden, shrubbery borders, or for isolated positions on the Iawn. 15c.; strong, 25c. 
HARDY PERENNIALS, continued

Pyrethrum roseum (Feverfew). Very beautiful, double flowers that range in color from pure white and the various shades of pink and red to deep purple. Main season of blooming is in June, but will flower again later. 15 cts.; strong, 25 cts.

P. uliginosum (Great Ox-eye Daisy). Stout, upright plants 4 to 5 feet high, with beautiful fern-like foliage; large flowers, 2 to 3 inches across, white with bright yellow center; long stems which are splendid for cutting purposes; very choice. August to October. 15 cts.; strong, 25 cts.

Ranunculus repens (Buttercup). June and July. A very freegrowing creeper, with double yellow flowers; foliage coarsely cut. 15 cts.; strong, 25 cts.

Rudbeckia laciniata (Golden Glow). Blooms July and August. Height 5 to 6 feet. Color yellow. Its tall, swaying stems are aglow with golden yellow, dahlia-like flowers; used for background in borders and with shrubbery. 15 cts.; strong, 25 cts.

R. maxima. A rare and attractive variety, growing 5 feet high, with large, glaucous green leaves and bright yellow flowers 5 to 6 inches across, with a cone 2 inches high; flowers continuously from June to September. 25 cts.; strong, 35 cts.

R. Newmanii. Dark orange-yellow flowers, with deep purple cone, borne on stiff, wiry stems 3 feet high; flowers from July to October. 15 cts.; strong, 25 cts.

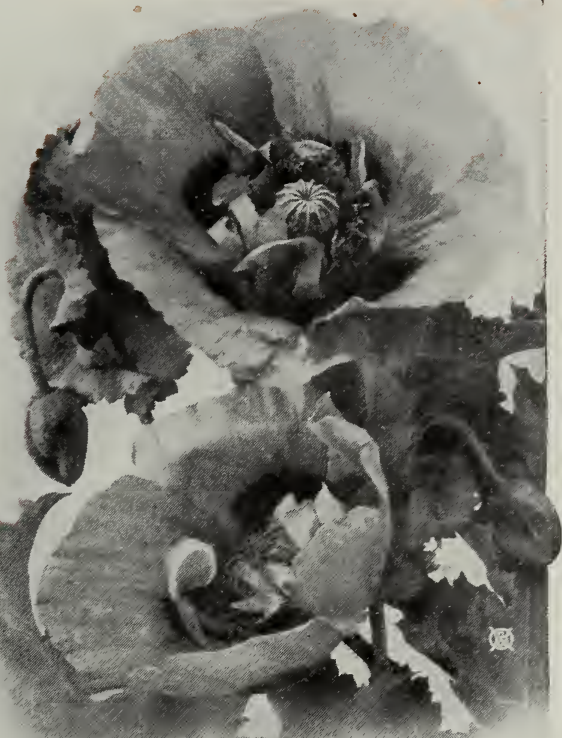

Poppies are always sbowy (see page 56)

R. triloba. Forms much-branched plants, 3 feet high, with masses of medium-sized yellow flowers with brown disc, during August and September. 15 cts.; strong, 25 cts.

Salvia Pitcheri. The flower is a sky-blue, blooms in great profusion in September and is very attractive. Height 3 to 4 feet. 25 cts.; strong, 35 cts.

Sedum spectabile (Brilliant Stonecrop). Blooms July and August. Height 18 inches. Color rose. Of erect habit and the frnest of the Sedums; large, oval, light green leaves and flat terminal cluster of rose-colored flowers. 15 cts.; strong, 25 cts.

S. acre (Golden Mass). Blooms June and JuIy. Height 4 inches. Color golden. A low carpet plant, splendid for rockeries, wall gardens, edgings or covering graves. 15 cts.; strong, 25 cts.

Shasta Daisy. See Chrysanthemum, page 51.

Stokesia cyanea (Cornflower Aster). Blooms July and August. Height 18 inches. Color deep blue. A desirable perennial, producing a succession of large, double, blue flowers. 15 cts.; strong, 25 cts.

Statice latifolia (Sea Lavender). The minute bright blue flowers are produced in broad heads and are adapted for cutting, as they keep Iong after being dried, and are very showy. 1 to 2 feet. July to September. 15 cts.; strong, 25 cts.

Spiræa Filipendula fl. pl. (Double-flowered Meadow Sweet). Numerous corymbs of double white flowers, on stems 12 inches high, during June and July, and pretty fern-like foliage. $15 \mathrm{cts}$; strong, 25 cts.

S. Japonica. Large panicles of white, feathery flowers in June; 2 feet. 15 cts.; strong, 25 cts.

S. palmata (Crimson Meadow Sweet). One of the most beautiful hardy plants, the deep purple-red of the stems and branches passing into the crimson-purple of the broad corymbs of flowers, which are produced very freely during June and July; 3 feet. 15 cts.; strong, 25 cts.

S. elegans. A free-flowering, silvery pink form of the above. 15 cts.; strong, 25 cts.

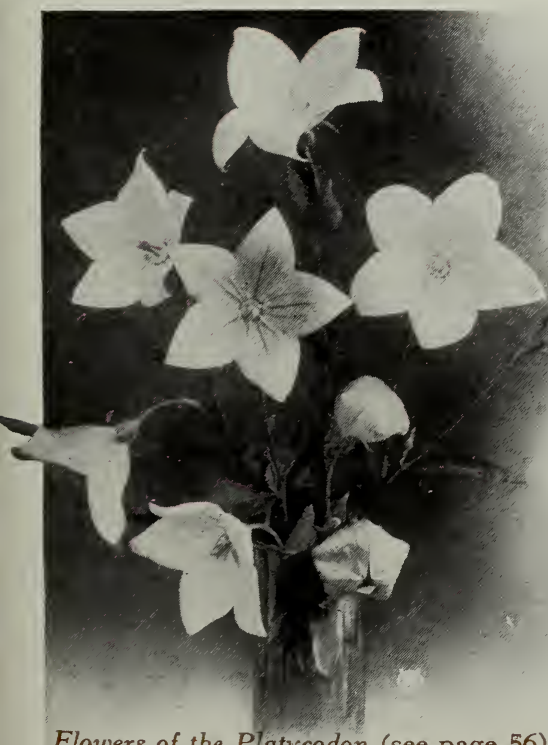

Flowers of the Platycodon (see page 56)

Valeriana officinalis (Hardy Garden Heliotrope). Produces showy rose-pink heads of flowers during June and July, with strong heliotrope fragrance. 15 cts.; strong, 25 cts.

Veronica spicata (SpeedweII). Height 18 inches. Color blue. Blooms continuously throughout the summer and is very attractive. Produces its flowers on long spikes. $15 \mathrm{cts}$.; strong, $25 \mathrm{cts}$.

V. Virginica. Tall-growing, with Iarge and noticeably distinct spikes of white flowers. 5 feet. August. 15 cts. each; strong, 25 cts.

Viola (Violets). Many of the hardy forms of this dwarf species are

reasily grown, and should be more generally cultivated.

V. cornuta. 9 in. April to August. Dark purple. 15 cts.

V. cornuta alba. 6 in. April and May. Large, white-flowered variety and constant bloomer. Useful as a border plant. $15 \mathrm{cts}$

V. cornuta Papilio. Very large flowers, violet in color, with dark eye. 15 cts.

V., Hardy Russian. A robust-growing variety with Iarge, single, fragrant, deep blue flowers. One of the finest hardy varieties. 15 cts.; strong, 25 cts.

Yucca filamentosa (Adam's Needle). Blooms June and July. Height 4 feet. Color white. A charming plant to group in the hardy flower-border or as a specimen in the Iawn. The tall spikes of bell-shaped flowers and the long, narrow leaves, edged with thread-like hair, are without an equal. $25 \mathrm{cts}$; strong, $50 \mathrm{cts}$. 


\section{PEONIES}

VER popular in our
grandmother's garden
as the "Piney." Today, with hundreds of improved sorts, the Peony rivals the rose in brilliant coloring, sweet fragrance, and perfection of flower. It is adapted to almost any garden soil and is extremely hardy in the Northwest. Flowers are larger than those of any other perennial, and are borne on stiff, strong stems.

Once planted, all is done; nothing more is required beyond a liberal dressing of manure every fall, and each succeeding year adds to the size and beauty of the flowers.

Consider these features: The Peony is as hardy as the oak, absolutely free from disease of every kind, and entirely free from insects and pests of any sort. No dusting, spraying or hand-picking of worms. No roots to take up each faII, as with the dahlia.

How to Prepare the Soil.-Peonies, like most plants in beds, soon exhaust the soil and require feeding. The best preparation for their planting is to remove the good top-earth, and put it aside; then replace 12 to 15 inches of the bottom-soil with wellrotted manure, and fill up with the top-soil. If possible, the bed should be prepared at least a month before it is planted.

When to Plant.-Plant Peonies in September or October, to bloom the following June. Planting can be done in April and May but little bloom can be had the first year. The plants should be set with the eyes 2 to 3 inches below the surface of the ground, pressing the soil tightly about the roots. Place the clumps about 3 feet apart.

\section{WHITE}

Alba sulphurea. Large, creamy white bomb, very massive. One of the best whites of the bomb type. Superior to one often sold under this name. Divided roots, 50 cts. each; clumps, $\$ 1$ to $\$ 1.50$.

Couronne d'Or. Large blooms of ivory-white, with a circle of yellow which suggests the name; an extra-fine sort. Blooms rather late. 75 cts. each; clumps, $\$ 1.50$ to $\$ 2$.

Duchesse de Nemours. Here is a variety of unique beauty. The guard petals are extra large, the center is fulI; the color is the clearest transparent white, without red markings; the fragrance is unusually dainty. 75 cts. each; clumps, $\$ 1.50$ to $\$ 2$.

Festiva. Late midseason. Fine, very full, shellformed bloom on strong stems; color fine ivorywhite, with a few carmine spots on the center petals; very fragrant. One of the best cut-flower sorts. 50 cts. each; clumps, $\$ 1$ to $\$ 2$.

Festiva maxima. Probably the greatest Peony ever grown. For fifty years it has held first rank and is still the standard of perfection by which all other Peonies are judged. The immense blooms, 7 or 8 inches in diameter, are borne over 40 inches above the ground on strong stems, and are of the purest paper-white, accentuated by an occasional flake of red in the center. One of
Festiva maxima, continued

the very earliest to bloom, and extremely fragrant. 75 cts. each; clumps, $\$ 1.50$ to $\$ 3$.

Golden Harvest. An American variety comparing favorably with the best from Europe. Not very tall, but is large and one of the freest bloomers in the lot; color, blush white with creamy white guard, center carmine-tipped in most pleasing combination; midseason blooming period. $50 \mathrm{cts}$. each; clumps, $\$ 1.50$ to $\$ 2$.

Jeanne d'Arc. Soft pink; center sulphur-white. Very fragrant. This is one of the most desirable of the light-colored Peonies, being very free and a vigorous grower. Similar to but better than Golden Harvest. 50 cts. each; clumps, $\$ 1$ to $\$ 2$.

La Tulipe. Very large, shell-formed bloom; delicate rose, fading to creamy white; center petals tipped with carmine; outside of guard petals striped with carmine. Late. 75 cts. each; clumps, $\$ 1.50$ to $\$ 2$.

Madame Calot. Pinkish white, tinted with fleshcolor. Extra-fine variety. 75 cts. each; clumps, $\$ 1.50$ to $\$ 2$.

Madame Crousse. Very Iarge, full, well-made flower; color snow-white, center petals edged with bright carmine. Extra fine for all purposes. Taken all together, this is, in our estimation, the best of all the white Peonies. 75 cts. each; clumps, $\$ 1.50$ to $\$ 2$. 


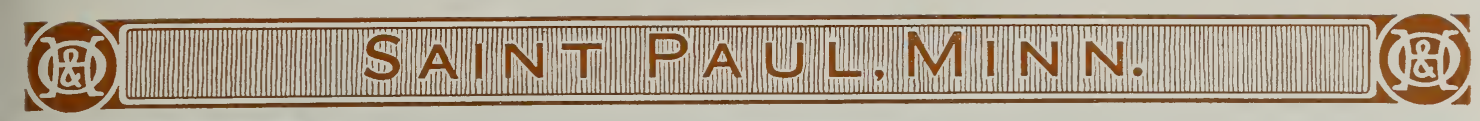

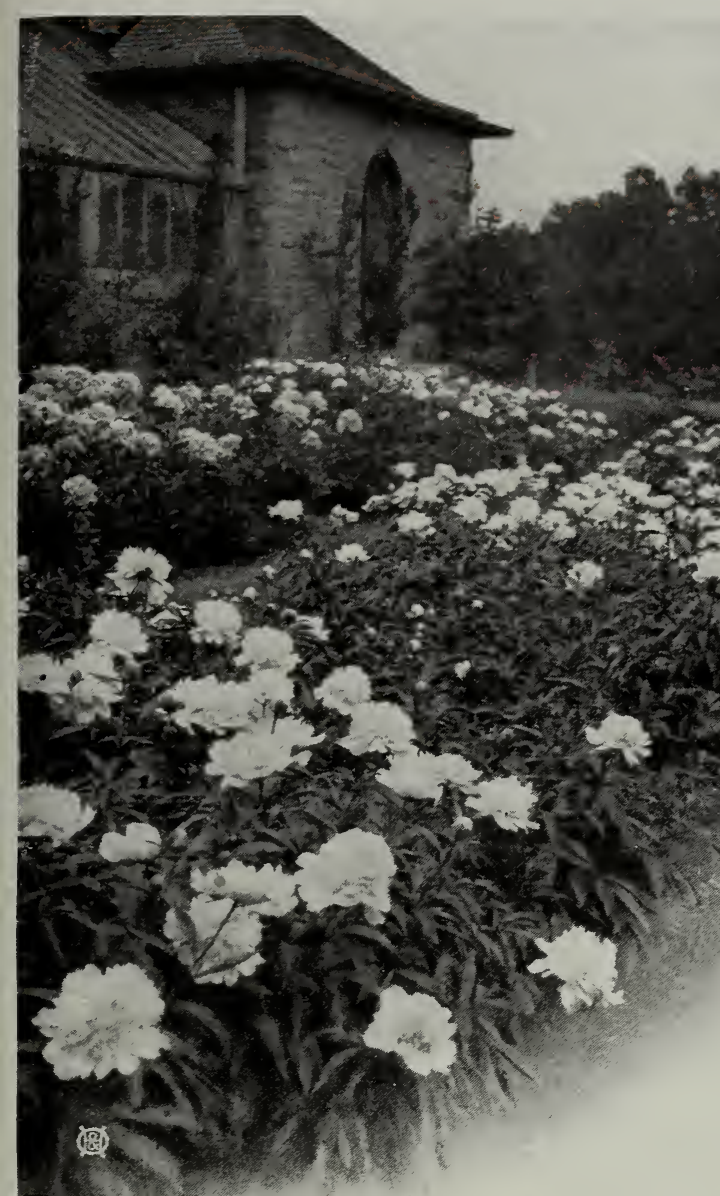

The regal beauty of the Peony is enbanced by planting in large beds

\section{WHITE PEONIES, continued}

Madame de Verneville. One of the most charming varieties on the market. The guard petals are pure white, very large and folding ove flower; balance is suffused with daintiest blush except a few cream-colored petals and four red flakes in center, the total being an exceptionally beautiful flower. Has a more delightfully delicate fragrance than any other. Always blooms early and very freely. One of the absolutely indispensable varieties. $\$ 1$ each; clumps, $\$ 2$ to $\$ 3$.

Marie Lemoine. A valuable sort because the latest white to bloom, thus extending the season after earlier ones are passed. It has immense creamy or ivory-white blooms, with an occasional carmine tip on center petals. Very stiff stems. 75 cts. each; clumps, $\$ 1.50$ to $\$ 2.50$.

M. Dupont. One of the best Iate white sorts. Flowers very large, cup-shaped, on stiff stems. Clear ivory-white, with brilliant carmine border on center petals. Pleasant fragrance. A good grower and free-bloomer. 75 cts. each; clumps, $\$ 1.50$ to $\$ 2.50$.

Queen Victoria. The oldest double white Peony, consequently low-priced. A large, fuII flower of good substance and color, keeping best of all when cut. Very pretty in bud, when it has a faint blush-tint. Very thrifty in growth. $50 \mathrm{cts}$. each; clumps, $\$ 1.50$ to $\$ 2$.

\section{PINK PEONIES}

Alexander Dumas. Brilliant pink, interspersed with white and salmon. Very early and free. One of the best for cut-flowers. 50 cts. each; clumps, $\$ 1.50$ to $\$ 2$.

Albert Crousse. Is colored and formed, with imbricated petals, like a big, flesh-pink carnation. Unusual shade for a Peony. \$2 each; clumps, $\$ 3.50$ to $\$ 5$.

Baroness Schroeder. A most delicate, light flesh-pink bud, bleaching when open to white; extra large and massive. The true stock is very scarce and in great demand by those who have ever seen it. The best of the English varieties. \$3 each; clumps, $\$ 4$ to $\$ 6$.

Delicatissima. Large flower of very delicate, clear pink. Fine buds and strong stem; fragrant, free and early. One of the best and most popular pinks, either for cut-flower market purposes or for private enjoyment. 75 cts. each; clumps, $\$ 1.50$ to $\$ 2$.

Edulis superba. Soft pink, very early. Large guard. 50 cts. each; clumps, $\$ 1.50$ to $\$ 2$.

Faust. A delicate flesh, with a darker center. Very pretty; late midseason. 50 cts. each; clumps, $\$ 1.50$ to $\$ 2$.

Fragrans. One of the oldest, most sweet-smelling of the bright deep pinks, earliest to bloom and in every way one very satisfactory. 50 cts. each; clumps, $\$ 1.50$ to $\$ 2$.

Lady Leonora Bramwell. Beautiful, Iarge, rosecolored Peony. Very free. Splendid cut-flower sort. 50 cts. each; clumps, $\$ 1.50$ to $\$ 2$.

Livingstone. Pale rose, beautiful shadings with some carmine; would be considered a rose type. Blooms late, quite taII, on very strong stems. One of the best. 75 cts. each; clumps, $\$ 1.50$ to $\$ 2.50$.

Madame Boulanger. Light silvery pink, with flesh guard; regular and solid; rose shape; very large; exceedingly fragrant; Iate. One of the best pinks. 75 cts. each; clumps, $\$ 1.50$ to $\$ 2.50$.

Madame Camille Bancel. One of the fine new sorts. Rich deep pink, lighter toward the center; very massive rose shape. \$1 each; clumps, $\$ 2.50$ to $\$ 4$.

Pottsii alba. Said by some to be identical with Eugene Verdier. One of the showiest and most beautiful baby-pink varieties in existence. Very large, 40 inches taIl, very free bloomer, and of a most delicate pale flesh-pink, which sometimes fades to nearly white. $\$ 1$ ea.; clumps, $\$ 2.50$ to $\$ 4$.

Pulcherrima. Outside petals flesh, center pink. Very large, and borne on long, strong stems. 50 cts. each; clumps, $\$ 1.50$ to $\$ 2$.

\section{RED PEONIES}

Auguste Villaume. Immense bloom of American Beauty shade. Great for exhibition purposes. 75 cts. each; clumps, $\$ 2$ to $\$ 3$.

Delachei. Deep rich crimson-maroon with velvety sheen. One of the best dark reds. Dark, glossy foliage. 50 cts. each; clumps, $\$ 1.50$ to $\$ 2$. 


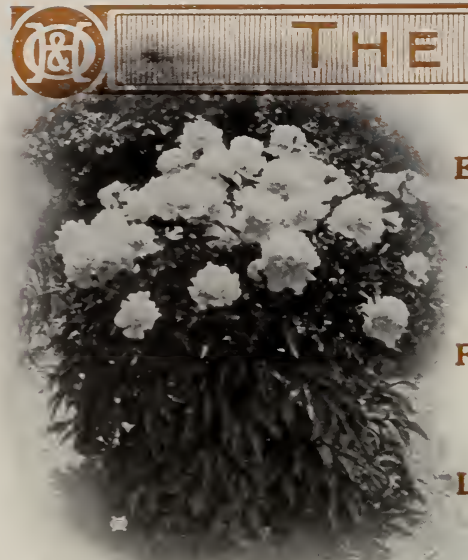

A typical Peony plant

\section{RED PEONIES, continued}

Edouard Andre. Large, globular bloom; deep crimson with metallic Iuster on the reflex of the petals; striking color; strong grower. Divided roots. 75 cts. each; clumps, $\$ 2$ to $\$ 3$.

Felix Crousse. Bright red bomb, distinct color, very large and massive; very free, grand in every way. $75 \mathrm{c}$. each; clumps, $\$ 2$ to $\$ 3$.

Lee's Grandiflora rubra. Rich red, resembling an American Beauty rose; of enormous size and long stem. One of the latest and best. 50 cts. each; clumps, $\$ 1.50$ to $\$ 2$.

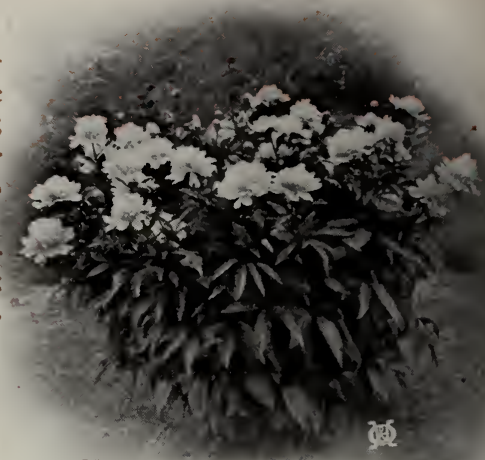

The way our Peonies grow

Louis Van Houtte. Velvety purple; very dark color and fine form. Plant vigorous in growth, with frne foliage. 50 cts. each; clumps, $\$ 1.50$ to $\$ 2$.

Madame Bucquet. Very dark maroon-purple, beautiful bud, large bloom; very free bloomer. The best dark red or "black," with stamens. All who see it insist on having it. 50 cts. each; clumps, $\$ 1.50$ to $\$ 2$.

Madame Mechin. Dark red, with stamens. A fine variety for lawn or private garden. 75 cts. each; clumps, $\$ 2$ to $\$ 3$.

Officinalis rubra. This is the old-fashioned red, the most brilliant of all red Peonies. Early and splendid cut-flower. 50 cts. each; clumps, $\$ 1.50$ to $\$ 2$.

Richardson's Rubra superba. Rich, deep crimson; Iatest of all. Very sweet. 75 cts. each; clumps, $\$ 2$ to $\$ 3$.

Rubra triumphans. Brilliant crimson, showing bright yellow stamens; very large; early. 75 cts. each; clumps, $\$ 1.50$ to $\$ 2$.

Tenuifolia. Flowers double; brilliant crimson; frne, feathery foliage; very early. 50 cts. each; clumps, $\$ 1.50$ to $\$ 2$.

\section{UNNAMED PEONIES}

These can be supplied in colors, and contain many of the best sorts. Having lost the stakes and names makes it necessary to sell by colors only. These are all fine, vigorous roots, and will produce splendid plants and handsome flowers. Some of the best named sorts are in this mixture; if we were sure of the name, you could not buy them at this price. $25 ; 35$ and 50 cts. each.

\section{JAPAN TREE PEONIES}

The Tree Peonies grow in the form of a dwarf shrub, very free-flowering, blooming earlier than the herbaceous sorts, and while also perfectly hardy it is best to give them some protection, as they do not die down to the ground in winter. The flowers are very large, from 8 to 12 inches in diameter, and are of richest and most delicate shades. Order by colors, as the Japanese names do not look good in print. $\$ 1.50$ each, $\$ 12.50$ for 10 .

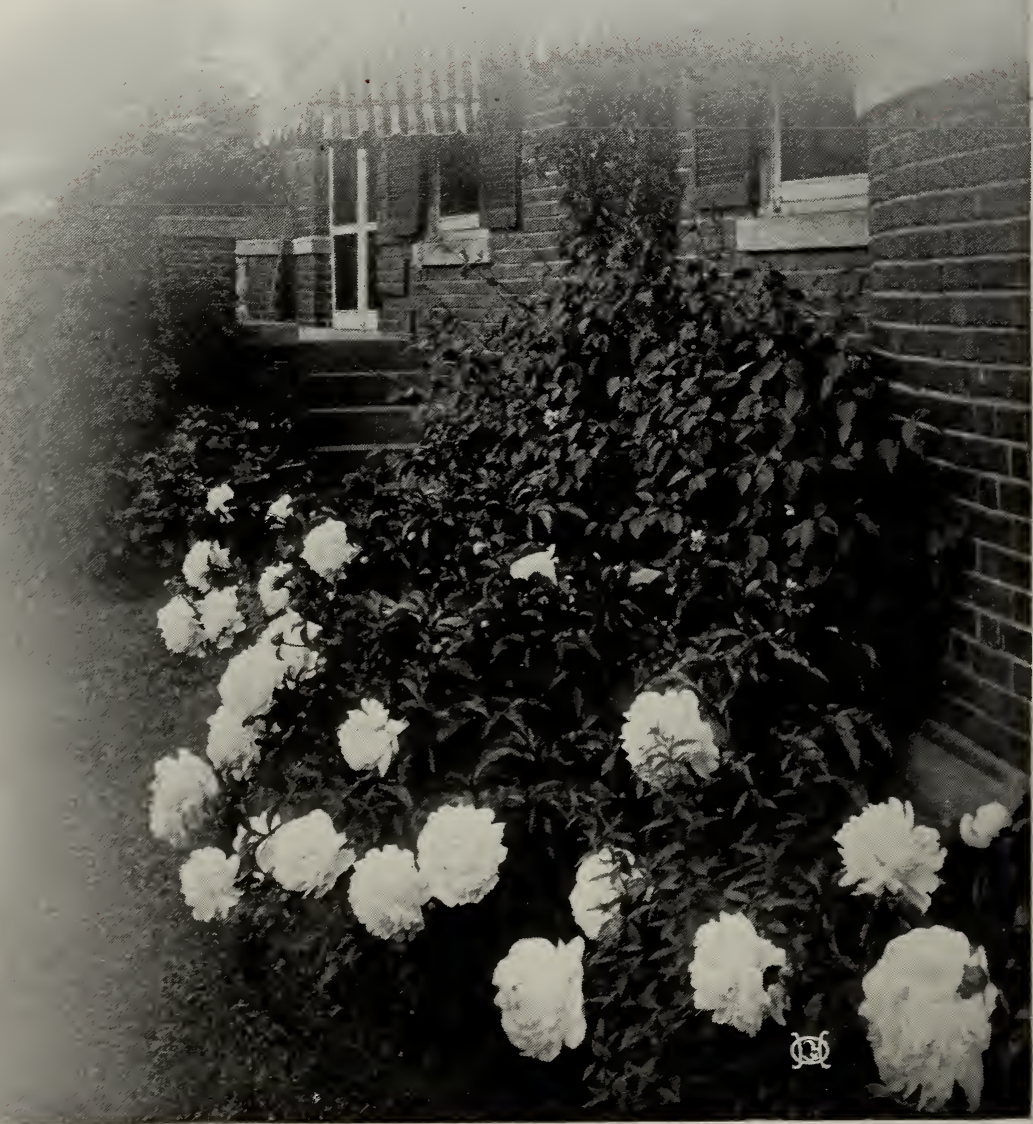

Peonies grouped with sbrubs are always attractive when in bloom 


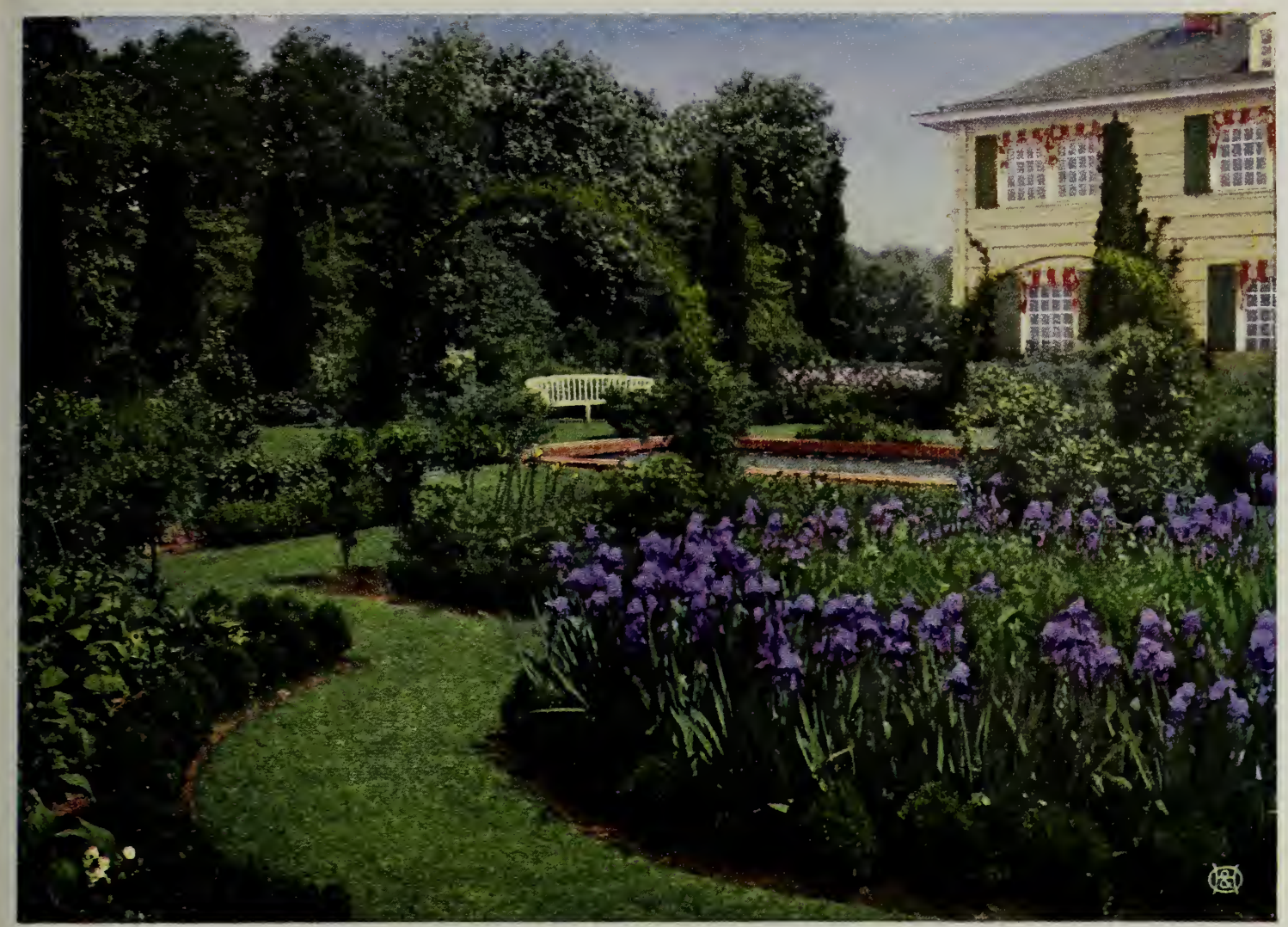

The delicate texture and beauty of the Irises have won for them the title of "The Orchids of the Garden." Whetber planted in solid masses, or in small groups among the sbrubs, they command instant attention

\section{IRIS}

TO garden is complete without a good selection of these lovely flowers. So many places are found where they can be used, and they are always attractive and welcome, blooming in early summer, before most of the shrubs. A good border flower for planting along paths, for grouping in beds along foundations or lawn walks, and very striking near rustic work, or in Japanese gardens. You can have blossoms from May until July, by selecting early and Iate sorts.

\section{GERMAN IRIS}

Aurea. Pure chrome-yellow. 15 cts.; strong, 25 cts. Bridesmaid. Standards white, shaded silvery lilac; falls slightly frilled, soft lilac. 15 cts.; strong, 25 cts.

Darius. Standards Iemon-yellow; falls purple, shading to pale yellow; large. $15 \mathrm{c}$.; strong, $25 \mathrm{c}$.

Edith. Standards light plumbago-blue; falls purple. 15 cts.; strong, 25 cts.

Fairy. Standards ivory, changing to white; falls white with pale violet veining. $25 \mathrm{c}$.; strong, $50 \mathrm{c}$.

Florentina. Standards and falls white, with faint lavender tint; Iarge and fragrant. 15c.; strong, 25c.

Her Majesty. Standards Iilac-pink; falls deep reddish lilac, with dark veinings. 35c.; strong, 50c.

Julius Cæsar. Standards amber; falls deep purple. 15 cts.; strong, 25 cts.

Madame Chereau. Standards and falls white, frilled violet. 25 cts.; strong, 35 cts.

Pallida Dalmatica. Strong, vigorous habit; Iarge flowers; Iavender, shaded blue. 35c.; strong, $50 \mathrm{c}$.

Penelope. Standards white, speckled violet; falls white, veined reddish violet. 15 cts.; strong, 25c.

Sappho. Standards deep violet-blue; falls dark, velvety, royal purple. 35 cts.; strong, 50 cts.

Speciosa. Standards lavender-purple; falls dark reddish purple. 25 cts.; strong, 35 cts.

Unnamed Varieties, All Shades. 15 cts., \$8 per 100 ; strong, 25 cts.

\section{JAPANESE IRIS (Iris Kaempferi)}

Commence blooming about the middle of June, and continue for five or six weeks. Many of the flowers measure from 10 to 12 inches in diameter, and rival the orchids in their rich colorings.

Blue Jay. Fine azure-blue, freely mottled. $35 \mathrm{cts}$; strong, 50 cts.

Eclaire. Largest white. 35 cts.; strong, 50 cts.

Mt. Hood. Light blue, shaded darker. 35 cts.; strong, 50 cts.

Paragon. Rich, velvety purple, center marked with orange. 35 cts.; strong, 50 cts.

Sakata. Lavender-blue, with deeper veinings; minor petals ageratum-blue. 35 cts.; strong, 50c. Spotted Beauty. Large size, double; silky white. 35 cts.; strong, 50 cts.

Victor. Violet-purple, with white veins. 35 cts.; strong, 50 cts.

\section{SIBERIAN IRIS}

Blue. Flowers similar to the German Iris. Clear, rich blue, but smaller; borne on Iong, slender stems in great profusion. Strong growers. 15 cts.; strong, 25 cts.

White. A fine, pure white form. $15 \mathrm{cts}$.

Snow Queen. Large, snow-white flowers carried on strong stems. An acquisition for our northern climate. Free bloomer. June. 25 cts.; strong, 35c. 


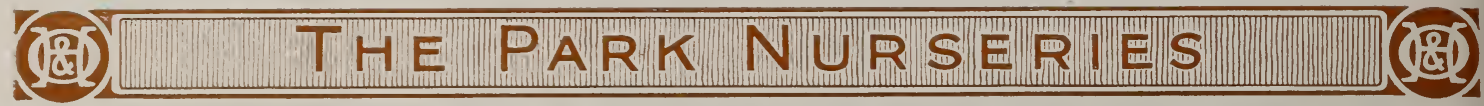

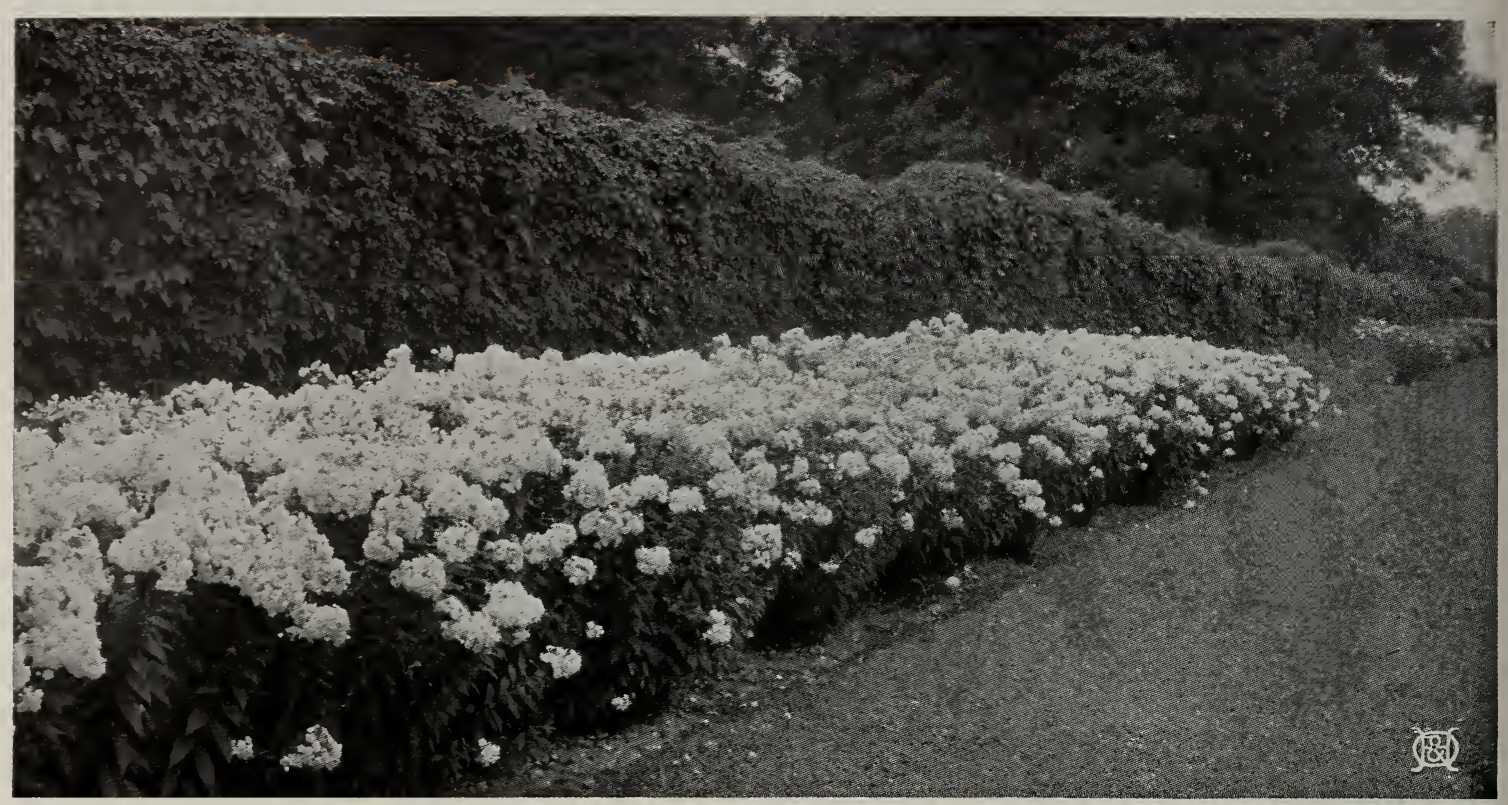

The great trusses of the Pblox bend and sway in summer breezes

\section{HARDY PHLOX}

$\mathrm{T}$

HE FINEST and most useful of the herbaceous plants. They succeed in almost any soil, or in any position, and flower throughout a Iong season. The plants remain in good condition for many years without attention, other than cultivating, and respond rapidly to improved cultivation and care. By a careful selection of the early and late varieties, and by cutting off the flower-heads as soon as the blossoms fade, it is possible to have Phlox in bloom from June until late fall.

Planting.-Phlox may be planted in the autumn, from the 1st to the 15th of October, so as to become established before winter; but when they are to be planted in conjunction with other perennials, wait until spring. Plant early, for Phlox puts out new growth as soon as the frost leaves the ground. Always mulch with well-rotted manure; this will be beneficial to the plants, both summer and winter.

The ground where Phlox is to be planted should be trenched a foot or more in depth, and a layer of welldecomposed manure placed in the bottom of the trench, which should then be filled very full with alternate Iayers of a few inches each of good top soil and manure. Whether planted in spring or fall, a mulch of old manure thrown around the roots will be of benefit to the plants. PhIox should be set out 18 inches apart, and if kept well watered will produce both individual blossoms and heads of bloom far larger than otherwise, and amply repay the extra trouble. It is a good plan to divide the clumps every three or four years, as overcrowding tends to reduce the size of the flower-heads.

Baron Van Dedem. A variety somewhat in the style of Coquelicot, but it produces much Iarger trusses and its flowers are nearly twice as large. In color it is of a glistening scarlet-blood-red. 25 cts.; strong, 50c.

Beranger. Ground-color white, delicately suffused with rosy pink, with a distinct red eye; height medium. 15 cts.; strong, 25 cts.

Bridesmaid. Pure white, with large, crimson-carmine eye; very fine; tall. 15 cts.; strong, 25 cts.

Caran d'Ache. Bright geranium-red, with old-rose shadings and white eye; very effective; height medium. 15 cts.; strong, 25 cts.

Champs Elysees. Intense, rich purple-crimson; medium. 15 cts.; strong, 25 cts.

Coquelicot. A fine orange-scarlet, with crimson eye; very fine; medium. 15 cts.; strong, 25 cts.

Dr. Konigshofer. Brilliant orange-scarlet, with dark blood-red eye. Finer and more brilliant in color than Coquelicot, and more compact. 25 cts.; strong, 50 cts.

Eclaireur. Brilliant rosy magenta, with lighter large halo. An excellent sort; tall. 15 cts.; strong, 25 cts.

Elizabeth Campbell. Very large spikes, with flowers of quite a new color-light salmon changing to pink in the center. It is the best pink Phlox and the best of bedders. 25 cts.; strong, 50 cts.

Eugene Danzanvillier. Lilac, shading white. 15 cts.; strong, 25 cts.

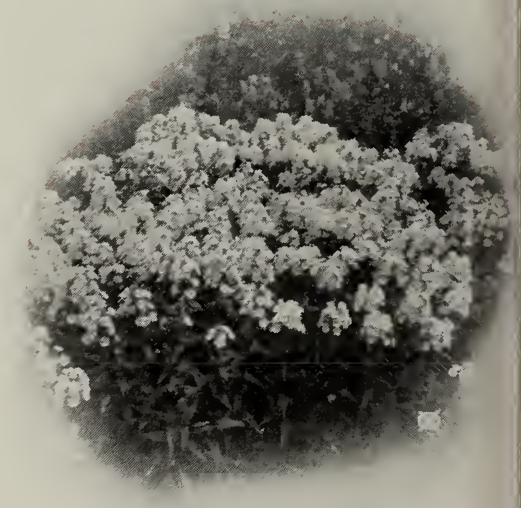

Elizabetls Campbell Pblox 


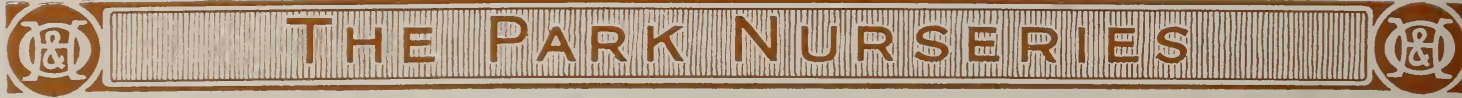

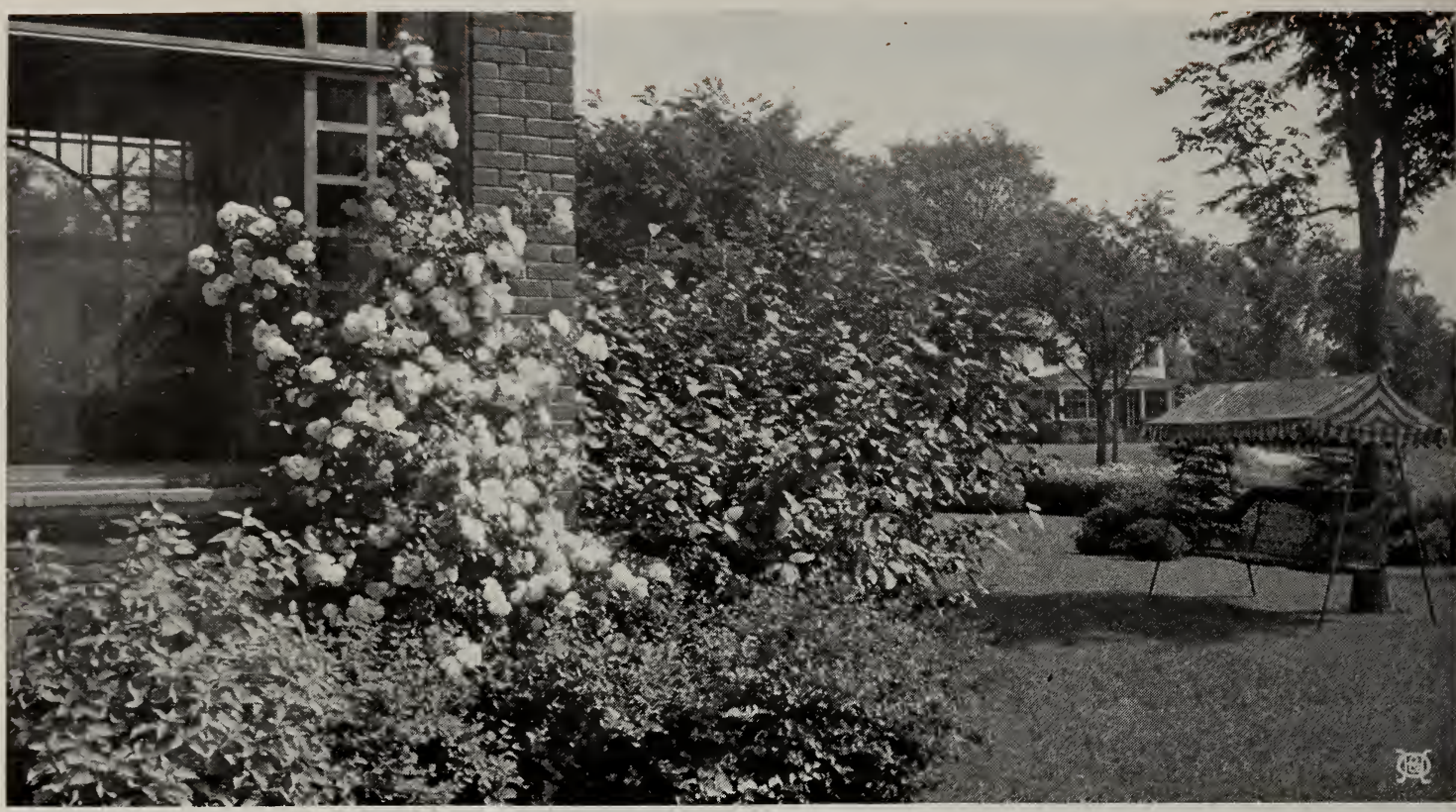

Climbing roses on a south exposure always do well

\section{HARDY ROSES}

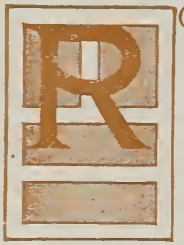

OSES-the name is an inspiration to garden-lovers-are justly classed among the showiest and best plants for decorating the home grounds. No garden is complete without them, no arrangements satisfactory that neglect them; in fact, they are indispensable. Fortunately, it is possible to select from the numerous species and garden forms varieties that are adapted to almost every requirement.

During the past few years, a larger number of new varieties of Roses have been introduced and sold which have no practical value in our climate. For this reason, we take great care to include in our lists only such varieties as are worthy of general cultivation, and are hardy. We have necessarily confined our descriptions to a few leading varieties.

When to Plant.-We recommend spring planting, as our winters are too severe for planting in the fall. Dormant plants should be set early. Our potted plants can be set as soon as danger of frost is past, and up to June 1.

Location.-Roses require a good warm location, where they will get sufficient sunshine.

Soil.-They will grow in any rich soil. A liberal supply of fertilizer, with good cultivation, will improve both flower and fragrance.

\section{PRICES OF ROSES}

Prices of all Roses, except where noted, are given in the table prices and are made for two-year, strong plants. We make prices for the dormant bushes, also for potted plants; those potted are the same size, but are started and can be planted with a ball of earth, thus assuring success under ordinary conditions. The dormant plants require a longer time to start.

2-year, strong dormant plants

2-year, strong potted plants

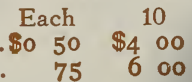

\section{HYBRID PERPETUAL ROSES}

Alfred Colomb. Cherry-red, passing to bright rich crimson; flowers

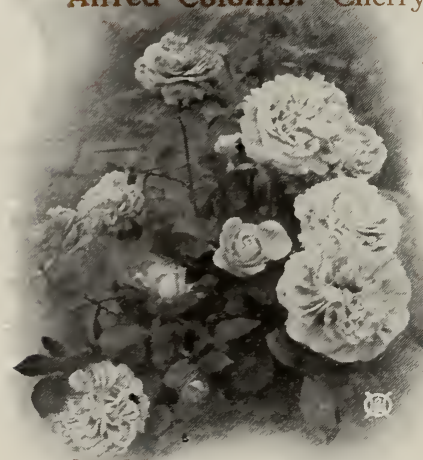

Paul Neyron (see page 65) extra large, double and full.

Anna de Diesbach. Brilliant crimson; a superb garden sort; fragrant.

Baron de Bonstetten. Rich dark red, passing to velvety maroon; highly fragrant.

Captain Christy. Very large and full flower, color shell-pink, shading darker in center; strong grower.

Captain Hayward. Crimson-carmine; Iarge perfect form; fragrant and very satisfactory. Clio. Flowers large, of fine globular form; flesh-color, shaded rosy pink center.

Eugene Furst. Dark crimson of a beautiful striking shade; strong grower.

Fisher Holmes. One of the choicest. Color brilliant carmine-crimson.

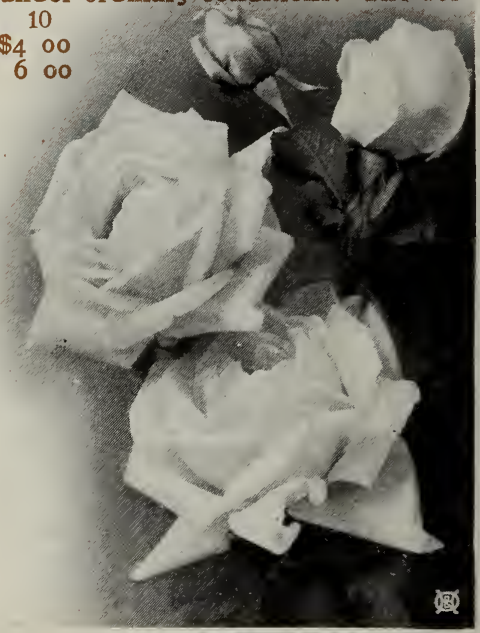

Frau Karl Druscbki (see page 65) 


\section{(通) SAINT PAUL,MINN. (8.}

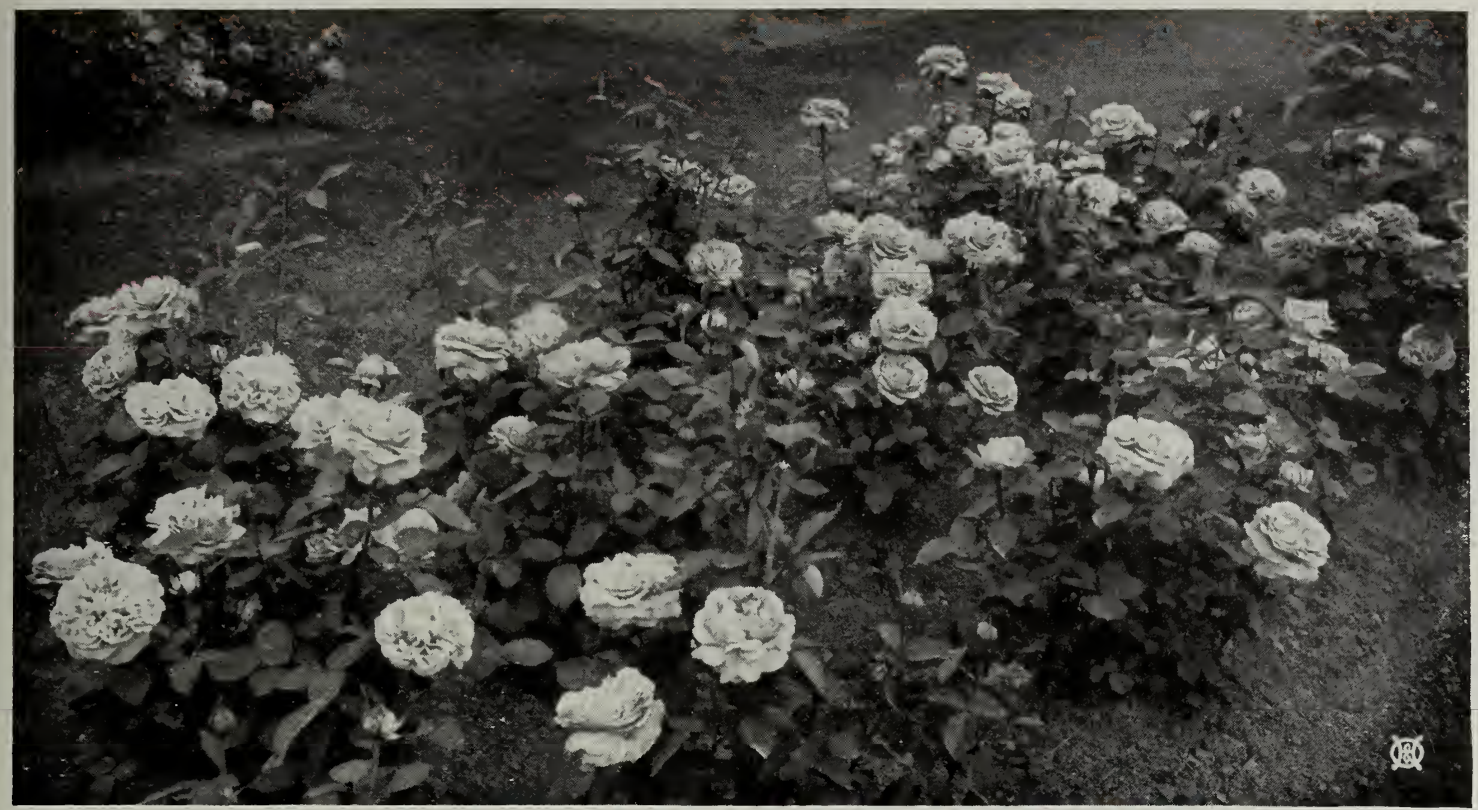

The joy of gardening can be fully realized with a bed of Roses like this

HYBRID PERPETUAL ROSES, continued

Frau Karl Druschki. Flowers are very large; beautiful, pure silvery white, with very deep bud. This is the best white Hybrid Perpetual yet introduced.

General Jacqueminot. Brilliant crimson; Iarge and very fine; one of the handsomest and most showy Roses of this color.

John Hopper. Bright rose, with carmine center; semi-globular; free bloomer.

Louis Van Houtte. Crimson-maroon; Iarge, full and fragrant.

Madame Gabrielle Luizet. A magnificent pink Rose; very large and possesses a pleasing fragrance.

Magna Charta. Bright pink, suffused with carmine; very large, full and fragrant.

Margaret Dickson. Pure white; fine form, very large; a strong grower and a free bloomer.

Marshall P. Wilder. Color cherry-carmine, richly

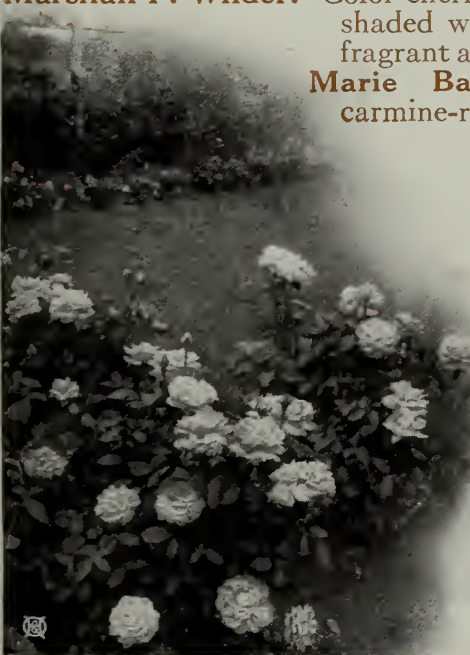

Madame Gabrielle Luizet

\section{YELLOW ROSES}

Price, 2-yr., strong, dormant plants, 50c. each, \$4 for 10

Harison's Yellow. Semi-double; bright yellow; showy and fine blooms very early; one of the best of its color.

Persian Yellow. Deep golden yellow; semi-double.

Soleil d'Or. This Rose is the result of a cross between Persian Yellow and Antoine Ducher. It is a fine, strong grower, producing superb, conicalshaped buds varying from gold and orange-yellow to reddish gold shaded with nasturtium-red.

\section{MOSS ROSES}

Blanche Moreau. Pure white; Iarge, full, perfectly formed.

Henry Martin. Rich, glossy pink, tinged with crimson; large, globular flowers, finely mossed.

Princess Adelaide. Fine reddish blush; large and igorous.

William Lobb. Violet-red; a strong grower.

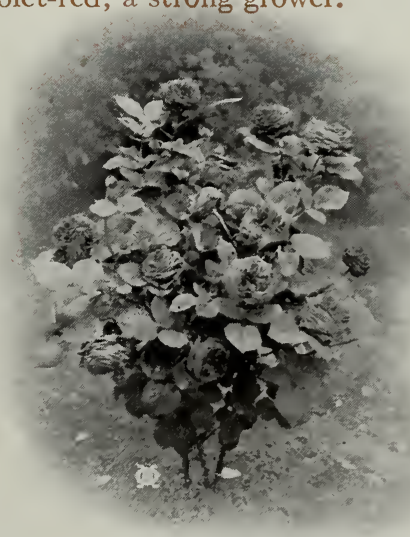

Prince Camille de Roban 


\section{(영) THE PARK NURSERIES (10id)}

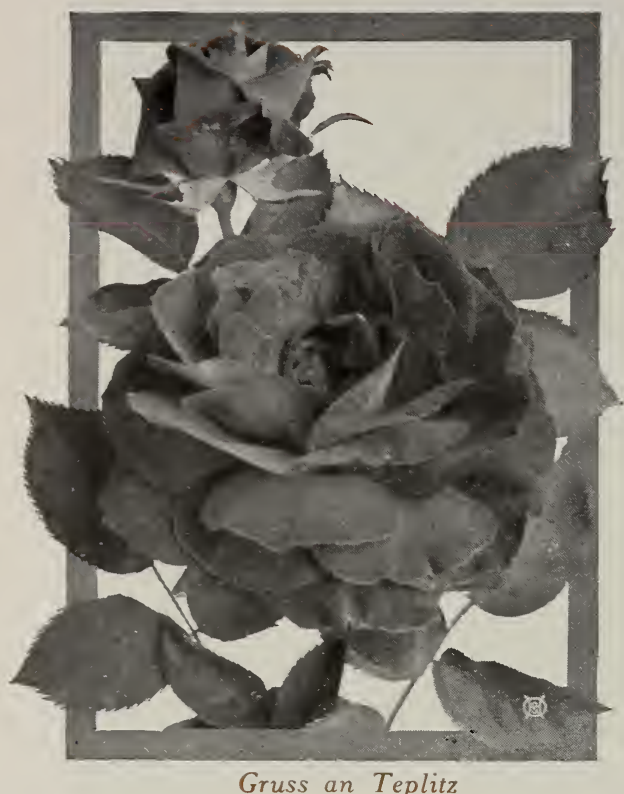

\section{TEA AND HYBRID TEA ROSES}

EVERBLOOMING ROSES

Our list of Hybrid Tea Roses comprises the very best to be had, many of the finest that have been introduced in recent years, and the leaders of the standard sorts.

Strong, 5-inch pot-plants, $75 \mathrm{c}$. ea. $\$ 6$ for 10 , except where noted

Augustus Hartmann. New brilliant geranium-red flushed orange; large, beautiful flowers. Mildew-proof. $\$ 1.50$ each, $\$ 12$ for 10.

Caroline Testout. Large, full, globular flowers of bright satiny rose, with brighter center.

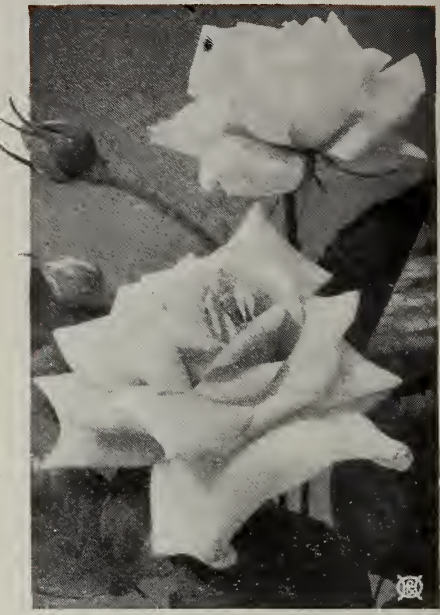

Kaiserin Augusta: Victoria

Cheerful. New; pure orange, the flame shading overspreading the petal, giving it a wonderful effect; its distinct orange-yellow base creating a color combination unknown to Roses. Sweetly scented. $\$ 2$ ea., $\$ 18$ for 10 .

Clothilde Soupert. Outer petals pearl-white, shading to a center of rosy pink.

Countess of Shaftesbury. Bright silvery carmine, deepening with age. \$1 each, \$8 for 10 .

Duchess of Wellington. Intense saffron-yellow stained deep crimson, changing to coppery saffron-yellow. G. C. Waud. Glowing orange-vermilion; one of the best standard Roses of its type.

Gorgeous. New; strong vigorous growth, dark olive-green. Flowers large and fuII; free bloomer. Color deep orange-yellow flushed copper-yellow. \$2 each, \$18 for 10.

Gruss an Teplitz. Scarlet, shading to velvety crimson; very fragrant; free bloomer.

Heinrich Munch. Soft pink; large and full; very satisfactory and very attractive in the garden.

Hermosa. Daintily cupped flowers of pretty pink.

Iona Herdman. A pure clear orange, the greatest color yet attained in clearness and brightness; true Hybrid Tea growth. The most beautiful yellow rose in cultivation. \$2 each, \$18 for 10 .

Juliet. Outside petals old gold, interior rich rosy red, changing to deep rose as flower expands.

Lady Mary Ward. Color rich orange, shaded deeper apricot, sweetly perfumed. \$1 each, \$8 for 10 .

La France. Silvery rose, changing to silvery pink; Iarge.

Kaiserin Augusta Victoria. Creamy white; sweetly fragrant; very full and Iarge flowers.

Killarney. Color flesh, shaded white, suffused pale pink.

Le Progres. Buds golden, changing to nankeen and pale yellow as the flower expands; large, cup-shaped.

Maman Cochet. Deep rose-pink, inner side of petals silvery rose; double; exquisite in bud or full blown.

Mme. Edouard Herriot. Coral-red, shaded yellow and scarlet. $\$ 1$ each, $\$ 8$ for 10 .

Mme. Jenny Guillemot. A very soft shade of nankeenyellow, suffused with carmine; very long buds.

Mrs. Andrew Carnegie. White; Iemon-tinted.

Mrs. Aaron Ward. Few Roses attract so much attention as this beautiful French introduction. Distinct Indian yellow, shading lighter toward edges. Free-flowering.

Mrs. Frank Bray. New. Deep rich coppery color, turning to coppery fawn and ivory-pink. \$1 each, $\$ 8$ for 10.

Mrs. Frederick W. Vanderbilt. New. Deep orange-red, shaded apricot-red. \$2 each, \$18 for 10 .

Mrs. George Norwood. New. Pink and gold. Almost a perfect pink Frau KarI Druschki, Lut more durable. $\$ 2$ each, $\$ 18$ for 10 .

Mrs. Hugh Dickson. New. Color deep cream with heavy suffusion of orange. Fragrant. \$2 each, $\$ 18$ for 10.

Mrs. Muir MacKean. New. Bright carmine-crimson, without shading. $\$ 1.50$ each, $\$ 12$ for 10 .

National Emblem. New. Beautiful dark crimson, shading to vermilion at the edge, with petals of ivory-like substance. Mildew-proof. \$2 each, \$18 for 10.

Rayon d'Or. Yellow cadmium toning to sunflower-yellow.

Richmond. Large; rich velvety crimson; fragrant.

Souvenir de Catherine Guillot. Coppery carmine, shaded with yellow.

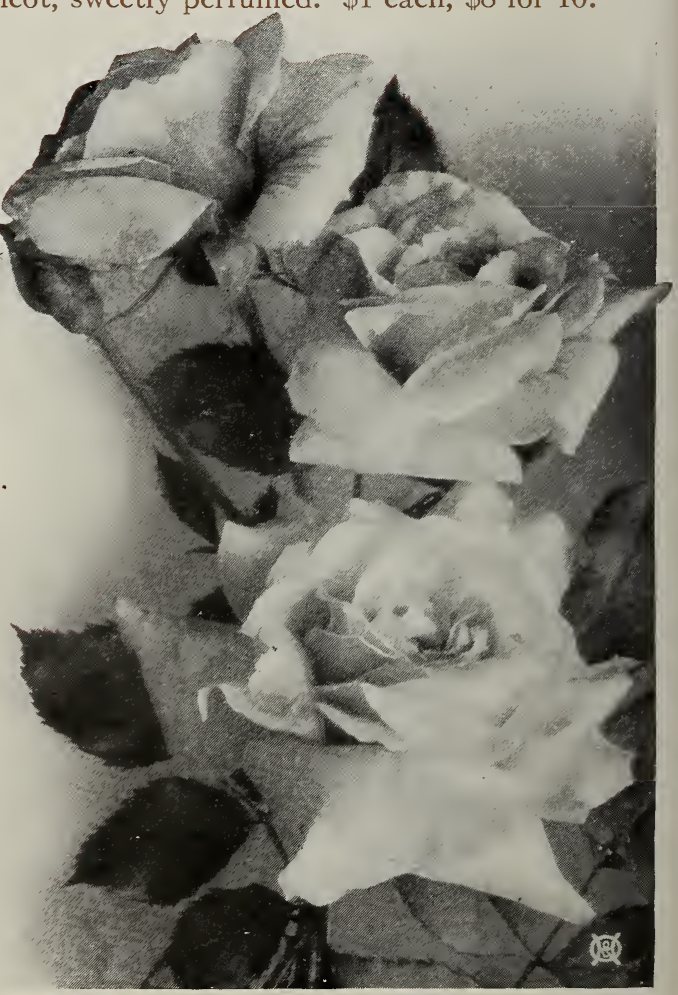

Mrs. Aaron Ward, the brilliant Hybrid Tea 


\section{BUSH ROSES}

This type of Roses is desirable in connection with shrubbery plantings and to be grouped by themselves. They are good for banks, borders, and patchwork. They do not need protection and are of the single type. Their foliage is beautiful and gives a naturalistic effect.

2-yr., strong, dormant plants, 35 cts. each, $\$ 3$ for 10

Blanda (Meadow Rose). Large pink flower followed by red fruit, same as Rugosa; habit erect; red bark in winter.

Carolina. The flowers are pink and come in flat clusters. The individual blooms are 2 inches in diameter and delicately formed; fruit red and showy.

Lucida. May to July. A fine native, with rosy pink flowers. Does well on poor soil and grows very rapidly. Has red stems and hips in winter.

Multiflora. Its single, pure white blossoms are produced in immense quantities.

Rubrifolia. Quite unique and conspicuous for its high-colored, reddish purple leaves, retained throughout the summer. Deep red flowers.

Setigera. The typical Prairie Rose, with brilliant pink flowers. All modern landscape planters are now giving recognition to its merits and usefulness.

\section{CLIMBING ROSES}

2-yr., strong dormant plants, 50 cts. each, $\$ 4$ for 10

American Pillar. A single-flowering variety of great beauty, which appeals to everyone. The flowers are of enormous size, 3 to 4 inches across, of a lovely shade of pink, with a clear white eye and cluster of yellow stamens. These flowers are borne in immense bunches, and a large plant in full bloom is a sight not easily forgotten.

Crimson Rambler. The famous crimson-clustered climber, so extremely effective when grown on pillars and trellises. Combined with the waxy pale green, red-veined foliage, the crimson mass of bloom makes an irresistible effect.

Dorothy Perkins. Clear shell-pink, with flowers borne in clusters; full and double, with crinkled petals.

Exce!sa. The flowers are very double, produced in large trusses of thirty to forty, and almost every eye on

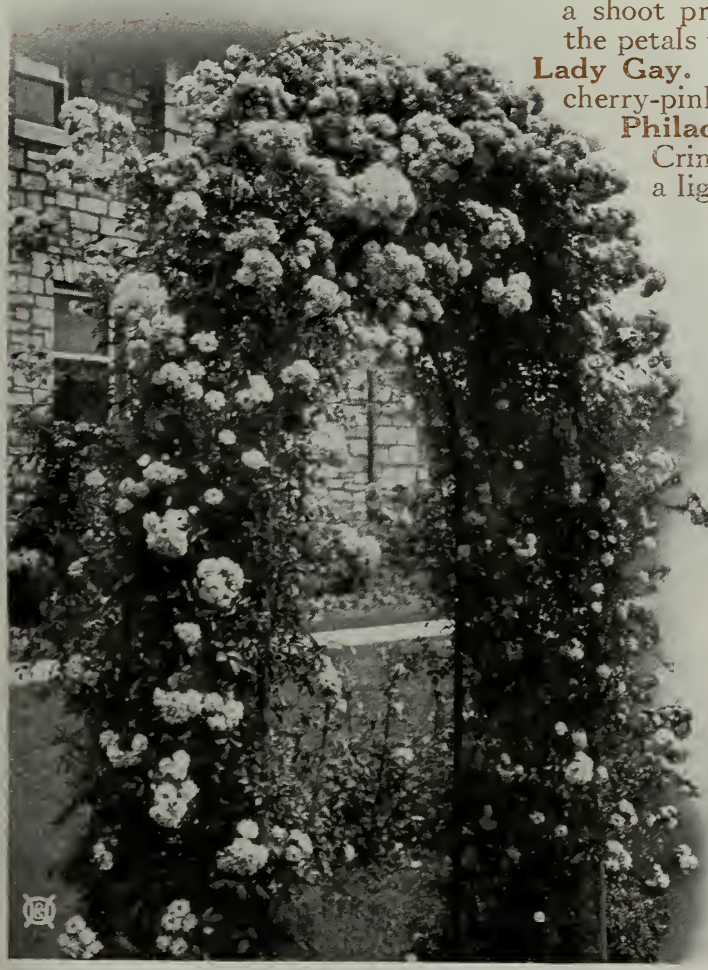

The most beautiful of all climbers, Dorotby Perkins

\section{tis}

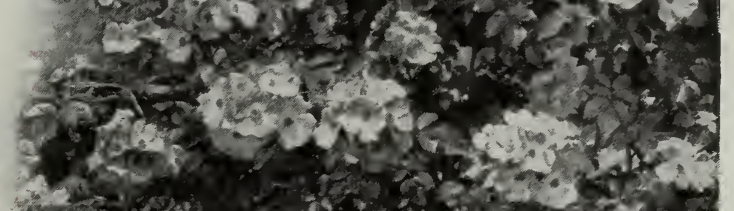
St:

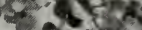
(x) -3r 510

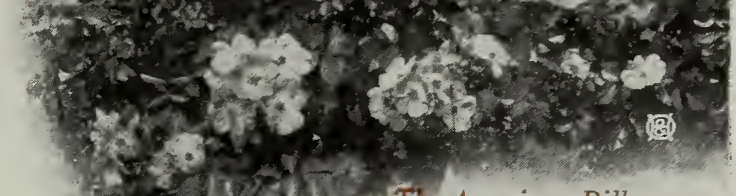
$4 x^{2} x^{2}$ if $x^{2}$ 1.

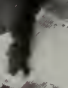

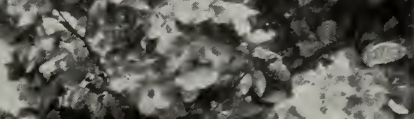




\section{(잉) THE PARK NURSERIES (180)}

DWARF POLYANTHA, or BABY RAMBLER ROSES

This type of Roses has been in existence only a few years. They were first used only as potted Roses, for the Easter trade, but were found excellent for outside planting, blooming constantly through the summer.

$2-y r$, strong, potted plants, $75 \mathrm{cts}$. each, $\$ 6$ for 10 , except where noted

Baby Rambler (Mme. Norbert Levavasseur). The original dwarf from the Crimson
Rambler. The wonderful persistency of its blooming makes it one of the choicest plants in cultivation.

Baby Tausendschon. Dwarf and bushy growth; flowers semi-double in pretty clusters; color flesh-pink.

Betsy Vannes. New. This grand novelty is a sport from Mrs. W. Cutbush, but a stronger grower with fine light green foliage. Flowers large, double, bright pure red, keeping this color until they wither. $\$ 1$ each, $\$ 8$ for 10 .

Erna Teschendorf. A vivid crimson Polyantha Rose.

The best red Baby Ramblers; holds its color in hot sume.

Elien Poulsen. New. A very free and vigorous type with large, full, and sweet-scented clusters of dark pink blooms.

Jessie. Richmond-red and does not fade; good house-plant or bedder.

Mrs. Wm. H. Cutbush. Pink Baby Rambler, of dwarf type and, when planted outside, blooms all summer. Flowers are pale pink, borne in extra large trusses.

Orleans. Geranium-red with a distinct center of pure white; free bloomer. A late introduction.

\section{WICHURAIANA, MEMORIAL or EVERGREEN ROSES 2-year, strong, dormant plants

Gardenia. Bright yellow flowers. Delightfully fragrant. One of the best.

Manda's Triumph. Flowers pure white, very double, produced in clusters of from ten to twelve.

South Orange Perfection. Similar to the preceding in growth.

Universal Favorite. Vigorous grower, with long, branching shoots that are covered with dense, bright green, shining foliage. Flowers are very double.

Wichuraiana. A low, trailing species, its stems creeping on the earth as closely as ivy, and forming a dense mat of very dark green, lustrous foliage. The flowers are produced in greatest profusion, and in clusters.

\section{SWEETBRIER ROSES}

The foliage is deliciously scented; the flowers are of the most beautiful tints and produced in great profusion; perfectly hardy.

2-year, strong dormant plants rose-colored flowers.

Anne of Geierstein. Large, handsome, deep crimson flowers; graceful branching habit; delightfully fragrant.

Lady Penzance. Beautiful soft tint of copper, base of petals bright yellow; very fragrant; free bloomer.

Rubiginosa. The well-known Sweetbrier, with highly scented

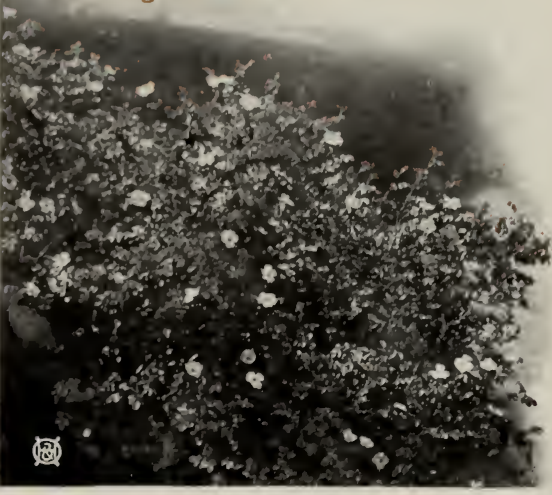

Sweetbrier type of Roses
Each

foliage, pink, fragrant flowers and quantities of bright hips. Blooms in June.

\section{TREE ROSES}

Our Tree Roses are grafted on hardy Rose-stalks, 4 to 5 feet high. We offer Hybrid Perpetuals, Hybrid Teas, Crimson Rambler and Baby Rambler. Fine, strong trees that will bloom nicely the first year. Each 10 mr., strong dor-
mant plants...\$I $50 \$ 1250$ 2-yr., strong potted plants.... 2 2 $00 \quad 18$ o0

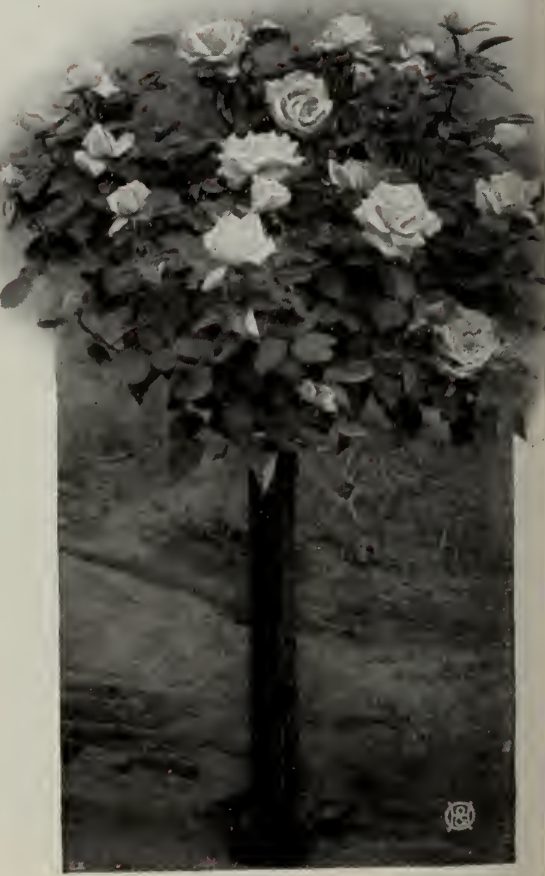

Type of our Tree Roses 


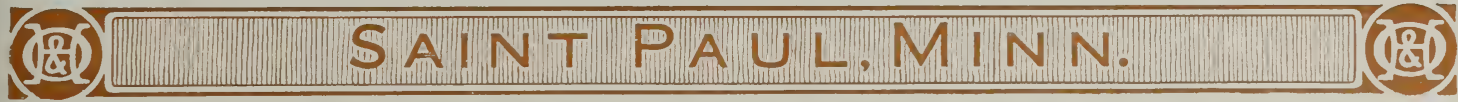
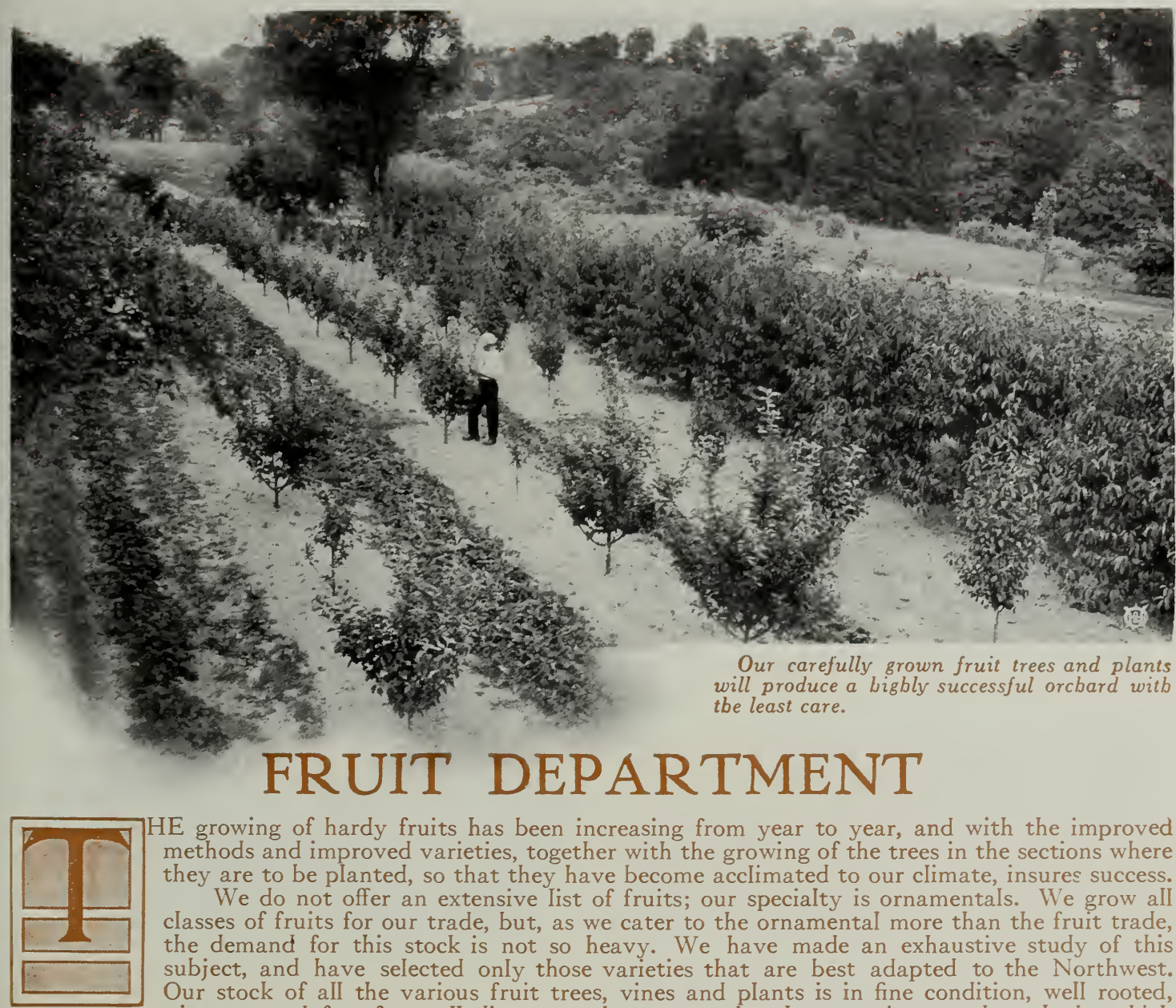

$\mathrm{HE}$ growing of hardy fruits has been increasing from year to year, and with the improved methods and improved varieties, together with the growing of the trees in the sections where they are to be planted, so that they have become acclimated to our climate, insures success.

We do not offer an extensive list of fruits; our specialty is ornamentals. We grow aI classes of fruits for our trade, but, as we cater to the ornamental more than the fruit trade, the demand for this stock is not so heavy. We have made an exhaustive study of this subject, and have selected only those varieties that are best adapted to the Northwest. Our stock of all the various fruit trees, vines and plants is in fine condition, well rooted, vigorous and free from all disease, and grown under the most improved methods, which has been the secret of our success in this business, furnishing our patrons what they want and of the very best quality, at reasonable prices.

\section{APPLES}

Apples require a well-drained soil, and the Iocation best suited is an east or northeast slope, with clay soil preferred to sand. Trees should be planted about 25 feet apart. Each $10 \quad 100$

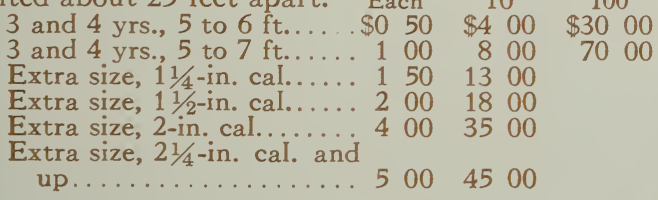

\section{APPLE NOVELTY}

We have a stock of top-worked Apple trees, grafted with three and four varieties, such as Duchess of Oldenburg, Wealthy, Okabena and Patten's Greening, making it possible to get three and four varieties from the same tree. Such trees are just the thing for city lots.

5 to $6 \mathrm{ft}$. . . .

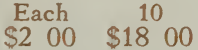

Specimens

250

2300

Anisin. A most valuable sort from Russia. Fruit of medium size, most excellent flavor, and keeps a long time in good condition.
Duchess of Oldenburg. Fruit extra size, pale green, shading to white, beautifully striped; tender and juicy; highly esteemed for market and domestic use. One of the most profitable. August and September.

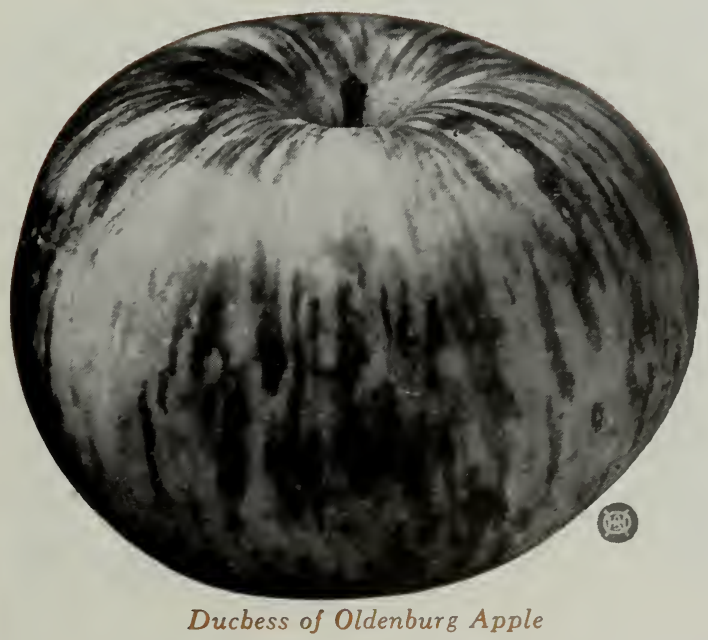




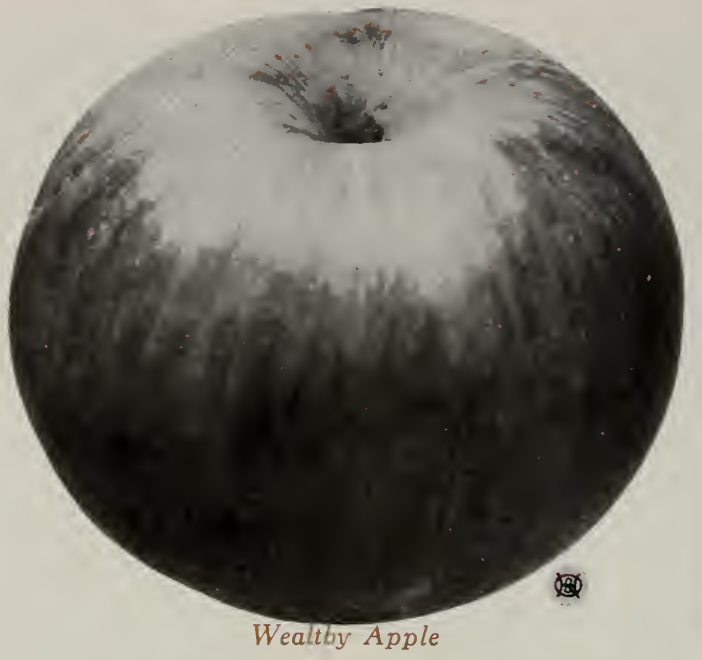

APPLES, continued

Hibernal. This variety represents what is probably the hardiest type of the Russian family, and is known as the standard of hardiness. Tree vigorous, spreading and productive. Fruits large to very large, irregular in shape, greenish yellow, with dull bronze-red on sunny side. November to December.

Longfield. A free, upright-grower; fruit medium to large, yellowish green with red stripes. December to March.

Malinda. An exceedingly hardy variety, one of the very best in the entire list for the Northwest. Medium to large; rich yellow, with duII blush; white dots; flesh yellowish, white, frrm, subacid, crisp and juicy. A splendid cooking Apple. December to March.

Northwestern Greening. Fruit a pale green, sometimes tinted with a little red. Very large, and of excellent quality. One of the finest for cooking. March to April.

Okabena. A seedling of Wealthy, fertilized by Duchess. The fruit is medium in size, slightly flattened, very highly colored where exposed to the rays of the sun, resembling Duchess. The flesh is fine-grained. As an eating Apple it cannot be excelled.

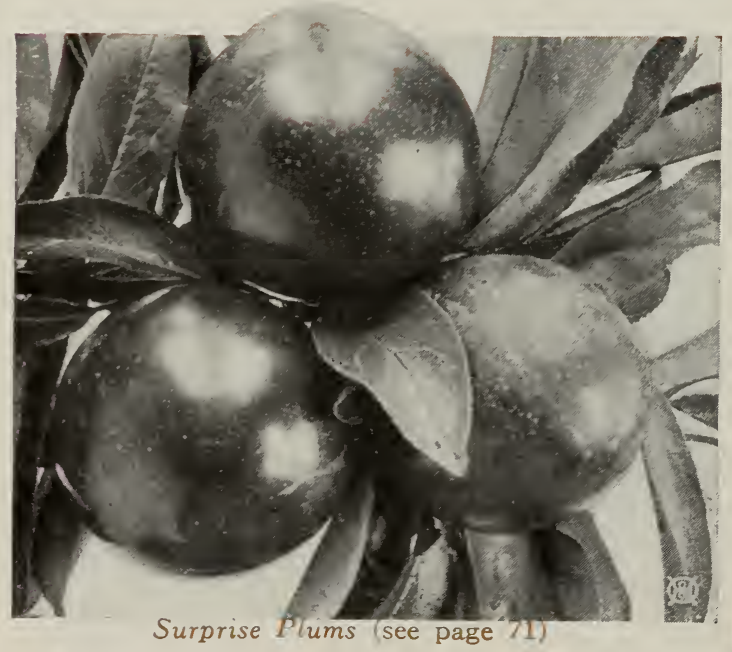

Patten's Greening. A seedling of Duchess and equal to it in hardiness and productiveness. Fruit large, uniform size, pleasant acid, equally good for cooking or eating. One of the best for the Northwest. February to March.

Peerless. Minnesota origin. Fruit medium to large; yellowish green with stripes. Tree vigorous, grows upright; has been extensively planted. October to December.

Wealthy. Minnesota origin. Tree very hardy, an early and abundant bearer; fruit dark crimson in color; flesh crisp and sub-acid; white, tinted with red; quality second to none. The best commercial Apple for Minnesota. November to February.

Wolf River. Wisconsin origin. One of the largest Apples grown in the North; color yellowish green with stripes of carmine, very handsome and showy; flesh nearly white. Tree vigorous and fairly productive for a Iarge Apple. October to January.

Yellow Transparent. Russian origin. One of the earliest of Apples; fruit medium; smooth, transparent skin, clear white, becoming pale yellow when fully ripe; flesh white and tender. Tree is moderately vigorous and a good annual bearer. July and August.

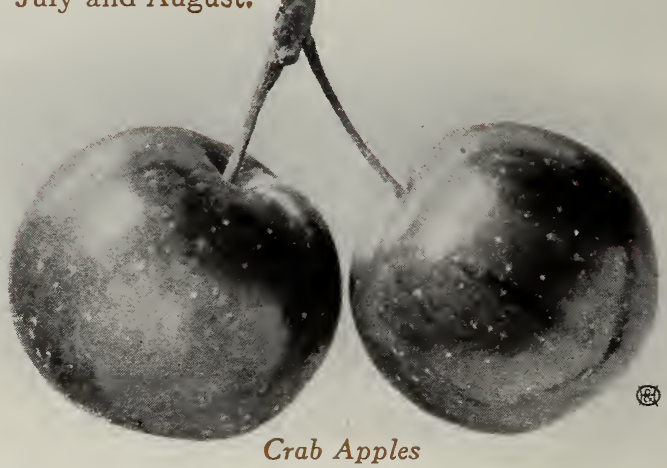

\section{CRAB APPLES}

Prices same as Standard Apples

Early Strawberry. Tree a good grower, symmetrical, hardy; fruit size of Transcendent, red striped, excellent for eating.

Hyslop. One of the most popular of the Crabs, a good grower and very hardy; fruit Iarge; deep crimson; flesh white tinted with red, an abundant bearer. September to November.

Minnesota. Hardy, medium grower; fruit large; color light with blush on sunny side; quality excellent. In size, beauty and keeping qualities it is the best. January to February.

Siberian. Fruit smaII, round; flavor sour and acid; excellent for jelly, but too small for other purposes. Tree is a good grower and handsome. October.

Whitney. One of the largest; glossy green, splashed with carmine; frrm, juicy, pleasant; great bearer; excellent for cider. August and September.

\section{PLUMS}

The class of Plums we offer are those that are perfectly hardy. Many of the best varieties known as Japan and European sorts will not stand our severe climate, hence we offer only those that can be grown in Minnesota, known as the American type. Much improvement has been accomplished in recent 


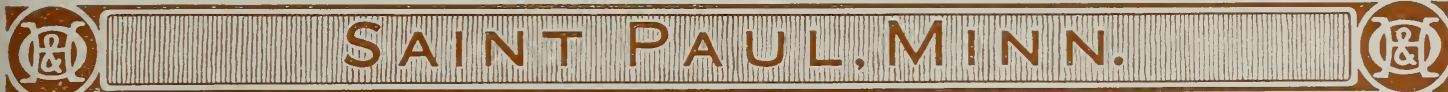

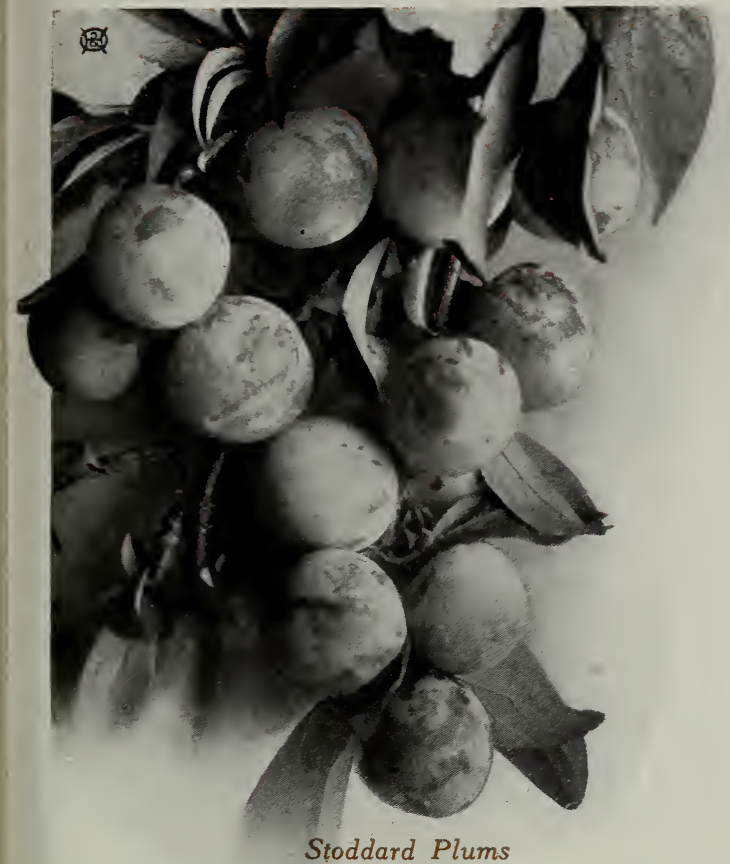

PLUMS, continued

years by seedlings or crossing. Plums should be set in clusters so they will pollenize, as their blossoms are male and female.

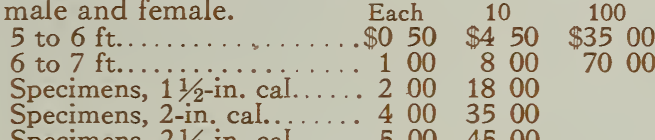

Prices of Cherries, except where noted

$$
\begin{aligned}
& 4 \text { to } 5 \mathrm{ft} \text {. } \\
& 5 \text { to } 6 \mathrm{ft} \text {. . } \\
& \begin{array}{ll}
\text { Each } & 10 \\
\$ 0 \quad 50 & \$ 4 \quad 50
\end{array} \\
& \text { Specimen trees............ \$2 to } 500
\end{aligned}
$$

Early Richmond. An exceedingly productive variety, fruit dark red of medium size; very early.

English Morello. Large, dark red, nearly black, tender, juicy and rich; tree dwarf and slender.

Montmorency. Large and finer than early Richmond, and one of the finest flavored Cherries grown. Tree strong, hardy and rapid grower, bears enormous crops.

Ostheimer. Large, nearly black when ripe; juicy and rich; fine for cooking and for market; late.

Vladimer. Of medium size; mildly acid; excellent. A Russian sort adapted for northern sections.

Wragg. Very similar to English Morellos, but said to be a hardier tree; originated in the West, and has proved entirely satisfactory.

Homer. A valuable seedling, originating in Minnesota, distinctly of the Morello type; fruit good size; flesh juicy, rich and of excellent quality; flavor similar to Early Richmond, color dark red. Has attracted much attention among Minnesota growers and is being planted quite extensively. 5 to 6 feet, $\$ 1$ each, $\$ 9$ for 10 .

\section{PLUM-CHERRY}

Compass. This hybrid, a cross between the Miner PIum and the Sand Cherry, has been a great acquisition to the fruit growers of the northern states. While the quality of the fruit is not so good as the Morello type, it is much hardier and can be grown in any section of the Northwest or western Canada. The tree is very productive, will produce good quantities of fruit at two years old, and continues to increase as the tree grows older; it has a tendency to over-produce. Fruit bright red, same size as the Morellos but with large pit. Prices same as Plums. yellow.

Forest Garden. Hardy; bears profusely; one of the earliest; size large, oblong; color mottled red and yellow; skin thin, juicy, sweet and rich.

Hawkeye. Very hardy and a strong grower. Fruit is not bothered with curculio. Large, mottled dark red; very attractive and of superior quality.

Surprise. This is considered the best of the native type of Plums. It is a seedling of Minnesota origin, and is by far the best and finest quality of any in cultivation, also the hardiest ever introduced. Fruit very large; skin medium thick, tender, bright red; flesh pale yellow; quality extra good. Trees are upright growers.

Stoddard. Fruit oblong, oval, Iarge, with little or no cavity, short and stout stem; color pinkish red over yellow; skin thick, making a good shipper, flesh yellow, fairly juicy and of good quality; tree a vigorous, upright grower and very hardy.

Wolf. One of the very largest and a perfect freestone. Excellent for cooking, or for serving with sugar and cream. Tree a good grower and very hardy.

\section{CHERRIES}

The Morellos are the only Cherries that are hardy in the Northwest, with the exception of some natives or crosses with the plum. The Morellos grow slow and are smaller trees and are commonly known as the Pie Cherry.

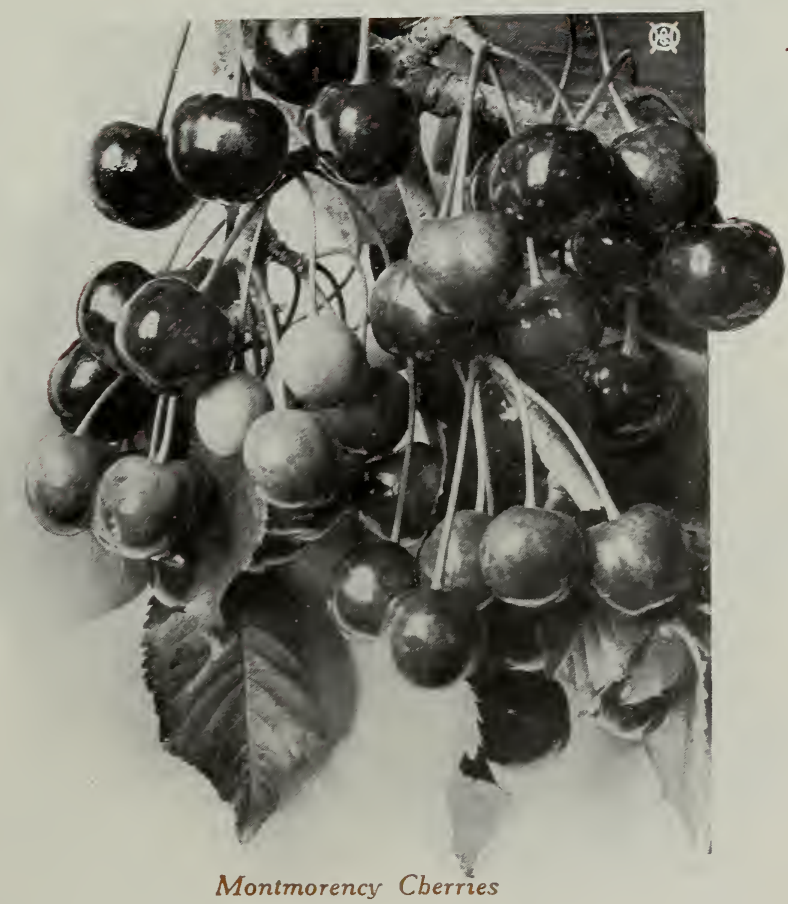




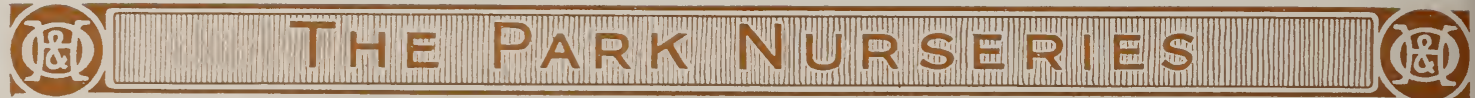

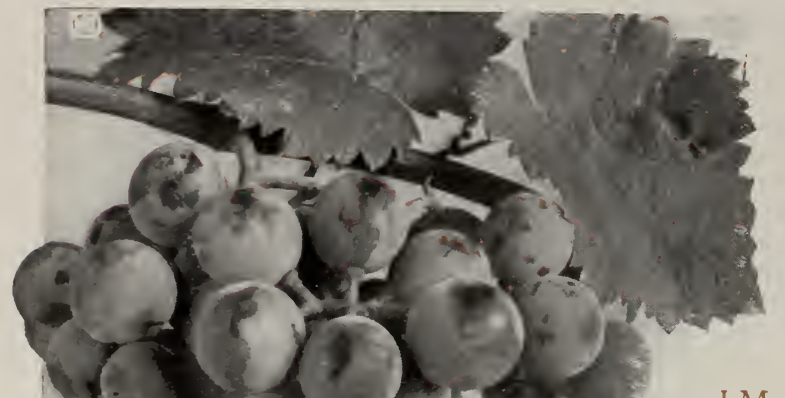

\section{GRAPES}

Along almost any garden fence or walk, there is room for vines to furnish fruit enough for the family, from July to November. For such locations they should be planted from 6 to 8 feet apart and kept cultivated. We list the best varieties for this climate.

\section{BLACK AND BLUE GRAPES}

Beta. Originated at the Minnesota State Experimental Station. Is a cross between the wild Grape and Moore's Early. The berry is Iarge, but quite acid, and not so good for eating as many of the others, but for pies, jelly, wine or grape-juice, it is fine. It is also a fine vine for trellis work, being perfectly hardy and requires no attention during the winter. Strong, 2 years, 50 cts. each, $\$ 4.50$ for 10 .

Concord. Large, handsome, black Grapes; a very hardy, reliable and productive variety, succeeding everywhere, and one of the most popular market sorts. More largely planted than any other black Grape. Strong, 2 years, 25 cts. each, $\$ 2$ for 10 .

Campbell's Early. A fine new Grape. Clusters Iarge, compact and handsome; berries large, nearly round; black, with light purple bloom; flesh firm, but tender; the seeds are few; quality rich, sweet, slightly vinous; a strong and vigorous grower with healthy foliage; it ripens very early; the berries do not drop easily from the clusters, and the fruit keeps a long time in perfection. Strong, 2 years, 50 cts. each, $\$ 4$ for 10 .

Moore's Early. Bunch and berry large, with a blue bloom; quality better than Concord; ripens ten days before Hartford. Strong, 2 years, 25 cts. each, $\$ 2$ for 10 .

Campbell's Early Grapes

Worden. Bunches Iarge, handsome; berries Iarge, sweet. Ten days earlier than Concord, and su-
perior to it in flavor; ripens well in cold localities. Contains very little pulp and is very juicy, making it a most valuable variety for growing for wine or grape-juice. Vine grows strong and vigorously, with large foliage. Strong, 2 years, 25 cts. each, \$2 for 10 .

\section{RED GRAPES}

Agawam (Rogers' No. 15). Dark red or maroon; bunches compact, very large; berries Iarge, oval; pulp soft; flavor sweet and aromatic. Ripens early; is very attractive. One of the best of the red varieties. Strong, 2 years, 25 cts. each, $\$ 2$ for 10 .

Brighton. One of the most desirable of the early red Grapes. Very large and handsome, Clusters under favorable conditions are more uniform than those of any other Grape. Strong, 2 years, $25 \mathrm{cts}$. each, $\$ 2$ for 10.

Delaware. Superior as a table Grape. Bunch medium, very compact; berries medium round; skin thin, of a beautiful dark red when fully ripe; flesh tender and juicy, exceedingly sweet. Strong, 2 years, 30 cts. each, $\$ 2.50$ for 10 .

\section{WHITE GRAPES}

Green Mountain (Winchell). Found growing in a garden on the side of the Green Mountains in Vermont, at an altitude of 1,400 feet, where it ripened its fruit perfectly Vine strong, vigorous, healthy, very hardy and productive. Bunch long, compact shoulder, green or greenish white. Always a favorite with those who prefer white Grapes. Strong, 2 years, 40 cts. each, \$3 for 10 .

Moore's Diamond. Vine is a vigorous grower, with large, dark, healthy foliage, very hardy. It is a prolific bearer, producing large, handsome, compact bunches. Strong, 2 years, 25 cts. each, $\$ 2$ for 10 .

Niagara. Vine hardy and strong grower; bunches very large and compact, many weighing fourteen ounces, sometimes more; berries large, skin thin but tough. The most popular white Grape. Strong, 2 years, 25 cts. each, \$2 for 10 .

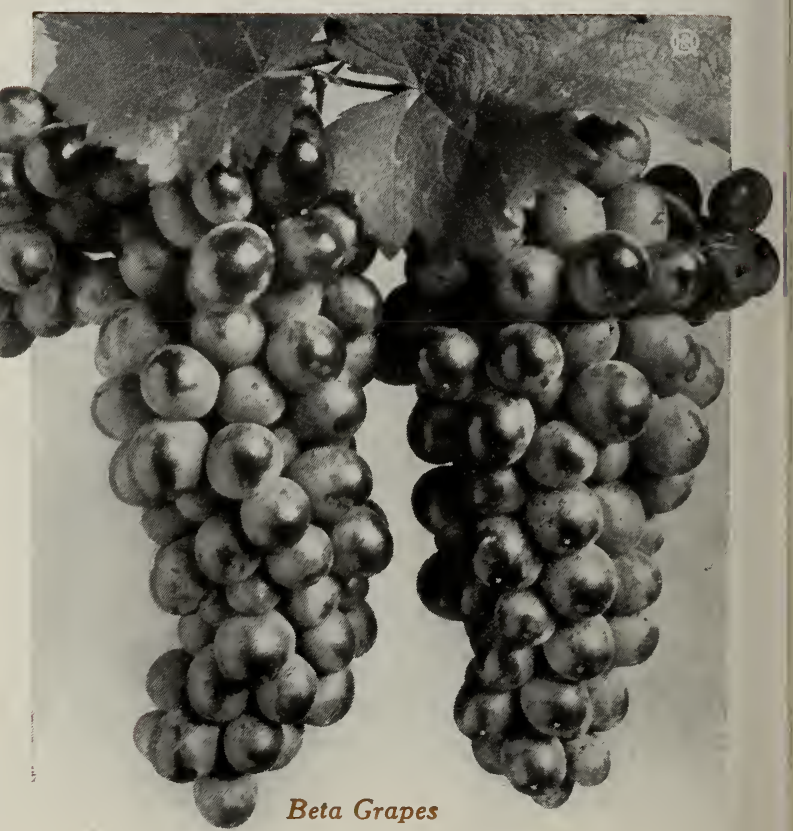




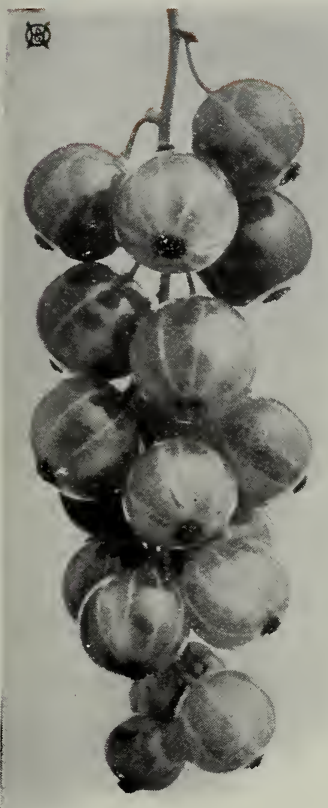

Perfection Currants

\section{CURRANTS}

A popular and profitable crop in a variety of soils. Its principal insect enemy, the currant worm, is easily kept in check by the liberal use of hellebore, applied immediately upon the first appearance of the worm. Plant 4 feet or more apart.

Prices, except where noted, strong, 2 years, $25 \mathrm{cts}$. each, $\$ 2$ for $10, \$ 6$ per I00; extra strong, $50 \mathrm{cts}$. each

Perfection, New. The color is a beautiful bright red; size as large as or Iarger than the Fay, the clusters averaging longer. A great bearer, resembling its parent, the White Grape, in this respect. The quality is rich, mild, subacid, plenty of pulp, with few seeds. After three years' trial, this fruit was the first to receive the $\$ 50$ Gold Medal of the Western New York Horticultural Society. Strong, 2 years, 40 cts. each, $\$ 3.50$ for 10 .

Black Naples. Very Iarge; black; bunches of medium Iength. Much valued for jellies. Strong grower and coarse leaves.

Cherry. Fruit of the largest size, deep red, rather acid; short bunches; growth strong, stout, erect; short-jointed shoots.

Fay's Prolific. This Currant has been widely planted and has given general satisfaction, and is one of the best red Currants known. Fruit very large, bright red and of excellent flavor; enormously productive.

Long-Bunch Holland. One of the best late varieties; bush very vigorous and hardy; clusters very long; berries medium to large, bright red and good quality.

Victoria. Large; bright red; Iong bunch; late in ripening and hangs long on the bush. One of the best; very valuable for its Iateness.

White Grape. Very large; yellowish white, sweet, or a very mild acid; excellent quality and valuable for the table. The finest of the white sorts.

\section{GOOSEBERRIES}

Gooseberries thrive well on a variety of soils, if weIl drained and fertile. The cultivation should be thorough early in the season.

European varieties are of large size and various colors. The green fruit is sent to the early markets and is profitable.

The best American Gooseberries are superior to European sorts in productiveness, hardiness, quality and freedom from mildew; the curse of European varieties and their seedlings is mildew.

Downing. (American.) "The standard of excellence." Large, pale green and covered with a white bloom; best in flavor and quality; a strong grower, productive and healthy; valuable for market. Strong, 2 years, 25 cts. each, $\$ 2$ for $10, \$ 12$ per 100 .

Houghton. (American.) Fruit medium size, red, thin-skinned, juicy, sweet and good in flavor and quality. Very productive. Strong, 2 years, 25 cts. each, $\$ 2$ for $10, \$ 10$ per 100 .

Industry. (European.) Bush a strong grower, and the most productive of European varieties; fruit large, dark red, mild, subacid, sweet and good flavor; one of the best for market, either green or ripe. Less subject to mildew than the others. Strong, 2 years, 40 cts. each, $\$ 3.50$ for 10 .

Josselyn. (American.) Good grower, fine foliage and a very profitable fruiter, when compared with any other Gooseberry in existence. The freest of aII Gooseberries from mildew, both in leaf and fruit. Strong, 2 years, 30 cts. each, $\$ 2.50$ for 10 , $\$ 15$ per 100 .

Keepsake. (European.) The blossoms of this variety are well protected by foliage, so that it is sure to set good crops in any ordinary year. The fruit is very large, pale yellow, of good flavor. Strong, 2 years, 40 cts. each, $\$ 3.50$ for 10 .

Pearl. (American.) The most prolific Gooseberry known. One bush produced 2,500 berries. It is free from mildew and is larger than the Downing. The skin is strong and makes the berry excellent for shipping. A splendid variety for preserving, and is strongly recommended for pies and sauces. The color is light green and quality first class. Strong, 2 years, 30 cts. each, $\$ 2.50$ for $10, \$ 15$ per 100 .

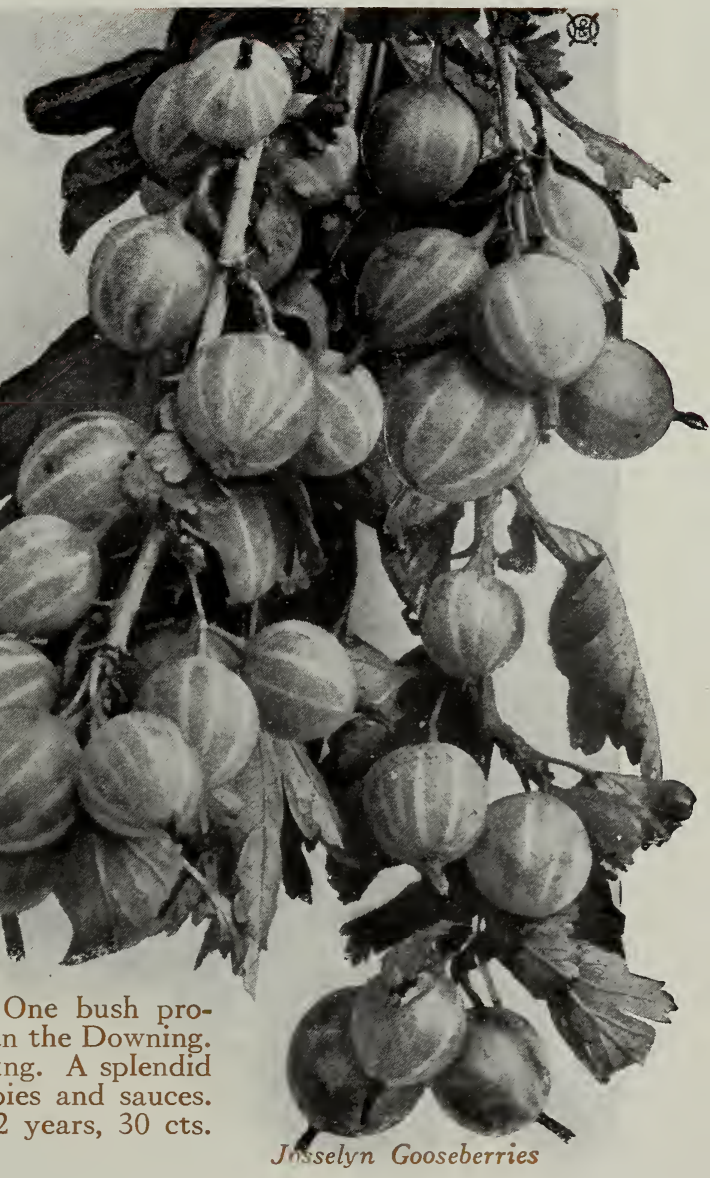




\section{RASPBERRIES}

For field culture, Raspberries should be planted in rows 4 to 6 feet apart, $21 / 2$ to 3 feet in rows, depending on the character of growth of sorts planted.

The first year after planting cut the canes about 2 inches from the ground, and when grown 18 inches pinch off the ends, which will cause them to branch; repeat this when a new growth comes, to make stocky plants. The following spring shear off a third of the wood, leaving a round bush.

Strong plants, I5 cts. each, \$I for Io, \$3 per Ioo, except as noted

\section{RED AND PURPLE RASPBERRIES}

Columbian. A new variety of great promise. It is a very vigorous grower and very hardy. Fruit purple and delicious for table or canning.

Cuthbert, or Queen of the Market. Fruit is large, luscious, and produced in the greatest profusion. Color deep rich crimson; fruit very frrm.

King. This is the best bright red variety under cultivation. It is also the hardiest and least affected by cold of the Raspberry family. Fruit of high quality. Fine for market and home use.

Loudon. A new red Raspberry which originated at Janesville, Wis. Large, broadly conical; beautiful red. Ripens about with Cuthbert, continuing later, and in quality better than that variety. One of the best.

St. Regis. Raspberries for four months! That's what you get when you plant St. Regis, the new everbearing variety. Moreover, they are not only Raspberries, but Raspberries of the very highest grade-in size, in brilliant crimson color, in firmness, in flavor. This has been aptly termed the "early-till-late" variety for it is the first red Raspberry to give ripe fruit, while it continues to produce berries without intermission until late in October. 15 cts. each, \$1.25 for $10, \$ 5$ per 100 .

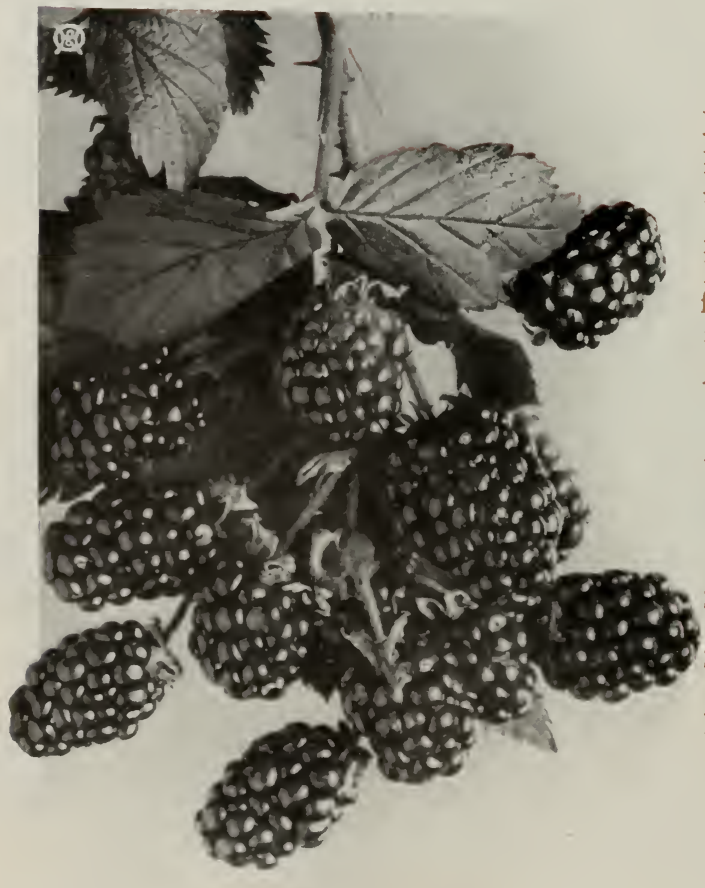

Eldorado Blackberries

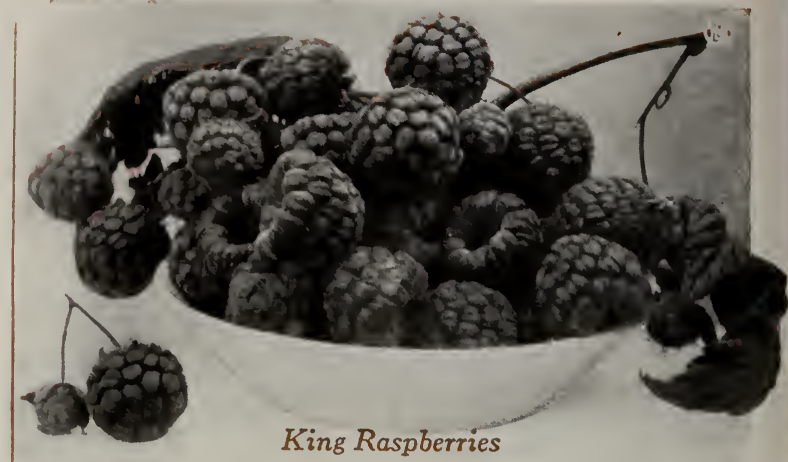

\section{YELLOW RASPBERRY}

Golden Queen. Large size, great beauty, high quality, perfectly hardy and very productive. Ripens in midseason. No home garden should be without it.

\section{BLACK RASPBERRIES}

Cumberland. The bush is hardy, a vigorous grower, and exceptionally productive. Fruit of uniform size, and larger than any known black Raspberry. Many specimens are from $7 / 8$ to $\frac{15}{16}$ of an inch in diameter. In quality it is equal to Gregg, ripening a few days earlier.

Gregg. A hardy blackcap; one of the best market Raspberries grown. Very productive, the yield under good cultivation is enormous. Berries very large; quality good, firm in shipping.

Kansas. Strong, vigorous grower, standing extremes of drought and cold, and bearing immense, early crops. Berries size of Gregg and of better color; jet-black, of best quality; presents a handsome appearance and commands highest price in market.

\section{BLACKBERRIES}

The ideal crop for obtaining money returns from poor Iands. Yet the cultivation of the vines should not be neglected, and liberal fertilizing should be accorded. Mulching is of great advantage, especially in poor soils. Plant in rows 6 feet apart, the plants 3 feet apart in the rows. Trim with a view to obtaining a crop of excellent berries from a few strong shoots to a plant rather than from many weak ones.

Strong plants, I5c. each, \$I for I0, $\$ 3$ per Ioo, except Lucretia Ancient Briton. This has proved one of the most profitable fruits for market growing. Plant hardy and very productive; fruit large and sweet.

Eldorado. New. This splendid variety is, perhaps, the best ever introduced. It stands when other varieties are winter-killed, and has never failed to produce enormous crops of its large, jet-black fruit, sweet and melting.

Snyder. One of the hardiest and best-known sorts grown in the West. Fruit large and of good quality. Early.

Stone's Hardy. Ripens a little later than Snyder and is very hardy.

Lucretia Dewberry. In size and quality this low-growing or trailing Blackberry equals any of the upright sorts. Its berries ripen before raspberries are gone, are large, soft, sweet and Iuscious throughout, with no hard corc. May be grown over walls, trellises or rocky slopes, where there is no room for other berries. Strong plants, 15 cts. each, $\$ 1$ for $10, \$ 4$ per 100 . 


\section{(透) SAINT PAUL,MINN. (道)}

\section{STRAWBERRIES}

The Strawberry will grow in any good garden soil where the ground has been thoroughly prepared. For family use plant 1 foot apart in the row, the rows 4 feet apart, allowing only enough runners to grow so as to form a bed 3 feet wide. Cover the plants lightly in winter with leaves or litter, which should be removed early in the spring.

Those marked $P$ have imperfect flowers and must be planted near the perfect-flowered kinds to insure fertilization.

\section{EVERBEARING STRAWBERRIES} $\$ 1.50$ per doz., \$6 per Ioo

Americus. One of the best of the midsummer an faII bearers. AII through August, September and October the vines are filled with ripe berries.

Forward. Fruit large, firm; dark red; round in form and never misshaped; best quality. Fruits from June to November. The best we have found, and the best in cultivation. \$2 per doz. $\$ 10$ per 100 .

Progressive. This variety has been tried for a number of years, and found to be one of the most productive. Fruits heavily in August and September, bearing an abundance of Strawberries out of the regular season.
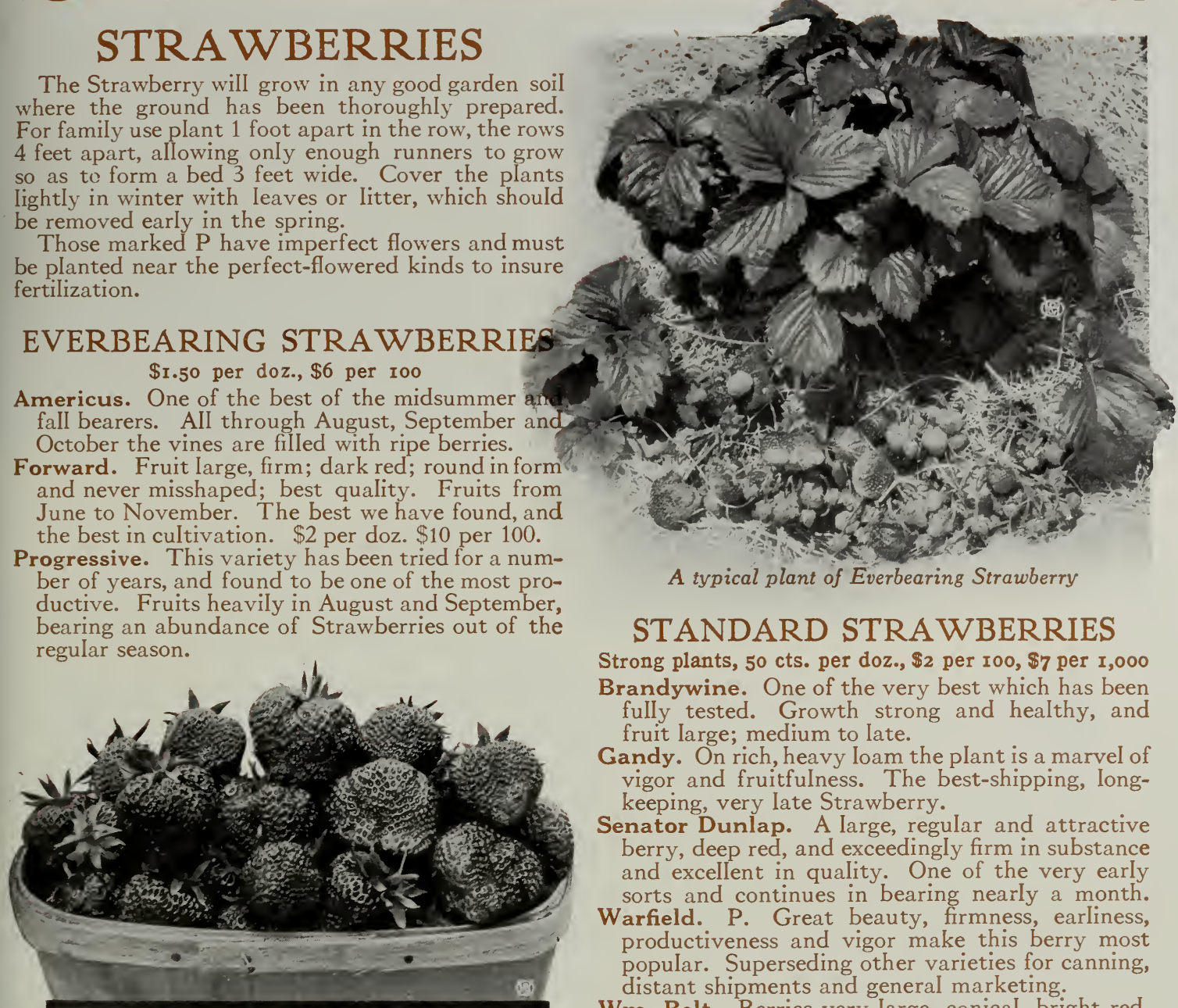

A typical plant of Everbearing Strawberry

\section{STANDARD STRA WBERRIES}

Strong plants, 50 cts. per doz., \$2 per I00, \$7 per I,000

Brandywine. One of the very best which has been fully tested. Growth strong and healthy, and fruit large; medium to late.

Gandy. On rich, heavy loam the plant is a marvel of vigor and fruitfulness. The best-shipping, longkeeping, very late Strawberry.

Senator Dunlap. A large, regular and attractive berry, deep red, and exceedingly firm in substance and excellent in quality. One of the very early sorts and continues in bearing nearly a month.

Warfield. P. Great beauty, firmness, earliness, productiveness and vigor make this berry most popular. Superseding other varieties for canning, distant shipments and general marketing.

Wm. Belt. Berries very large, conical, bright red, of good flavor. Very fruitful. Medium to late.

\section{VEGETABLE ROOTS}

Borders and beds of these plants are common in many gardens; they are usually weedy and neglected. A better way to grow both family and market crops is to set the roots 15 to 18 inches apart in rows. Spread the roots of Asparagus out well, firm the soil about them and leave the crowns about 2 inches below the surface of the soil.

\section{ASPARAGUS}

Strong, 2-year roots, 50 cts. per doz., \$1.50 per Ioo

Columbian Mammoth White. Produces numbers of great, thick, white shoots. Most attractive and profitable for canning.

Conover's Colossal. Really colossal, deep green shoots, from 1 to 2 inches in diameter, are sent up thickly from the crowns.

Palmetto. In great markets this Asparagus sells at top prices, on account of the great size and beautifuI appearance of its stalks.

\section{RHUBARB, or PIE-PLANT}

Strong roots, $25 \mathrm{cts}$. each, $\$ 2$ for $10, \$ 15$ per Ioo

Linnæus. Leaf-stalks large, tender, juicy; produced quite early.

Queen. The extra-large, tender stalks are a decided pink color, and delicious for canning or cooking. A very strong-growing sort.

\section{HORSE-RADISH}

Those having compared the freshly dug to that already prepared can appreciate its value. 50 cts. per doz., \$4 per 100.

\section{MINT}

The well-known garden Mint for sauces and seasoning. $\$ 1$ per doz.

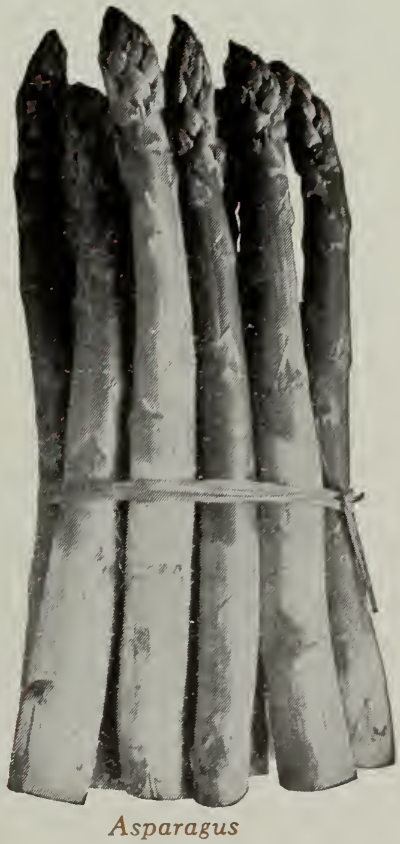




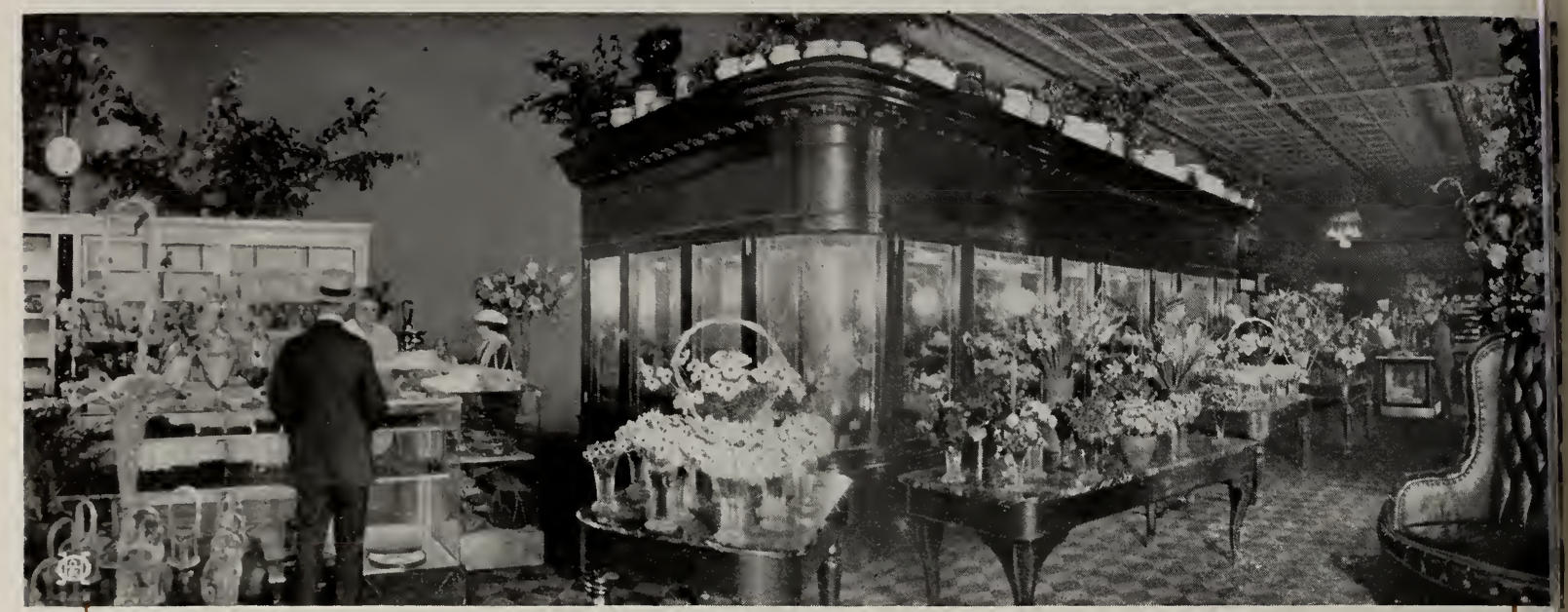

Our retail store, "The Home of Flowers," is one of the largest establishments in the United States

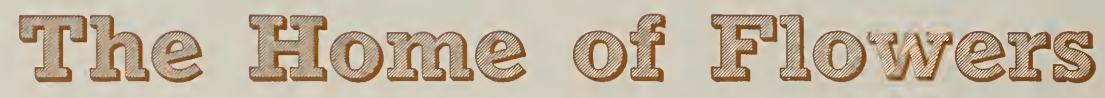

\section{(O)}

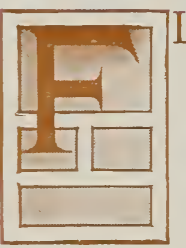

LOWERS are the Most Beautiful Gift of Nature, and appeal alike to people of wealth and culture as well as to those who are not so favorably situated. Everybody loves flowers. The proper arrangement of flowers is a study in itself, quite distinct from the growing of them. Many a good florist can grow flowers to perfection, but is unable to arrange them to give the best effect. It is our constant aim and study to properly arrange flowers so that they will be shown to the best possible advantage. By long experience, and studying color combinations and arrangements, it has become an art with us, and we are always pleased to give our customers the benefit of our experience. A diamond set in a lead ring would still be a diamond, but its chief charm would be lost by its unsuitable surroundings. So with flowers-the chief charm can be completely lost by inharmonious arrangements.

Our Store is the Iargest cut-flower store in America, and the best equipped west of New York City. Its dimensions are 50 by 150 feet, with a basement of the same size. In connection with the store we have a conservatory 50 by 60 feet, for displaying decorative and flowering plants, and an office 30 by 30 feet. Our store is open during the week from 7 a.m. to 8 p.m.; on Sundays and holidays from 8 a.m. to I p m. We can be reached by telephone or telegraph night or day, and can ship promptly on any train wanted.

Every Variety of Cut-Flowers known to the trade is handled by us in season, and a force of twenty-five clerks is kept busy attending to customers and filling orders. In the shipping department, only the best and most approved methods are employed. Old stock is never shipped out; only fresh-cut blooms are used for shipping purposes. Ail express shipments are taken direct by our messengers to the depot, the train time on all labels being plainly marked. By Iong experience we have Iearned just how to pack flowers so they will reach their destination in the best possible condition, no matter whether it be in the coldest days of winter or the hottest days of summer. We ship to all parts of the country adjacent to St. Paul, our territory including western and northern Wisconsin, northern Michigan, Minnesota, North Dakota, eastern Montana, South Dakota, and northern Iowa, while quite frequently we ship to more distant points in IIIinois, Michigan, Missouri and Nebraska, as well as to Manitoba, Alberta and Saskatchewan.

We Do Not Recommend Sending Flowers by Parcel Post, as the mails are too uncertain. Where customers wish flowers shipped by parcel post, we will pack them in the best possible manner and deliver to the post office in good condition, but will not be responsible for their arrival at destination. We always recommend shipping by express, and will send in that manner unless otherwise requested. 


\section{(1906) HOLM \&OLSON. INC. (180)}

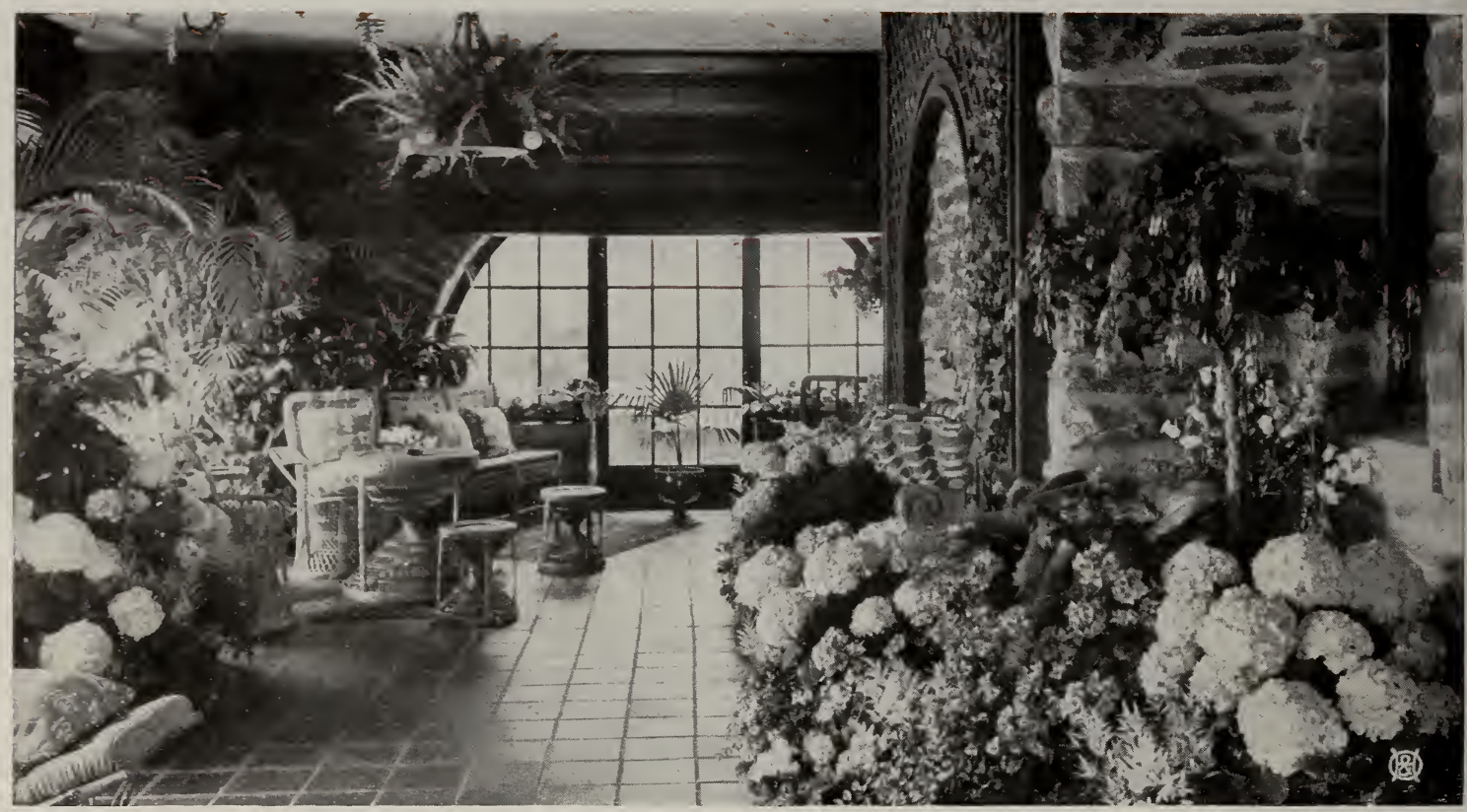

Interior of sun parlor showing decorative plants and appropriate furniture

\section{DECORATIVE PLANTS}

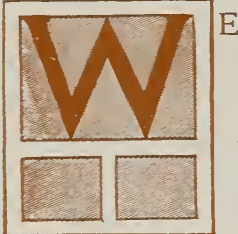

E DESIRE to state the fact that, while we are nurserymen and Iandscape architects, we are also florists, having the largest ranges of glass in the Northwest, and the largest and most attractive retail flower-store in America-known everywhere as "The Home of Flowers."

Large quantities of decorative plants are grown and imported by us. We supply them in all sizes, from the smallest to the largest. With plants we can furnish all necessary decorations in vases, boxes, pedestals, jardinières, fancy and ornamental baskets-in fact, everything for the decoration of sun-parlors, piazzas, lawns and interiors of homes or buildings. Our Palms, Ferns, Araucarias, Rubber Plants, etc., are unsurpassed in the Twin Cities. We shall be pleased to have you inspect our stock. We do not offer plants to send by mail. Our stock is large and select, giving immediate results, and we pack carefully and ship by express.

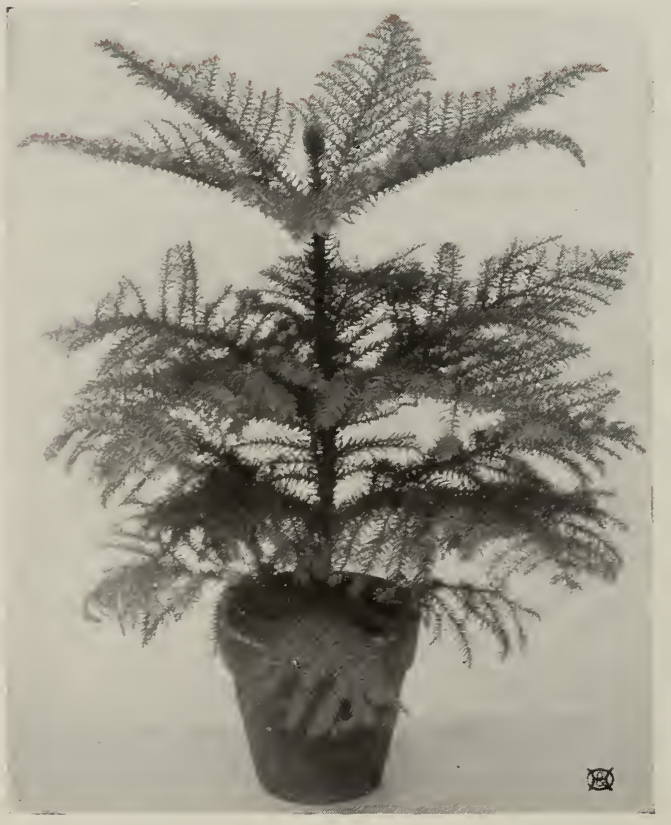

Araucaria excelsa
Ananas sativus variegatus (Variegated Pineapple). This is one of the most beautiful variegated-foliage plants in cultivation, not only for the greenhouse or conservatory, but also as a plant for room decoration. The leaves are from 1 to 2 feet long, with a central band of bright green, broadly margined with rich creamy yellow. 4 -inch pots, $\$ 1.50$ each; 6-inch pots, $\$ 4$ each.

Aralia elegantissima. Handsome plants for the warm conservatory and for exhibition purposes. Finely divided, metallic green foliage. $\$ 2$ each.

Araucaria excelsa (Norfolk Island Pine). The most beautiful of all tender evergreens, admirably adapted to house culture, as it is not affected by gas or dust; one of the finest for table decorations. Its deep green, feathery foliage is arranged in whorls rising one above the other at regular distances. $\$ 1$ to $\$ 3$.

Asparagus plumosus nanus (Lace Fern). Graceful climbing Asparagus, with beautiful, bright green, feathery foliage. 25 cts. to $\$ 1$.

A. Sprengeri. Has coarser foliage than Plumosus, and grows in long, exceedingly graceful sprays of rich green. Invaluable as a decorative plant, for hangingbaskets, pots or window-boxes. 25 cts. to $\$ 1$.

Aspidistra variegata: Foliage striped with white. A charming variegated plant; no two leaves alike. Will stand all sorts of neglect and abuse and grow rapidly. $\$ 1.50$ to $\$ 3$. 


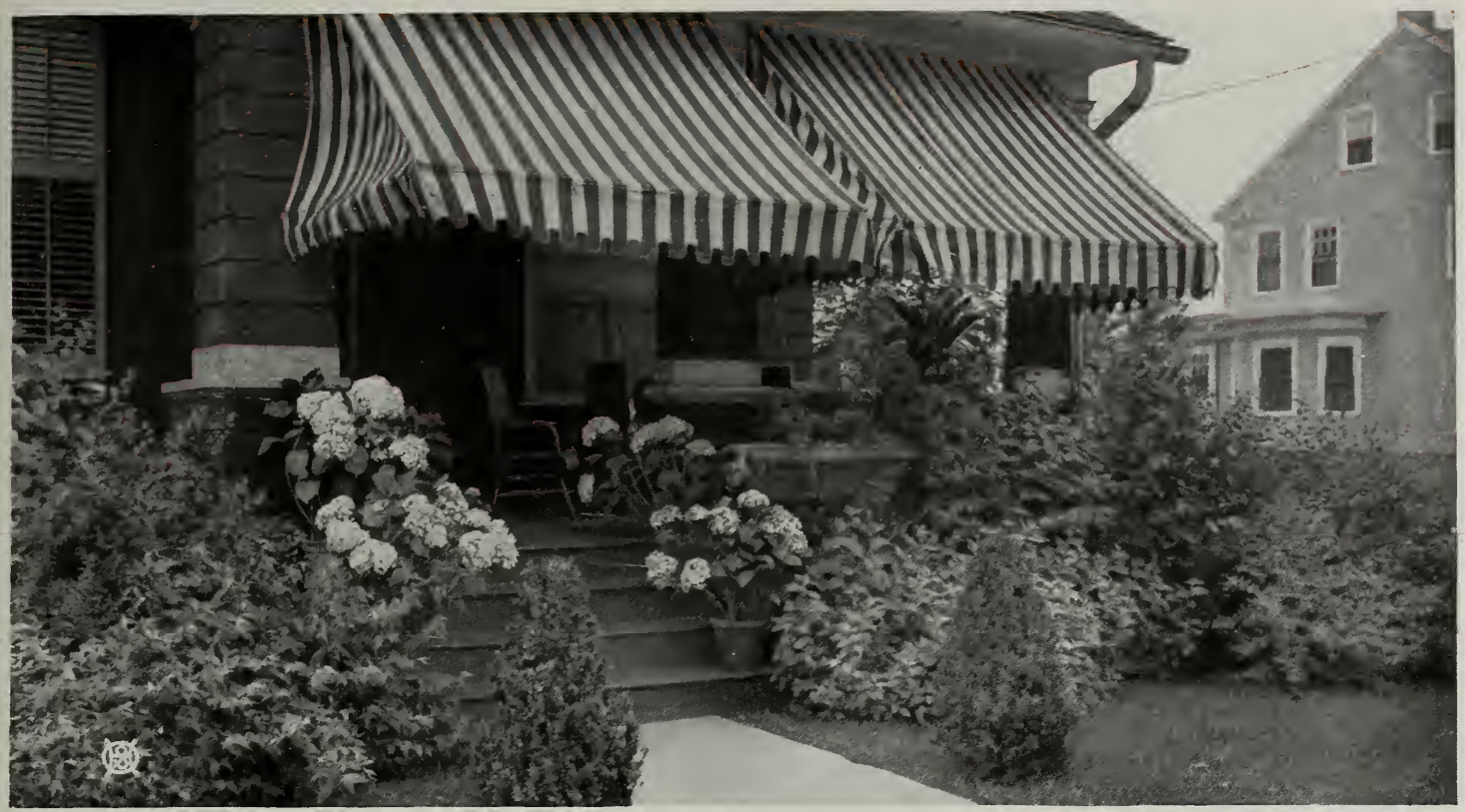

Hydrangeas in tubs give a wonderful touch of beauty to the bome (see page 80 )

\section{DECORATIVE PLANTS, continued}

CROTONS. For beauty of form and richness of coloring these charming plants cannot be excelled. They are equally as well adapted for outside bedding as for interior decorations. We can supply the leading varieties. $\$ 1$ to $\$ 5$.

C., Lord Wolseley. Long, narrow, recurving foliage, which colors to a very bright rosy crimson. $\$ 1$ to $\$ 1.50$.
DRACAENA indivisa. Long, graceful foliage; extensively used in vases. Stands full sun exposure and grows very vigorously, its long, slender foliage setting off other plants. 75 cts. to $\$ 2$.

D. terminalis. Brilliant crimson foliage, suffused and marked with pink and white. One of the most beautiful pot-plants for home adornment. Grows rapidly. $\$ 1$ to $\$ 1.50$.

\section{HANDSOME HOUSE FERNS}

Adiantum Croweanum. The hardiest Maidenhair Fern for home culture. Its peculiar, broad leaves and thin, wiry stems create an effect not possible with other sorts of ferns. 25 cts. to $\$ 3$ each.

A., Gloriosa (Glory Fern). An easy-growing form of that most beautiful of all Maidenhairs, Adiantum Farleyense, which, on account of its special requirements in atmospheric and temperature conditions, has been limited in its cultivation to specialists. This new variety, which is identical in every particular, has a stronger constitution and may be successfully grown under the same conditions, and makes a most delightfuI house plant. 50 cts. to $\$ 3$.

Asplenium Nidus-Avis (Bird's Nest Fern). Fine, glossy, undivided fronds, which grow in a whorl, and form a nest-shaped center, which gives it its popular name. $\$ 1$ to $\$ 5$.

Cibotium Schiedei. A very valuable Fern, with graceful, drooping light green fronds. One of the most desirable of the valuable Tree Ferns in cultivation. $\$ 2.50$ to $\$ 10$.

Cyrtomium falcatum (Holly Fern). Broad, dark, glossy green foliage; very ornamental, and quite different from other house plants. 15 cts. to $\$ 2$.

Nephrolepis Bostoniensis (Boston Fern). This variety has proved immensely popular as a house plant, on account of its graceful, robust habit and splendid durability. 50 cts. to $\$ 5$.

N., Roosevelt. A new type of the Boston Fern, but grows more compact and is a great favorite. Its fresh, green fronds are very graceful. $\$ 1$ to $\$ 3$ each.

N. Whitmanii. This is commonly known as the Ostrich-Plume Fern, with finely divided, feathery fronds. $\$ 1$ to $\$ 2.50$.

Miniature Ferns. In aII the choicest varieties for Fern-dishes. 21/2-in. pots, $\$ 1.50$ to $\$ 2.50$ per doz.

Our collection of Ferns is one of the largest in this country, and we can furnish nearly any variety in various sizes.

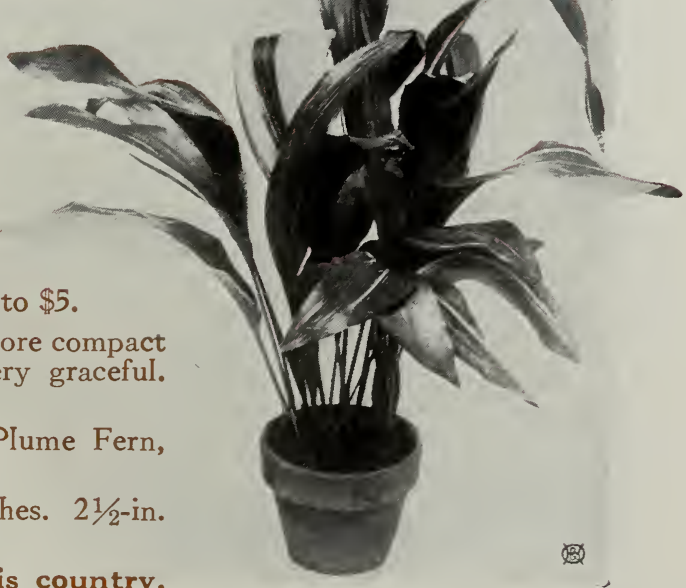




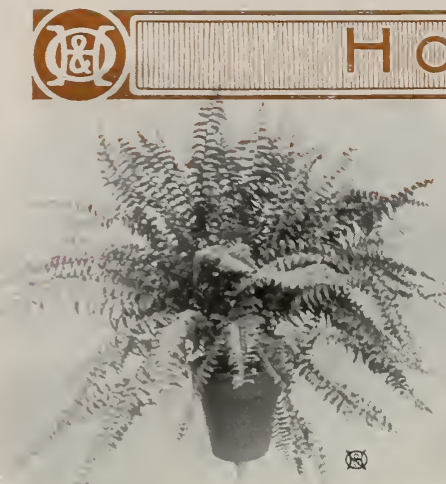

Roosevelt Fern (see page 79)
FICUS • Rubber Plant

Elastica. The well-known IndiaRubber Plant; nothing better for room decorations. Its dark green, shiny foliage is always handsome, and it withstands excessive heat and dryness without injury. $75 \mathrm{c}$. to $\$ 2.50$.

Pandurata. The most distinct Rubber Plant ever introduced. Its gigantic, broad, leathery, rich dark green leaves make it a fascinating house plant, and it is not affected by gas. Fine specimens, $\$ 3$ to $\$ 5$.

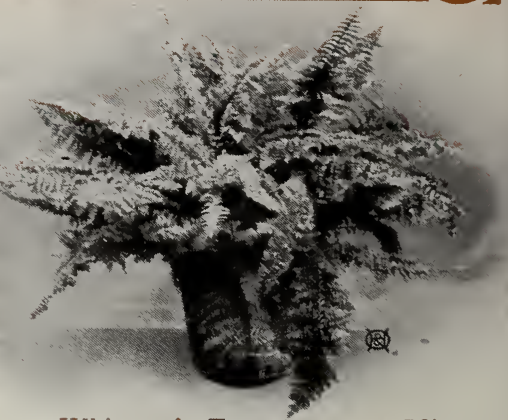

Wbitman's Fern (see page 79)

\section{DISTINCTIVE PALMS}

Cocos Weddelliana. The most graceful of the smaller-growing $\mathrm{PaIms}$. Admirable for fern-dishes and table decorations. 35 cts. to $\$ 1.50$.

Kentia Belmoreana. The Kentias are the hardiest PaIms. They are of slow growth and are less affected by the dust and dry atmosphere of the house than any others. This variety is of a dwarf, spreading habit with fine rich foliage. $\$ 1$ to $\$ 10$. Large specimens in tubs. Prices will be quoted on application.

PANDANUS Veitchii (Screw Pine). One of the finest decorative plants for the house, with long, gracefully curving leaves, broadly striped with creamy white on a green ground. This variety makes a charming table decoration when its pot is hidden by vines or other greenery. The Pandanus requires about the same treatment as the dracæna, but is better adapted to culture in the living-room than is that plant. $\$ 1.50$ to $\$ 5$.

\section{HANGING-BASKETS}

For a beautiful and artistic effect, nothing equals a well-filled basket of Ferns and other decorative plants. Baskets filled with these grow more beautiful each week, and are more satisfactory than with blooming plants. $\$ 2$ to $\$ 10$.

\section{HYDRANGEA HORTENSIS OTAKSA}

This type of Hydrangea is used for porch-steps, or it can be set along walks, drives, etc. It is not hardy and must be kept in tubs, which can be placed in large vases, and there is nothing quite so effective for decorative effect, as the blooming season extends through most of the summer. After through blooming, cut back and set tubs away in a cool part of the cellar. In the spring, when the weather begins to warm, give a good soaking of water and continue watering freely until they start to grow.

This is the variety that is used so extensively at the Atlantic seashore resorts, producing immense heads of

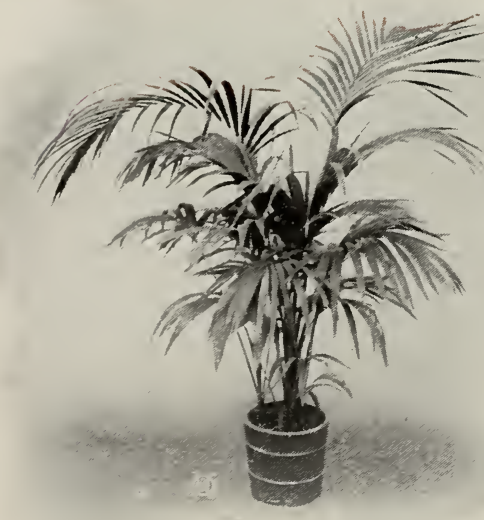

Palm (Kentia Belmoreana) flowers, usually pink in color, throughout the entire summer. We have a grand lot of plants specially prepared for summer flowering that will make a handsome display. Specimens in tubs, \$3 to $\$ 10$.

Our House Plants, as shown on this and other pages, are of the same "H. \& O. Quality", wbicb distinguishes all our productions, adding mucb beauty to a bome.

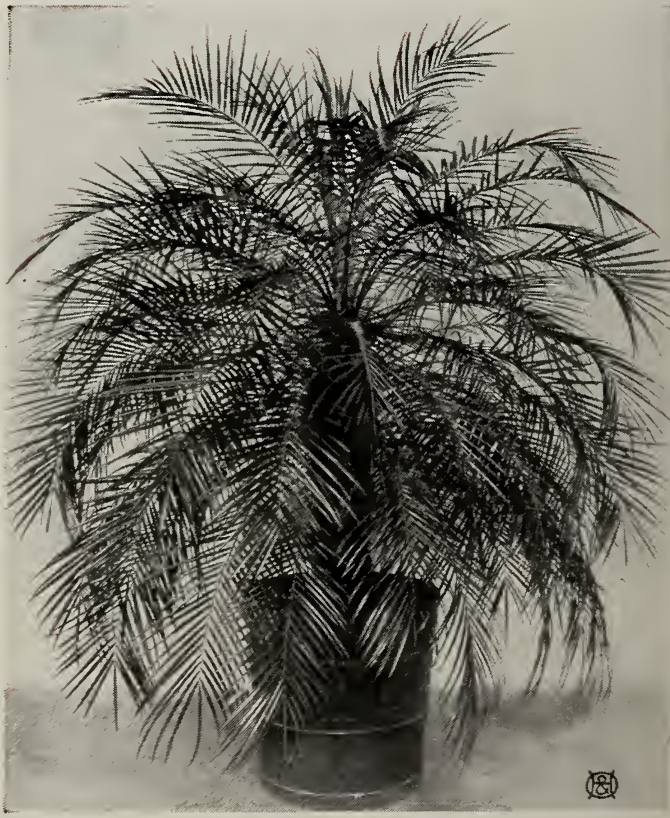

Pbonix Robelenii 


\section{(1902) SAINT PAUL,MINN.. (1906)}

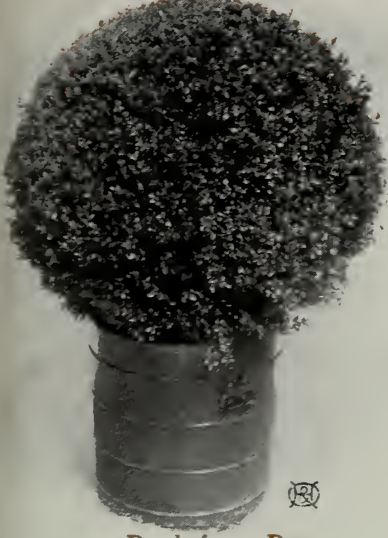

Busb-form Box

\section{BAY AND BOX TREES}

$\longrightarrow$ OR decorative purposes, these stately ever4 greens have attained great popularity. Every formal garden-Colonial or Italianand every home or building constructed along classic lines, requires the Bay and the Box to complete their dignified settings. Adapted for roofgardens, hotel and theater foyers, store openings, and large halls for public gatherings, wherever formal decorations can be introduced effectively. The trees withstand cold to the frost-point, and dust and darkness.

Years of careful training in Europe have developed our very choice specimens, shaped in standard and pyramidal forms. We are pleased to suggest suitable settings to our customers. If there is a large hall, porch, piazza or terraces, entrances, steps, balustrade columns, or a formal garden, these trees are not only essential, but their dark green, thick, glossy foliage adds unusual attractiveness and quiet beauty to the entire picture.

There are many forms of these trees; the Bay trees are grown in pyramids, limbed from the tub up, tapering to a point, making a true-shaped pyramid.

\section{BAY TREES (Laurus nobilis)}

Purchasers desiring fine, well-shaped Bay trees at reasonable prices will do well to investigate or examine our stock, as we are the largest importers in the Northwest, and we have in stock at all times good qualities of all sizes including extralarge specimens.

\section{STANDARD FORM}

\begin{tabular}{|c|}
\hline 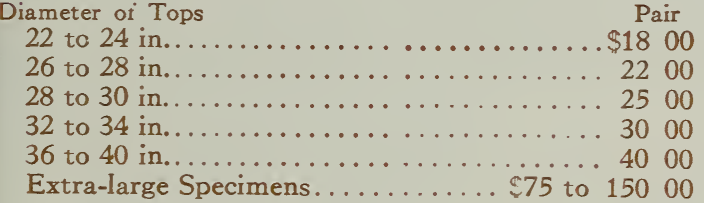 \\
\hline
\end{tabular}

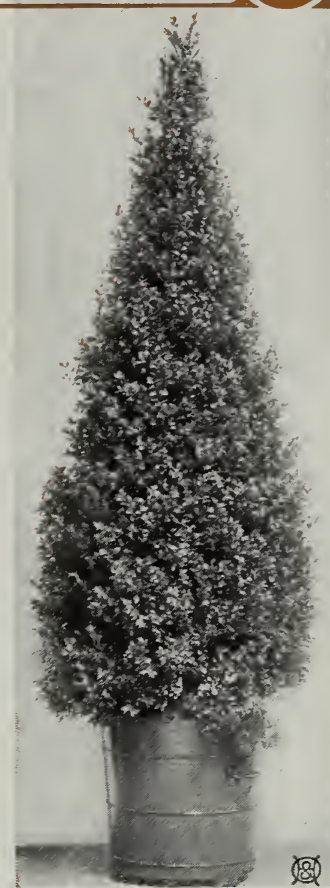

Pyramidal Box Tree

\section{BOX TREES}

These plants are sheared in compact, pyramidal and globe forms, and make very beautiful specimens. Box trees are desirable for the same purposes as the Bay trees, while not so expensive. Nothing is better for the open porch and formal garden, planted either in tubs or the open ground.

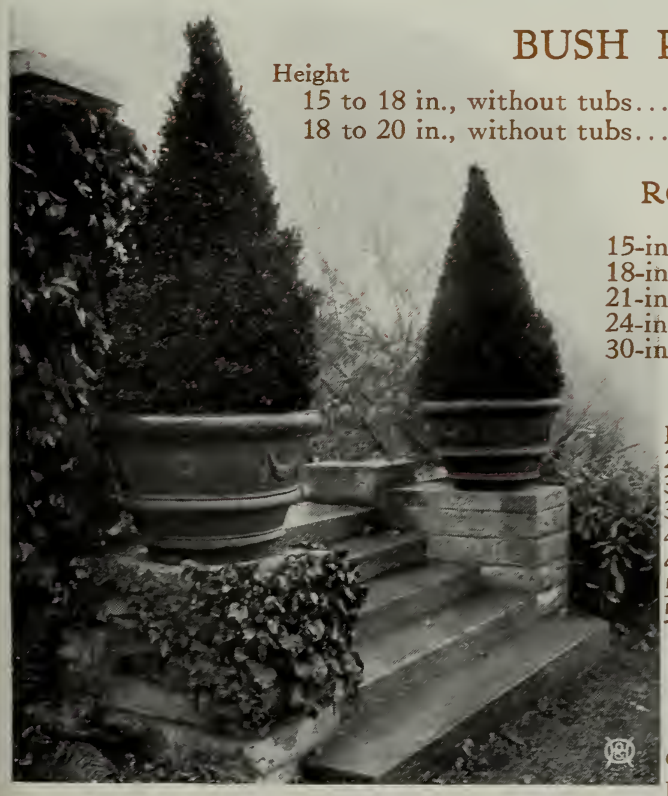

Pyramidal Box adds to the dignity of an entrance

\section{PYRAMIDAL FORM}

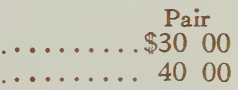

\section{SPECIMEN COLUMNS}

These are specially grown, and will be found to be the very finest obtainable. $\$ 125$ to $\$ 150$ per pair. 


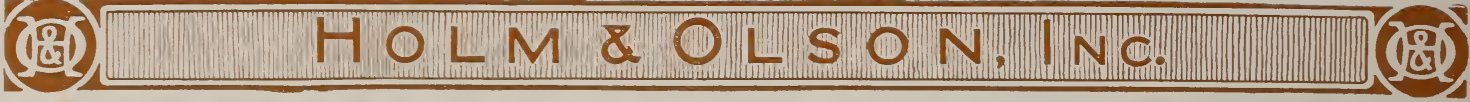

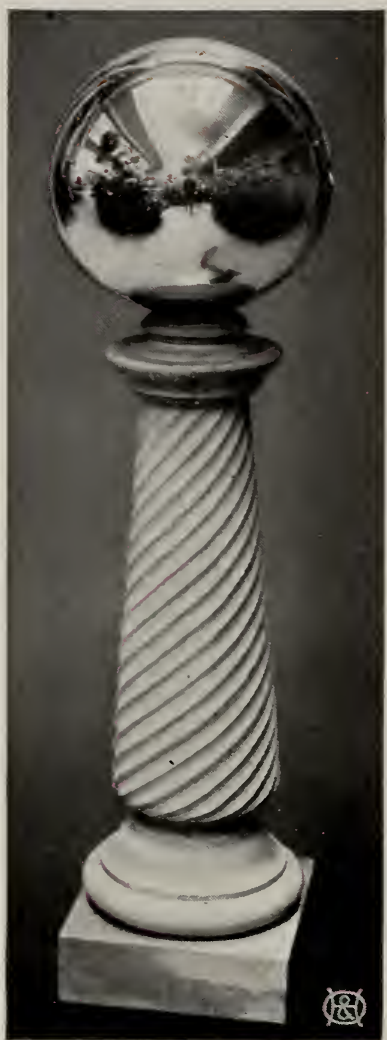

No. 508, Gazing-Globe

\section{GALLOWAY TERRA-COTTA}

The Galloway Potteries have the reputation of making the best product for garden material, and their designs are the very latest the market affords. We are their representatives in the Northwest, and we shall be pleased to send a fully illustrated catalogue on request.

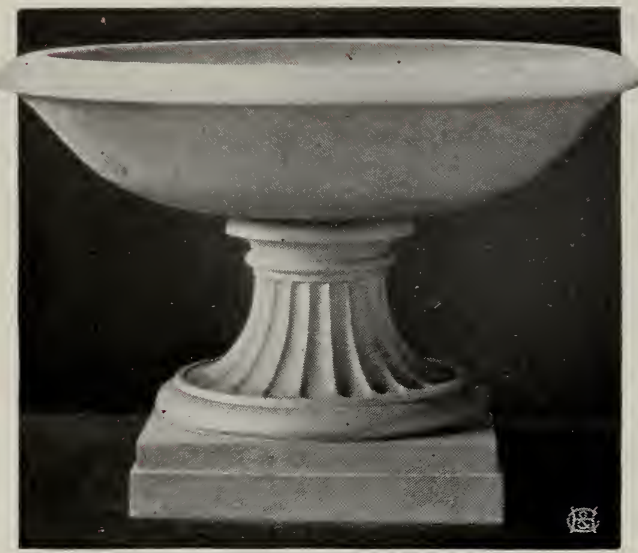

No. 571, Bird-Font

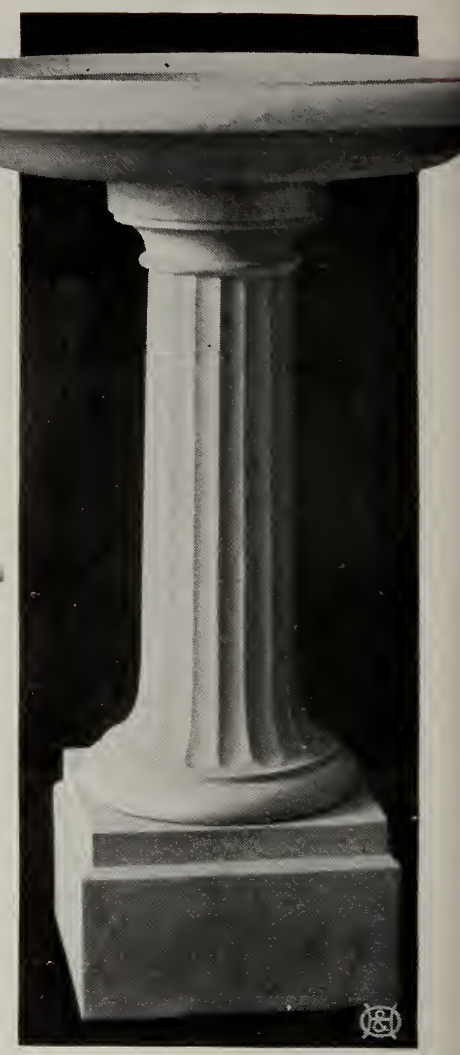

No. 547, Bird-Font

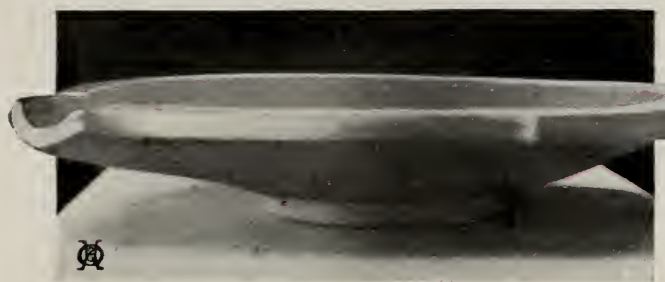

No. 547, Bird-Font. 36 inches high, 27 inches wide, Each $12 \frac{1}{2}$-inch base. Equipped with fountain connection.......................... 00 No. 571, Bird-Font. 15 inches high, 24 inches wide, 12 -inch base $\ldots \ldots \ldots$ inches high, 20 inches wide,

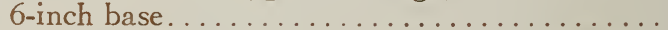

No. 304, Fountain. Figure of Boy and Goose. 21 inches high, 7-inch base............. 2200

No. 258, Bird-Font, 20 in. wide, $31 / 2$ in. bigb

No. 508, Gazing-Globe. 52 inches high, 12 -inch base. 4500

\section{POOLS, or LILY-PONDS}

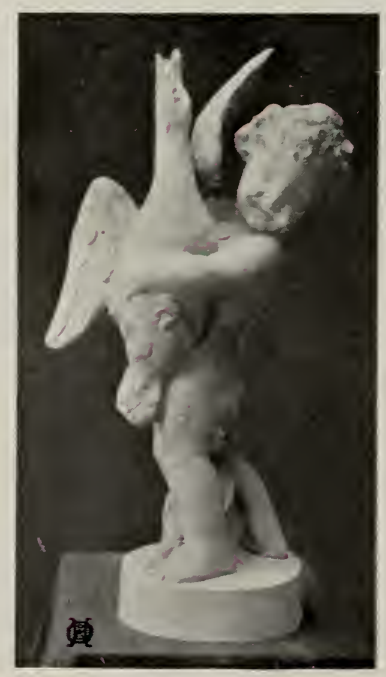

No. 304, Fountain Figure

These are constructed of reinforced concrete or brick, and can be designed to fit the location. We will make designs and specifiçations for them, with bid for construction.

It is a very simple problem to grow water-lilies and other water-plants in the
garden, and a pool can be made the chief feature of. the garden.

Even a small garden can well afford space for \&is $y$. a pool of this character, as the $\mathrm{b}$ e a u $\mathrm{t}$ if $\mathrm{ul}$ blooms, the aquatic plants,
and the goldfish are a continuous ure.

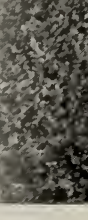

Concrete Lily-ponds make a cbarming spot in the garden 


\section{(10}

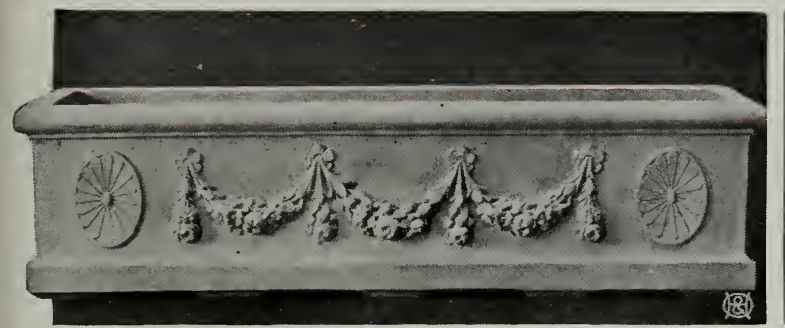

No. 557

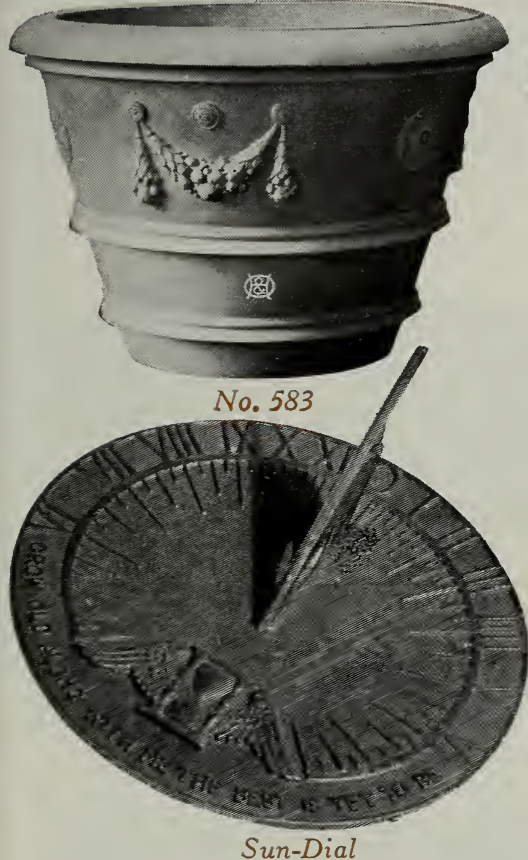

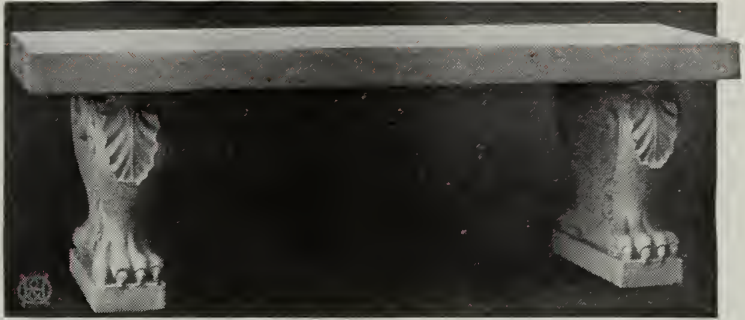

No. 191

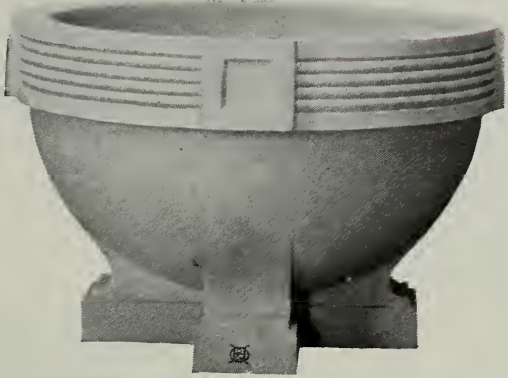

No. 551, Vase

BOXES AND VASES

No. 557, Flower Box. 9 inches high, Each $10 \times 34$ inches.............\$12 00 No. 319, Laurel Box. $91 / 2$ inches high, $9 \times 35$ inches.................
No. 191 , PaImetto Bench. Top 17

by 54 inches, 19 -inch base ...... 3000 No. 583, Lanti Vase. 21 inches high,

31 inches wide, 161/2-inch base. . . . 2700 No. 598, Flower Vase. $161 / 2$ inches

high, 23 inches wide, 11 -inch base. 1200 No. 376, Fruit-Border Vase. 11 inches high, 18 inches wide, 10-in. base. .

No. 378, Fruit-Border Vase. 15 inches high, 24 inches wide, 13-inch base. No. 551, Flower Vase. 12 inches high, 18 inches wide.

No. 513, Sheraton Vase. 14 inches high, 17 inches wide, 11/2-inch base.

\section{SUN-DIALS}

No. 202, Greek Doric. 37 inches high, 131/2-inch base, 14-inch top; complete with dial .

ANTIQUE CAST BRASS. Can be mounted on wooden or concrete

pedestals. No. 4. 123/4-inch diameter; round.................. 1400 No. 5. $81 / 2$-inch diameter; round .

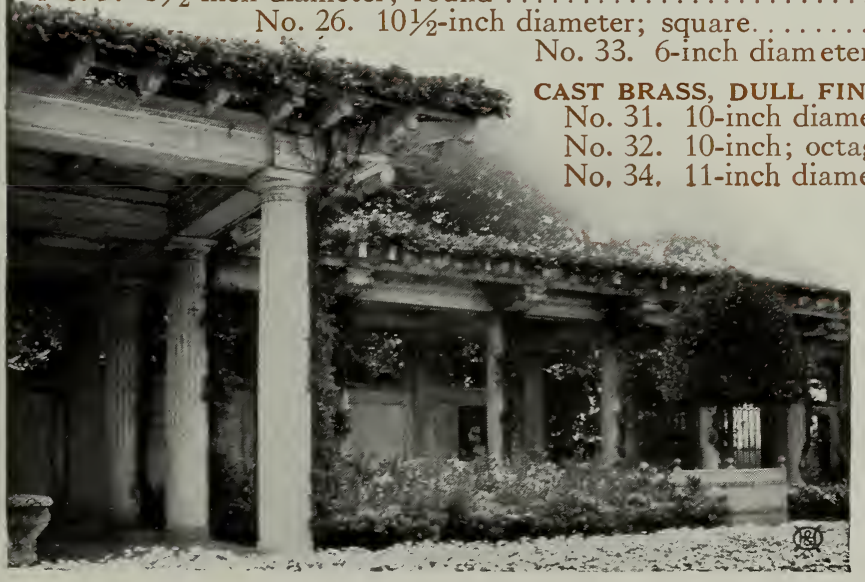

Concrete Pergolas are most impressive and lasting
1100

500

1600

750

750

650

1300

650

1000

1200

500 Pergola.

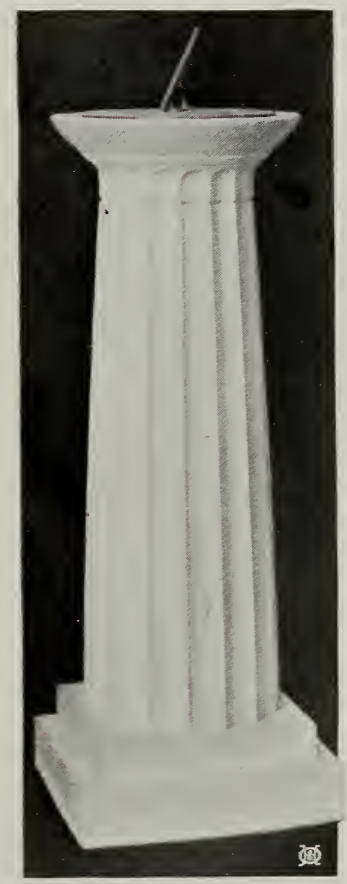

No. 202

\section{PERGOLAS}

The Pergola forms such an admirable covering for a favorite walk that its popularity is readily accounted for. Its very character suggests vines that will contribute to the picturesque and overcome the natural stiffness and uniformity.

The construction of Pergolas must conform to the building, and they vary in cost. The wooden post-and-beam effect costs from $\$ 5$ to $\$ 10$ per foot. We shall be pleased to submit designs for any style of 


\section{GREEN WICKER BOXES}

For House and Conservatory. Strong and durable; zinc-lined

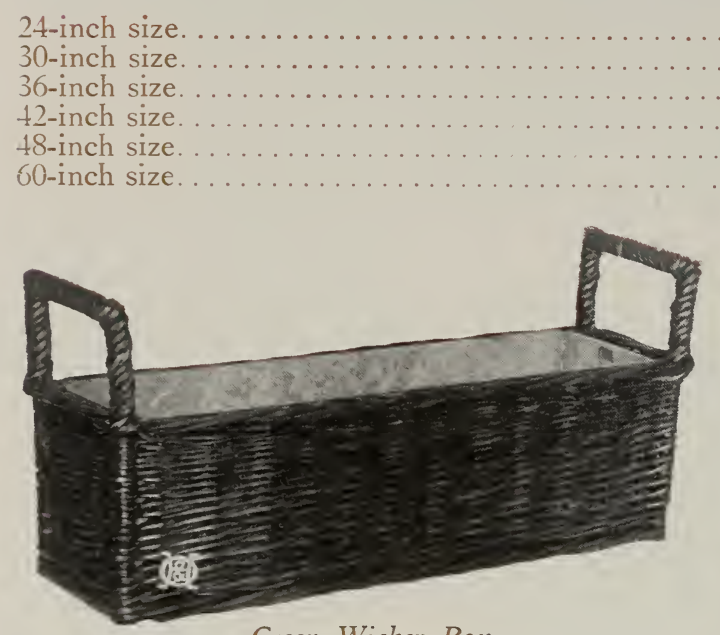

Green Wicker Box

\section{IDEAL VACUUM PORCH-BOXES}

An ideal self-watering porch- and window-box. This box is constructed on new principles, having double walls with an air space between them. This keeps the inner wall cool so the soil will not dry out and bake. It makes an ideal box for outside in summer and inside in winter. On account of its construction you cannot over-water, and surplus water will not run out on the floor. Moreover, it is self-watering and needs attention only once or twice a week. All boxes are $81 / 4$ inches wide by $61 / 2$ inches d’eep.

24 inches long

30 inches long.

36 inches long.

42 inches long.

48 inches long.

60 inches long.

If these are wanted filled, we will fill them nicely with appropriate flowering plants and vines at $\$ 1$ per foot.

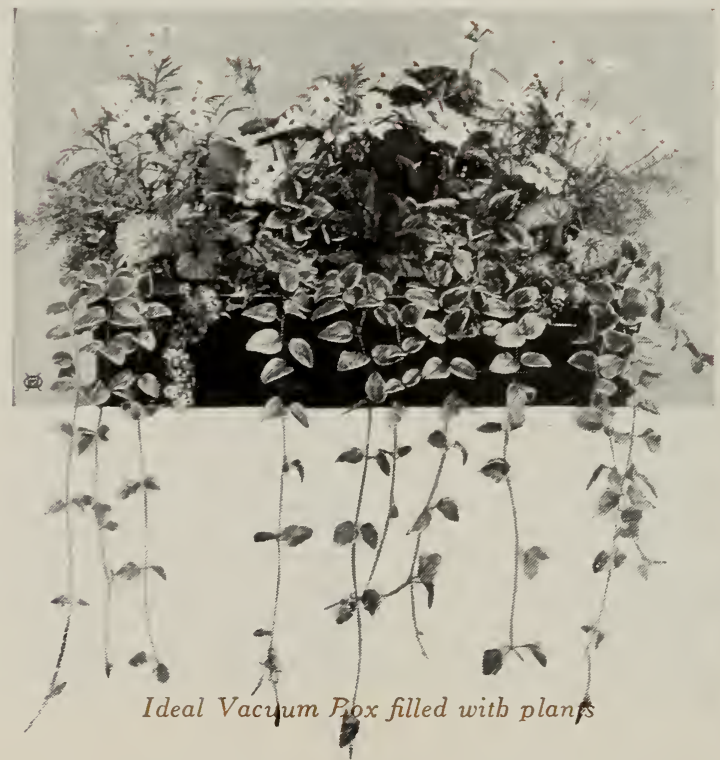

Without handles With handles. Each
.$\$ 350$

450

650

750

850

1050

GREEN WICKER BOXES ON LEGS

Long High Each 24 in... . 30 in. . \$8 00 30 in... 30 in... 950 36 in... 30 in... 1100

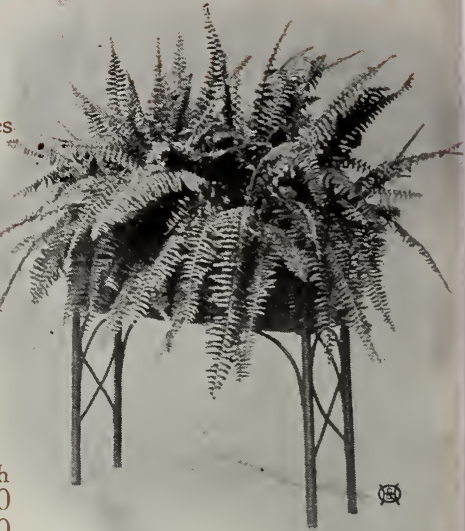

Wicker Box, with ferns
Especially pretty when filled with ferns. Should the filled box be desired, add \$2 per lineal foot.

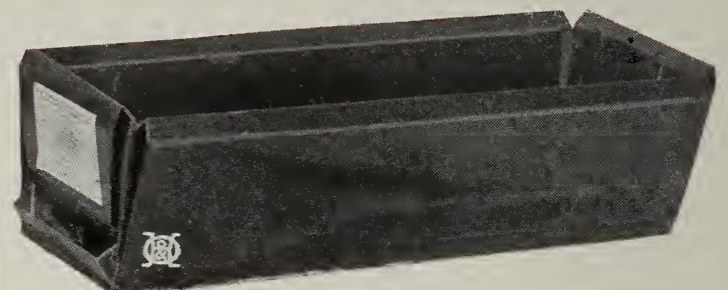

Ideal Vacuum Porch-Box

\section{BIRD-HOUSES}

Our stock of Bird-Houses is Iarge. We have them from 75 cts. to $\$ 15$ each. Write for our illustrated list on Bird-Houses.

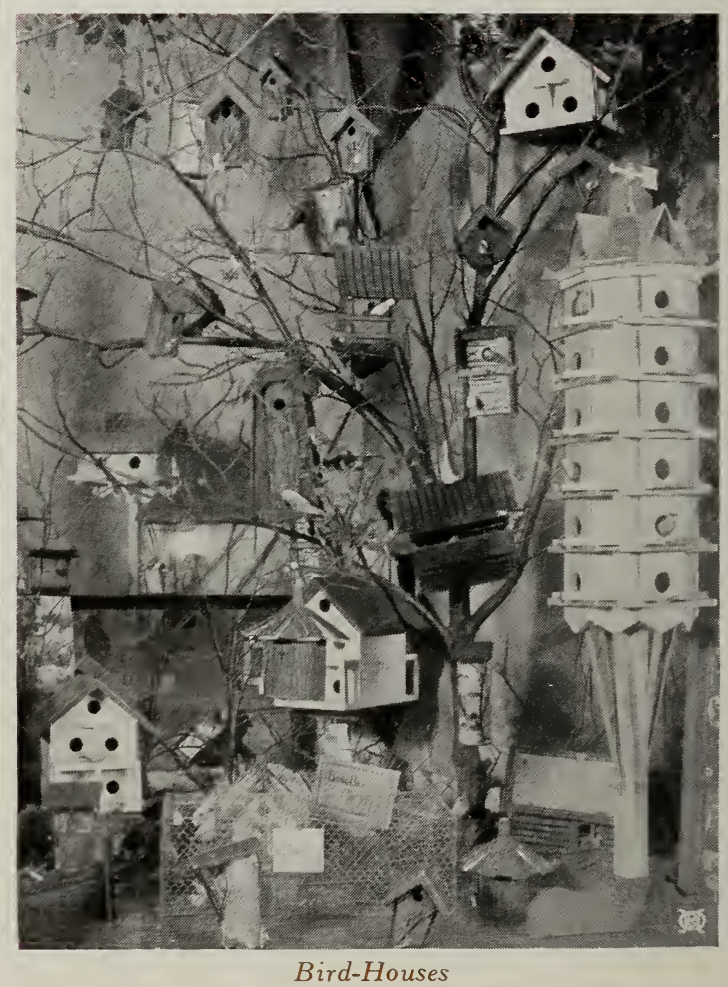




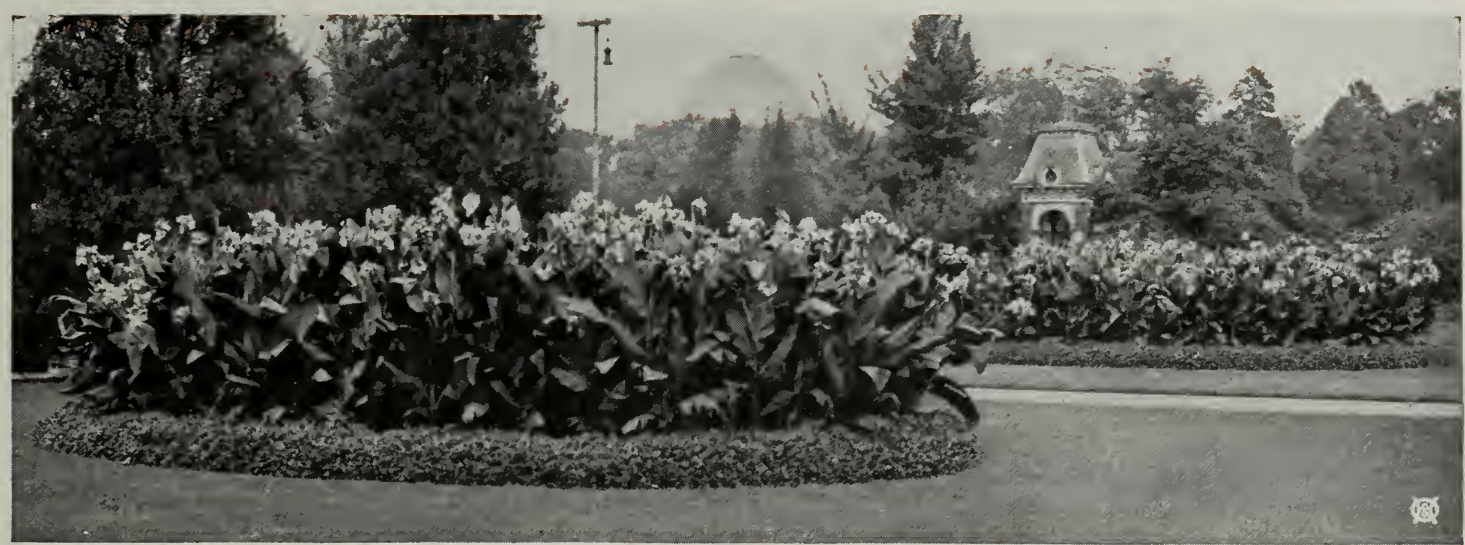

Our strong-growing Cannas will soon form a bed like this

\section{CANNAS}

We call attention to our fine stock of Cannas-offered in best varieties, 4-inch pots, 12 to 18 inches high, ready to plant, and saving much time. AIl our stock is grown in this way. We make a specialty of choice bedding plants, and beg to refer to thousands of the most beautiful Iawns in the Twin Cities and other cities in the Northwest, where our plants are used.

Allemania. 5 feet. Orchid-flowering; green foliage. Outer petals are bright scarlet, with a broad yellow border, the inside beautifully mottled and variegated.

Austria. 5 feet. Orchid-flowering; green foliage. Large flowers, 6 to 7 inches across; pure golden yellow.

Beacon. 4 to $4 \frac{1}{2}$ feet. Green foliage. Moderatesized flowers of rich cardinal, in great masses.

Brilliant. 4 feet. Green foliage. Pure golden yellow flowers with two curling petals of frery red.

Buttercup. 3 feet. Green foliage. Flowers pure buttercup-yellow. The best yellow Canna in existence.

Comte de Sachs. 4 feet. Green foliage. Flowers are clear crimson-scarlet, very bright, and borne well above the foliage. 40 cts. each, $\$ 4$ per doz.

Express. $21 / 2$ feet. Green foliage. Flowers bright scarlet-crimson. Excellent for bordering.

Firebird. 3 feet. A remarkable Canna with perfectly formed flower, 7 to 8 inches in diameter, of a brilliant cardinal-red. The foliage is heavy and beautiful. Requires rich soil for best results. 50 cts. each, $\$ 5$ per doz.

Florence Vaughan. $31 / 2$ feet. Green foliage. Flowers rich golden yellow, thickly spotted with bright red. A standard variety for planting in masses for solid color.

Gladiator. 5 feet. Green foliage. Flowers intense yellow, spotted with bright red. This is one of the most remarkable varieties we have ever introduced. $50 \mathrm{cts}$. each, $\$ 5$ per doz.

Hungaria. $3 \frac{1}{2}$ feet. Green foliage. Flowers large and borne in trusses of enormous size, well above the foliage. Color is La France pink, with satiny sheen. 50 cts. each, $\$ 5$ per doz.

J. D. Eisele. $31 / 2$ feet. Green foliage. Flowers bright vermilion-scarlet overlaid with orange. A fine bedder.

Julius Koch. 4 feet. Dark green foliage. Flowers composed of four broad, well-rounded, Iarge petals and of the most brilliant blood-red. $50 \mathrm{cts}$. each, $\$ 5$ per doz.

King Humbert. 4 feet. Bronze foliage, with brownish green stripes, large, thick and leathery. Flowers large; bright orange-scarlet, streaked with crimson. 30 cts. each, $\$ 3$ per doz.

Louisiana. 3 feet. Green foliage, edged with bronze. Flowers are very large and silky, borne well above the foliage. Color is vivid scarlet; one of the finest orchid-flowering Cannas.

Meteor. (Wintzer's.) 5 feet. Green foliage. One of the most brilliant Cannas, of a rich, glowing, deep crimson. Each plant produces five or six trusses of bloom, which flower constantly all summer. Undoubtedly our best red, and one that will always be in the front rank. 50c. each, $\$ 5$ per doz.

Minnehaha. 4 feet. Bronze foliage. Blossoms are extra large and borne in great clusters; petals are long, gracefully curved and have wavy edges. The color reminds one of a dainty, transparent sea-shell, deepening through shades of gold and cream to a center of peachblow-pink. The foliage harmonizes charmingly with lovely, delicately colored flowers. $50 \mathrm{cts}$. each, $\$ 5$ per doz.

Mont Blanc Improved. $31 / 2$ feet. Green foliage. Almost pure white. This is the predecessor of Blanche Wintzer, introduced in 1913. For ten years it has held the field as the largest, near-white Canna in existence.

Prince Wied. 3 feet. Dark green foliage. Flowers of extra size, borne in massive clusters, and of a fiery, velvety blood-red. One of the best red Cannas of dwarf growth. 50 cts. each, $\$ 5$ per doz. Souvenir d'Antoine Crozy. 3 feet. Green foliage. Beautiful red, bordered with golden yellow. Very popular.

Wawa. 3 feet. Green foliage. The color of this Canna is an indescribably lovely soft pink, and the medium-sized flowers are borne in great profusion on strong, upright stems.

West Grove. $41 / 2$ feet. Green foliage. Flowers are Iarge, well formed, and the color is an attractive, rich coral-pink.

Wyoming. 7 feet. Purple foliage. One of the most majestic Cannas. Blossoms orange-colored, true orchid-shape, with large, rounded petals, that flutter in the breeze like silken flags.

Prices of Cannas, except where noted, 4-inch pot-plants, I2 to I8 inches high, $30 \mathrm{cts}$. each, $\$ 3$ per doz. 

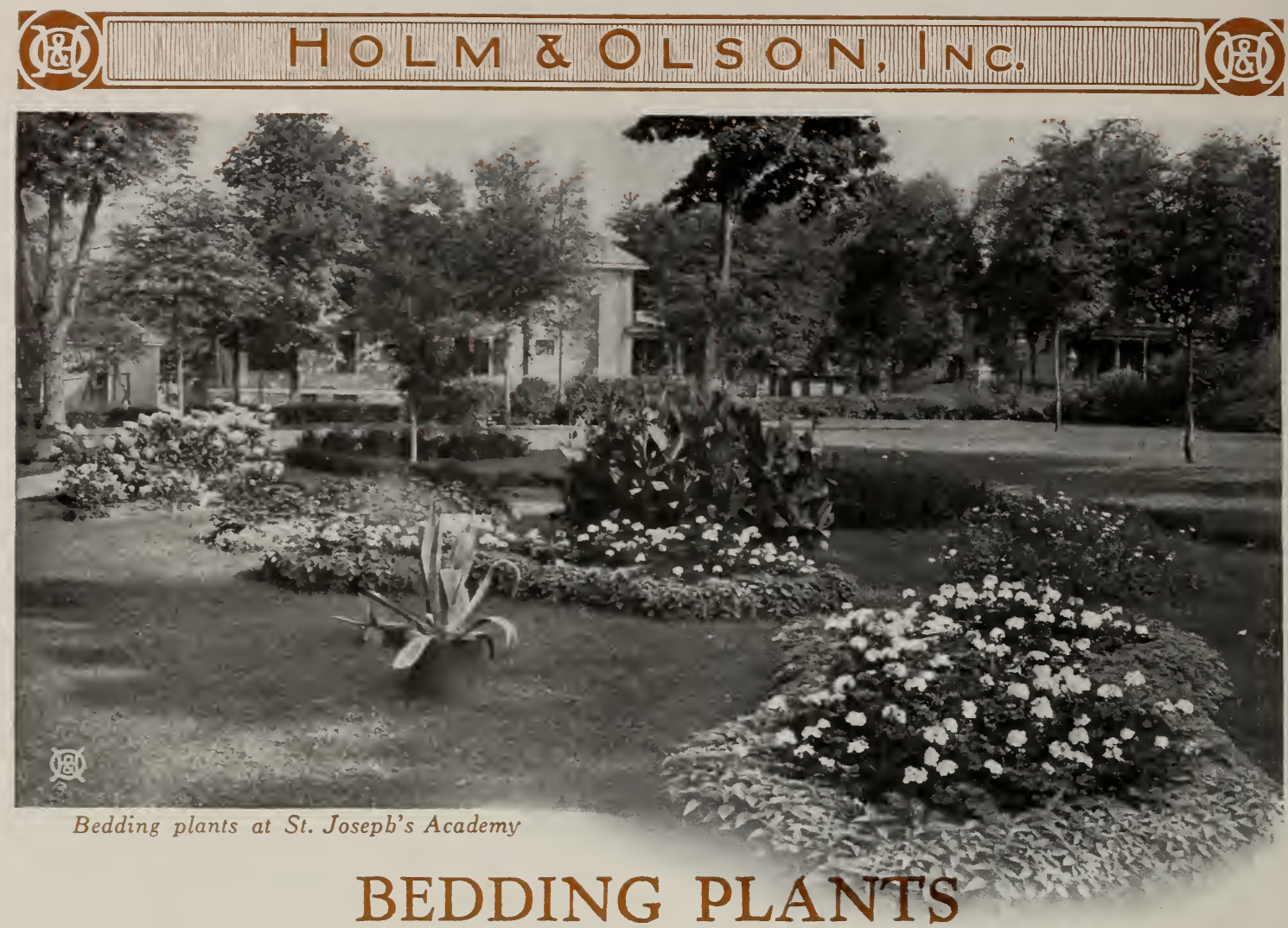

Our list of varieties has been carefully revised, and only plants of value and that are easily grown are submitted for your selection. Our success in growing fine plants is noteworthy, and our plants are known throughout the entire Northwest as being the best that can be produced, and always give entire satisfaction. Varieties marked with a star $(*)$ are especially adapted for bedding purposes. Those marked with two stars $(* *)$ are best for borders. All marked with a double dagger $(\ddagger)$ will be in bud or bloom at time of shipping. Full and complete list of Bedding Plants Ready May 1

Abutilon (Flowering Maple).* White, yellow, pink.
3-inch pots, $15 \mathrm{c}$. each, $\$ 1.50$ per doz., $\$ 12$ per 100. 3-inch pots, 15c. each, $\$ 1.50$ per doz., $\$ 12$ per 100.
A., Variegated. 3-inch pots, 10c. each, \$1 per doz. Achyranthus.** Red-and-white leaves. 21/2-inch pots, 10 cts. each, $\$ 1$ per doz., $\$ 8$ per 100 .

Ageratum, Blue Perfection.* Bright blue. 31/2inch pots, $10 \mathrm{cts}$. each, $\$ 1$ per doz., $\$ 8$ per 100 .

Alternanthera.** Dainty foliage plant for carpet bedding. $21 / 2$-inch pots, 60 cts. per doz., $\$ 4$ per 100 .

Alyssum, Little Gem.** Dwarf; for edging. 21/2inch pots, 10 cts. each, 75 cts. per doz., $\$ 6$ per 100 .

Antirrhinum (Snapdragon).* Pink, white, red, yellow. 2-in. pots, 50 cts. per doz., $\$ 4$ per 100.

Asters. One of the most popular flowering plants. Strong seedlings, 25 cts. per doz., \$2 per 100.

Begonia Rex. Begonias are invaluable for house culture; they make excellent plants for baskets or vases. 4 -inch pots, 20 cts. each, $\$ 2$ per doz.

B. gracilis luminosa.* Pink, one of the choicest bedding sorts. 3-inch pots, 10c. each, \$1 per doz.

B., Gloire de Chatelaine.* A brilliant pink bedding sort. 3-inch pots, 10 cts. each, \$1 per doz.

B., Vernon.** Flowers beautiful, deep rose. 3inch pots, 10 cts. each, \$1 per doz., \$8 per 100 .

B., Tuberous-rooted.* Dormant bulbs, 25 cts. each, \$2.50 per doz. Plants, $41 / 2$-inch pots, 35 cts. each, \$4 per doz.

Caladium (Elephant's Ear).* A fine, subtropical plant. 4-inch pot-plants, 12 to 18 inches high, 40 cts. each, $\$ 4$ per doz.

Calendula, Orange King (Pot Marigold).* 3-inch pots, 10 cts. each, \$1 per doz., \$8 per 100 .

Candytuft, White.** Indispensable for cutting. $31 / 2$-inch pots, 15 cts. each, $\$ 1$ per doz., $\$ 7$ per 100 .

Cannas. See page 85 .
Cardinal Climber (Quamoclit bybrida). A beautiful and brilliant annual climber; a strong and rapid grower, attaining a height of 30 feet or more; fernlike, Iaciniated foliage; a blaze of frery cardinalred flowers from midsummer till frost. $25 \mathrm{cts}$. each, $\$ 2.50$ per doz.

Carnations. f Red, pink and white. 21/2-inch pots, 10 cts. each, $\$ 1$ per doz., $\$ 8$ per 100 .

C., Margaret.* Assorted colors. 2-inch pots, 5 cts. each, 50 cts. per doz., \$4 per 100.

Celosia (Cockscomb).* New plumed varieties. 2 inch pots, 10 cts. each, 75 cts. per doz., \$6 per 100.

Centaurea candidissima (Dusty Miller).** Silvery white leaves. 21/2-inch pots, $10 \mathrm{cts}$. each, 75 cts. per doz., \$6 per 100 .

Chrysanthemums. Our list contains the most improved sorts. $2 \frac{1}{2}$-in. pots, 10 c. each, $\$ 1$ per doz.

Cobæa scandens (Cup-and-Saucer Vine). Rapidgrowing climber. $31 / 2$-in. pots, 20 c. each, $\$ 2$ per doz.

Coleus.** Separate or mixed colors. 21/2-inch pots, 75 cts. per doz., \$6 per 100.

C., Mammoth-leaved. * 10 cts. each, $\$ 1$ per doz. Cosmos, Early Dawn.* Large-flowering; very early; lavender. 3-inch pots, 10 cts. each, $\$ 1$ per doz., $\$ 8$ per 100 .

Dracæna. Good for center of beds or vases. 5-inch pots, 75 cts. each; 6 -inch pots, $\$ 1$ each.

Echeveria (Hen-and-Chickens). ${ }^{* *}$ Used for carpet bedding. 10 cts. each, \$1 per doz., \$8 per 100 .

Feverfew.* Double, white flowers. 4-inch pots, 25 cts. each, $\$ 2.50$ per doz.

Forget-me-not. * 3-inch pots, 15 cts. each, $\$ 1.50$ per doz.

Fuchsias. $\ddagger$ For window pot-plants or shady spots in the garden. 4 -inch pots, 20 cts. each, $\$ 2$ per doz. 


\section{BEDDING PLANTS. continued} Geraniums.* Our selection of the best varieties.
4 -inch pots, 20 cts. each, $\$ 2$ per doz., $\$ 15$ per 100 . G., Ivy-leaf.* Desirable for porch- or window-
boxes. 4 -inch pots, 25 cts. each, $\$ 2.50$ per doz.

G., Nutmeg.* Scented foliage. 3 -inch pots, 20 cts. each, $\$ 2$ per doz.

G., Rose, or Sweet-scented. 3-inch pots, 20 cts. each, $\$ 2$ per doz.

G., Ruby.* Bright cardinal-red. The best geranium for vase and window-boxes; new. 4-inch pots, 25 cts. each, $\$ 2.50$ per doz.

G., Scarlet Bedder.* Bright; free-flowering; immense trusses. 4 -in. pots, 25 c. ea., $\$ 2.50$ per doz.

G., Silver-leaved.* Leaves edged white, $21 / 2$-inch pots, 10 cts. each, $\$ 1$ per doz., $\$ 8$ per 100.

G., Skeleton-leaf.* Deeply cut, fragrant foliage. 3-inch pots, 20 cts. each, $\$ 2$ per doz.

Heliotrope.* Small, fragrant, blue flowers in clusters. 15 cts. each, $\$ 1.50$ per doz.

Ice Plant. Trailing annual. $10 \mathrm{cts}$. each, $\$ 1$ per doz. Ivy, English. 4-inch pots, 25 cts. each, $\$ 3$ per doz.; large plants in 6-inch pots, 75 cts. to $\$ 1.50$ each.

I., German. Fast-growing; good for baskets. 31/2-inch pots, $20 \mathrm{cts}$. each, $\$ 2$ per doz.

Lantana. ${ }^{*} 3$-inch pots, 10 cts. each, $\$ 1$ per doz.

Lilies. Potted plants, nicely started, from 8 to 10 inches, of the following: Album, Auratum, Rubrum. 6-inch pots, 50 cts. each, $\$ 5$ per doz.

Lobelia.** SmaIl, deep blue flowers. $2 \frac{1}{2}$-inch pots, 10 cts. each, \$1 per doz., \$8 per 100.

L., Trailing. $21 / 2$-inch pots, 10 cts. each, $\$ 1$ per doz.

Lonicera (Honeysuckle). Fine for boxes or vases. 4 -inch pots, 25 cts. each, $\$ 3$ per doz.

Marguerite Daisy.*‡ Standard sorts, white and yellow. 4-inch pots, 20 cts. each, \$2 per doz.

M., Queen Alexandra.* White flowers $2 \frac{1}{2}$ to 3 inches wide. 4 -inch pots, 20 cts. each, $\$ 2$ per doz.

M., Mrs. F. Sanders.* $\ddagger$ Double, pure white, 3 inches in diameter. 4 -inch pots, 25 cts. each, $\$ 2.50$ per doz.

M., Yellow (Paris Daisy).*‡ 4-inch pots, 20 cts. each, $\$ 2$ per doz.

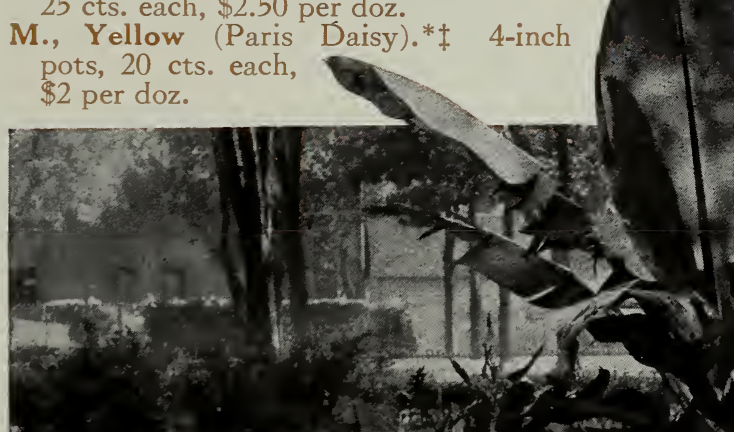

nonette. * 31/2-in. pots, 10c. each, $\$ 1$ per doz.

Minneapolis Vine. 4-in. pots, 20c. each, $\$ 2$ per doz.

Moonflower Vine (Ipomoa maxima). Pure white flowers. 4-inch pots, 20 cts. each, $\$ 2$ per doz.

Nasturtium, Dwarf Mixed.* 21/2-inch pots, 10 cts. each, \$1 per doz., \$8 per 100 .

Pansies, Mixed.**‡ 50 cts. per doz., $\$ 3$ per 100 .

Pelargonium (Lady Washington Geranium). 4 -inch pots, 20 cts. each, $\$ 2$ per doz.

Petunias, Single.* $\ddagger 31 / 2$-inch pots, $15 \mathrm{cts}$. each, $\$ 1.50$ per doz.

P., Single, Large-flowering, Fringed.* 4-inch pots, 20 cts. each, $\$ 2$ per doz.

P., Double. * Fine sorts. 4-inch pots, 25 cts. each, $\$ 2.50$ per doz.

Phlox Drummondii.* 75 cts. per doz., \$5 per 100. Pyrethrum aureum (Golden Feather). * 21/2-inch pots, 10 cts. each, \$1 per doz., \$8 per 100 .

Ricinus (Castor Bean). This plant has enormous leaves. 4 -inch pots, 20 cts. each, $\$ 2$ per doz.

Salpiglossis.* A great favorite among the annuals. 2 -inch pots, 50 cts. per doz., \$4 per 100.

Salvia, Bonfire (Scarlet Sage). ${ }^{*}$ Effective for bedding. 4-inch pots, 15 cts. each, $\$ 1.50$ per doz.

S., Zurich.* New. Dwarfest and earliest; constantly in bloom. 4 -inch pots, 15 cts. each, $\$ 1.50$ per doz. Scabiosa (Mourning Bride).* The beautiful flowers come in all shades, and borne on long stems. 2 -inch pots, 50 cts. per doz., $\$ 4$ per 100 .

Stock, Ten Weeks (Gilliflower).* 3-inch pots, 10 cts. each, $\$ 1$ per doz., $\$ 8$ per 100 .

Tradescantia (Wandering Jew). Green and variegated. 4 -inch pots, 15 cts. each, $\$ 1.50$ per doz.

Verbenas, Assorted Colors.** Free bloomer. 21/2-inch pots, 10 cts. each, $\$ 1$ per doz., $\$ 8$ per 100 .

V., Lemon. Pale green fragrant foliage. 4-inch pots, 25 cts. each, $\$ 2.50$ per doz.

Vinca, Variegated. For vases or for trailing over the edge of window-boxes. 31/2-inch pots, $25 \mathrm{cts}$. each, $\$ 2.50$ per doz.

V., Green. 4 -inch pots, 25 cts. each, $\$ 2.50$ per doz. Ainnias.* Popular summer-flowering

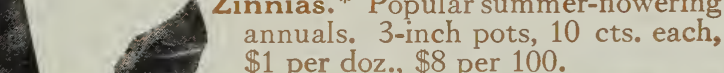
y $: \$ 1$ per doz., \$8 per 100

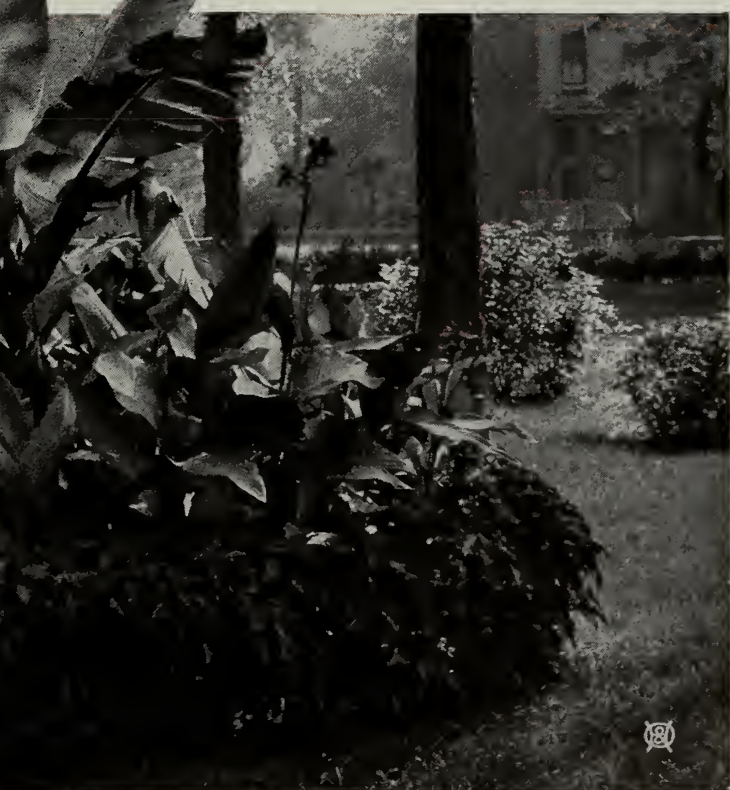

The kind of ornamental planting possible wrtb our Bedding Plants-Coleus, Cannas, ete. 


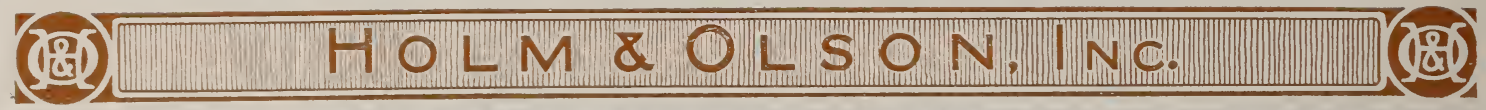

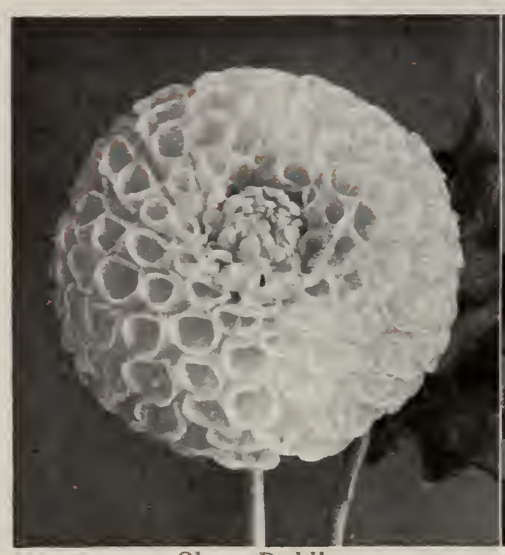

Sbow Dablia

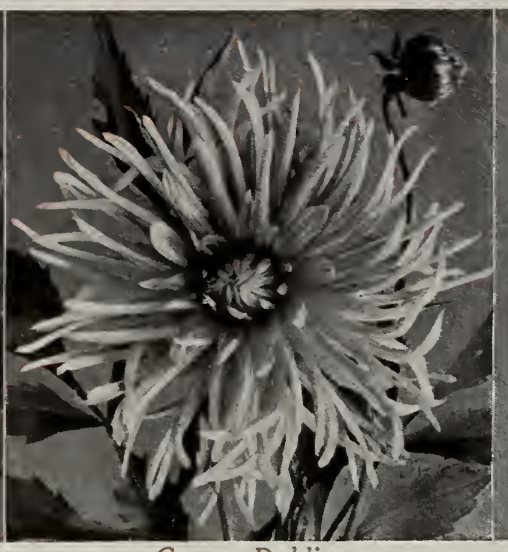

Cactus Dablia

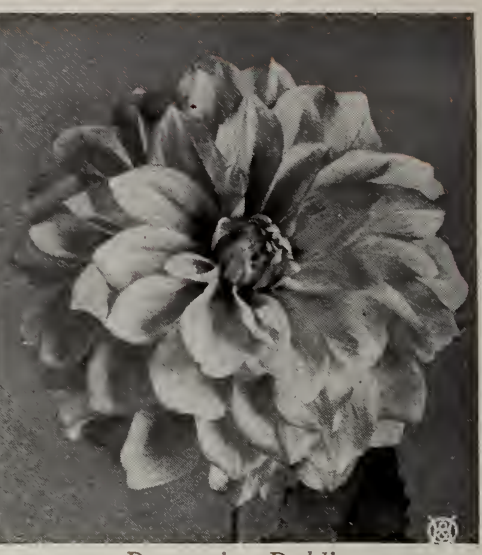

Decorative Dablia

\section{DAHLIAS}

Cultural Notes.-Select a well-drained position, where they will receive the benefit of the sun the greater part of the day. As to soil, they are not so particular, except that it should not contain too much clay; should such be the case, add coarse sand or coal-ashes. The soil must be worked deep and a good application of fertilizer added. Stable manure is the best.

The planting of dormant bulbs in this vicinity should be about May 15 to 25 . Green or growing plants should not be set until after all danger of frost is over, which is about May 25.

Special List. About April 1 we will issue a Special List of Dahlias, which will include the best new sorts and the desirable standards. Our collection of Dahlias is the Iargest ever offered in the West.

\section{CACTUS DAHLIAS}

This type of Dahlia is characterized by Iong, narrow, pointed and twisted petals, giving the layered flower a very striking appearance.

Egir. Rich, warm cardinal-red; twisted petals. Countess of Lonsdale. Pleasing blending of salmon-pink and amber. Free-blooming.

Earl of Pembroke. Bright plum.

Else. Beautiful yellow center, deep rose at tips.

Flora. A true white; large flowers on strong stems. Floradora. Blood-red; a remarkably free bloomer. General Butler. Rich velvety maroon, white tips. Kriemhilde. Brilliant pink, shading to white. Master Carl. Bright amber; perfect flower. Prince of Yellows. Rich canary-yellow.

Standard Bearer. Rich scarlet; free bloomer. Any of the above varieties, $30 \mathrm{cts}$. each, \$3 per doz., $\$ 20$ per 100. One each of the above for $\$ 3$

\section{SHOW DAHLIAS}

The following have the large, round, full-flowered characteristics of the Show class. They are either solid colors, edged or tipped lighter or darker.

A. D. Livoni. Fine clear pink; free-flowering and perfect form. 25 cts. each, $\$ 2.50$ per doz.

Grand Duke Alexis. Ivory-iwhite; Iarge, massive flower, tinted rose. $25 \mathrm{cts}$. each, $\$ 2.50$ per doz.

Princess Victoria Louise. Pure canary-yellow. 20 cts. each, \$2 per doz.

Queen of the Yellows. Clear primrose-yellow; of fine form. 20 cts. each, \$2 per doz.

Red Hussar. Brilliant cardinal-red; of perfect form. 20 cts. each, \$2 per doz.

Storm King. Very early; profuse bloomer and one of the best whites. 20 cts. each, \$2 per doz.

Snow Queen. Fine white, with Iarge flower. $25 \mathrm{cts}$. each, $\$ 2.50$ per doz.

One each of the above seven varieties for $\$ \mathbf{I} .40$

\section{DECORATIVE DAHLIAS}

This class comprises those that depart from the formal rounded type of the Show class, but do not have the twisted petals of the Cactus type.

C. W. Bruton. Bright yellow; one of the best. 20 cts. each, $\$ 2$ per doz.

Jack Rose. Brilliant crimson-red. 25 cts. each, $\$ 2.50$ per doz.

Mme. Van den Dael. Soft rose center, shading to white. 25 cts. each, $\$ 2.50$ per doz.

Orange King. Rich orange-scarlet. 20 cts. each, $\$ 2$ per doz.

Perle (Perle de Ia Tete d'Or). Glistening pure white; fine for cut-flowers. 20 cts. each, $\$ 2$ per doz.

Souvenir de Gustave Douzon. Brilliant orangescarlet; free-bloomer. 25 cts. each, $\$ 2.50$ per doz.

Sylvia. Soft pink center, shading to white; fine for cutting. 20 cts. each, $\$ 2$ per doz.

Wm. Agnew. A rich, dazzling carmine-red. 20 cts. each, $\$ 2$ per doz.

One each of the above eight varieties for $\$ \mathbf{1 . 5 0}$

\section{NEW CENTURY SINGLE DAHLIAS}

These are of the free-branching habit, flowering early and profusely throughout the season. Flowers 4 to 6 inches across, on long stems.

Crimson Century. Rich, velvety crimson.

Pink Century. Delicate, soft pink.

Scarlet Century. Brilliant scarlet.

Twentieth Century. Rosy crimson, the flowers change lighter as the season advances.

White Century. Pure white, with large petals. Price of the above Single Dahlias, $25 \mathrm{cts}$. each, \$2.50 per doz. One each of the above five varieties for $\$ 1.15$

\section{DAHLIAS IN FINE MIXTURE}

Comprising many of the very best varieties. 15 cts. each, $\$ 1.50$ per doz., $\$ 10$ per 100 . 

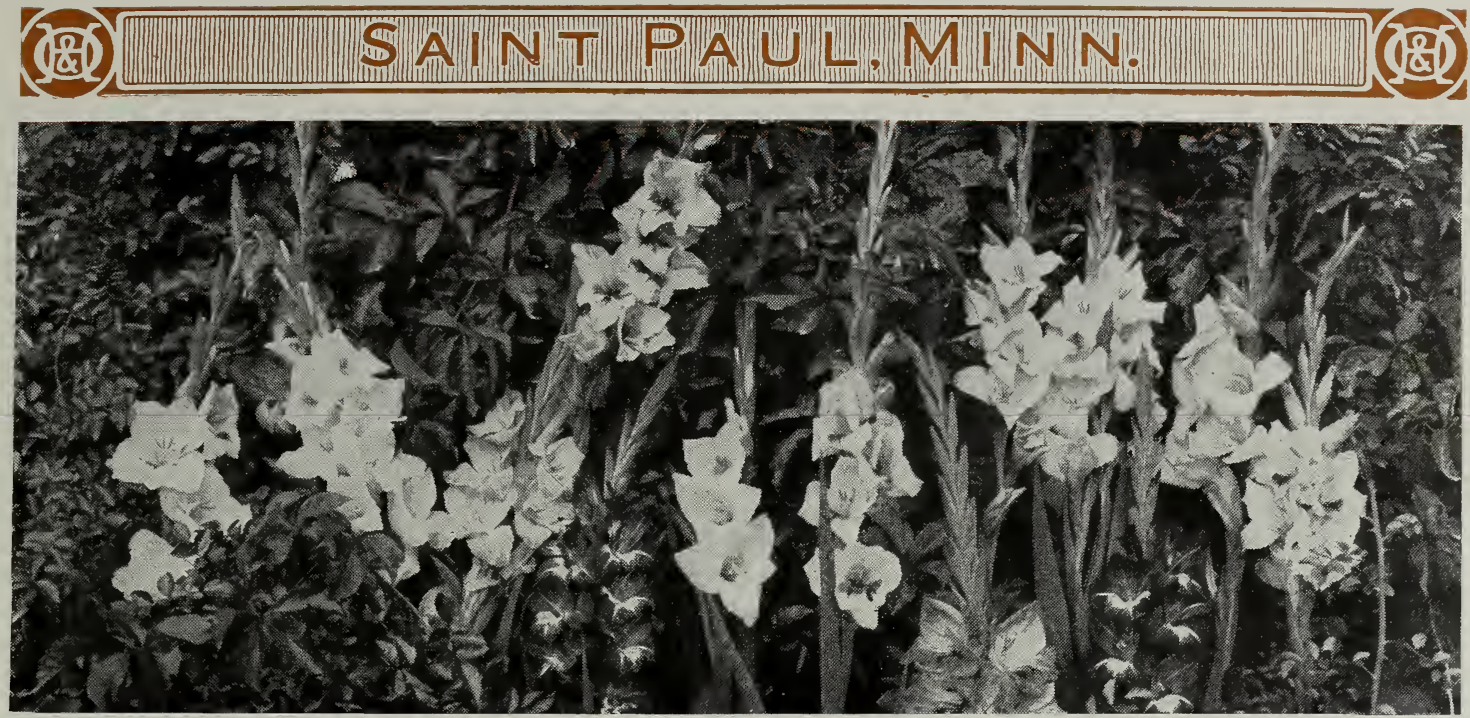

Gladioli are flowers for real companions-day after day you enjoy their unfolding petals and dainty colors

\section{QUALITY GLADIOLI}

$\mathrm{U}$

SE a sandy loam, but if this is not to be had, use soil that is well drained. The soil should be well fertilized with stable manure, plowing or spading the earth in the fall and scattering the manure; in the spring, work the fertilizer into the soil. Other fertilizers are good, but we prefer manure. Planting should be done from May 1 to June 1, making plantings from ten days to two weeks apart, extending the blooming season. Large bulbs should be planted about 6 inches deep, the smaller sizes from 3 to 4 inches deep. We are large growers of Gladioli, and have the best selections to be had, using Iarge quantities of the cut blooms for our select flower trade.

\section{NEW AND RARE SORTS}

America. Flesh-pink. Flowers immense, borne on strong spike. 40 cts. per doz., $\$ 2.50$ per 100 .

Attraction. Deep rose, with white throat. $75 \mathrm{cts}$. per doz., \$5 per 100 .

Augusta. White with Iavender anthers. Strong spike. 40 cts. per doz., $\$ 2.50$ per 100 .

Baron Hulot. A deep violet-blue with well-opened flowers. 75 cts. per doz., $\$ 5$ per 100.

Dawn. Beautiful shell-pink. 25 cts. each, $\$ 2.50$ per doz.

Electra. Orange-red. Flowers large and spike tall. 15 cts. each, $\$ 1.50$ per doz.

Europa. Pure snow-white, large spikes. Considered the best white. $30 \mathrm{cts}$. each, $\$ 3$ per doz.

Empress of India. A rich dark red, rare and beautiful. One of the best. 30 cts. each, $\$ 3$ per doz.

Glory of Holland. A new white with slight tinting of pale pink and anthers of delicate lavender. 20 cts. each, $\$ 2$ per doz.

Halley. Early-blooming. Large well-opened flowers of delicate salmon-pink. 75 c. per doz., $\$ 5$ per 100 .

Klondyke. Clear primrose-yellow with crimson blotch. 75 cts. per doz., $\$ 5$ per 100.

Liebesfeuer. A new red of Brenchleyensis type, but much larger flower, with soft salmon blotch in throat. 50 cts. each, \$5 per doz.

Lily Lehman. No white Gladiolus equals this variety. A pure glistening white, with just a tint of pink on tips of petals. $15 \mathrm{c}$. each, $\$ 1.25$ per doz.

Minnesota. Fine salmon-pink, large blossom; early. 10 cts. each, \$1 per doz.

Mrs. Frances King. (The original.) Beautiful "Besnard Shade" flame-pink. Immense flowers on spike 4 feet high. 40 cts. per doz., $\$ 2.50$ per 100 .

Niagara. Light crocus-yellow, throat shaded deeper. Large open flowers on a strong spike. For color, texture, and keeping-qualities this is one of the best. 15 cts. each, $\$ 1.25$ per doz.
Panama. Has created a sensation on account of its large wide-open wax-like flowers of glowing mauve-rose. 15 cts. each, $\$ 1.50$ per doz.

Peace. Large white flowers; pale violet feathering on lower petals. 15 cts. each; $\$ 1.50$ per doz.

Princeps. (The Thousand-Dollar Gladiolus.) Amaryllis-like flowers of a rich dark scarlet marked white on lower petals. $\$ 1$ per doz., $\$ 6$ per 100 .

Queen of the Yellows. Large clear yellow. The best of its color. $20 \mathrm{cts}$. each, $\$ 2$ per doz.

Willy Wigman. Large, wide open flower. Bloom of a beautiful blush tint, with long bright tulip blotch on lower petals. $15 \mathrm{cts}$. each, $\$ 1.50$ per doz.

\section{GOLD MEDAL MIXTURES}

These mixtures contain good varieties as well as new hybrids. 50 cts. per doz., \$4 per 100.

Gold Medal Mixture No. 1. Shades of scarlet, blood-red, and amaranth.

Gold Medal Mixture No. 2. Shades of pink, delicate to rose.

Gold Medal Mixture No. 3. Contains the shades of Nos. 1 and 2, also blue and lilac shades.

\section{EXTRA-SPECIAL COLLECTION}

Twelve varieties of recent introduction and great merit. Some have never been offered before and, if bought separately, would cost $\$ 3$. Our price for this collection of twelve varieties, $\$ 1$ per doz.

\section{RAINBOW COLLECTION}

For those who do not care for rare varieties. This collection contains of every color and shade in Gladioli, and, if bought separately, would cost at least $\$ 1$. Our price, 60 cts. per doz.

Club Mixture. Contains good varieties of all colors. Will give general satisfaction. 35 cts. per doz., \$2 per 100 . 


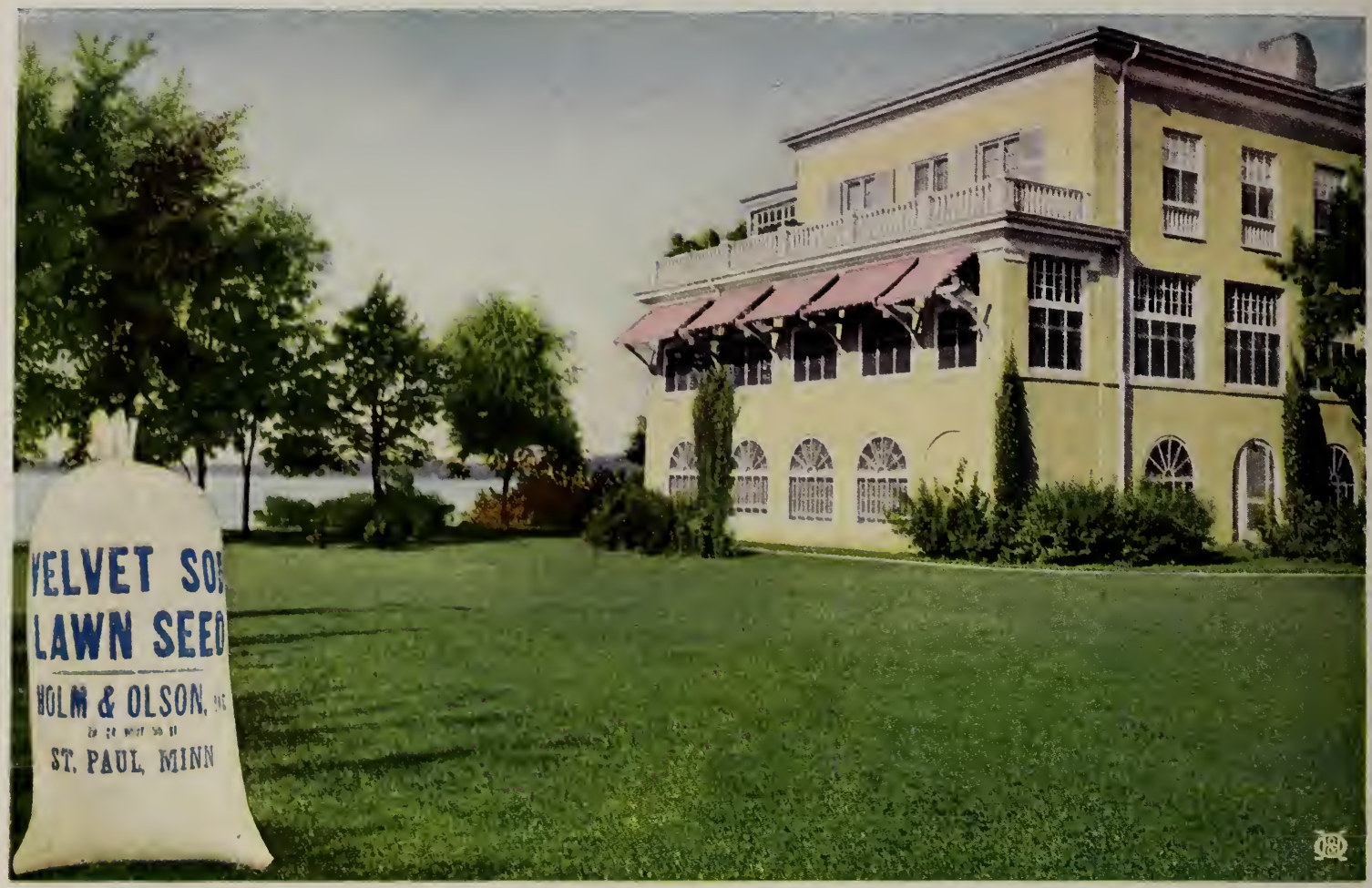

Tbis splendid lawn was made by the H. o O. Service-engineering, grading, and seeding with Velvet-Sod mixture

\section{VELVET-SOD LAWN SEED}

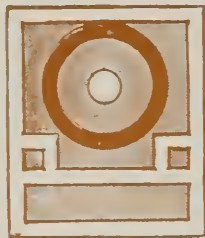

NE of the most essential parts of the country place and suburban home is a properly made and well-kept lawn. We have made careful study of the grasses required for best results, and the formulas of our various grass mixtures are based upon these experiments.

The days of laboriously making Iawns from sod are rapidly passing away. Good Iawns are now made from good grass seed - the essentials are a careful blending of varieties adapted to producing a thick turf with velvety appearance. Each variety in this composition has a special purpose; some make strong, frbrous roots, that take hold on the earth and hold it in position; others, of a creeping nature, quickly fill up the vacant spots; yet other sorts are used for their color value, besides kinds that are able to withstand heavy or excessive rains. Our Velvet-Sod Mixture is composed of the best, strictly pure seeds of hardy lawn grasses from America and Europe. It quickly produces a permanent lawn of rich green and Iuxuriant growth. If you need grass seed for only a small city yard, or a large lawn of acres, use this mixture.

The preparation of soil must be thorough before seeding. Either plow or spade so that every foot of earth is stirred; then smooth until a perfect grade is secured and the soil well pulverized. If not rich, it should be fertilized in advance of seeding. Work the fertilizer thoroughly into the soil, so it will not require additional enriching for several years.

Seeding should be done when the wind is quiet-usually in the early morning. Select a day, if possible, just before a rain, if water is not at hand. A good plan is to cross-seed, so that no spots will be missed. After sowing, rake the seed into the soil lightly, and roll evenly.

QUANTITY OF SEED TO SOW.- One pound of our lawn grass seed will sow $10 \times 20$ feet, or 200 square feet. This is heavier than recommended by many seedsmen, but practical experience in making lawns in our landscape department has taught us to use sufficient seed, and the best that can be obtained.

\section{VELVET-SOD MIXTURE}

Our Velvet-Sod Mixture will make a close, thick turf in a very few weeks. The seed roots deeply, enabling the lawn to withstand severe drought, and maintaining its beautiful, rich green the entire season. This mixture is no doubt the cheapest lawn seed offered, not on account of the price, but more on the point of high quality and quantity of actual seed to the bushel, which contains twenty pounds of the best kinds and varieties of grasses used for Iawn purposes. We know our mixture to be among the best on the market, and we ask our patrons to carefully consider this before placing their order. The weight of this mixture shows its extra-high quality, and it is entirely free from chaff of every kind. Our practical experience as landscape gardeners has taught us the best Lawn Grass Mixture for parks, cemeteries and private grounds. Lb. 30 cts., 5 lbs. $\$ 1.50,10$ Ibs. $\$ 2.75$, bus. (20 Ibs.) $\$ 5$.

\section{CAPITAL CITY MIXTURE}

This mixture is admirably adapted to all uses, but the quality of the seed is not so high as our VelvetSod Mixture; but, for ordinary sowing, will answer the same purpose and we know it is equal to any other mixture on the market. It will make a close, beautiful sward in a short time. Lb. 25 cts., 5 lbs. $\$ 1.25,10$ Ibs. $\$ 2.25$, bus. (20 Ibs.) \$4. 

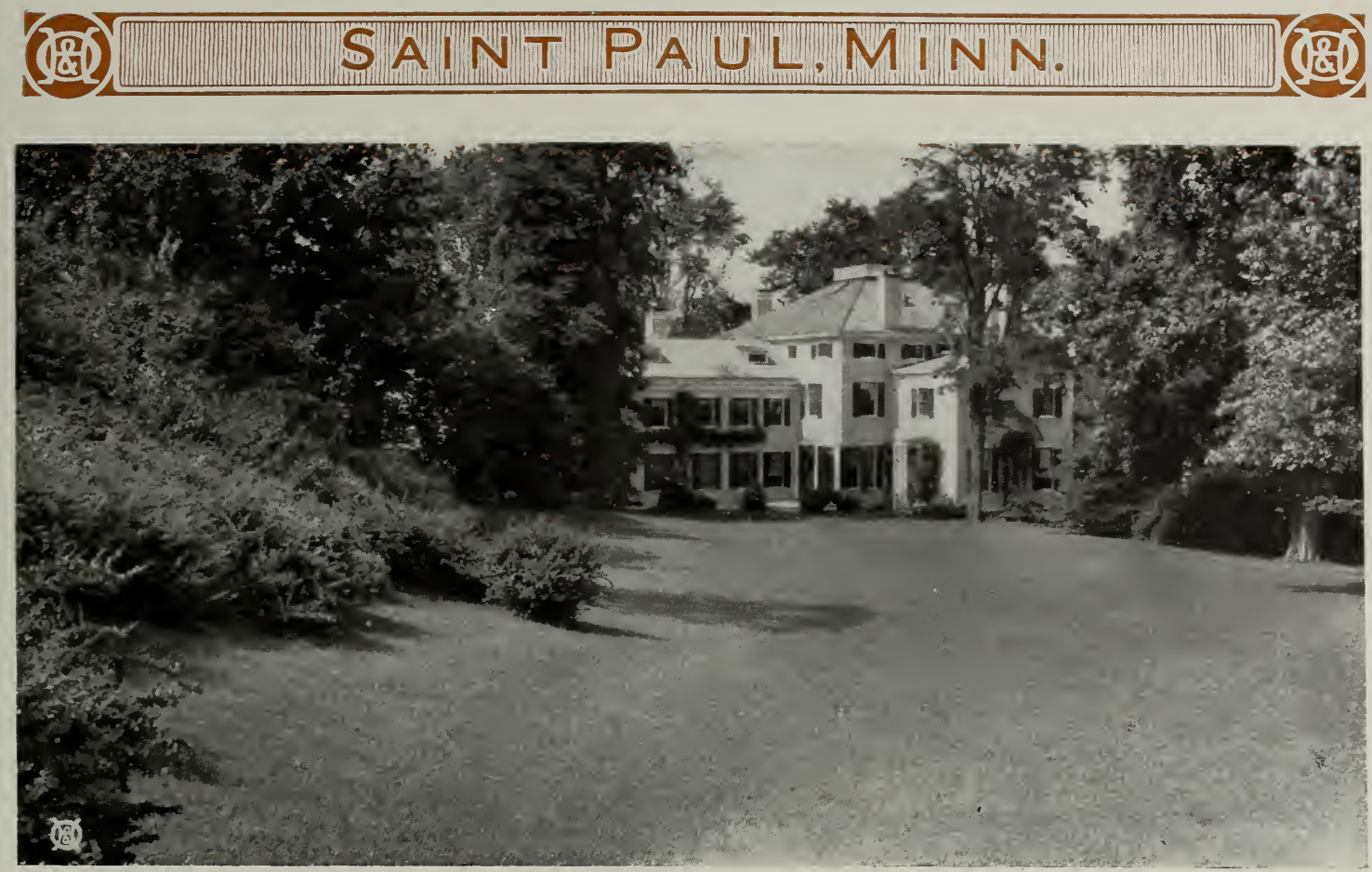

Our Special Lawn Fertilizer produces a permanent lawn of rich, luxuriant green

\section{SHADY-SIDE MIXTURE}

Usually it is quite diffrcult to obtain a satisfactory growth of grass under trees and in shady places; for sowing in such places, we recommend the use of this Shady-Side Mixture. It will produce quickly an abundant and even growth of beautiful green grass. The grasses used in making this special mixture are only those that are well adapted to growing in the shade. Lb. 35 cts., 5 Ibs. $\$ 1.75$, 10 Ibs. $\$ 3.25$, bus. (20 Ibs.) \$6.

\section{GOLF-LINK MIXTURE}

This mixture is composed of grasses best suited for golf-links, and is the result of careful experiments, as weIl as careful watching for several years of practical results on golf-links sown with our grass seeds. By the use of this mixture, and with proper care and attention, the finest links can be rivaled. Lb. 30c., 5 Ibs. $\$ 1.50,10$ Ibs. $\$ 2.75$, bus. (20 Ibs.) \$5.

\section{PUTTING-GREEN MIXTURE}

The hardiest and finest low-growing grasses are contained in this mixture. It produces a beautiful and lasting turf calculated to withstand hard wear. Lb. 50 cts., 5 Ibs. \$2, 10 Ibs. \$3.75, bus. (20 Ibs.) \$7.

\section{TERRACE MIXTURE}

A special mixture of grasses for sowing on terraces and hillsides, producing spreading roots, thus preventing heavy rains from washing out. It will withstand drought and exposure, and thrive on shallow soils, and at the same time produce a rich green lawn throughout the season. Lb. 30 cts., 5 Ibs. $\$ 1.50,10$ Ibs. $\$ 2.75$, bus. (20 Ibs.) \$5.

\section{WHITE CLOVER}

The best variety for lawns, as it forms a close herbage and remains green throughout the season. It is also valuable when mixed with grass seed for pasture. Sow in spring at the rate of six pounds to the acre when sown alone; half the quantity when sown with other grasses. 1/2 Ib. 35 cts., Ib. 60 cts., 5 Ibs. $\$ 2.75$.

\section{KENTUCKY BLUE GRASS}

This is rated as the finest permanent pasture grass. Especially suited to meadows and rich lands. It is the grass of the famous and fertile limestone soils of Kentucky, and is no less a favorite all through the northern states. A perfect lawn grass. Lb. 25 c., 5 Ibs. $\$ 1.25,10$ Ibs. $\$ 2.25$, bus. (20 Ibs.) \$4.

\section{SPECIAL LAWN FERTILIZER}

If the lawn is in fair condition, rake off the dead grass and leaves in the early spring, and scatter broadcast over the surface, then wet it down thoroughly so that the strength is carried to the roots of the grass. The first application should be made early in spring, as soon as frost is out of the ground, at the rate of 25 Ibs. to 1,000 square feet. 5 Ibs. 30 cts., 10 Ibs. 50 cts., 25 Ibs. \$1, 100 Ibs. \$3, 200 Ibs. \$5.50, 500 Ibs. \$12.

Bone Meal. One of the best fertilizers known. As a Iawn dressing it is unsurpassed. Should be applied at the rate of one pound to fifty square feet of lawn. Very lasting in its effect. 5 Ibs. 25 cts., 50 Ibs. \$1.75, 100 Ibs. \$3.

Nitrate of Soda. Not a substitute for other manures, but we recommend it as the cheapest and best form in which to apply nitrogen to plants, producing a very quick growth. 5 Ibs. 50c., 25 Ibs. \$2.50, 100 Ibs. \$8.

Hard-wood Ashes. One of the best lawn fertilizers; contains Iarge amount of potash. Apply in the Iate faIl or early spring, 1,000 to 1,500 pounds to the acre. 5 Ibs. 25 cts., 25 Ibs. $\$ 1,100$ Ibs. $\$ 2.50$.

SHEEP MANURE, Pulverized. A pure natural manure, excellent for lawn or garden. Apply in fall or spring. Also excellent for potting. 5 lbs. 25 cts., 25 Ibs. \$1, 100 Ibs. \$2, 1,000 Ibs. \$16.

Plant Food. H. \& O. Brand especially prepared for house-plants and the home garden. Odorless and sanitary. Box 25 cts. 


\section{TOOLS FOR LAWN AND GARDEN}

Our Iong experience has convinced us that the quality and practicability of the Lawn and Garden Tools we recommend are the essentials of making gardening a pleasure. Our stock contains tools and equipment of all descriptions that simplify the work of the garden. As to quality, we have only the best. We select only the highest grades of the various tools, which makes our assortment complete and the standard of quality the best.

\section{PHILADELPHIA LAWN TRIMMER}

The Philadelphia Lawn Trimmer has all the excellent qualities of the Philadelphia Lawn Mower. It has but one drive wheel, and is specially adapted for mowing close to the edge of sidewalks and fences, around trees or in corners where it is impossible to reach with a mower. \$6.50 each.

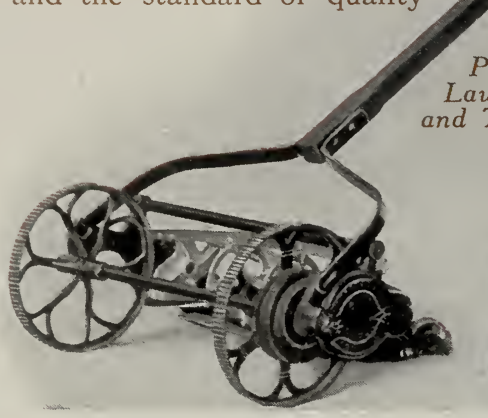

Pbiladelpbic Lawn Mower Trimmer

\section{HANDY LAWN TRIMMER}

Operates on the lawn-mower principle; equipped with gearing which runs knives when the machine is in motion. Trims close to the edges of walks, flower-beds, fences, etc. \$3 each.

\section{GENUINE PHILADELPHIA LAWN MOWERS}

We recommend them as the best Mowers made. Style A, High Wheel. Constructed of fine steel throughout. The mechanism is so arranged as to make it very easy-running. Has 10-inch drive wheels, cylinder has four blades; diameter of cylinder $61 / 2$ inches; train of three gears and double ratchet, making both wheels drivers. For durability it is unsurpassed.

\begin{tabular}{|c|c|c|c|}
\hline $\begin{array}{ll}\text { No. } \\
\text { A } & 15 . \\
\text { A } & 17 \\
\text { A } & 19 \\
\text { A } & 21\end{array}$ & $\begin{array}{l}\text { Width of cut } \\
\ldots 15 \text { in. } . \\
\ldots 17 \text { in. } \\
\ldots 19 \text { in. } . \\
21 \text { in. } .\end{array}$ & $\begin{array}{l}\text { Weight } \\
70 \text { Ibs.. } \\
72 \text { Ibs.. } \\
74 \text { Ibs.. } \\
78 \text { Ibs.. }\end{array}$ & $\begin{aligned} & \text { Each } \\
& . \$ 1500 \\
& . \quad 1650 \\
& 1800 \\
& .2000\end{aligned}$ \\
\hline
\end{tabular}

Style K, High Wheel. Unexcelled for fine work and well made. Has 10 -inch drive wheels, five blades, 61/2-inch cylinder; geared on both sides, single pinion; light-running and cuts smoothly. Its principles of construction are so evenly balanced as to make it very durable.

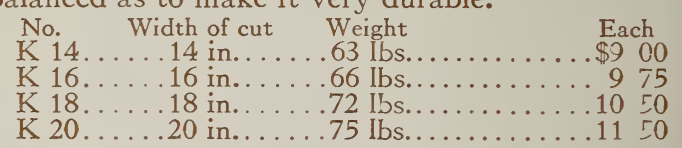

Style E, High Wheel. The best Mower, made of iron and steel. Has 10-inch drive wheels, four blades, $61 / 2$-inch cylinder, train of three gears, double ratchet, making both wheels drivers. Has a solid frame. The cylinder box caps can be taken off and cylinder removed without disturbing the frame of the mower.

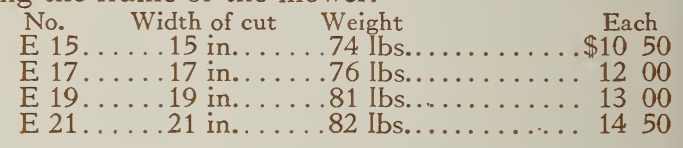

\section{EAGLE PHILADELPHIA HORSE MOWER}

Made with added weight of iron for strength, increased diameter of cylinder for draft, and large shafting and journals for durability. Has patent adjustable boxes for taking up the wear of journals, wrought-iron front and back girths, making the frame solid; cutting cylinder is stationary; bed knife is adjustable to cylinder; blades are riveted to the spiders. Five

cylinder blades; height of driving roller 14 inches; diameter of cylinder $71 / 2$ inches.

Equipped with seat, shafts and side-draft attachment. No reduction is made without seat and shafts.

This machine is not carried in stock but has to
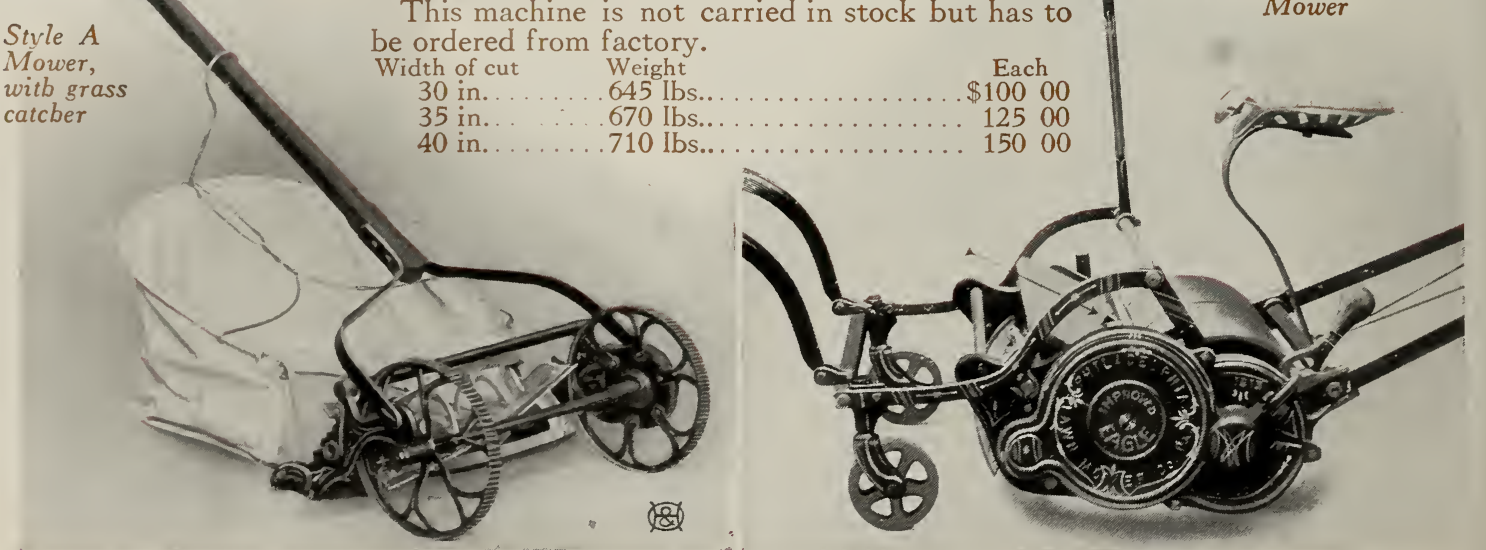


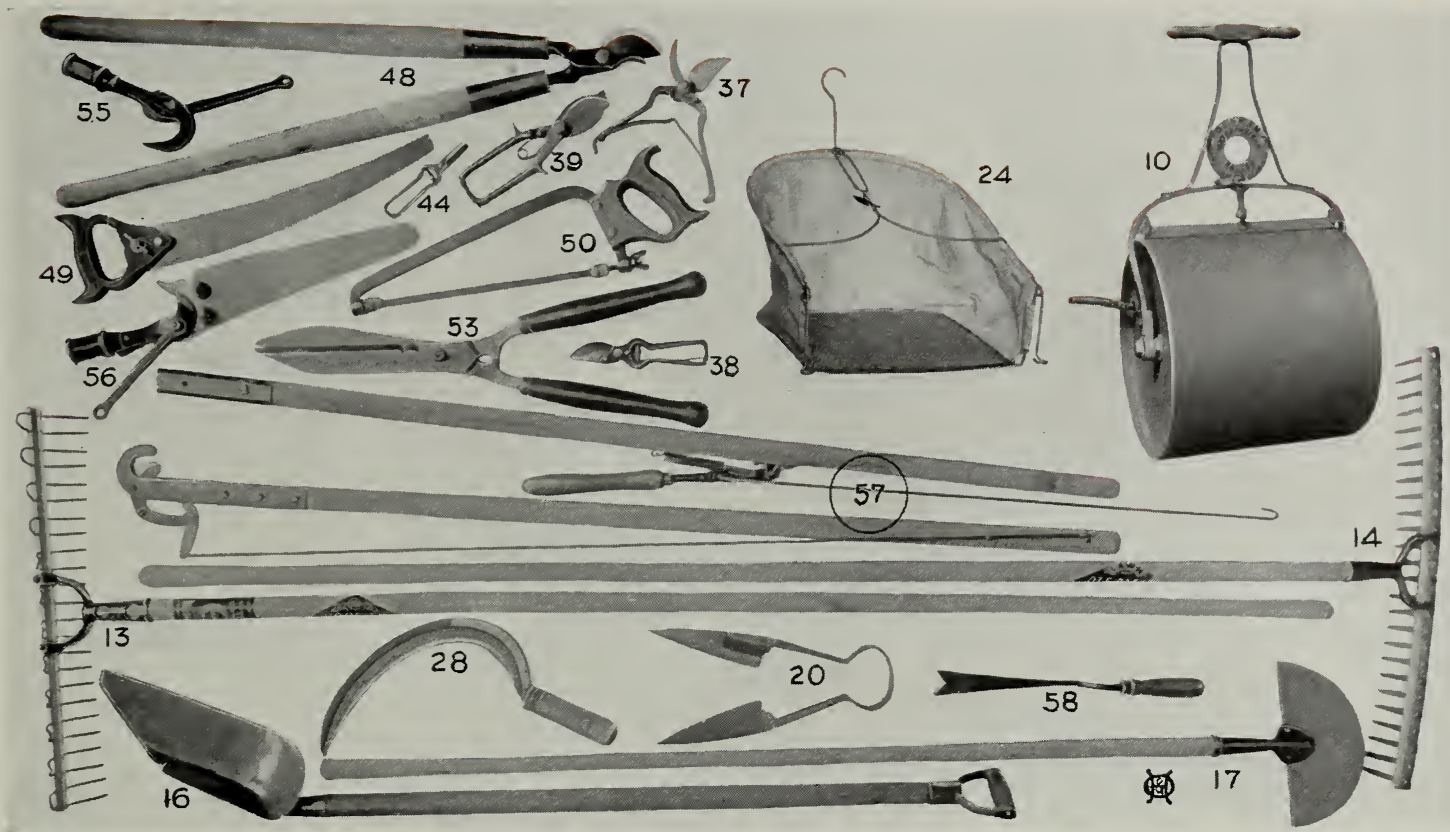

A well-kept lawn is the wish of every one. Practical tools make the work a pleasure

\section{LAWN ROLLERS}

The rolling of your lawn is essential in promoting an even growth of grass and in eradicating noxious weeds. Moreover, it is beneficial to the life of the grass.

No. 10, Water-weighted Lawn Rollers. These Rollers are weighted with water to the desired weight. With the aid of the roller bearings, an easy running Roller is had. Equipped with combination handle, lock, and scraper.

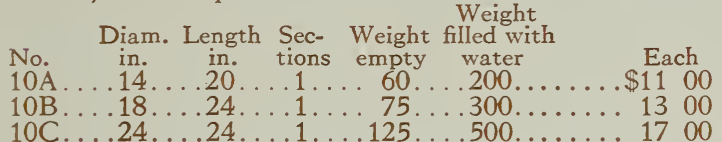

\section{LAWN RAKES}

No. 13, Wire. Has 24 teeth, tinned metal heads, and sockets; reversible. 55 cts. each.

No. 14, Wooden. The "Ole Olson" has 26 hickory teeth. 75 cts. each.

\section{LAWN-EDGE TRIMMERS}

No. 16, Imperial Edger. The most perfect implement for edging a lawn, making the trench or edge of the lawn uniform. Easy to operate and well made. $90 \mathrm{cts}$. each.

No. 17, Turf Edger. Steel blade; solid shank. For edging flower-beds, shrubbery, and around trees. 75 cts. each.

\section{GRASS SHEARS}

No. 20 A. Fine steel, polished. Blade 6 inches.. $\$ 100$ No. 20 B. Hardened and tempered steel. Blade 6 inches.

No. 20 C. Blade $51 / 2$ inches

No. 20 D. Midget Blade. 4 inches........ 50

\section{GRASS CATCHERS}

Easy emptying; heavy duck sides; galvanized-steel bottom, frame, and hook. Can be attached or detached instantly. Projecticns on bottom prevent grass from slipping.

Each

No. 24-G 10. Adjustable to 12 - to 18 -inch mower. $\$ 140$

No. 24-G 12. Adjustable to 18- to 22-inch mower. 165

No. 28. Grass Hooks. Superior-quality steel blade, well made..

\section{PRUNING SHEARS}

Heavy nickel, double brass spring, full polished:

No. 37. $81 / 2$ inches.

Each

Full-polished nickel, coil spring:

No. 37 A. 8 inches

No. 37 B. 7 inches.

No. 37 C. 6 inches

Black handles, coil spring, polished blade:

No. 38 A. 8 inches

No. 38 B. 7 inches.

No. 39, Rhodes Double-jawed Shears. Both edges are cutting edges.

No. 44, Ladies' Flower-gathering Shears. Full nickel.

No. 47, Grape or Flower-cutting Shears. Black

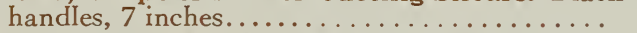

No. 48, Two-Hand Pruner. Extra heavy; handle 20 inches..................................

No. 49, Pruning Saw. Double cutting edges; ad- 100

No. 50, Pruning Saw. Swivel blade; heavy frame. 150 Extra blades....................... 25

\section{GARDEN or HEDGE SHEARS}

Solid steel, hand-forged. Each No. 53 A. Swedish steel. 9-inch notched blade.. \$3 00 No. 53 B. American steel. 9-inch notched blade. 200 No. 53 C. Ladies' size. 51/2-inch blade... . . . . 150

\section{TREE-TRIMMERS}

No. 55, Disston's Little Giant Tree Pruner. Especially adapted for cutting tall branches. .

No. 56, With saw attachment. For large branches..

No. 57, Bartlett Sectional Tree-Trimmer. Reinforced double action on jaws, which makes it easy to operate and adds strength in cutting. 4 -feet sections. Two sections make a trimmer, or any number over two can be used. The best all-round Tree-Trimmer. 12 feet long, three sections.

No. 58, Asparagus Knife, or Dandelion Digger. Forged steel.. . 涪 


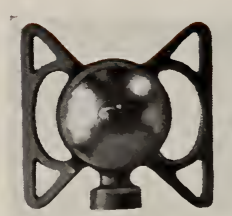

$73 \mathrm{~A}$
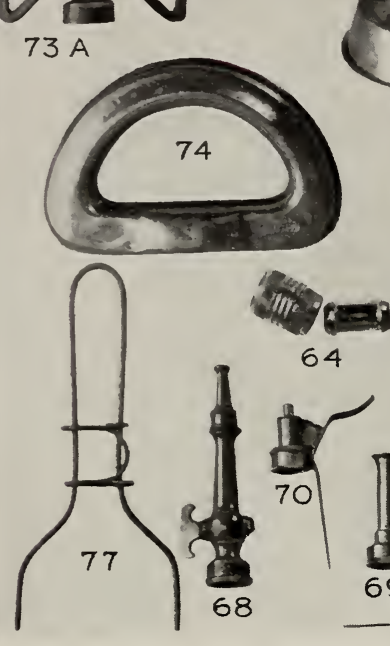

64
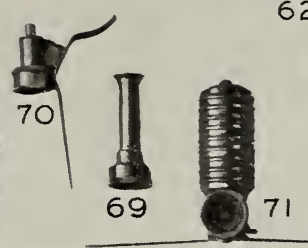

\section{GARDEN HOSE}

No. 60, Electric. The best non-kinkable. 3/4-inch. A Hose that is absolutely in a class by itself for durability. AII lengths with clincher couplings. 100 feet with couplings. 50 feet with couplings.
25 feet with couplings.

Kineo. A good grade of Hose for all uses. $3 / 4$-inch. 100 feet with couplings.

50 feet with couplings.

We furnish other qualities of $3 / 4$-inch and $1 / 2$-inch Hose and shall be pleased to quote prices.

\section{HOSE ACCESSORIES}

No. 62, Perfect Clincher Couplings. AII brass; will not puIl off. $3 / 4$-inch. 25 cts. per set.

No. 63, Perfect Clincher Mender. Easily and quickly adjusted. Brass tube and galvanized clamps. $3 / 4$-inch. 10 cts. each, $\$ 1$ per doz.

No. 64, Sure-on Mender. A brass mender that perfectly mends the hose. $15 \mathrm{cts}$. each.

DETACHABLE HOSE REEL, No. 65 A. The handiest and most compact outfit of its kind. The hose is quickly rolled up; loosen the thumb-screw and slip the reel off the faucet. Attached and detached instantly. \$5 each.

No. 65 B, Extra Faucet. $\$ 1.50$ each.

ALL-STEEL HOSE REEL, No. 66. Strongly constructed; easy to push about. \$3 each.

No. 67, Speco Hose Reel. Especially designed for use on large lawns. It will easily carry 200 feet of $3 / 4$-inch hose. Any desired length of hose may be pulled off. $\$ 10$ each.

\section{HOSE NOZZLES}

No. 68, Magic Nozzle. AII brass; with shut-off. 85 cts. each.

No. 69, Universal Nozzle. A simple brass nozzle that gives results. $40 \mathrm{cts}$. each.

No. 70, Central Nozzle. Two-in-one nozzle and sprinkler. $30 \mathrm{cts}$. each.

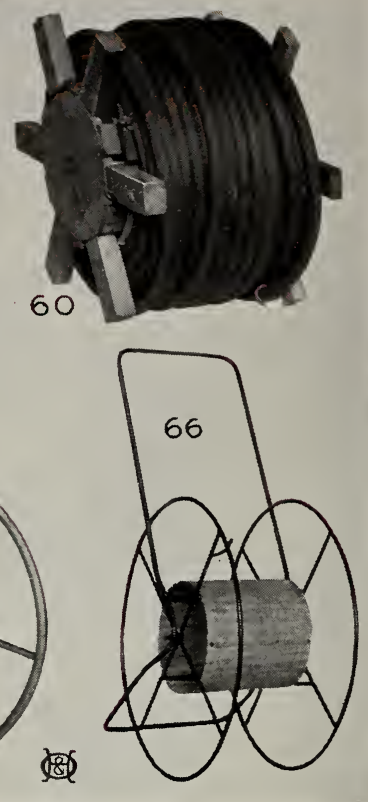

\section{LAWN SPRINKLERS}

Something new in the way of a Lawn Sprinkler.

\section{THE FIN DE SIECLE B}

This Sprinkler is not set in the center of the Iawn you wish to sprinkle, but on the side; therefore you avoid having to wet your feet in changing its location. It also prevents watering the sidewalk, and perhaps the street, and incidentally saves water, as it sprinkles only the desired lawn.

No. 71 BD. Will cover an oblong space, 10 by 40 feet. $\$ 2$ each.

No. 71 BF. Will cover a square space of 22 by 22 feet, which places the sprinkler at one corner of the square. \$2 each.

No. 71 BJ. Will cover an oblong space of 800 square feet, or 20 by 40 feet. $\$ 2$ each.

These Sprinklers are constructed of brass, and have been thoroughly tested. They will solve your sprinkling troubles.

THREE-ARM WHIRLER, No. 72. Standard size arms, nickel-plated, black enamel base. $\$ 2$ each.

LITTLE WONDER, No. 73 A. On base; throws a fine spray. 75 cts. each.

LITTLE WONDER, No. 73 B. With spike to stick in ground. 65 cts. each.

CRESCENT FOUNTAIN, No. 74. Sprinkles to a straight line. No need of turning off water to change its position. Finished in brass; galvanized bottom. 85 cts. each.

FOUNTAIN, No. 75. Sprinkles a square area; finished in brass; galvanized bottom. 85 cts. each.

HANDY, No. 76. The best little sprinkler. $50 \mathrm{cts}$ each.

HANDY HOSE-HOLDER, No. 77. Galvanized iron. 15 cts. each.

All of the Garden supplies listed in this catalogue are manufactured by well-known and reliable houses. Their guarantee and our own reputation are back of every article here offered. 

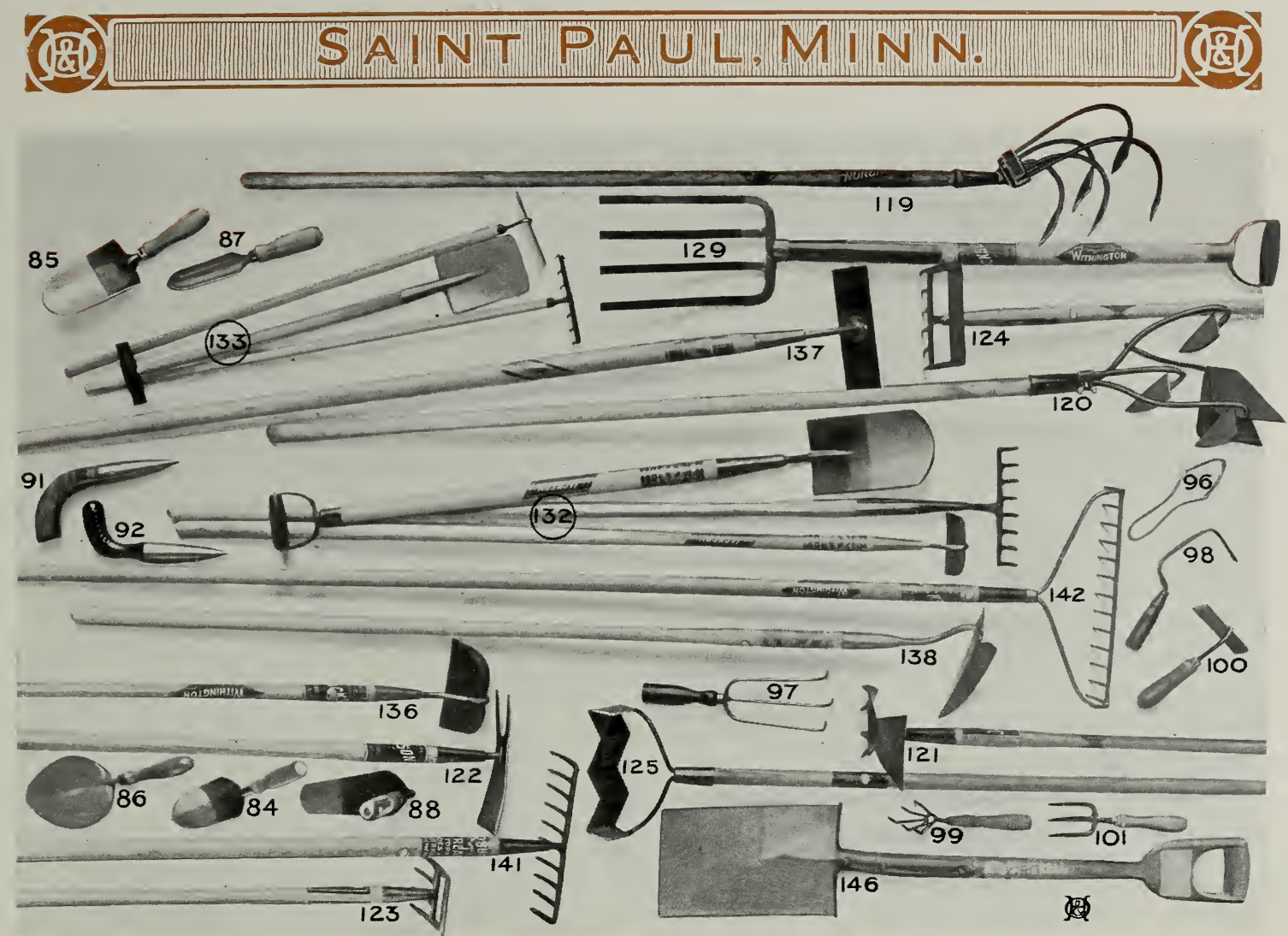

Quality Garden Tools. Only the best. Adapted to all uses. Also especially light and well-made tools for ladies' use

\section{GARDEN TROWELS}

Forged Steel Blade and Shank, extra-frne quality.

No. 84 A. $4 \frac{1}{2}$ inches.

No. 84 B. 5 inches.

No. 84 C. 6 inches.

No. 84 D. 7 inches.

Steel Riveted Shank.

No. 85. 6 inches....

Special Bulb Trowel, almost circular.

No. 86. 6 inches. .

Transplanting. Trowel, narrow blade.

No. 87 A. 5 inches.

No. 87 B. 6 inches

No. 87 C. 7 inches.

No. 87 D. 8 inches.

Transplanting Hoe-Trowel, for tomato plants,

No. 88.7 inches....

\section{DIBBLES}

For transplanting small plants and bulbs.

No. 91. Wood-Handle Iron Dibble.

No. 92. All-Iron Dibble..

\section{HAND WEEDERS}

No. 96, Christy. Cast-steel

No. 97, Eureka. Prongs hand-forged steel.. .

No. 98, Hazeltine. Hand. Cast-steel.... .

No. 99, Excelsior. Weeding Hook, 5 fingers

No. 100, Beet Weeders. Cast-steel, 41/2-inch blade...

No. 101, Strawberry Fork. Malleable, 3 prongs.

No. 119, Norcross Hand Cultivator. The prongs are spring steel, the shovels are forged from steel prongs.

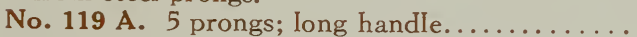

No. 119 B. 3 prongs; Iong handle.

No. 119 C. 3 prongs; short handle.
$\$ 0$ Each

\section{HAND WEEDERS, continued}

No. 120, Cultivator, Hand, Gardener's Friend. One of the most convenient and economical tools in the market. $\$ 1$ each.

\section{WEEDERS, LONG-HANDLED}

Each

No. 121, Acme. Two-prong, steel blades...... .\$0 80

No. 122. Two-prong, sheet-steel blades........ 30

No. 123. Four-prong Hoe and Rake Weeder.... 60

No. 124. Six-prong Hoe and Rake Weeder.... 70

No. 125. Rapid-Easy Weeder, shovel steel, zigzag edges................... 80

No. 129, Forks, Spading. Solid steel shank, angular tines.

A, 4 tines, light................ 85

$\mathrm{B}, 4$ tines, heavy ................. 90

C, 5 tines, heavy.................. 125

No. 132. Garden Tools, special set for Iadies' usc.

Hoe, rake and spade, well made.......... 100

No. 133. Child's set of hoe, rake and spade.... 35

Hoes. Cast-steeI Shank. 4-foot handle.

No. 136 A. 6-inch blade............... 55

No. 136 B. 5 -inch blade................. 50

No. 136 C. 4-inch blade................. 45

No. 137, Hoe, Scuffle. Single shank, steel blade riveted to malleable-iron shank. $21 / 2$ by 8 -inch bade, 5-ft. handle. .

No. 138, Hoe, Warren Field. 71/2-inch blade,

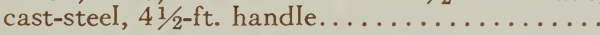

No. 141, Garden Rake. High-grade steel; 3-inch straight teeth; 6-foot handle.

10 teeth 12 teeth

No. 142, Rake, Solid Bow. Entire rake a solid piece of forged steel; 13 teeth

No. 146, Spade. Solid cast-steel, 71/4 by 12 inches...

We are professional gardeners. Our experience enables us to select practical tools 


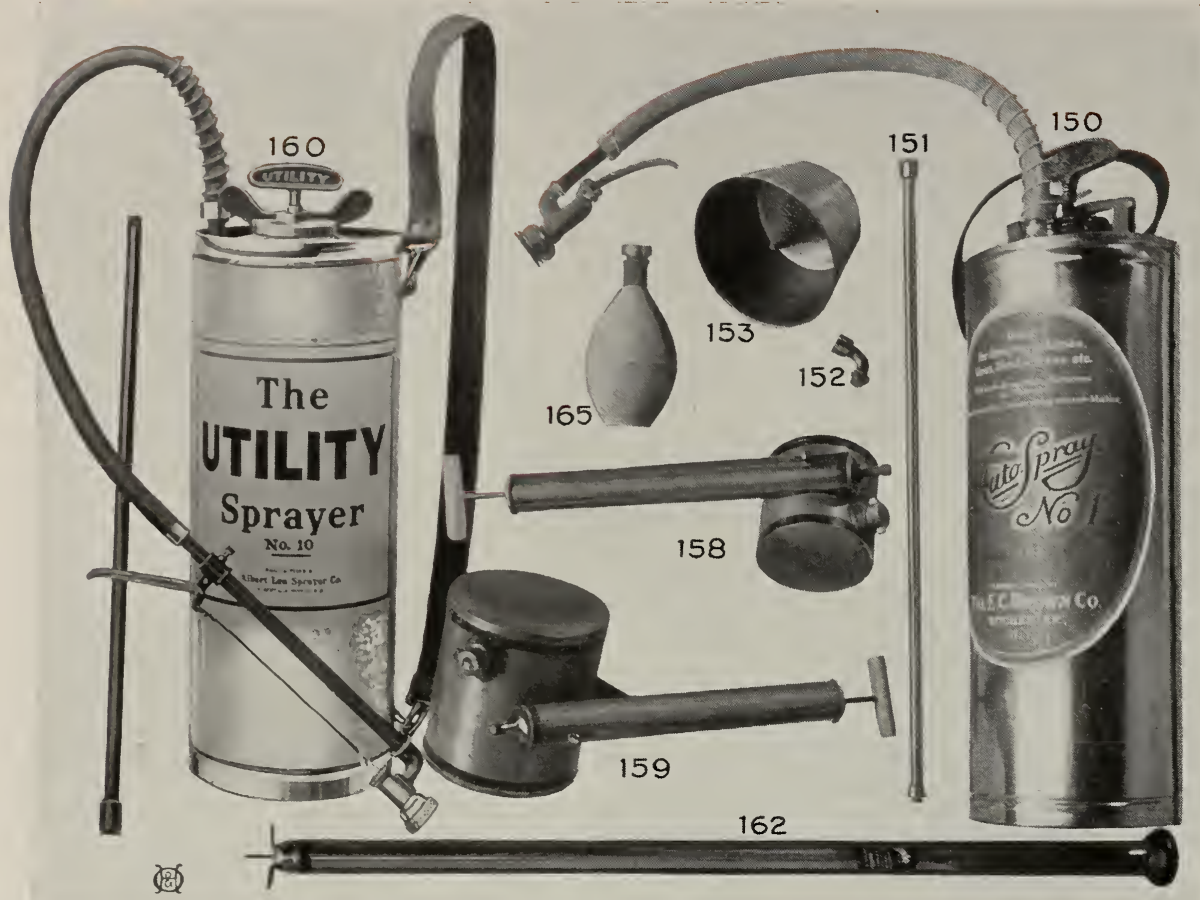

\section{SPRAYING}

The insect pests are constantly increasing. Hence, it is essential for the home-gardener to be prepared for spraying. "An ounce of prevention is worth a pound of cure." Spraying should be done early in the season and continued throughout the summer. Our Sprayers have been considered from a practical standpoint, and our list of insecticides has been carefully selected. A spraying. chart will be sent on application. By its use you will know when to spray and what to use.

\section{SPRAYERS}

No. 150, Auto-Spray No. 1. The strongest and most simple compressed-air Spraver. Equipped with carrying strap, 2 feet of $1 / 2$-inch hose, fine-spray nozzle, solid-stream cap, and the auto-pop, which, by operating the lever in the hand, opens and closes the valve, thus directing the spray. The only selfcleaning nozzle. Heavy brass tank. $\$ 8.50$ each.

Auto-Spray No. 1 Attachments:

No. 151, Extension Rods. Solid Brass, 2-foot length. $60 \mathrm{cts}$. each.

No. 152, Elbow Extension. Solid Brass. 30c. each. No. 153, Strainer. Solid Brass. \$1 each.

No. 158, Auto-Spray. Practical small Sprayer. Will handle all solutions. Can be easily cleaned.

No. 158 A. 1 quart; all tin. 80 cts. each.

No. 158 B. 1 quart; galvanized tank. 90 cts. each.

No. 158 C. 1 quart; brass tank. \$1.25 each.

No. 159 A. 2 quart; galvanized tank. $\$ 1.20$ each.

No. 159 B. 2 quart; brass tank. $\$ 1.75$ each.

No. 160, The Utility Sprayer is an extra-high pressure Sprayer. Capacity of tank $31 / 2$ gallons. Equipped with standard hose connections. Made of heavy galvanized iron. \$6 each.

No. 162, Erado. Through the perfection of the Erado the old-fashioned laborious and back-breakin method of digging up dandelions is eliminated. The plunger is forced into the heart of the dandelion and by a twist of the wrist the knives cut of the top and sufficient liquid is allowed to drop on the root to destroy it. When filled with Knoxweed, dandelions, burdock, etc., are easily destroyed.

No. 162 A. Galvanized-iron cylinder; brass tip; iron handle. \$1 each.

No. 162 B. Painted steel cylinder; brass tip; iron handle. \$1 each.

No. 162 C. Brass-covered cylinder; brass tip; iron handle. \$1 each.

No. 162 D. Solid brass, with iron handle. $\$ 1.50$ each.

No. 165, Rubber Plant Sprinklers. A handy Sprinkler for use on your house plants.

No. 165 A. Small size, $90 \mathrm{cts}$. each.

No. 165 B. Medium size. \$1.25 each.

No. 165 C. Large size. $\$ 1.50$ each.
INSECTICIDES AND FUNGICIDES

Arsenate of Lead (Paste). Will destroy all leaf-eating insects. Will not wash off or in any way burn the foliage. 1 -lb. can, 30 cts.

Bordeaux Mixture (Dry). For mildew, blight, and fungous diseases. 1-lb. can, 25 cts.

Bordeaux Mixture (Paste). Use 1 pint to 6 gallons of water. 1-pt. can, 25 cts.; 1 -qt. can, 50 cts.

Bordeaux Mixture and Paris Green Compound. The added paris green destroys also plant-eating pests. 1-lb. carton, $35 \mathrm{cts}$

Bug and Blight Dust, No. 3. A powder prepared especially for potato-bugs. 2-lb. carton, $50 \mathrm{cts}$.

Carbon Disulphide. A very effective ant-exterminator. Also for root aphis and all insects infesting the soil. 1-lb. can, 50 cts.

Fish-Oil Soap. An excellent wash for trees and plants where insects affect the bark. 1-Ib. carton, 25 cts.

Hellebore (Powdered White). For currant worms. 1/4-Ib. carton, 10c.; 1/2-Ib. carton, 20c.; 1-Ib. carton, 35c.

Kerosene Emulsion. For aII insects that suck the foliage and stems. 1-pt. can, 20 cts.; 1 -qt. can, 35 cts. Lime-Sulphur. For San José and all other scale. Should be used early in the season as a preventive and is valuable as a summer spray for all perennials and fruit trees. 1-pt. can, 20 cts.

Nicoticide. A strong nicotine solution. For plant-lice, aphis, green fly, etc. 1-oz. bottle, 25 cts.; 2 -oz. bottle, 50 cts.; 4-oz. can, 70 cts.; $1 / 2$-pt. can, $\$ 1.25$.

Tobacco Soap. The best insecticide for house plants during the winter. 1/2-Ib. carton, $20 \mathrm{cts}$.

Slug-Shot. A powder ready for use, for worms on cabbage, currants, cucumbers, etc. 1-lb. carton, 15c.

Mole and Gopher Exterminator. A cartridge of slow action. Use two cartridges; the fumes will quickly kill. 2 cartridges, 25 cts.; 10 for $\$ 1.25$.

\section{WEED-KILLERS}

Herbicide. The weed-exterminator. Saves time and Iabor and keeps roads, gutters, tennis-courts, and walks in the garden free from all weeds and grass. 1 -qt. can, 50 cts.; 1-gal. can, $\$ 1.50$.

Knoxweed. Kills dandelions and other noxious weeds in the lawn. Does not injure the grass, when properly applied. Can, with dropper, containing enough to treat a medium-sized Iawn, 50 cts. 1/2-gal. can, \$1.50; 1 -gal. can, $\$ 2.50$. 


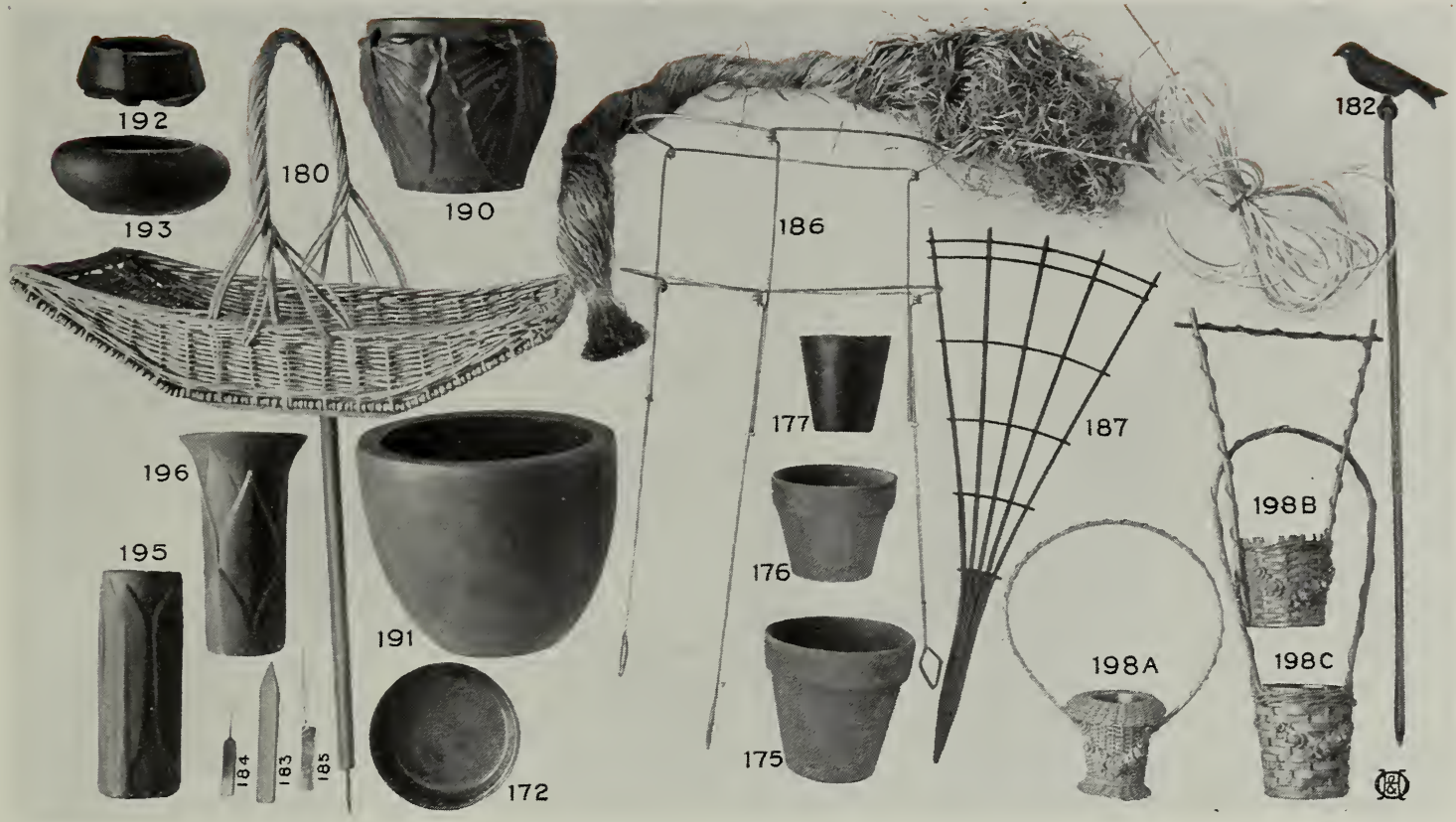

\section{REQUISITES}

FIBER SAUCERS for plants. No. 172. Each, 6 inch 20 cts., 8 inch 25 cts., 10 inch 30 cts.

FLOWER-POTS. No. 175 Standard. Each

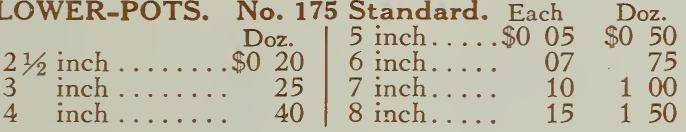

BULB PANS. No. 176. 3/4-size, which are shallow. Price same as standards from 5 inches up.

Pierce Paper Pots. No. 177. Do not come apart.

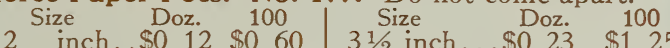

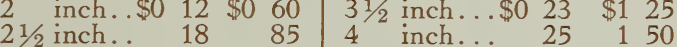

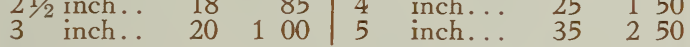

GARDEN BASKETS. For flower-gathering, or workbaskets. Heavy willow. The spike adds to the convenience as the basket can be set anywhere. Each No. 180 A. Green.

No. 180 B. Natural. GARDEN STAKES-

Light Bamboo Canes, Dyed Green. Very strong. Length Doz. 100 Length Doz 100 \begin{tabular}{ll|llll}
12 & in.... \$0 15 & $\$ 075$ & 24 in....... \$0 20 & $\$ 1$ & 15
\end{tabular}

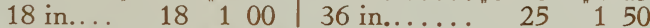

Light Bamboo Canes. Natural. 3 feet.................... $20 \quad 125$ 5 to 6 feet....................... $50 \quad 250$

Heavy Bamboo Canes. Natural.

6 to 8 feet.................. 1251000

GARDEN STICKS-Colored. Will last for years.

No. 182 A. With fancy wood birds. \$1 each.

No. 182 B. With fancy metal birds. \$2 each.

No. 182 C. With fancy pottery birds. \$4 each.

LABELS for Seeds and Plants. Doz. 100 No. 183. 8-in. wooden smooth labels. \$0 $15 \quad \$ 100$ No. 184. 31/2-in. copper-wired wooden. 50 No. 185. 3 $1 \frac{1}{2}$-in. indestructible copper. $35 \quad 275$

TOMATO or PEONY SUPPORTS, No. 186 . Adjustable, heavy, galvanized wire. $30 \mathrm{cts}$. each, $\$ 3.50$ per doz.

TRELLIS, No. 187. Wood, fan-shaped.

24 inch.......\$0 $30 \quad 4$ feet by 27 inches. $\$ 085$ 30 inch............ $45 \quad 5$ feet by 32 inches. 100 36 inch........... $60 \quad 6$ feet by 38 inches. 125 42 inch.......... $70 \quad 7$ feet by 42 inches. 150
POTTERY VASES, JARDINIERES, Etc.

No. 190, Matt-Green Jardinieres. Pretty design and practical shape.

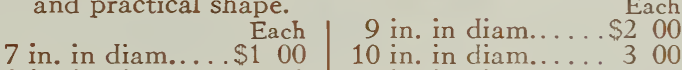

8 in. in diam..... $150 \mid 12$ in. in diam..... 500

No. 191, Cornelian-Green Jardinieres.

7 in., inside diam.\$1 $75 \mid 10$ in., inside diam.. \$4 00

8 in., inside diam. $225 \quad 12$ in., inside diam.. 550

9 in., inside diam. $275 \quad 14$ in., inside diam.. 800

No. 192, Matt-Green Fern Dishes.

5 in. in diam....\$0 $75 \mid 7$ in. in diam..... 200

6 in. in diam.... $100 \quad 8$ in. in diam...... 300

No. 193, Green Flower-Bowls.

5 inches in diameter................. 75

6 inches in diameter................. 100

VELMOS GREEN VASE. Durable and practical

pottery.

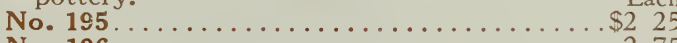

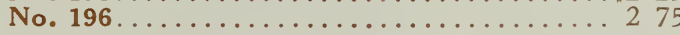

GLASS FLOWER BLOCK, No. 197. Each flower

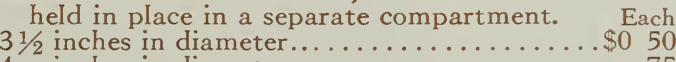

4 inches in diameter.

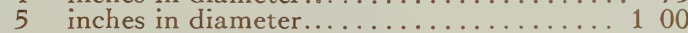

BASKETS FOR FLOWERS. Made of wicker and decorated in gold. Water container included.

No. $198 \mathrm{~A}, \mathrm{~B}, \mathrm{C}$. $\$ 1.65$ each, or the three for $\$ 4.25$. REEDS or RATTAN, for basket-making. Imported round reeds of the best quality. Sample card mailed on request.

No. Lb. $1 / 2 \mathrm{lb}$. Bunch $\begin{array}{lllllllllllllll}1 & . . \$ 1 & 75 & \$ 0 & 90 & \$ 0 & 25 & 5 \ldots . . \$ 1 & 15 & \$ 0 & 60 & \$ 0 & 25 \\ 2 & 1 & 50 & 80 & 25 & 6 & \ldots & 1 & 00 & & 55 & & 25\end{array}$

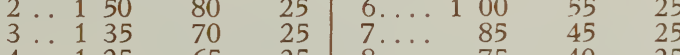

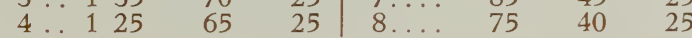

RAFFIA FOR BASKET-MAKING, TYING PLANTS, etc. We have forty different shades. Lb. 85 cts., $1 / 2$ lb. 45 cts., large bunch 10 cts.

Naturai Raffia. Lb. 50 cts., 1/2lb. 30 cts., bunch 10c.

Raffia Needles. 10 cts. per doz.

BOOKS ON BASKET-MAKING.

Basket-Making. Well illustrated. 25 cts. each.

The Basketry Book. By Mary Miles Blanchard. $\$ 2.50$ each. 


\section{INDEX TO DEPARTMENTS}

Cut-Flowers

EVERGREENS.

Fruit DepartMent.

Hedges, Deciduous

Hedges, Evergreen.

Lawn and Garden Furniture and

SETIINGS....

PAGE
76,77
$18-23$
$69-75$
$41-47$
$\ldots \ldots 47$
$.72-84$

Lawn and Garden Tools. .

LAwN SEED...

Perennials...

Planning Your
Plants, Bedding

Plants, Decorative.
PAGE
$.92-97$

$.90,91$

48-63

86,87

$.78-81$
Roses.

Shrubs, D............... 64-68 TREES A ECIDUOUS . ............. $24-37$ . Trees, Ornamental.......... 5-15 TEES, WEEPING............ 16, 17

Vines and CREePERS...........40 40.43

\section{GENERAL INDEX}

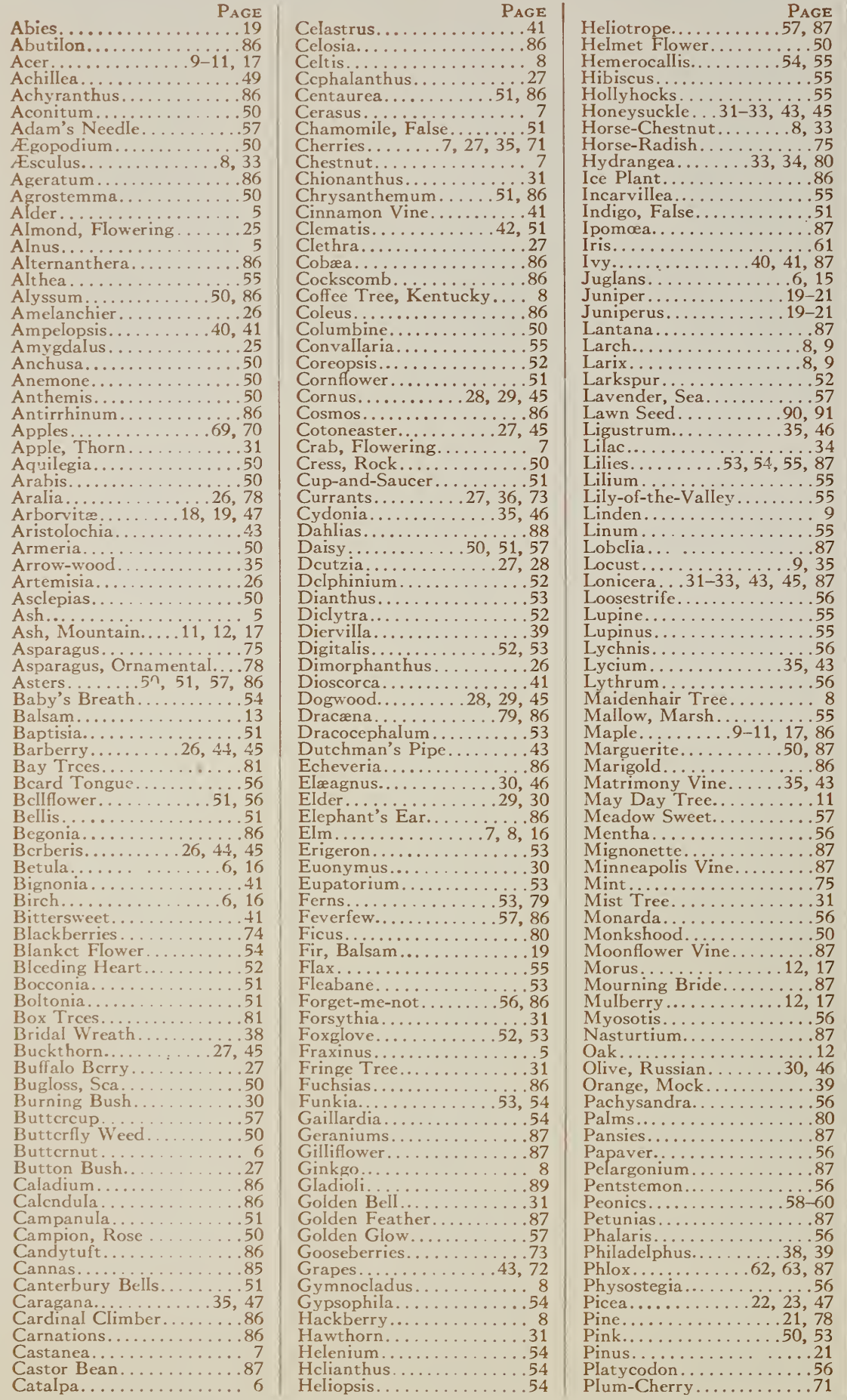

Plums.......13,35,70,71

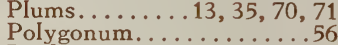
Poplar...............13, 14 Poppy............. 51, 56 Potentilila..................... Privet................. 35,46 Prunus............... Pseudotsuga............. 23

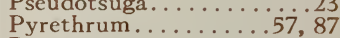
Pyrethrum................. 7,35 Quamoclit............... 86 Quercus............... Ranunculus..............57 Raspberries...............74 Rhamnus.........27, 45 Rhubarb........14, 15, 3i, 38 Rhus.........14, 15, 31, 38

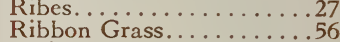
Ricinus............... 87 Robinia............9, 35 Roses.............46, 64-68 Rudbeckia................57 Salisburia................. 8 Salix............... 15, 17, 47 Salpiglossis............. 57,87 Salvia.............. 57, 87
Sambucus..........29, 30 Scabiosa.................. 87 Sedum. . . .

Shepherdia................27

Snapdragon................ 86

Sneezewort............. 54

Snowball................ 35,36

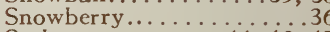
Sorbus.........11, 12, 17 Spearmint ............5 56 Speedwell............ $36-38$ Spiræa.........36-38, 46, 5

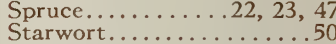
Statice...................... Stock ..................... 87 Stokesia.................... 57 Stonecrop.............. 57 Strawberries........ 14,75 Sumac...........14, 15, 38 Sunflower .............. 54 Symphoricarpcs..............36 Syringa..........34, 38, 39 Tamarix................ 38, 39

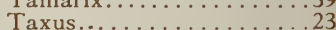
Thuxus............... 19,23 Tilia.................. 9 Tradescantia............87 Trumpet Vine, Scarlet...... Ulmus............... $7,8,16$ Valeriana................. 57 Vegetablc Roots.............75 Verbenas................. 87 Veronica................... 57 Viburnum.............35, 36 Vinca............... 87 Viola................57 Violets.............. . 57 Virginia Creeper..........41 Vitis................... Walnut ..................... 87 Wandering Jew..........8. Wayfaring Tree..........35

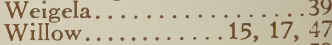
Windflower................. 50 Wistaria .............. 43 Yew...............23 Zinnias.................. 

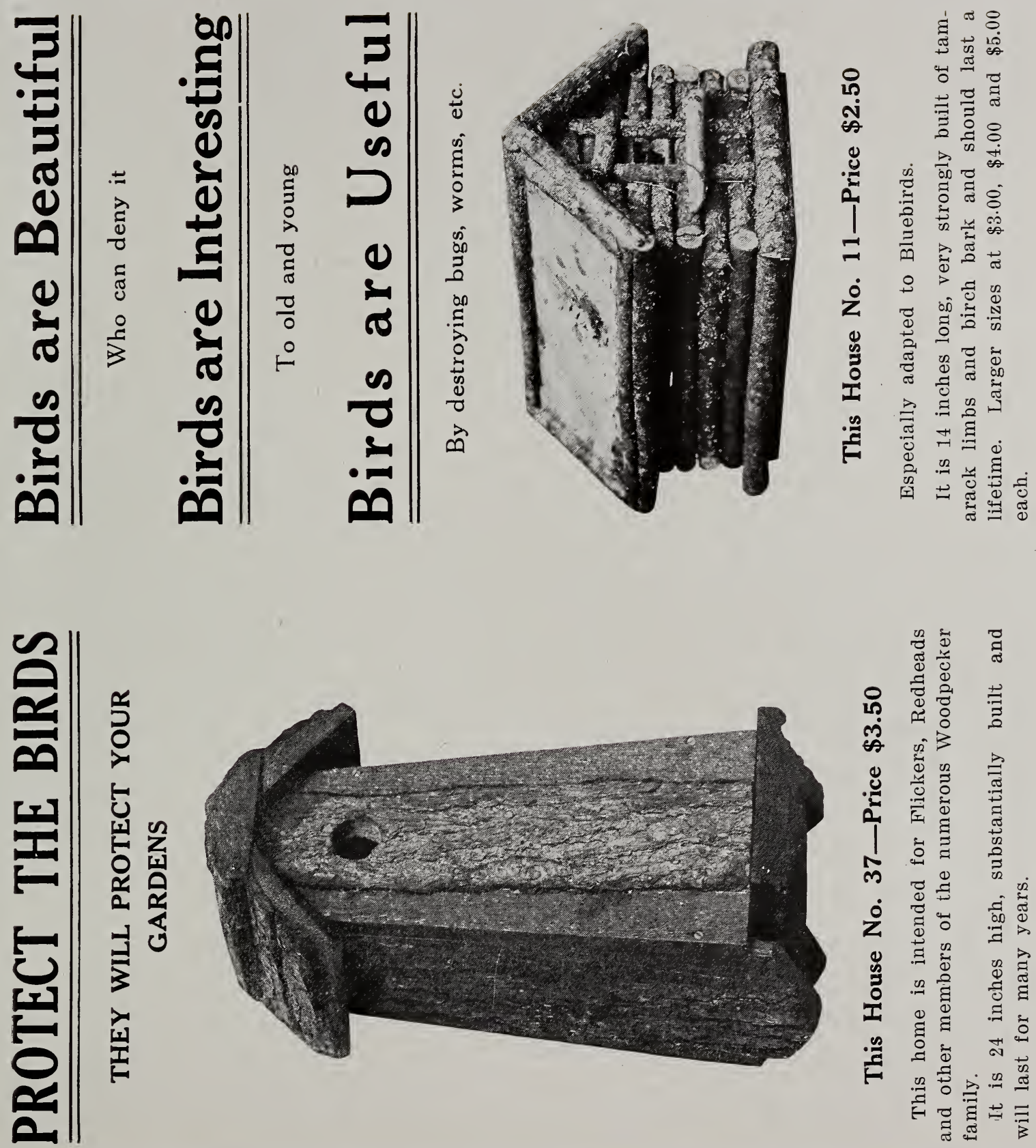

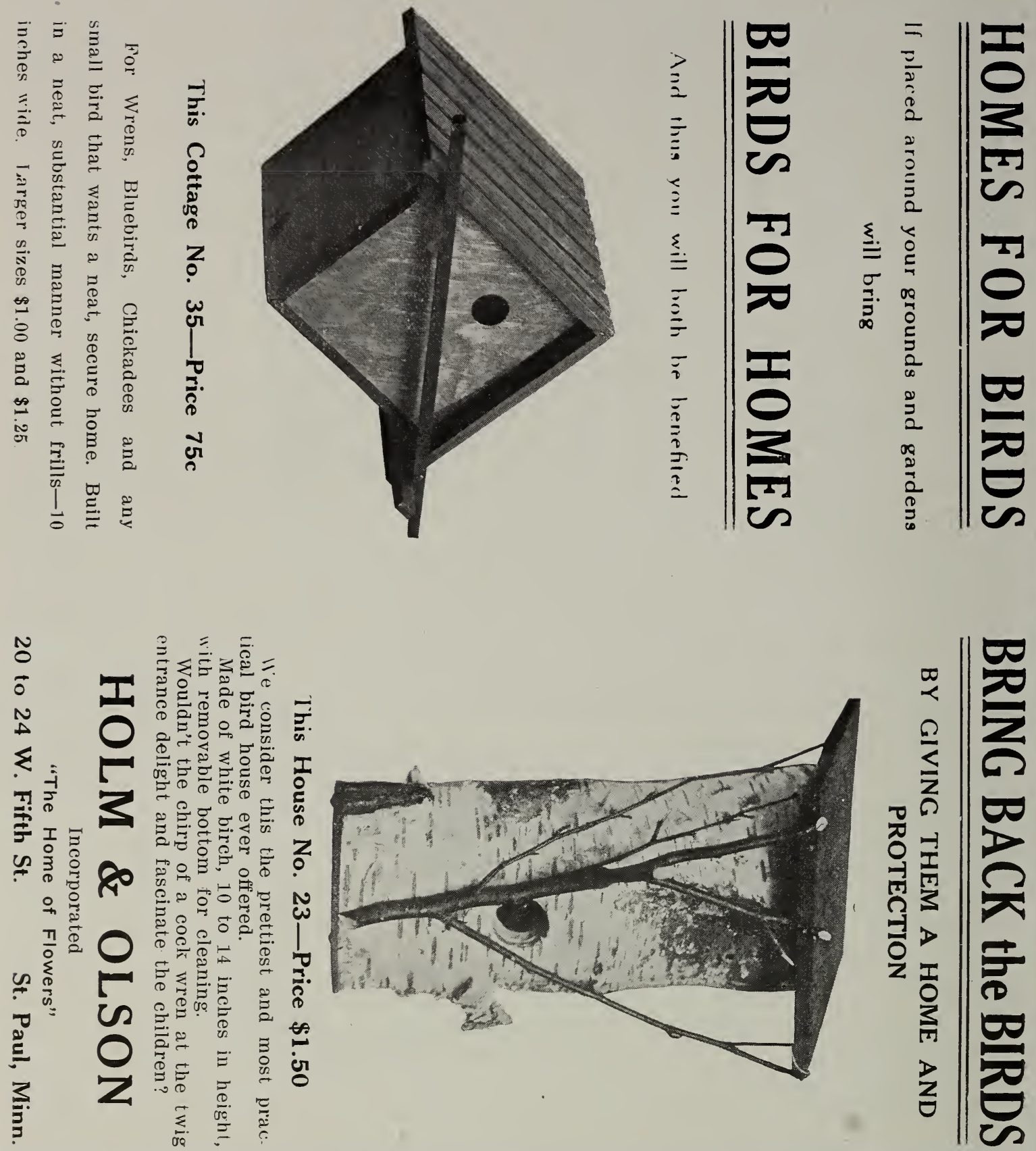


\section{ORDER SHEET}

HOLM \& OLSON, Inc., St. Paul, Minn.

Gentlemen: Enclosed find Cash Registered Letter . . \$

$\begin{array}{lll}\text { “ } \quad \text { Draft } & . \\ \text { “ } & \text {. P. O. or Express Money Order. }\end{array}$

Name

Post Office

Rural Route

County

state

Express Office

Railroad Station

Forlvard About

Our booklet, "The Essential Principles of Lawn Making," tells you how to make a good Lawn, and what seed to sow for best results. Sent only on application.

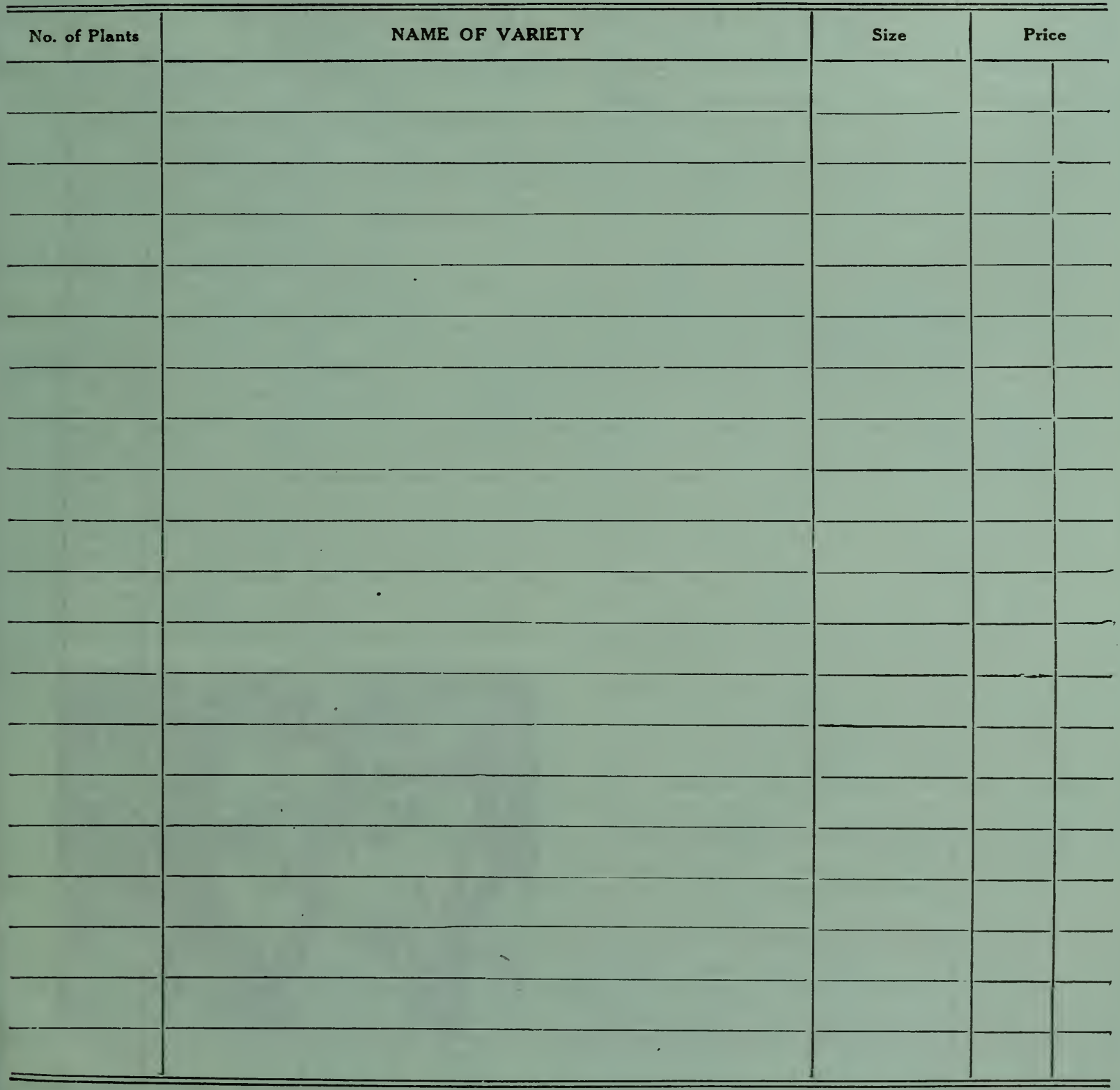


Have you ever used the H. \& O. Service? If not, let's get better acquainted

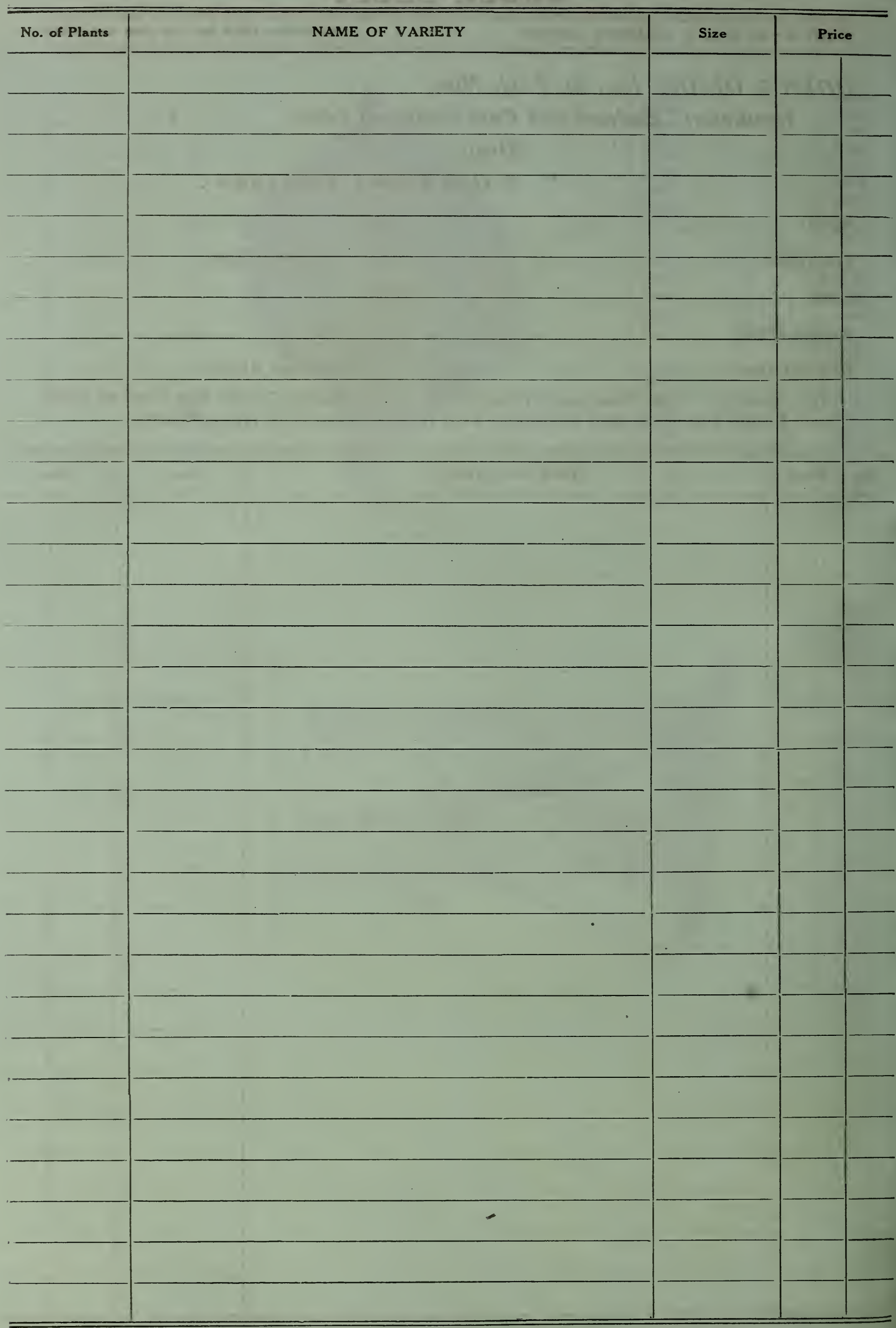



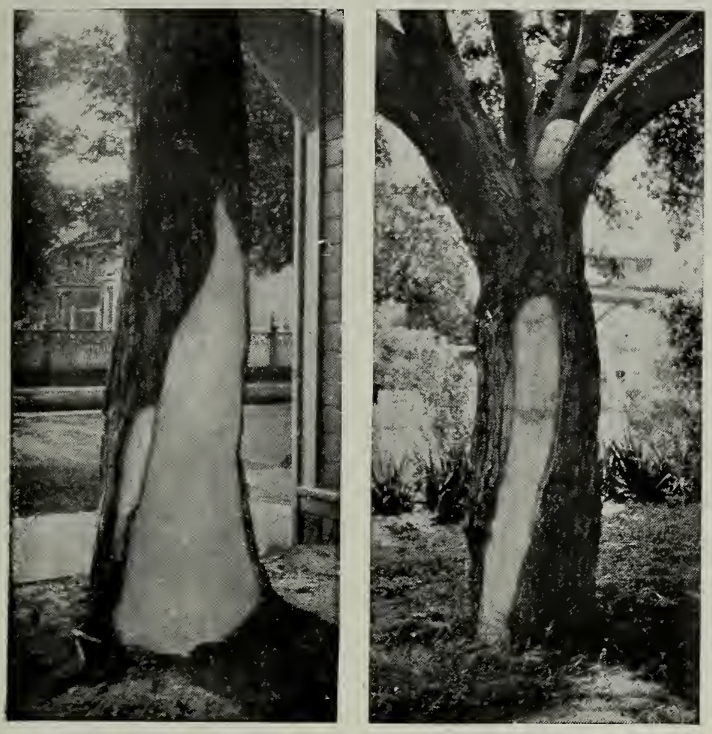

Careful treatment of a badly decayed trunk

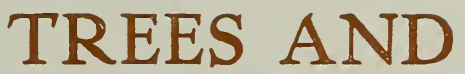

Why Trees Should be Pruned. There is a logical and scientific reason why the $\operatorname{limb}$ of a tree should be removed, or why it should remain.

Trees need pruning to keep them healthy; diseased and decayed limbs should be removed before they cause greater damage. Trees often need thinning, removing branches that cross, so that decay will not start and leave wounds that later on injure the trees. Trees need pruning to keep them symmetrical so their top may be evenly balanced, thus making them into things of beauty.

Not all trees grow straight or beautiful, but they may be kept shapely and healthy provided they receive the attention of one who knows their habits, who has made a study of tree life, and knows the treatment they should receive.

Treating the Cavity. Possibly in years past the wind may have broken off some limbs, or some person who did not know how to prune cut the limbs improperly and did not treat the wound. Under such conditions decay soon started and continued from year to year until a large cavity is the result. Treating such a cavity requires knowledge as well as practical experience. AII the decayed and diseased wood must be removed and the healthy wood treated chemically so that all fungi may be removed, the sound wood preserved and the wound kept from "bleeding," or oozing of the sap, Filling the cavity with cement is only the mechanical part-

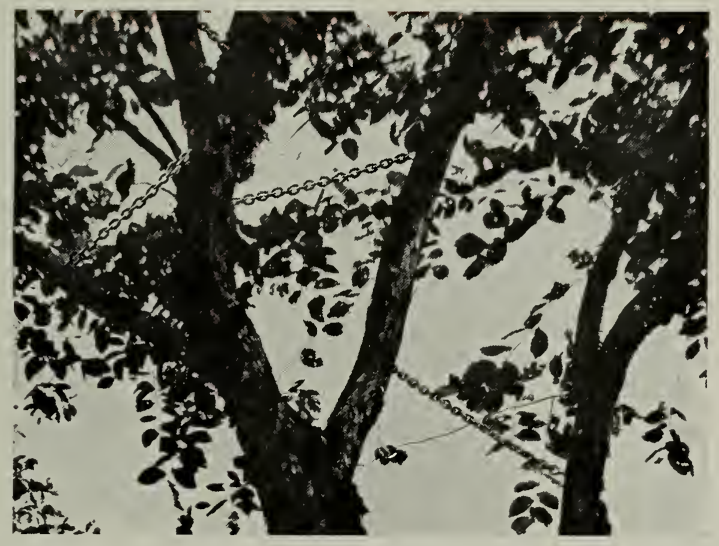

Showing the proper way of adjusting cbains

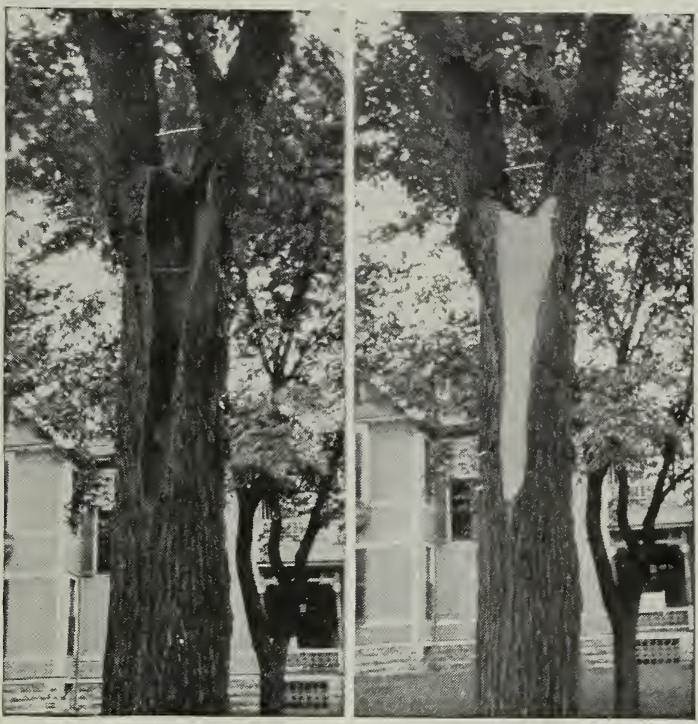

How our experts saved the old tree

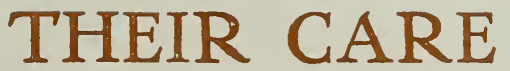

the expert work must be done before this operation is undertaken.

Bracing and Bolting. An expert landscape man will never plant a tree with a crotch, for he knows that it will produce trouble in the future. Trees that have been properly grown in the nursery row do not have crotches, therefore this defect is usually found in trees that have been secured in the woods. Such trees must be saved from splitting by the use of bolts, or bolts and chain. Never allow a band, chain or wire to be placed around the trunk or limbs; this stops or checks the flow of sap and injures the tree. If the bolts and rods are properly placed, the trees can be kept in good condition for years.

Fertilizing and Mulching. Many trees are planted in poor soil, without any thought of their future development; the result is that disease and decay have come because the tree has been starved, and the older and Iarger the tree the more quickly it shows these ill effects. To restore the lost vitality, fertilizer must be supplied, and in such form that the small roots will gather the plant-food and carry and distribute it to the entire tree. If your trees are not in a healthy condition, write us, giving us the details, and we will endeavor to assist you.

Inspection. It is entirely possible that your trees may need an inspection by one of our experts. Our landscape men are always on the road, and one of them may be in your neighborhood or close by; the cost of such an inspection would be slight.

Costs. We charge you a stipulated price per day for the man, plus the expenses. This price may vary a little, for it is governed by the ability of the men, the season in which the work is to be done, and the character of the work. We shall be pleased to give you an estimate on the work, or advise with you relative to the best manner in which to handle it.

The H. \& O. Service. Our Service assures you perfect satisfaction, for we employ men who are above the average of their class. We are planning, designing and planting grounds over the entire Northwest. We limit our territory so that we may be able to give the best service possible, grow everything we plant or recommend for planting, and grow this better than anyone else. "H. \& O. Service" stands for quality, and this service, like "H. \& O. Quality," is the best money can buy. We shall be pleased to refer you to some of our patrons in your neighborhood or give you any other references. 


\section{Complete Landscape Service}

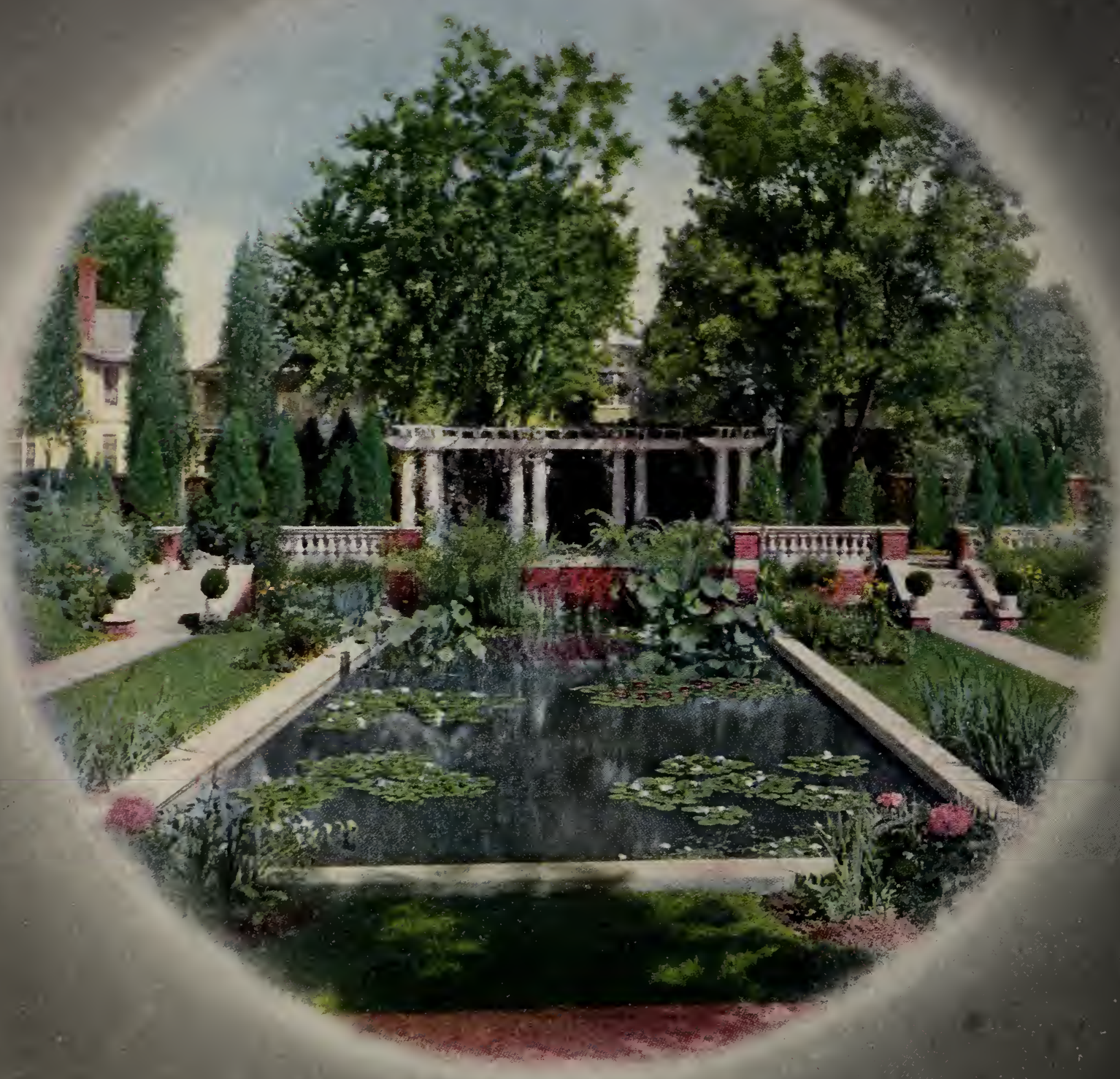

Holm Olson INCORPORATED The Park Nurseries Saint Paul, Minnesota 